Food Safety and Quality Standards in the Thai Horticultural Sector:

\author{
Implications for Small-Scale Farmers
}

\begin{abstract}
Dissertation
to obtain the $\mathrm{Ph}$. D. degree

in the International Ph. D. Program for Agricultural Sciences in Goettingen (IPAG)

at the Faculty of Agricultural Sciences,

Georg-August-University Göttingen, Germany

presented by

Sarah Kersting

born in Dortmund
\end{abstract}

Göttingen,

December 2012 
D7

1. Name of supervisor: Prof. Dr. Meike Wollni

2. Name of co-supervisor: Prof. Dr. Matin Qaim

Date of dissertation: 15.02.201 


\section{Summary}

The growth of the agricultural sector is crucial to reduce poverty in developing countries. Poverty is still a mainly rural phenomenon and more than two thirds of the world's poor continue to live in rural areas, most of them relying on agriculture as the main income source. The enhanced participation of small-scale farmers in the growing global market for highvalue agricultural products, such as livestock products, fish and fresh fruit and vegetables is seen as one of the most promising ways to reduce poverty. In particular, the diversification into horticulture offers many opportunities for small-scale farmers. Compared to the production of staple crops, fruit and vegetables cultivation is labor intensive, generates higher levels of employment and higher net incomes per hectare. However, the market access of smallholders to high-value supply chains is increasingly threatened by a tightening and proliferation of public and private food safety and quality standards. While public standards have long been recognized as an important barrier to exports from developing to developed countries, private standards, although voluntary are becoming a requirement to access highvalue markets worldwide.

In this study, we focus on the implications of the GlobalGAP standard for small-scale fruit and vegetable farmers in developing countries. GlobalGAP was developed by a group of European retailers in 1997 with the aim to harmonize retailers' existing standards and today is the most widely used private certification scheme for good agricultural practices. The increasing importance of the GlobalGAP standard offers new challenges as well as new opportunities for smallholders in developing countries. On the one hand, several studies have shown that complying with GlobalGAP is especially difficult for small-scale farmers due to the high costs of compliance and the high technical and managerial requirements of the standard. On the other hand, the standard may have a positive impact on the livelihoods of farmers who are able to comply. Amongst others, GlobalGAP adoption is discussed to lead to higher and more stable incomes and thus to a reduction of poverty and vulnerability. However, besides the challenge to overcome the initial barriers to standard adoption, there is increasing evidence that continuously meeting the strict requirements and high costs associated with GlobalGAP is challenging for smallholders. In particular, several studies report that donor facilitated GlobalGAP adoption is often not sustainable and that farmers abandon the standard following the withdrawal of donors. 
Given the potential challenges and opportunities associated with the GlobalGAP standard, this study aims to identify mechanisms that enable small-scale farmers to sustainably adopt the GlobalGAP standard and to benefit from certification. More specifically, the following three objectives are addressed in this study. First, we identify the factors that influence GlobalGAP adoption, taking into account the support by donors, public-private partnerships and exporters. Second, we analyze the impacts of GlobalGAP certification on producer prices and on farmers' net household income. Third, the determinants of continued compliance with GlobalGAP following the withdrawal of donor support are investigated.

The empirical analyses are based on a panel data set of Thai fruit and vegetable farmers which we collected in 2010 and 2011. For the purpose of our study, the relevant population of Thai fruit and vegetable farmers was stratified according to participation in a development program which aimed to enable small-scale farmers to adopt the GlobalGAP standard. The program was carried out between 2008 and 2010 and within the first half of 2010 several of the participants successfully obtained a GlobalGAP certificate. During the first survey in 2010, we interviewed 287 farm households, whereas 146 are program participants and 141 are nonparticipants. To some extent sample attrition occurred in 2011 and 218 of the 287 households were interviewed a second time.

In the first part of our analysis, we compare different institutional arrangements that can be formed under GlobalGAP group certification and analyze the factors influencing GlobalGAP adoption. The analysis is based on the cross-sectional data set that we collected in 2010 and thus corresponds to the period before GlobalGAP adoption for certified farmers in our sample. In our research area, the increasing demand for GlobalGAP has encouraged the formation of new institutional arrangements between donors, exporters and farmers. Farmers participating in a development program were organized in certification groups with either a donor-run, farmer-run or exporter-run Quality Management System. The results of our adoption analysis show that the support by donors, exporters and public-private partnerships is critical to enable small-scale farmers with limited human, social and physical capital to adopt the GlobalGAP standard. Furthermore, we find that GlobalGAP adoption is influenced by household and farm characteristics, such as education, the availability of family labor, the use of efficient irrigation systems, and previous experience in high-value supply chains.

In addition, the impacts of GlobalGAP certification on fruit and vegetable producer prices and on farmers' net household income are analyzed. The availability of panel data allows us to use the fixed effects approach which controls for time-invariant unobserved heterogeneity across 
households. Besides estimating average treatment effects of certification, we are interested in whether the impact of GlobalGAP certification differs between subgroups of adopters, i.e., between farmers certified in exporter-managed and producer-managed groups and between smaller and larger farmers. We find that, on the average, GlobalGAP certification has a large and significant positive effect on prices and on net household income. The high average effect, however, is mainly driven by large significant positive effects in the producer-managed groups, in which GlobalGAP certification resulted in on the average 62\% higher prices and 14,678 USD higher net household incomes. In the exporter-managed groups, in contrast, we cannot identify a significant impact of certification. Moreover, we find that larger farmers in producer-managed certification groups realize high net income gains while smaller farmers only benefit as long as they do not have to incur recurrent costs of compliance, i.e., as long as they receive financial support by a donor.

The last part of our study deals with the sustainability of donor supported GlobalGAP adoption. A bivariate probit model is estimated to analyze the determinants of GlobalGAP recertification conditional on initial adoption of the standard. The results show that the support by an exporter in terms of financial, technical and managerial assistance is the most important determinant of continued compliance with GlobalGAP and increases the probability to become re-certified by $85 \%$. This finding indicates that although farmers in producermanaged certification groups on the average benefit from certification, they are usually not capable to become re-certified when donor support is not available. Moreover, we find that larger farmers and farmers with a higher share of the total land certified are more likely to obtain a renewal of the certificate. Hence, we can conclude that relatively small and less integrated farmers are the first to disadopt the GlobalGAP standard when donor support ends. These farmers, however, were most at risk to lose access to high-value markets as a consequence of increasing food safety and quality requirements and were therefore primarily targeted by development programs. 


\section{Zusammenfassung}

Das Wachstum des Agrarsektors ist einer der entscheidenden Faktoren, um Armut in Entwicklungsländern zu verringern, da Armut auch heute noch ein vor allem ländliches Phänomen ist. Zwei Drittel der Armen weltweit leben auf dem Land und sind in der Mehrzahl direkt oder indirekt von der Landwirtschaft abhängig. Die verstärkte Teilnahme von Kleinbauern am wachsenden globalen Markt für hochwertige Nahrungsmittel wie tierische Erzeugnisse, Fisch, Obst und Gemüse wird als eine der vielversprechendsten Möglichkeiten gesehen, um Armut zu reduzieren. Insbesondere die Verbreitung des Obst- und Gemüseanbaus bietet eine Vielzahl von Chancen für Kleinbauern, da dieser im Vergleich zum Anbau von Grundnahrungsmitteln einen höheren Arbeitseinsatz erfordert sowie höhere Einkommen pro Hektar generiert. Die Ausschöpfung der sich eröffnenden Möglichkeiten kann jedoch durch die wachsende Bedeutung von privaten und öffentlichen Lebensmittelsicherheits- und Qualitätsstandards behindert werden. Während öffentliche Standards schon lange als ein Handelshemmnis für Exporte von Entwicklungsländern in Industrieländer gelten, werden private, vom Einzelhandel festgelegte Standards zunehmend zu einem Erfordernis, um Zugang zu Märkten weltweit zu erhalten.

In dieser Studie befassen wir uns mit den Auswirkungen des GlobalGAP Standards auf Obstund Gemüsekleinbauern in Entwicklungsländern. Der GlobalGAP Standard wurde 1997 durch europäische Einzelhandelsunternehmen mit dem Ziel entwickelt, die sehr unterschiedlichen Qualitätsstandards der einzelnen Unternehmen zu harmonisieren, und gilt heute als der wichtigste Standard für gute Agrarpraxis weltweit. Während die steigende Bedeutung des GlobalGAP Standards Kleinbauern in Entwicklungsländern vor neue Herausforderungen stellt, bietet diese gleichzeitig auch neue Chancen. Verschiedene Studien haben gezeigt, dass die Implementierung des GlobalGAP Standards für Kleinbauern aufgrund von hohen Investitionskosten sowie hohen technischen und administrativen Erfordernissen mit besonders großen Schwierigkeiten verbunden ist. Auf der anderen Seite wird diskutiert, dass eine erfolgreiche Annahme des Standards zu stabileren und höheren Einkommen führen kann und somit zu einer Verringerung von Armut und Vulnerabilität beitragen kann. Jedoch ist nicht nur die Implementierung des GlobalGAP Standards eine große Herausforderung für Kleinbauern in Entwicklungsländern, sondern die ständige Einhaltung des Standards gestaltet sich häufig aufgrund der hohen laufenden Kosten und der strengen Erfordernisse des Standards als ebenso schwierig. Verschiedene Studien haben gezeigt, dass insbesondere die Kleinbauern, die mit Unterstützung von Entwicklungshilfsprogrammen ein GlobalGAP 
Zertifikat erhalten haben, vielfach nicht dazu in der Lage sind, den Standard selbständig aufrechtzuhalten.

Auf Grundlage der oben beschriebenen Chancen und Herausforderungen, die der GlobalGAP Standard mit sich bringt, ist es das Ziel dieser Studie, Mechanismen zu identifizieren, die Kleinbauern dazu in die Lage versetzen, den GlobalGAP Standard nachhaltig anzunehmen, um langfristig von einer Zertifizierung zu profitieren. Hierzu werden zunächst die Faktoren, die die Annahme des GlobalGAP Standards beeinflussen, identifiziert, wobei die Unterstützung von Gebern, öffentlich-privaten Partnerschaften und Exporteuren mit einbezogen wird. Darauf folgend analysieren wir die Auswirkungen der GlobalGAP Zertifizierung auf Produzentenpreise für Obst und Gemüse und auf das NettoHaushaltseinkommen der Landwirte. Zuletzt werden die Determinanten der GlobalGAP Rezertifizierung nach Ende der Unterstützung durch Entwicklungshilfsprogramme untersucht.

Die empirische Analyse basiert auf einem umfangreichen Paneldatensatz von thailändischen Obst- und Gemüsebauern, der in den Jahren 2010 und 2011 erhoben wurde. Die Grundgesamtheit von Obst- und Gemüsebauern wurde nach der Teilnahme an einem Entwicklungshilfsprogramm stratifiziert, welches zum Ziel hatte, thailändische Kleinbauern in der Annahme des GlobalGAP Standards zu unterstützen. Das Programm wurde zwischen 2008 und 2010 durchgeführt und zu Beginn des Jahres 2010 konnte eine Vielzahl von Programmteilnehmern erfolgreich das GlobalGAP Zertifikat erlangen. Während der ersten Befragungsrunde im Jahr 2010 wurden 287 Haushalte interviewt, davon sind 146 Teilnehmer des Entwicklungshilfsprogramms und 141 sind Nicht-Teilnehmer. Im Jahr 2011 konnten 218 der 287 Haushalte ein zweites Mal interviewt werden.

Im ersten Teil der Studie vergleichen wir verschiedene institutionelle Arrangements, die unter die GlobalGAP Gruppenzertifizierung fallen, und analysieren die Faktoren, die die Annahme des GlobalGAP Standards bedingen. Die Analyse basiert auf den im Jahr 2010 während der ersten Befragungsrunde erhobenen Querschnittsdaten, die die Situation der Haushalte vor der Zertifizierung widerspiegeln. In unserer Forschungsregion hat die vermehrte Nachfrage nach GlobalGAP zertifizierten Produkten zu der Bildung neuer institutioneller Arrangements zwischen Gebern, Exporteuren und Landwirten geführt. Teilnehmende Landwirte an einem Entwicklungshilfsprogramm wurden in verschiedenen Zertifizierungsgruppen organisiert, die sich im Hinblick auf das Management des internen Kontrollsystems unterscheiden. Dieses kann entweder durch Geber, Exporteure oder durch die Landwirte selbst geleitet werden. Die Ergebnisse unserer Analyse zeigen, dass die Unterstützung durch 
Entwicklungshilfsprogramme, Exporteure und öffentlich-private Partnerschaften entscheidend ist, um Kleinbauern mit einem geringen Human- und Sozialkapital sowie mit geringen finanziellen Ressourcen die Annahme des GlobalGAP Standards zu ermöglichen. Zudem wird die Annahme der GlobalGAP Standards durch Haushalts- und Betriebsmerkmale wie Bildung, die Verfügbarkeit von Arbeitskräften in der Familie, die Nutzung effizienter Bewässerungstechniken sowie vorherige Erfahrung in modernen Wertschöpfungsketten beeinflusst.

Des Weiteren analysieren wir die Auswirkungen der GlobalGAP Zertifizierung auf Obst- und Gemüseproduzentenpreise sowie auf das Netto-Haushaltseinkommen von Landwirten. Die Analyse beruht auf den erhobenen Paneldaten, die es uns ermöglichen, das Fixed-EffectsModell anzuwenden, welches für einen Selektionsbias aufgrund von zeitkonstanter, unbeobachtbarer Heterogenität kontrolliert. Neben der Schätzung von durchschnittlichen Effekten der GlobalGAP Zertifizierung untersuchen wir die Frage, ob sich die Auswirkungen von GlobalGAP zwischen Untergruppen zertifizierter Landwirte unterscheiden. Für die Studie differenzieren wir zwischen zertifizierten Landwirten, die in von den Produzenten selbst oder in von Exporteuren geführten Gruppen organisiert sind, sowie zwischen Landwirten mit einer größeren oder kleineren zertifizierten Fläche. Die Ergebnisse zeigen, dass eine GlobalGAP Zertifizierung im Durchschnitt hohe positive Auswirkungen auf Produzentenpreise sowie auf das Netto-Haushaltseinkommen von Landwirten hat. Der hohe durchschnittliche Effekt wird jedoch vor allem durch hohe positive Auswirkungen in den von Produzenten geführten Gruppen gesteuert. In diesen hat die Annahme des GlobalGAP Standards im Durchschnitt zu 62\% höheren Preisen sowie zu 14,678 USD höheren Netto-Haushaltseinkommen geführt. In den von Exporteuren geleiteten Gruppen kann dagegen kein signifikanter Einfluss der Zertifizierung festgestellt werden. Des Weiteren stellen wir fest, dass die realisierten Einkommenseffekte in den von Produzenten geführten Gruppen von der Größe der zertifizierten Fläche abhängen. Während größere Betriebe sehr hohe Einkommensgewinne erzielen, können kleinere Betriebe nur solange einen signifikanten Effekt verzeichnen, wie sie die wiederkehrenden Kosten der Zertifizierung nicht selbst tragen müssen, d.h. solange sie finanzielle Unterstützung durch einen Geber erhalten.

Der letzte Teil unserer Studie befasst sich mit der Nachhaltigkeit der von Entwicklungshilfsprogrammen unterstützen GlobalGAP Zertifizierung von Kleinbauern. Wir schätzen ein bivariates Probit-Modell, um die Faktoren, die die nachhaltige Annahme des GlobalGAP Standards beeinflussen, in Abhängigkeit von erstmals erfolgter Zertifizierung zu 
analysieren. Die Ergebnisse zeigen, dass die Unterstützung durch Exporteure der weitaus wichtigste Einflussfaktor der ständigen und nachhaltigen Einhaltung des GlobalGAP Standards ist. Im Vergleich zu Landwirten in von Produzenten geführten Gruppen haben Bauern, die in von Exporteuren geleiteten Gruppen organisiert sind, eine 85\% höhere Wahrscheinlichkeit erneut zertifiziert zu werden. Daraus lässt sich schließen, dass die Mehrheit der zertifizierten Bauern in den von Produzenten geleiteten Gruppen nicht die Fähigkeiten besitzt, den GlobalGAP Standard ohne externe Unterstützung dauerhaft aufrecht zu erhalten, obwohl sie im Durchschnitt einen hohen Nutzen aus der Zertifizierung ziehen könnten. Des Weiteren zeigen die Ergebnisse, dass größere Betriebe mit einem höheren Anteil der zertifizierten Fläche an der Gesamtfläche häufiger erneut zertifiziert werden. Somit können wir feststellen, dass die relativ kleinen und weniger integrierten Bauern zu den ersten gehören, die nach dem Ende von Entwicklungshilfsprogrammen den GlobalGAP Standard ablegen. Diese bilden jedoch die primäre Zielgruppe von Entwicklungshilfsprogrammen, da sie am ehesten gefährdet sind, den Zugang zu Märkten aufgrund der steigenden Bedeutung von Lebensmittelsicherheits- und Qualitätsstandards zu verlieren. 


\section{Acknowledgements}

The completion of this dissertation would not have been possible without the support of many people. First of all, I would like to express my deep gratitude to my supervisor Jun.-Prof. Meike Wollni for the outstanding support and guidance she has given me during the years of my dissertation. Her valuable advice and comments as well as the numerous discussions with her have greatly improved my work. I would also like to thank my second supervisor Prof. Matin Qaim for comments on my work, especially during the early phase of my dissertation project. Furthermore, I thank my third supervisor Prof. Achim Spiller, who immediately agreed to be a member of the examination board.

I would like to thank the fiat panis foundation, the German Academic Exchange Service (DAAD) and the Deutsche Gesellschaft für Internationale Zusammenarbeit Thailand (GIZ) for financial support to carry out the field work in Thailand and to present the results of this study at international conferences.

The data collection in Thailand would not have been possible without the close cooperation with the Cluster of Western GAP of Kasetsart University, Kamphaengsaen and the GIZ office in Bangkok. In particular, I would like to thank Dr. Roongnapa Korpraditskul, Dr. Chuanpis Aroonrungsikul and Dr. Chainarong Rattanakreetakul of the Western Cluster GAP for their exceptional support during the field work and their willingness to share their knowledge on GAP in Thailand with me. This work has also greatly benefited from their contacts to different institutions in the Thai F\&V sector, to exporters and to farmer groups. Moreover, my gratitude goes to Wannipa Wattanavaekin and Phitcha Wanitphon of the GIZ office in Bangkok, who were always interested in my study and provided support whenever possible. Furthermore, I would like to thank Gung and Ying from the Cluster of Western GAP office for their administrative support and their always cheerful company in Kamphaengsaen. I am also greatly indebted to Panit Nualchan for her friendship and support during the field work and for introducing me to Thai culture.

Many thanks also go to my enumerators for their assistance and often hard work during the surveys. Moreover, I would also like to thank all interviewed farmers for their willingness to participate in the surveys and for their patience in answering our endless questions. In addition, I would also like to thank the exporters and collectors involved in the GIZ development program for their time and support during the surveys. 
I am also particularly grateful for the company, motivation and support of all my colleagues at the chair of International Agricultural Economics and the chair of International Food Economics and Rural Development during my time in Göttingen. Their comments and suggestions have greatly contributed to my work.

Finally, I would like to express my gratitude to my friends and family, who provided so much support and encouragement during my PhD studies. In particular, I would like to thank Timo Holzapfel for his endless loving support and patience, especially during the long stays in Thailand. I am also very thankful to my parents for their guidance, their interest in my studies and their confidence in me, which has always encouraged me. 


\section{Table of contents}

Summary ............................................................................................................................................... III

Zusammenfassung ............................................................................................................................VI

Acknowledgements............................................................................................................ X

Table of contents............................................................................................................................... XII

List of tables ................................................................................................................................. XV

List of figures ..............................................................................................................................XVI

List of abbreviations........................................................................................................... XII

1. General introduction .....................................................................................................1

1.1. The role of high-value agriculture in rural poverty alleviation....................................... 1

1.2. Public and private food safety and quality standards.................................................... 3

1.2.1. Understanding the rise of private food safety standards ....................................... 3

1.2.2. The case of the GlobalGAP standard ................................................................ 5

1.2.3. Implications of standards for small-scale farmers in developing countries ............. 6

1.2.4. The role of standards in the Thai fruit and vegetable sector .................................. 8

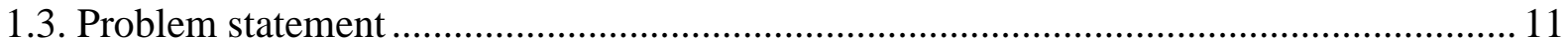

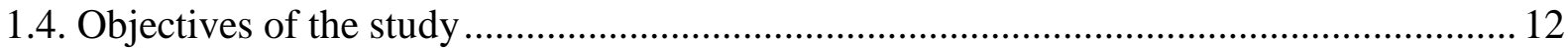

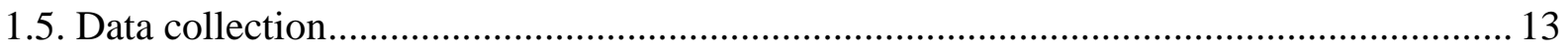

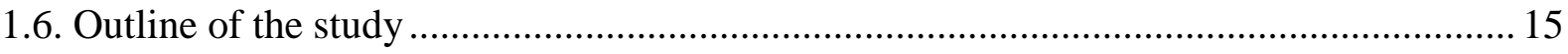

2. New institutional arrangements and standard adoption: Evidence from small-scale fruit and vegetable farmers in Thailand ......................................................................... 17

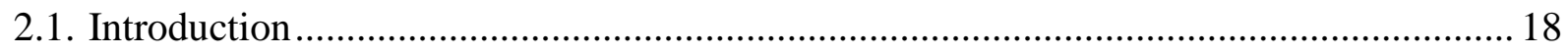

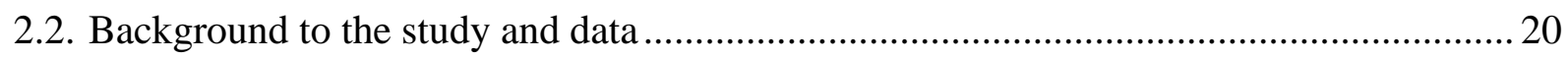

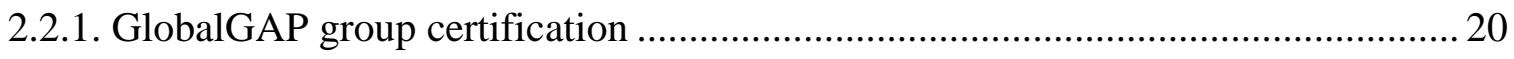

2.2.2. New institutional arrangements and standards in the Thai FFV sector................... 21

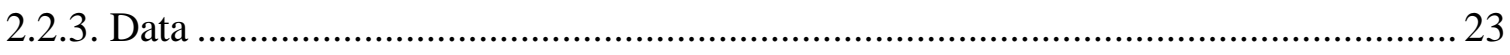

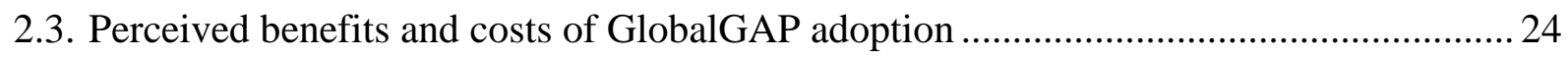




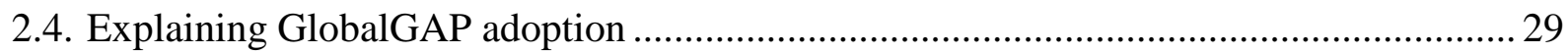

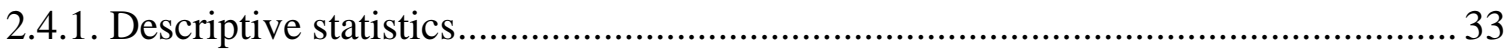

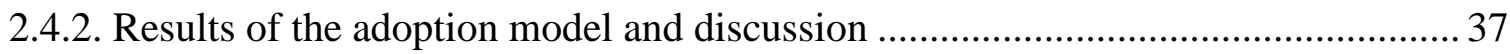

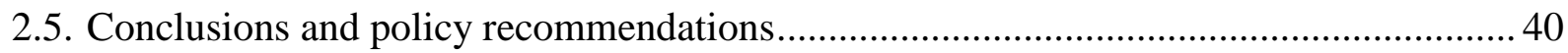

3. Innovative business models in the Thai horticultural sector: A panel data analysis of the impacts of GlobalGAP certification .................................................................................. 43

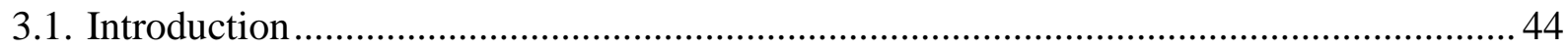

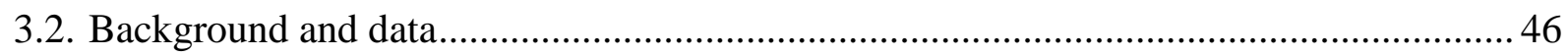

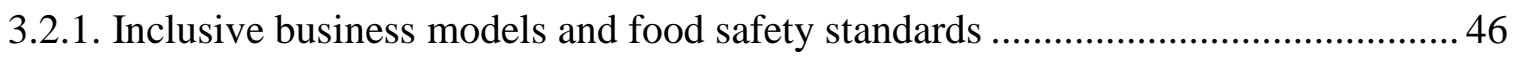

3.2.2. Certification groups in the GlobalGAP Option 2 project...................................... 47

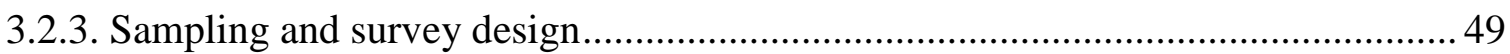

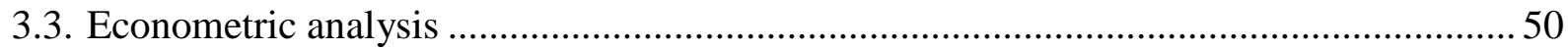

3.3.1. Impact of GlobalGAP certification on producer prices ........................................ 52

3.3.2. Impact of GlobalGAP on net household income .................................................. 55

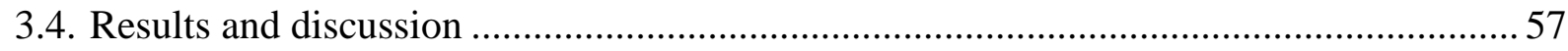

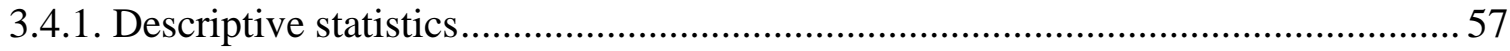

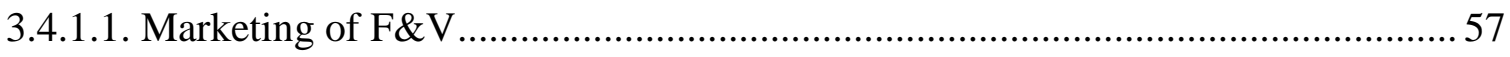

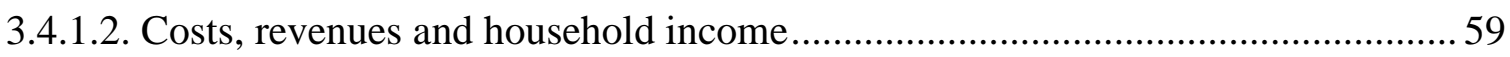

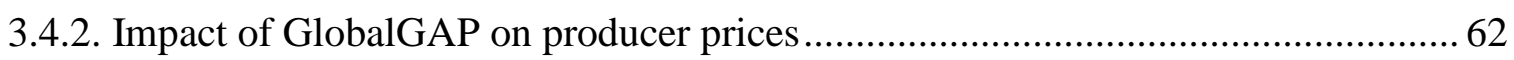

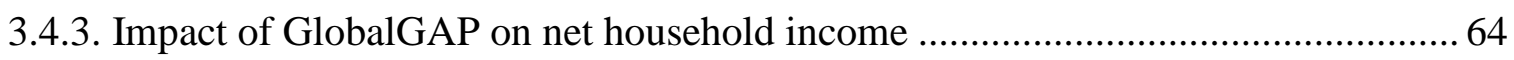

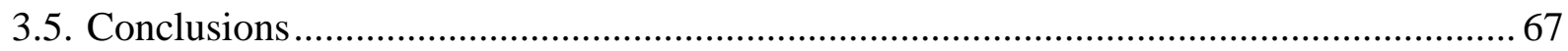

4. Is GlobalGAP certification of small-scale farmers sustainable? Evidence from

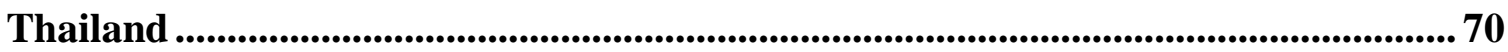

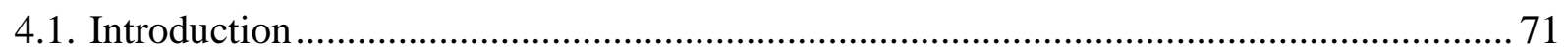

4.2. The GlobalGAP standard, small-scale farmers and donor support................................ 73

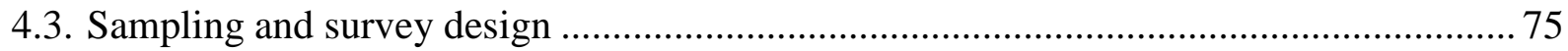

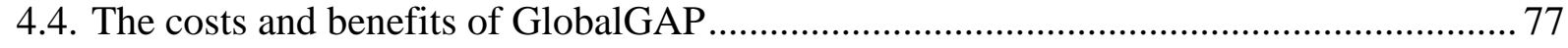

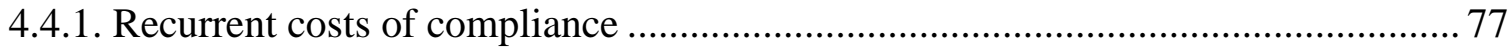




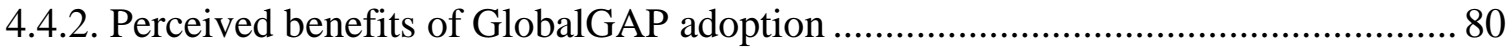

4.4.3. The impact of GlobalGAP certification on household income ............................... 82

4.4.3.1. Econometric approach to analyze income effects ........................................... 83

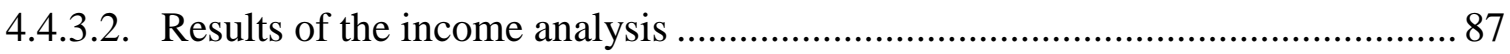

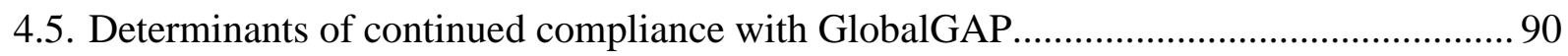

4.5.1. Econometric approach to analyze GlobalGAP adoption and continued

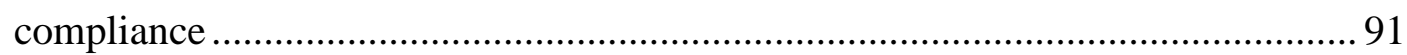

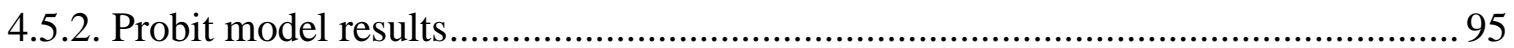

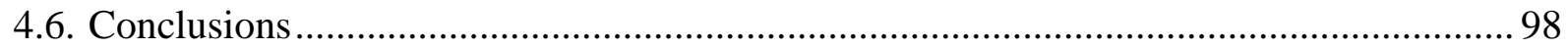

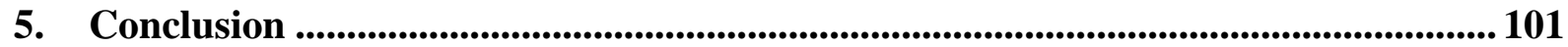

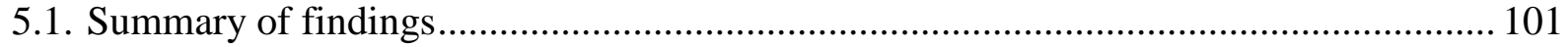

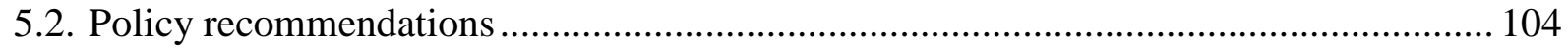

5.3. Limitations of the study and suggestions for further research ...................................... 106

Bibliography ....................................................................................................................... 108

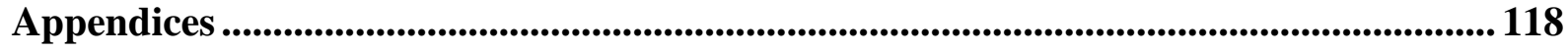

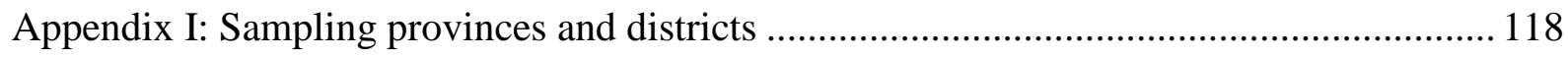

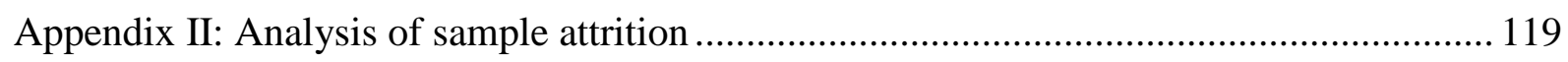

Appendix III: Impact of GlobalGAP certification - full models ...................................... 123

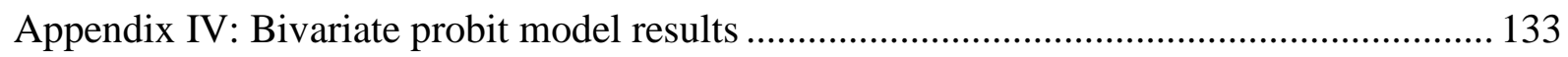

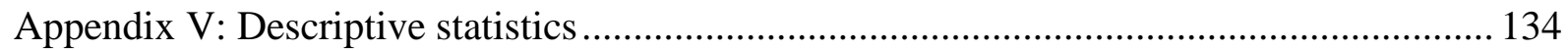

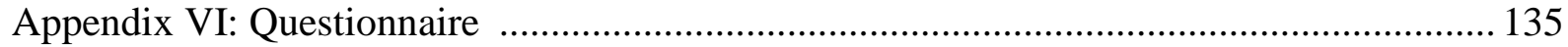




\section{List of tables}

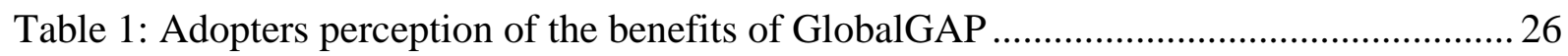

Table 2: Farmers' reasons for failed GlobalGAP implementation ......................................... 26

Table 3: Distribution of non-recurrent costs of compliance with GlobalGAP_

Case study of an exporter-managed asparagus farmer group in Thailand 28

Table 4: Annual recurrent costs of compliance with GlobalGAP- Case study of an exportermanaged asparagus farmer group in Thailand ...................................................... 29

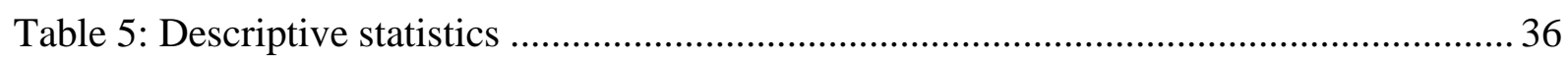

Table 6: Bivariate probit model estimates- Development program participation and

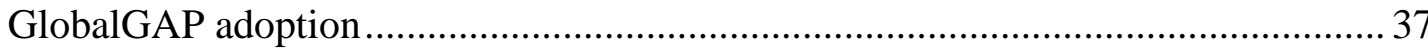

Table 7: Probit model estimates- The determinants of GlobalGAP adoption ......................... 38

Table 8: Differences in marketing of $\mathrm{F} \& \mathrm{~V}$ : prices, quantities, marketing channels and contracts .59

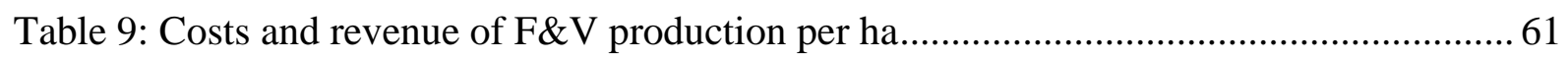

Table 10: Annual net household income in US Dollars by activity ....................................... 62

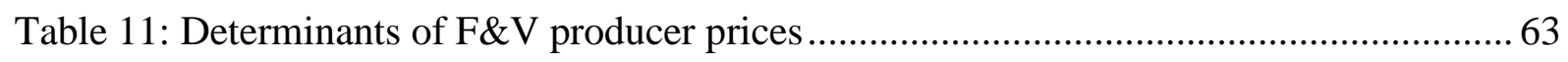

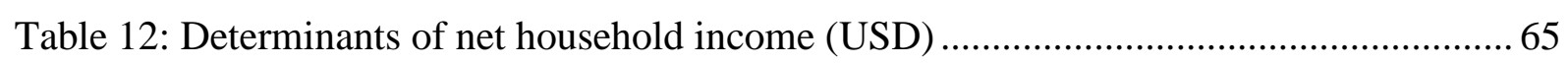

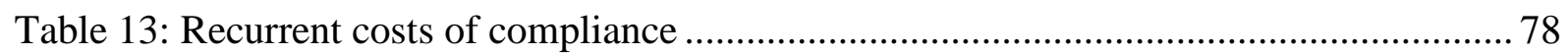

Table 14: Certified area and net F\&V income by quartile (in 2010) ..................................... 79

Table 15: Farmers' perceived benefits of GlobalGAP compliance ......................................... 81

Table 16: Descriptive statistics - Net household income (in USD) ........................................ 83

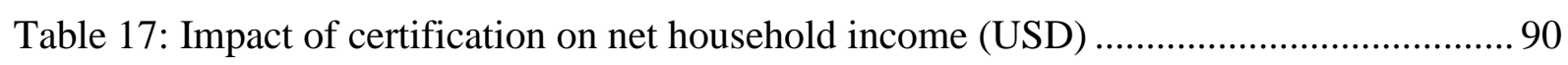

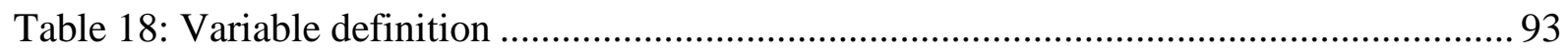

Table 19: Bivariate probit model estimating GlobalGAP adoption in 2010 and continued compliance in 2011 


\section{List of figures}

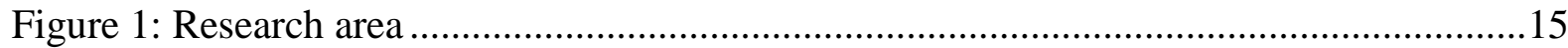

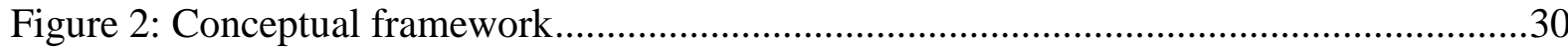

- Participation in the 'Food Safety in FFV' program and GlobalGAP adoption

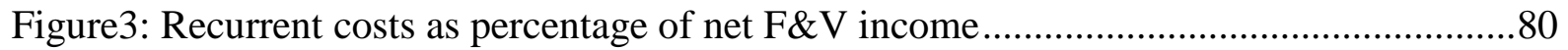




\section{List of abbreviations}

ASEAN

DfID

EU

E.g.

FAO

FFV

F\&V

GAP

GIZ

GTZ

$\mathrm{Ha}$

i.e.

$\mathrm{Kg}$

$\mathrm{n} / \mathrm{a}$

Std. error

THB

U.S.

USAID

USD
Association of Southeast Asian Nations

Department for International Development

European Union

For example

Food and Agriculture Organization of the United Nations

Fresh fruit and vegetables

Fruit and vegetables

Good agricultural practices

Deutsche Gesellschaft für Internationale Zusammenarbeit

Deutsche Gesellschaft für Technische Zusammenarbeit

Hectare

id est

Kilogram

Not applicable

Standard error

Thai Baht

United States of America

United States Agency for International Development

United States dollar 


\section{General introduction}

\subsection{The role of high-value agriculture in rural poverty alleviation}

The growth of the agricultural sector is crucial to achieve a sustainable economic growth and poverty reduction in developing countries. More than two thirds of the poor in developing countries live in rural areas and most of them rely on agriculture as the main income source (World Bank, 2007). The growth of the small-scale farm sector has an especially high potential to contribute to poverty reduction. Small-scale agriculture continues to dominate the farm structure in most developing countries, and of the 2.5 billion people involved in agriculture in developing countries, 1.5 billion are estimated to live in smallholder households (World Bank, 2007). One of the key instruments to reduce rural poverty is to enhance the participation of small-scale farmers in the growing domestic and global markets for highvalue agricultural products, such as meat, dairy products, fruits, vegetables (World Bank, 2007, Gulati et al., 2006, Weinberger and Lumpkin, 2007).

In the last three decades, a transformation of the agricultural sector in developing countries has taken place. The relative importance of staple crops and traditional export commodities (coffee, cacao, tea, sugar spices, and nuts) in agricultural trade and production has declined and a shift towards high-value products can be observed (Reardon and Timmer, 2007, World Bank, 2007, Humphrey and Memedovic, 2006). In developing countries, rapid economic growth, urbanization and globalization have induced changes in consumer diets away from staple foods towards an increased consumption of high-value products (World Bank, 2007, Gulati et al., 2006, Pingali, 2006). As a result, the domestic market for high-value products is one of the fastest growing agricultural markets in many developing countries, expanding by 67\% a year (World Bank, 2007). At the same time, the demand for specialty products and for a year-round supply of highly perishable fruit and vegetables has increased in industrialized countries, creating new exporting opportunities for many developing countries (World Bank, 2007). By 2004, exports of high-value products already accounted for $43 \%$ of total agrofood exports from developing countries (World Bank, 2007). In comparison, traditional tropical products only accounted for 19\% of food exports from developing countries in 2001 (Humphrey and Memedovic, 2006).

The horticultural sector, as one of the fastest growing sectors in the high-value segment, is discussed to contribute to poverty alleviation. Compared to the production of staple crops, fruit and vegetables cultivation is labor intensive, generates higher levels of employment and 
higher net incomes per hectare (Weinberger and Lumpkin, 2007, McCulloch and Ota, 2002). Moreover, due to the labor intensity fruit and vegetable cultivation is regarded to be especially suitable for small-scale family farms with a high ratio of available labor to arable land (Key and Runsten, 1999, Weinberger and Lumpkin, 2007). Global production of fruit and vegetables has more than doubled in the past thirty years, and an overwhelming share of the growth took place in developing countries (FAO, 2010). China experienced a nine-fold increase of its production between 1980 and 2010 and today is the largest producer of F\&V worldwide, followed by India. The growth of the horticultural production in Asia (without China), Africa and Latin America was also high with the first two growing on average 4.7\% per year and the latter 3.4\% per year (FAO, 2010). Moreover, developing countries increased their exports of fruit and vegetables ${ }^{1}$ more rapidly than developed economies. Between 2001 and 2011, developing countries' F\&V export value grew from 19.6 billion USD to 83.7 billion USD (International Trade Centre, 2012). Furthermore, the share of horticultural products in total agricultural exports has been rising and is expected to continue to rise faster than other agricultural commodities (Weinberger and Lumpkin, 2007, Humphrey and Memedovic, 2006).

However, in recent years, meeting the market requirements in high-value markets has become more challenging (Gulati et al., 2006). In particular, high-value export and domestic supply chains in developing countries are increasingly governed by a plethora of public and private food safety and quality standards (Henson and Reardon, 2005, Balsevich et al., 2003). Developed countries' public standards have long been criticized to act as non-tariff barriers to trade for exports from developing countries (Henson and Loader, 2001, Henson and Caswell, 1999, Otsuki et al., 2001). Private standards, however, often exceed the requirements of public standards and, although voluntary, become mandatory to access high-value markets worldwide (Dolan and Humphrey, 2000, Berdegue et al., 2005, Farina and Reardon, 2000, Jaffee et al., 2005). There is growing concern among the development community that smallscale farmers will lose access to high-value markets because of their inability to meet stringent private standards (Graffham et al., 2007b, Humphrey and Memedovic, 2006, Jaffee et al., 2011). First, adopting private standards usually entails high compliance and certification costs that disadvantage smallholders. Second, small-scale farmers often lack the technical ability to adapt their farming practices to the requirements of standards (Narrod et al., 2009, Jaffee et al., 2011). Yet, others argue that the challenge can also be turned into an

\footnotetext{
${ }^{1}$ Harmonized System 07 and 08.
} 
opportunity. Standards are discussed to encourage new forms of cooperation between producers and agribusinesses, to lead to the upgrading of supply chains and to facilitate access to new remunerative markets (Jaffee, 2003). Seen from this viewpoint, the adoption of standards can lead to higher and more stable incomes and thereby to a reduction of poverty and vulnerability among small-scale farmers. Given the potential opportunities and challenges of private food safety and quality standards, the aim of this study is to contribute to the understanding of the implications of standards for small-scale farmers, and to identify mechanisms that enable small-scale farmers to adopt standards and to benefit from standards in the long run. We do so by focusing on the GlobalGAP standard in the Thai horticultural sector. GlobalGAP is the most widely known standard for good agricultural practices and a requirement of major retailers worldwide.

\subsection{Public and private food safety and quality standards}

\subsubsection{Understanding the rise of private food safety standards}

In order to understand the implications of standards for small-scale farmers in developing countries, it is important to examine the causes of changes in public regulatory requirements and the connected rise of private food safety and quality standards.

In industrialized countries consumers are increasingly concerned over food safety and there is a rising awareness of the social and environmental impacts of food production. Over the last decades, a series of food safety scandals and disease outbreaks in a number of countries (for example, salmonella and E. coli outbreaks, bovine spongiform encephalopathy, dioxin in animal feed) has shaken consumer confidence in the prevailing food safety regulatory system (Jaffee et al., 2005, Henson and Reardon, 2005). Moreover, consumers' desire for credence quality attributes of food products that are unobservable at the point of purchase is increasing. In particular, there is a broadening concern over contaminants in food (e.g., microbial pathogens, heavy metals and pesticide residues), and over how products were grown and processed (e.g., animal welfare concerns, organic production, social and environmental concerns) (Henson and Reardon, 2005, Jaffee et al., 2011).

In response to these developments, governments, especially in the European Union, have tightened existing mandatory food safety standards, and a number of new standards have been developed for previously unknown or unregulated food safety hazards (Henson and Reardon, 
2005). At the same time, it became more difficult to demonstrate compliance with food safety standards as a result of a shift from product to process standards (Humphrey and Memedovic, 2006). While product standards define the characteristics of a product and are largely enforced through testing at borders, process standards are agreed criteria of how products are made and require the implementation and control of new procedures and management systems (FAO, 2003, Humphrey and Memedovic, 2006). Food safety today is seen as a product of the whole value chain, from primary production to the consumer, implying that risks have to be managed at all points of the value chain (Humphrey and Memedovic, 2006).

In parallel with these developments, the private sector introduced private standards for food safety and quality to meet consumers' concerns over food safety, to differentiate products based on quality attributes, to mitigate commercial risks and to ensure compliance with public regulations (Henson and Reardon, 2005, Reardon et al., 2009). These standards are mostly employed by lead firms in the food chain, such as major retailers, processors and food service firms, who have the market power to impose compliance with standards onto their producers (Humphrey and Memedovic, 2006). Initially, firms developed their own private standards (e.g., Tesco Nature’s Choice ${ }^{2}$, Carrefour Quality Lines ${ }^{3}$ ), but in recent years collective private standards that are developed by groups of firms or business associations have become even more important (Humphrey and Memedovic, 2006). For companies operating globally such standards reduce transaction costs and coordination costs by placing the responsibility that food is safe onto their suppliers (Humphrey, 2008).

Private standards, although voluntary, are becoming increasingly mandatory to supply highvalue markets worldwide, which also has consequences for producers in developing countries (Jaffee et al., 2011). In some cases, globally operating chains apply private standards from developed markets for suppliers in developing countries. One example is the GlobalGAP standard, a collective private standard for good agricultural practices, which was introduced by European retailers in 1997 with the aim to harmonize retailers' existing standards. Today GlobalGAP is a de-facto mandatory requirement for producers of fresh products to access the European market (Henson and Reardon, 2005). The importance of private standards, however, is not only rising in developing countries’ export supply chains, but also in domestic market supply chains that are increasingly dominated by globally operating supermarket

\footnotetext{
${ }^{2}$ Tesco Nature's Choice is an integrated farm management scheme unique to Tesco. The standard was created in 1992 to ensure that "fruit, vegetables and salad are grown to high safety, quality and environmental standards" (Tesco, 2005).

${ }^{3}$ In 1992, Carrefour initiated certification schemes for a range of different products, the Carrefour Quality Lines (CQL). The standards address a broad range of issues, such as food safety, environmental and animal welfare concerns (Corsin, Funge-Smith, \& Clausen, 2007).
} 
chains, such as Carrefour, Wal-Mart and Tesco (Reardon and Timmer, 2007). Starting in the 1990s, supermarkets have expanded rapidly in many developing countries as a result of rising incomes, urbanization and a higher participation of women in the workforce, coupled with foreign direct investment by mainly European, U.S. and Japanese supermarket chains (Pingali, 2006, Reardon et al., 2003). The extent of supermarket penetration in developing countries varies and is highest in Latin America and Asia. By 2000 the share of supermarkets in Latin America had already reached 50-60\% (Reardon et al., 2003). In East and Southeast Asian countries the share of supermarkets reached 30-50\% by mid 2000 (Reardon et al., 2012). According to Reardon et al. (2010), five main reasons can be identified for the increasing use of private standards by supermarkets in developing countries. First, they are implemented to substitute for inadequate or missing public standards. Second, urban consumers in developing countries are increasingly concerned over food safety as a result of recent food scandals and produce scares. Third, globally or regionally operating chains apply standards to produce sold via their regional or global procurement networks. These can be chain specific standards, such as Carrefour Quality Line or Tesco Nature's Choice, or collective standards (e.g., GlobalGAP). Fourth, in local markets standards help to coordinate supply chains and to reduce wastage. Fifth, they can be a tool to differentiate products from those sold by traditional retailers (Reardon et al., 2010). Given these developments, it is expected that private standards will increasingly govern not only export supply chains in developing countries, but also domestic supply chains.

\subsubsection{The case of the GlobalGAP standard}

The GlobalGAP ${ }^{4}$ standard, which we focus on in this study, is the most widely implemented farm assurance program today. GlobalGAP is a pre-farm gate standard that covers the process from farm inputs and all activities on the farm until the product leaves the farm (FoodPLUS, 2012c). The main focus of the standard is on food safety, but it also covers aspects of environmental protection, workers' health, safety and welfare and traceability (FoodPLUS, 2012c). The standard is based on third party certification, and farmers are audited from certification bodies accredited by FoodPLUS GmbH, the GlobalGAP secretariat

\footnotetext{
${ }^{4}$ GlobalGAP is jointly governed by retailers and producers. In 2012, 49 retailers and food services were members of GlobalGAP and 197 producers and suppliers. Of the latter, 32 came from developing countries (FoodPLUS, 2012c).
} 
(Humphrey, 2008). Initially, GlobalGAP was developed by European retailers ${ }^{5}$ to ensure that the produce they sell complies with public food safety regulations in the EU, and in response to pressures by consumers and NGOs to address the environmental and social impacts of food production (Humphrey, 2008). While still being mainly a requirement of major supermarkets in the EU, the standard has gained global relevance ${ }^{6}$ in recent years with retailers and food service firms from the U.S., Japan, and South Africa becoming members of GlobalGAP and imposing compliance with the standard onto their suppliers ${ }^{7}$ (FoodPLUS, 2012c, Humphrey, 2008). The number of GlobalGAP certified producers grew from 18,000 in 2004 to 112,600 in 2011 and today certified farmers can be found in 113 different countries. Europe continues to account for the majority of certificates (74\% in 2011), but the share of certificates is growing in Asia and Latin America (FoodPLUS, 2011a).

GlobalGAP offers two certification options ${ }^{8}$ : individual certification (Option 1) and group certification (Option 2). Compared to individual certification, group certification can make compliance with GlobalGAP feasible for small-scale farmers by reducing the costs of compliance for the individual producers and by making it easier for external service providers to provide farmers with advice and trainings (Will, 2010). Two main group types exist under GlobalGAP Option 2. The first is a farmers' association or cooperative where the group is managed by farmers, and the second is an outgrower scheme of a company, where the company organizes smallholders and manages the group (GTZ, 2010). In 2011, 70\% of the GlobalGAP certified producers worldwide were certified in a group (FoodPLUS, 2011a).

\subsubsection{Implications of standards for small-scale farmers in developing countries}

There is considerable evidence that adopting private food safety and quality standards is especially challenging for small-scale farmers (Roy and Thorat, 2008, Ashraf et al., 2009, Graffham et al., 2007b). Compliance with standards entails high up-front investments into

\footnotetext{
${ }^{5}$ GlobalGAP was named EUREPGAP until 2007. The name was changed to reflect the increasing global aspirations of the standard (FoodPLUS, 2012c).

${ }^{6}$ Moreover, GlobalGAP aims to globalize its standards by benchmarking them against other standards. For developing countries, the policy of GlobalGAP to promote the development and benchmarking of national standards is especially important. This allows for the development of standards which are adapted to national circumstances, while at the same time being recognized as equivalent to GlobalGAP (Humphrey, 2008). Among standards benchmarked against GlobalGAP are ChileGAP, KenyaGAP, ThaiGAP, ChinaGAP and MéxicoG.A.P. (FoodPLUS, 2012c).

${ }^{7}$ As of December 2012, 49 retailers and food service firms are members of GlobalGAP. Thereof, 41 are European, one is Japanese, two are South African, and five are from the United States (FoodPLUS, 2010c). ${ }^{8}$ In addition, Options 3 and 4 refer to individual and group certification under benchmarked schemes (Will, 2010).
} 
farm facilities and equipment, which smallholder are often not able to incur, especially if they lack access to credit (Jaffee et al., 2005). In addition, the costs of compliance with standards are to a large extent fixed costs which disadvantage small-scale producers (Jaffee et al., 2005, Chemnitz, 2007). Besides, the technical and information requirements of standards are high. Farmers have to adopt more sophisticated farming practices and they require producers to be informed about changing requirements of standards. However, acquiring information is also subject to economies of scale (Roy and Thorat, 2008, Narrod et al., 2009). Poor education levels and a lack of access to extension services and training programs further hinder the implementation of food safety and quality standards by small-scale farmers (Markelova et al., 2009).

Moreover, the adoption of standards is constrained by the prevalence of unsafe farming practices in developing countries. In particular, microbial contamination of fruit and vegetables is a severe problem as a result of poor hygiene practices, the use of untreated manure and polluted irrigation water (Shepard, 2006). Furthermore, pesticide overuse is common among small-scale farmers because pesticides provide an effective way to manage risks. Pesticides are frequently applied as a preventive measure, following a monthly or weekly spraying calendar, and the doses applied are often higher than recommended on the label (Shepard, 2006, Plianbangchang et al., 2009, Okello and Swinton, 2007). This practice is encouraged by the fact that in traditional supply chains the physical appearance is still the major factor for the determination of the market price (Shepard, 2006).

In response to the increasing demand for food safety and quality, changes in the structure of high-value export and domestic supply chains are taking place. In particular, there is a shift from open-market sourcing to integrated and coordinated procurement, which allows for a better monitoring of the production process on the farm (Jaffee et al., 2005, Gulati et al., 2006, Sriboonchitta and Wiboonpoongse, 2008, Pingali, 2006). However, the transaction costs of contracting and of monitoring food safety are higher for smaller than for larger farms. As a result, exporters and supermarkets increase sourcing from large-scale growers, where food safety is well controlled, and increase the production on company-owned farms (Buurma and Saranak, 2006, Gulati et al., 2006, Reardon et al., 2012, Dolan and Humphrey, 2000). Nevertheless, in countries where the farming system is dominated by small-scale farmers and land is scarce, it is imperative to find innovative approaches to enable small-scale farmers to participate in high-value markets and to adopt food safety and quality standards (Gulati et al., 2006, Jaffee et al., 2005, Dolan and Humphrey, 2000, Henson and Reardon, 2005). 
Furthermore, small-scale farmers have a comparative advantage in the production of laborintensive crops, such as fruit and vegetables, which can outweigh the higher transaction costs associated with contracting small-scale farmers (Key and Runsten, 1999, Dolan and Humphrey, 2000). Therefore, new forms of institutional arrangements are emerging which successfully integrate small-scale farmers into high-value chains. First, some companies use resource-providing contracts to enable small-scale farmers to fulfill the quality requirements in high-value supply chains and to adopt food safety and quality standards (Henson and Reardon, 2005, Buurma and Saranak, 2006, Manarungsan et al., 2005). Second, there are examples where collective action has enabled small-scale farmers to participate in high-value markets. By forming producer associations farmers can generate economies of scale, obtain information more easily and finance the investments associated with adopting standards (Roy and Thorat, 2008, Markelova et al., 2009, Narrod et al., 2009, Manarungsan et al., 2005).

In the light of the above mentioned challenges, several donors, governments and NGOs have initiated development programs to facilitate the adoption of private standards by small-scale farmers. Most initiatives focused on the GlobalGAP standard which became increasingly mandatory to supply the European market in the mid 2000s and therewith threatened to exclude small-scale farmers from high-value markets (Humphrey, 2008, Will, 2010). These programs supported the creation of farmer groups and offered financial assistance, training and information to the groups to achieve certification (Humphrey, 2008). Moreover, publicprivate partnerships were formed between donors and exporters to enable small-scale farmers to adopt the standard as part of exporter outgrower schemes (Narrod et al., 2009, Humphrey, 2008). Furthermore, several initiatives supported the development of national benchmarked standards, such as KenyaGAP and ThaiGAP, with the aim to adapt the GlobalGAP standard to national circumstances, and to make compliance easier for small-scale farmers. In addition, the development of local certification bodies such as AfriCert was supported to reduce certification costs, and the private sector was strengthened to provide support services needed to adopt private standards (Humphrey, 2008).

\subsubsection{The role of standards in the Thai fruit and vegetable sector}

This study focuses on the implication of food safety and quality standards for small-scale farmers in the Thai fruit and vegetable sector. Thailand is one of the largest producers and exporters of horticultural products in the world, and therewith among the developing 
countries most affected by increasing standards (Jaffee et al., 2005, Manarungsan et al., 2005). Moreover, super- and hypermarkets in Thailand ${ }^{9}$ capture an increasing share of fresh produce sales, which contributes to a growing relevance of standards in the F\&V domestic supply chains (Pingali, 2006, Reardon et al., 2012, Wiboonpongse and Sriboonchitta, 2004, Buurma and Saranak, 2006). In 2002, it was estimated that super- and hypermarkets already accounted for $40 \%$ of fruit sales and $30 \%$ of vegetables sales in the Bangkok area, while the share was still lower but increasing in other areas (Shepherd, 2005).

The case of Thailand is also relevant from a development perspective. Thailand, similar to many other emerging economies in Asia, experienced rapid economic growth in the last decades, which has led to falling poverty rates since the 1980s. However, economic growth was unequal. Although poverty rates have fallen to $8 \%$ by 2009, poverty remains widespread in rural areas. Of the 5.4 million poor in Thailand, 88\% live in rural areas (World Bank, 2012). Thus, the agricultural sector, as the biggest employment ${ }^{10}$ and income generator for the rural population, plays a critical role to alleviate poverty (Wipplinger et al., 2006, Asian Development Bank, 2012). Diversification into horticultural production offers the opportunity for Thailand's large population of smallholders to increase their incomes (Chainuvati and Athipanan, 2001). The average farm size in Thailand is 3.6 ha and more than a quarter of the approximately 5.7 million farms in Thailand are smaller or equal to 1.6 ha (Pongsrihadulchai, 2009).

Thailand was the $17^{\text {th }}$ largest producer of fruits and the $27^{\text {th }}$ largest producers of vegetables in 2010 (FAO, 2010). Moreover, the country is a significant player in fruit and vegetable exports. In 2011, the country's F\&V exports amounted to 2.3 billion USD, making Thailand the $10^{\text {th }}$ biggest exporter of vegetables (HS 07) and $22^{\text {nd }}$ biggest exporter of fruits (HS 08) (International Trade Centre, 2012). Exports mainly go to Asian markets and in 2011, 46\% of fruit exports (HS 08) in value terms went to China, 19\% to countries in the Association of Southeast Asian Nations (ASEAN) and 16\% to Hong Kong. Only 4\% are exported to the U.S. and 3\% to Europe (International Trade Centre, 2012). For vegetables (HS 0701-0713) ${ }^{11}$, the European and North American markets are of relatively more importance, with a $14 \%$ and $9 \%$

\footnotetext{
${ }^{9}$ In Thailand, super- and hypermarket expansion started in the mid 1990s and in the early 2000, the share of supermarket sales of processed and packages food was already estimated to be at 33\% (Reardon et al., 2003). Since then, food retailers continued to grow at 16\% annually between 2001 and 2009 (Reardon et al., 2012).

${ }^{10}$ In 2010, the agricultural sector provided 39\% of the employment although it only accounted for $11 \%$ of the Gross Domestic Product (Asian Development Bank, 2012).

${ }^{11}$ HS 0714 (Manioc, arrowroot salem etc.) is excluded from the analysis because almost the total production of cassava in Thailand is processed into dry chips and pellets and then exported as animal feed (Ratanawaraha et al., 2012).
} 
market share in 2011 respectively. Nevertheless, the biggest proportion of vegetables exported went to regional markets; 37\% were exported to Japan and 19\% to ASEAN (International Trade Centre, 2012). Moreover, Thailand's vegetable exports to Europe have fallen steadily from 62.1 Million USD in 2007 to 42.3 Million USD in 2011 (International Trade Centre, 2012), which can partly be attributed to difficulties in meeting the increasingly strict standards in the European Union (EU). Only recently, the Thai government voluntarily imposed a temporary ban on exports of sixteen kinds of vegetables to the EU due to quarantine issues in order to avoid a formal ban by the EU (Ussavasodhi, 2011).

The Thai public and private sectors have responded actively to the increasingly stringent standards in the EU, North America and Japan in order to prevent the loss of market access (Jaffee et al., 2005, Manarungsan et al., 2005, Sardsud, 2007). In 2004, the Thai government passed the 'Road Map of Food Safety' with the aim to implement effective food safety controls at all levels of the value chain (Sardsud, 2007, Ministry of Public Health, 2004). As part of the initiative and to improve the level of food safety at farm level, a national voluntary standard for good agricultural practices, the Q-GAP standard, was established in 2004. The standard is a requirement of several domestic retailers, and plays an important role in the export sector (Wannamolee, 2008, Sardsud, 2007). The private sector, however, assesses the Q-GAP standard as insufficient ${ }^{12}$ and in response initiated the development of ThaiGAP ${ }^{13}$, a private voluntary standard that was recognized as equivalent to GlobalGAP in 2010. The standard is adapted to the circumstances of Thailand and thus expected to be easier and less costly to comply with than GlobalGAP (Keeratipipatpong, 2010). Furthermore, there are initiatives ${ }^{14}$ under way by leading supermarket chains in Thailand to develop "intermediate” private standards that ensure a higher level of food safety than the Q-GAP standard, but are less challenging to comply with than the GlobalGAP/ThaiGAP standard (Wattanavaekin, 2011).

\footnotetext{
12 The standard is criticized for lacking credibility because both certification and accreditation are in the hands of the government and the agencies responsible for certifying farmers lack adequate financing (Sardsud, 2007).

${ }^{13}$ The ThaiGAP standard is an outcome of a public-private partnership between the Thai Chamber of Commerce, Kasetsart University, the National Food Institute, the National Metrology Institute of Germany, and the German Technical Co-operation (Keeratipipatpong, 2010).

${ }^{14}$ One example is the ThaiGAP standard level 2 for the domestic market that was pilot tested with suppliers of the following retailers: Tesco, Tops, Makro, and Big C (Wattanavaekin, 2011).
} 


\subsection{Problem statement}

The increasing relevance of private standards in high-value supply chains offers new challenges as well as new opportunities for small-scale farmers in developing countries. In the focus of the current debate on the implications of standards for smallholders stands the GlobalGAP standard. A growing body of literature deals with the determinants of GlobalGAP adoption, the associated costs of compliance and with the financial, environmental and social benefits of compliance (Ouma, 2010, Asfaw et al., 2010, Asfaw et al., 2009a, Asfaw et al., 2009b, Kariuki et al., 2012, Chemnitz, 2007, Graffham et al., 2007b, Mausch et al., 2009).

Existing studies find that small-scale farmers are disadvantaged in the compliance process with GlobalGAP, and that adoption is further influenced by the educational attainment of households, household wealth, group membership, vertical integration and by access to extension services and credits (Asfaw et al., 2009b, Okello, 2005, Kleinwechter and Grethe, 2006, Chemnitz, 2007). However, these studies neglect the role of support by donors, publicprivate partnerships and exporters in the compliance process. GlobalGAP adoption by smallscale farmers has in many cases been facilitated through financial, managerial and technical support by donors and exporters (Humphrey, 2008, Will, 2010, Jaffee et al., 2011, Graffham et al., 2007b), leading to our hypothesis that support is critical to enable small-scale farmers to adopt the standard.

Moreover, concerning the financial benefits of GlobalGAP certification, previous studies have so far been inconclusive and many open questions remain. While some argue that GlobalGAP is a quasi-mandatory minimum standard and does not lead to price premiums and higher incomes (Ouma, 2010, Graffham et al., 2007b, Subervie and Vagneron, 2012), others identify positive effects on producer prices, farm level productivity and net income from export vegetable production (Asfaw et al., 2009a, Asfaw et al., 2009b, Kariuki et al., 2012). These studies provide important indications through which channels GlobalGAP certification may impact farmers' net household income. Yet, to our knowledge there are no existing studies which specifically analyze the impact of GlobalGAP certification on net household income. Solely focusing on income from export crop production may lead to biased results because farmers who adopt GlobalGAP may allocate resources away from other activities to increase their export crop production.

Furthermore, previous studies have investigated the average treatment effects of GlobalGAP adoption (Asfaw et al., 2010, Asfaw et al., 2009a, Kariuki et al., 2012, Subervie and 
Vagneron, 2012). This, however, may disregard important heterogeneous effects of certification. The majority of small-scale farmers in developing countries are certified in farmer groups and certification can be producer-driven or buyer-driven. We hypothesize that the impacts of GlobalGAP certification differ depending on whether farmers are certified in exporter-managed groups or producer-managed groups. Likewise, the costs of compliance associated with GlobalGAP certification are to a large extent fixed costs and therefore we expect certification to be more profitable for larger than for smaller farmers.

In addition, previous empirical studies on the impacts of GlobalGAP adoption relied on cross sectional data sets. We improve upon these approaches by using a panel data set of Thai fruit and vegetable farmers for our analyses, which we collected in 2010 and 2011. The availability of panel data allows us to control for non-random selection of farmers into GlobalGAP certification that is based on unobservable time-invariant characteristics.

Besides the challenge to overcome the barriers to standard adoption, there is increasing evidence that continued compliance with standards often represents a major challenge to small-scale farmers. After initial adoption, many small-scale farmers disadopt the standard in later years because they are unable to continuously meet the strict requirements and high costs associated with food safety standards. In particular, several studies report that donor facilitated GlobalGAP adoption was not sustainable and farmers abandoned the standard following the withdrawal of donors (Graffham et al., 2007a, Bignebat and Vagneron, 2011, Humphrey, 2008, Graffham et al., 2007b). Given that sustainable effects on poverty reduction can only be achieved if small-scale farmers are able to comply with standards in the long run, identifying the factors that influence continued compliance is critical.

\subsection{Objectives of the study}

This study aims to analyze the implications of the GlobalGAP standard for small-scale farmers by focusing on the Thai fruit and vegetable sector. In particular, we aim to contribute to the existing literature by identifying new institutional arrangements which enable smallscale farmers to adopt the GlobalGAP standard and to benefit from adoption in the long run. Given the research gaps in the literature identified above, the objectives of the study are as follows: 
- To identify the factors that influence GlobalGAP adoption, taking into account the support by donors, public-private partnerships and exporters

- $\quad$ To assess the average and subgroup-specific mean impacts of GlobalGAP certification on producer prices and on farmers' net household income

- To analyze the determinants of continued compliance with GlobalGAP following the withdrawal of donor support

\subsection{Data collection}

To address our research questions, we carried out a two-year panel data survey among Thai fruit and vegetable farmers. To date, the number of GlobalGAP certified producers in Thailand is relatively low and before the start of the first survey in 2009 only 923 producers were certified with the GlobalGAP standard (FoodPLUS, 2009b). Therefore, to have a sufficiently high number of GlobalGAP adopters in our sample, we stratified the relevant population of fruit and vegetable farmers according to participation in a development program ${ }^{15}$ which aimed to enable small-scale farmers to adopt the GlobalGAP standard. The program was carried out between 2008 and 2010, and within the first half of 2010, several of the participants successfully obtained a GlobalGAP certificate.

The first round of data collection was conducted between March and May 2010 and the second between March and May 2011. Both surveys cover a one-year interval from March to the end of February and thus the first survey corresponds to the period before GlobalGAP certification for adopters in our sample ${ }^{16}$ and the second to the time period following certification. Our survey area (see Figure 1) covers thirty districts ${ }^{17}$ in fourteen provinces ${ }^{18}$ of Northern, Southern, Central and Eastern Thailand. Of these, twenty districts are program regions and ten districts were selected as external control areas.

\footnotetext{
15 The development program was implemented by the Deutsche Gesellschaft für Internationale Zusammenarbeit (GIZ).

${ }^{16}$ None of the sampled non-participants was GlobalGAP certified or obtained a certificate during the period.

${ }^{17}$ See appendix I for a complete list of the districts.

${ }^{18}$ Interviews were carried out in the following provinces: Kanchanaburi, Ayuttayah, Nakhon Pathom, Ratchaburi, Samut Sakhorn, Saraburi (Central Thailand), Sa Kaew, Chachoengsao, Prachin Buri (Eastern Thailand), Chumporn (Southern Thailand), Phayao, Phichit, Chiang Mai (Northern Thailand).
} 
For the interviews, a structured questionnaire ${ }^{19}$ was used and information on a wide range of topics was collected including socio-economic and farm characteristics, agricultural production and input use, marketing, group membership, compliance with standards, access to information, trainings and extension services. The questionnaire was translated into Thai and pre-tested in the field to identify potential mistakes and to further improve the questionnaire. We recruited master students from a local agricultural university as enumerators who showed a good knowledge of horticultural production systems. Before the start of the data collection, the selected students received a one-week training in the classroom and in the field.

During the first survey in 2010, we interviewed 287 households. Thereof, 146 are program participants, 84 are non-participants within program regions and 57 are non-participants outside program regions. The following year, we were able to interview 218 of the 287 households a second time.

\footnotetext{
${ }^{19}$ An English version of the questionnaire can be found in the appendix. The questionnaire used in 2011 is slightly different to the one used in 2010 . We made small changes in the formatting and added a few additional questions.
} 


\section{Figure 1: Research area}

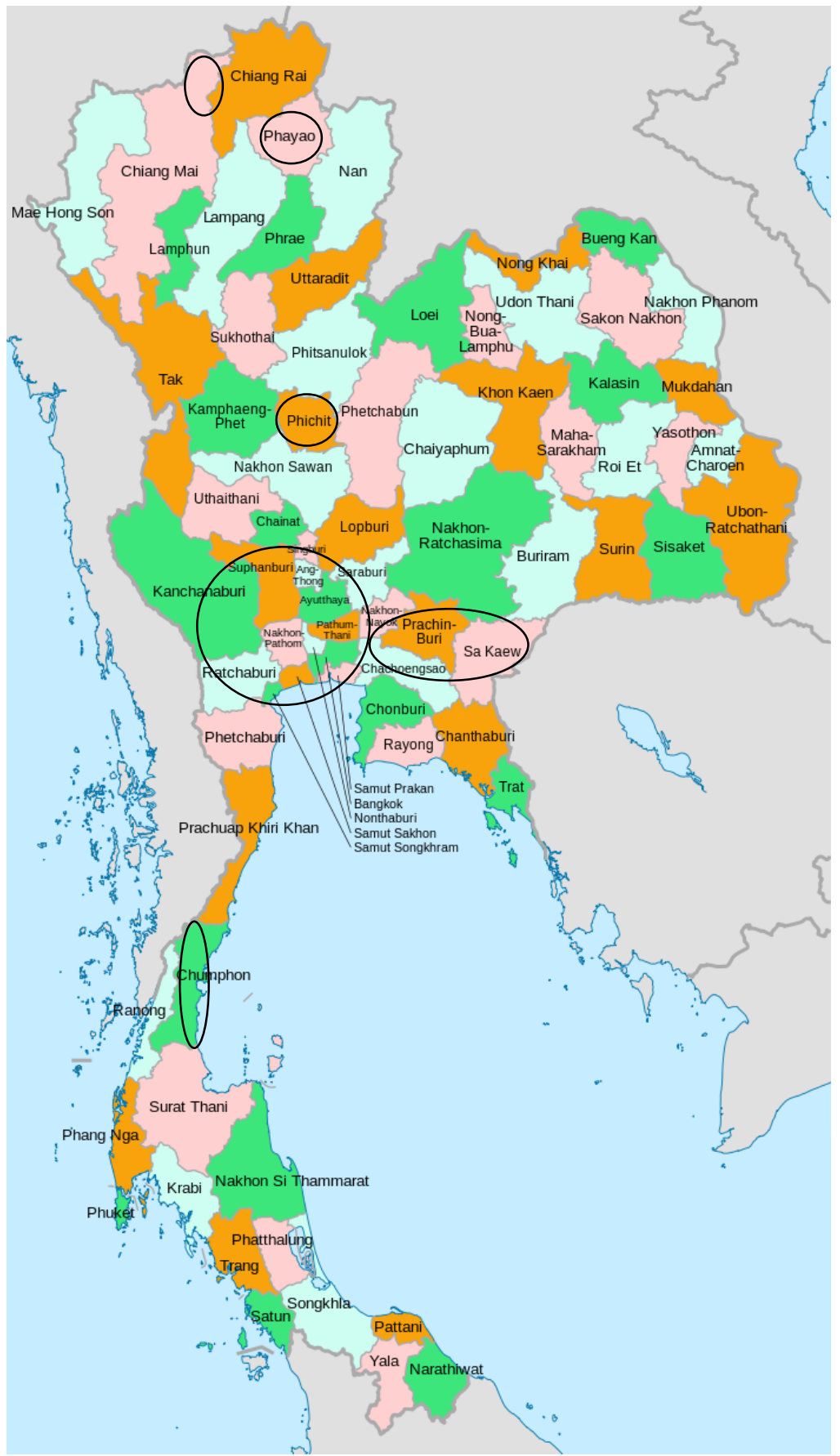

Source: Adapted from Wikipedia, 2012

\subsection{Outline of the study}

The study is organized as follows. Chapter 2 addresses the first objective of this study and analyzes the factors influencing GlobalGAP adoption, assuming that donor support is necessary to enable small-scale farmers to adopt the standard. In addition, the chapter 
provides background on GlobalGAP group certification and explores the costs and perceived benefits of complying with GlobalGAP for farmers and exporters.

Chapter 3 gives an overview on business models that can enable small-scale farmers to adopt the GlobalGAP standard and analyzes the impacts of GlobalGAP certification on producer prices and farmers' net household income. In addition to estimating the average effects of certification, the chapter explores mean treatment effects for subgroups of farmers certified in exporter-managed and producer-managed groups.

Chapter 4 focuses on the third objective of this study and analyzes the determinants of continued compliance with GlobalGAP. Since the decision to become re-certified is likely to depend on whether farmers are rewarded for compliance, the chapter also explores the costs and benefits of certification. In particular, the impact of certification on farmers' net household income is analyzed, taking into account the annually occurring recurrent costs of compliance.

Finally, Chapter 5 concludes with a summary of the results of the study and provides policy recommendations. Furthermore, the limitations of the study are discussed and suggestions for further research are made. 


\title{
2. New institutional arrangements and standard adoption: Evidence from small-scale fruit and vegetable farmers in Thailand ${ }^{20}$
}

\begin{abstract}
GlobalGAP is the most important private standard for producers in the Thai horticultural sector concerning access to high-value markets, especially to Europe. This chapter presents an analysis of GlobalGAP adoption by small-scale fruit and vegetable farmers in Thailand focusing on GlobalGAP group certification, the costs and perceived benefits of GlobalGAP adoption, and the factors influencing standard adoption. In our research area, GlobalGAP group certification has encouraged the formation of new institutional arrangements between farmers, exporters and donors. Farmers participating in a development program were organized in certification groups where the Quality Management System (QMS) was either run by the donor, by the exporter, or by farmers themselves. Results of our adoption model suggest that support by donors, exporters and public-private partnerships are vital to enable small-scale farmers to adopt the standard. Furthermore, farmers are more likely to adopt if they are better educated and more experienced, and if they have access to female family labor, improved farming technology, and information and extension services.
\end{abstract}

Keywords: Private standards; food safety; GlobalGAP adoption; new institutional arrangements; small-scale farmers

\footnotetext{
${ }^{20}$ This chapter was published as a journal article in Food Policy 37 (2012) 452-462. The co-author of this article is Meike Wollni. DOI: http://dx.doi.org/10.1016/j.foodpol.2012.04.005
} 


\subsection{Introduction}

Diversification into horticultural production is generally regarded to contribute to poverty alleviation. Horticultural crops are labor intensive and studies from South and Southeast Asia show that the per capita incomes of fruit and vegetable producers are often higher than those of cereal producers (Weinberger and Lumpkin, 2007). However, the opportunities the horticultural sector opens up for farmers in developing countries can be impeded by the proliferation of public and private food safety standards (Dolan and Humphrey, 2000). The fresh fruit and vegetables (FFVs) sector is an increasingly buyer-driven chain (Gereffi, 1994) in which large firms, especially supermarkets, determine the conditions such as scale, volume of procurement, consistency and compliance with standards (Jaffee and Masakure, 2005, Boselie and Kop, 2005, Henson and Reardon, 2005).

In Thailand, exporters, especially those with markets in the European Union (EU) and Japan, are shifting away from open-market sourcing to integrated and coordinated procurement in order to meet increasing food safety and traceability requirements (Jaffee et al., 2005, Sardsud, 2007). Meeting private standards, first and formemost the GlobalGAP standard, is one of the major challenges Thai fruit and vegetable producers and exporters face today to upgrade their production. GlobalGAP is a pre-farm gate ${ }^{21}$ standard for good agricultural practices that concerns aspects of food safety, environmental protection, workers' health, safety and welfare, and traceability (FoodPLUS and GTZ, 2008). It has been initiated in 1997 by a group of European retailers with the objective of harmonizing their own, often divergent standards and establishing one single standard applicable to all agricultural products worldwide. GlobalGAP offers two certification options, individual certification under Option 1 and group certification under Option $2 .^{22}$ The latter is especially important in a developing country context since it can make certification feasible for smallholders. In recent years, GlobalGAP has gained global relevance and the standard is especially important for exporters supplying the European market (Will, 2010, Henson et al., 2011). Against the background of a recent temporary ban on exports of 16 kinds of vegetables from Thailand to the EU, compliance with GlobalGAP becomes even more important in order to prevent the loss of market access to the EU (Ussavasodhi, 2011).

\footnotetext{
${ }^{21}$ A pre-farm gate standard means that the certificate "covers all on-farm processes from inputs through farming until the product leaves the farm" (Will, 2010).

${ }^{22}$ There are two additional certification options. Under Options 3 and 4, growers are certified as meeting an equivalent, national or local ('benchmarked') standard (Will, 2010).
} 
Complying with standards such as GlobalGAP can be associated with high implementation costs and there is an ongoing debate on whether or not the proliferation of food safety and quality standards is overall beneficial for exporters and producers in developing countries (Maertens and Swinnen, 2009, Reardon et al., 2009). On the one hand, standards are discussed to exclude certain types of producers from supply chains and thus worsen inequality (Dolan and Humphrey, 2000). On the other hand, standards might facilitate access to new markets, enhance product quality, add value and encourage new or enhanced forms of cooperation between producers and agribusinesses (Jaffee, 2003). Here, we primarily focus on identifying the circumstances under which smallholders are able to comply with standards.

The adoption of a standard such as GlobalGAP usually requires substantial investments in technological change and upgrading at the producer level. Resource-poor farmers might not be able to finance these investments, if they do not have access to credit or other sources of liquidity. Moreover, farmers in developing countries often lack access to information and extension services and have only insufficient human capital and organizational skills to comply with standards (Boselie and Kop, 2005, Narrod et al., 2009, Vorley and Fox, 2004). Previous empirical studies on the factors influencing GlobalGAP adoption have shown that farmers are less likely to adopt the standard if they possess smaller farms, are less integrated and less organized, have less physical, social and human capital and lack access to credits (Asfaw et al., 2009b, Chemnitz, 2007, Okello, 2005).

Up until now, to the best of our knowledge, no studies have explicitly addressed the role of donor assistance, public-private partnerships, and support by exporters in the compliance process with standards. This study extends the existing literature by analyzing the factors influencing GlobalGAP adoption conditional on donor support assuming that it is necessary for small-scale farmers in order to adopt the standard. Moreover, the costs and perceived benefits of GlobalGAP adoption for farmers and exporters will be discussed. Survey data of 231 households in the Thai horticultural sector is used of which 146 households have participated in a development program named 'Food Safety in Fresh Fruit and Vegetables' (Food Safety in FFV) which aimed to increase the access of Thai small-scale farmers to the GlobalGAP standard.

The chapter proceeds as follows. The next section describes the background to the study and the survey design. Then, the farmers' and exporters' perceived benefits of GlobalGAP adoption and the costs of compliance with the standard are presented. Afterwards, the empirical model for GlobalGAP adoption is specified and the results of the study are 
discussed. The last section concludes with a summary of the main results of the study presented in this chapter and derives policy implications.

\subsection{Background to the study and data}

\subsubsection{GlobalGAP group certification}

There are two main group types that can apply for group certification. The first type is a farmer group or cooperative that is managed by the growers themselves or by a donor. The second type is an outgrower scheme of a company, i.e., the company organizes and manages a group of smallholders for certification (GTZ, 2010).

GlobalGAP group certification has many advantages but also some disadvantages for smallholders. When farmers are linked together in a group, they can benefit from economies of scale by sharing necessary facilities for GlobalGAP adoption, such as a pesticide store and toilets and by centralizing some of the requirements (e.g. record keeping). In addition, a group structure reduces transaction costs of providing farmers with advice and trainings (Narrod et al., 2009, Will, 2010). Furthermore, the costs for the external audit are lower for each individual farmer because under Option 2, the certification body does not inspect all members of the group, but only the square root of the total number of group members. However, to guarantee that the sample of members represents the group as a whole, the groups have to run a Quality Management System (QMS). The QMS is a quality assurance system that specifies the rules of production for the group members and ensures that there is a mechanism in place that monitors and controls the compliance of group members with the GlobalGAP requirements. Depending on the type of group, the QMS is centrally managed either by the group members themselves, by a donor or by a buyer.

Setting-up and running the QMS is especially difficult for farmer-managed groups because their members are often time constrained and have low educational levels. For some of the QMS team positions, GlobalGAP sets high qualification requirements. A QMS team's Internal Inspector and Internal Auditor are required to have a post-high school degree in horticulture, to be trained in HACCP, food hygiene, GAP, and to have participated in a 2-day internal QMS auditor training course. Smallholder groups in developing countries often rely on external support to implement and run the QMS. In practice, farmers are only rarely members of the QMS team (GTZ, 2010, Ouma, 2007). 
In addition to the administrative challenges, the costs of implementing and running the QMS have to be considered, such as the costs for the QMS development, the monitoring of group members, internal audits and wages of QMS staff. Due to the high costs of the QMS, group certification is not economically viable for small groups with a low production volume. Also, for exporters a certain size threshold of their outgrower schemes is critical, given that the costs of monitoring and providing technical support are particularly high when individual farms are small and members dispersed (Ouma, 2007, GTZ, 2010, Battisti et al., 2009). Therefore, for very small groups, certification under Option 1 as a multi-site operation ${ }^{23}$ without QMS may be more feasible. Under this certification option, one organization or individual producer is the owner of several production locations or management units that do not act as separate legal entities (FoodPLUS, 2009a). Farmers can, e.g., rent out plots to a company and de facto act as farm managers for the company. While this certification option might be preferable for exporters under certain circumstances, since the costs for the QMS are saved, it also means that farmers have to abandon full control over their farms.

\subsubsection{New institutional arrangements and standards in the Thai FFV sector}

The rising importance of standards has led to considerable changes in the structure of the Thai FFV supply chain. The development of new institutional arrangements has been vital in order to deal with the challenge of complying with stringent food safety and quality standards. To ensure that their produce meets the required standards, exporters supplying high-value markets have pursued three strategies: to increase production on own farms, to source from large-scale farms where the production process is well controlled and to intensify contractual relations with smallholders, often through farmer groups. The third option is especially relevant in the Thai context due to the fact that land is scarce and large areas of suitable land are hard to find (Jaffee et al., 2005). Concerning GlobalGAP adoption, the usual strategy of exporters is to first gain a certificate for their company farms. When the demand for certified produce increases, exporters often organize their suppliers in farmer groups and offer them technical and financial support to achieve GlobalGAP compliance.

If the exporter runs the QMS for the group, the relationship between the company and the farmers becomes especially close. To ensure that all members comply with the standard, the

\footnotetext{
${ }^{23}$ Alternatively, farmers may choose to obtain individual certification under Option 1, but this is only feasible if individual farm sizes are relatively large.
} 
company’s QMS team usually exercises full control over the farmers' production process. Often, companies send own sprayer teams to the farms and manage record keeping for the farmers. For farmers, this can have positive and negative implications. On the one hand, farmers lose autonomy of their farms and they might be forced by contract to sell to the company who operates the QMS and owns the GlobalGAP certificate. On the other hand, they receive technical and financial assistance, and they might have a guaranteed market and even gain price premiums (GTZ, 2010).

However, not all exporters in Thailand have the same capacity to deal with the rising demand for standards. While larger exporters are likely to benefit from the new market developments and increase their market share, smaller exporters might lose access to high-value markets in the long run, if they are not able to comply with rising standards. It is important to note that the access of small-scale farmers to higher standards hinges on the compliance decision of exporters. If exporters are not able to comply with standards or do not assess compliance as being profitable, this also has negative implications for producers up the value chain (Henson et al., 2011).

In response to the challenges imposed by increasing standards, several food safety initiatives have been launched by the Thai public and private sectors and by donor agencies. One such example is the donor-led program 'Food Safety in FFV', ${ }^{24}$ which addresses the need for assistance by exporters and producers in adopting the GlobalGAP standard. Since the program's primary aim was to increase the access of smallholders to higher standards, it focused on group certification and followed three approaches. Firstly, it helped farmers to organize themselves and supported them in adopting the GlobalGAP standard. Farmers in these groups had to run the QMS on their own. Secondly, the donor linked farmers in a group and ran the QMS for the farmers. ${ }^{25}$ Thirdly, it formed public-private partnerships with six exporters who wished to obtain a GlobalGAP certificate, but needed assistance in doing so. The exporters supported the formation of certification groups, overtook the major share of the investment costs and also ran the QMS. All certification groups, farmers, and exporters received consultancy services and trainings on the GlobalGAP requirements to facilitate the implementation process. The intensity of donor support, however, differed between the group

\footnotetext{
${ }^{24}$ The program was funded by the German Federal Ministry for Economic Cooperation and Development (BMZ) and implemented by the German International Cooperation (GIZ).

${ }^{25}$ According to GlobalGAP rules, the holder of the certificate has to be a legal entity. In this case, the farmer group is the holder of the certificate, but the donor employed a team of farm advisors to run the QMS for the group.
} 
types. While the group with the donor-run QMS received the highest support, the exportermanaged groups received the least support from the donor.

\subsubsection{Data}

Data collection for the study took place between March and May 2010 in four of the six agroecological regions of Thailand. ${ }^{26}$ Our population consists of fruit and vegetable farmers located in the area where the 'Food Safety in FFV' program was implemented. In total, 231 producers were interviewed of which 146 farmers are participants in the 'Food Safety in FFV' initiative (97 GlobalGAP adopters and 49 non-adopters) and 85 are non-participants.

For the sampling, we divided the population into three strata: (1) program participants who adopted GlobalGAP ( $\mathrm{N}=118)$, (2) program participants who did not adopt GlobalGAP ( $\mathrm{N}=237)$, and (3) non-participants ( $\mathrm{N}=$ approx. 710). Farmers are classified as GlobalGAP adopters if they are certified with the standard or are in the adoption process and expect to achieve certification by 2011 or before. We also included farmers who were certified before the survey, but already decided to disadopt the standard, in the category of adopters. Sampling of program participants was based on a complete list of farmers provided by the 'Food Safety in FFV' program including complete names of the farmers, location and adoption status. To obtain a sufficiently large sample of adopters, we selected all GlobalGAP adopters for interviews. Of the 118 households listed, 97 were available for interviews. For the second strata, we selected 49 households randomly from the list of non-adopters.

For households not participating in the program, lists were not available. Non-participants were therefore selected through a random walk and chosen based on two criteria. First, they were required to live in the same village as the program participants and second, they had to produce the products ${ }^{27}$ that were considered for GlobalGAP certification by the participants in the respective village. The total number of eligible non-participant households was estimated previous to the survey through discussions with stakeholders of the 'Food Safety in FFV' program and through own observations during visits in the villages where the development

\footnotetext{
${ }^{26}$ Interviews were carried out in the following provinces: Kanchanaburi, Ayuttayah, Nakhon Pathom, Ratchaburi, Samut Sakhorn, Saraburi (Central Thailand), Sa Kaew, Chachoengsao, Prachin Buri (Eastern Thailand), Chumporn (Southern Thailand), Phayao, Phichit (Northern Thailand).

${ }^{27}$ The following products were considered for GlobalGAP certification: lychee, durian, mangosteen, papaya, dragon fruit, cantaloupe, mango, asparagus, green okra, spring onion, yard long bean, different kinds of herbs and green leafy vegetables.
} 
program was active. In addition to the quantitative household survey, we conducted qualitative interviews with six exporters involved in the program in order to find out more about their motivation to adopt GlobalGAP and their costs and benefits of complying with the standard.

\subsection{Perceived benefits and costs of GlobalGAP adoption}

The decision of farmers and exporters to adopt GlobalGAP depends on (1) the expected benefits of adoption, (2) the costs of compliance and (3) the capacity to implement the standard. The capacity of farmers and exporters is influenced by firm or farm size, asset ownership, human capital, access to information and services, and access to NGO, donor or company assistance (Reardon et al., 2009, Henson et al., 2011).

Qualitative interviews conducted with exporters involved in the 'Food Safety in FFV' program revealed their main motivations and challenges faced with respect to GlobalGAP implementation. Targeting markets of Japan and the EU, the exporters were mainly interested in securing and enhancing access to these demanding markets and building trust with their buyers. One exporter emphasized that adoption of the GlobalGAP standard "makes it easier to sell to more lucrative marketing channels, such as supermarkets, where prices are more stable and quantities are fixed”. While this reflects exporters' motivation to actively improve their access to remunerative and reliable marketing channels, often the incentive came from within the current marketing relationship: many exporters stated that buyers have started to require the GlobalGAP standard and that they perceived GlobalGAP adoption as a measure to increase their buyers’ trust.

On the other hand, the exporters identified the costs of implementation, the lack of qualified staff for the management of the QMS, and time constraints of the QMS members as the major constraints to GlobalGAP adoption. Moreover, exporters stated that there is a lack of knowledge about GlobalGAP on the growers' side and that it is very difficult to persuade farmers that compliance with standards is a necessity because they can still sell on the local market where prices are usually lower, but food safety requirements are basically absent.

Data on the farmers' perceived benefits and challenges of GlobalGAP adoption is available as qualitative information from our household survey. The adopters' perceptions of the benefits that result from GlobalGAP compliance are shown in Table 1. The most important motivation 
for farmers to adopt the standard that was stated by $93 \%$ of the adopters is to increase the quality of the produce. Closely related to the issue of quality are enhanced management practices that $83 \%$ of the adopters see as a benefit of GlobalGAP. Enhanced management practices can result from working according to the standard guidelines and might contribute to quality increases.

Health also seems to be a major issue for farmers and $85 \%$ of the farmers think that GlobalGAP compliance will lead to improvements in the family's and farm workers' health. Pesticide poisoning is a major problem in Thailand. Farmers tend to overuse chemicals and many farmers continue to use banned chemicals which are extremely hazardous. In addition, workers applying pesticides usually do not wear adequate protective clothing (Chunyanuwat, 2005, Roitner-Schobesberger et al., 2008, Shepard, 2006). A study on the impact of GlobalGAP adoption on farmers' health in Kenya has shown that adoption of the standard can decrease the costs for illnesses by 50-60\% (Asfaw et al., 2010). Another important motivation for farmers to adopt GlobalGAP that was stated by $81 \%$ of the adopters is the expected benefit of reduced expenditures on chemicals. This is questionable, however, since the chemicals that adopters are allowed to use are usually more expensive than ordinary chemicals (Asfaw et al., 2009a). GlobalGAP certified producers are only allowed to use chemicals that are registered in the country of use for the target crop (FoodPLUS, 2011b).

Other perceived benefits are mostly related to marketing issues, e.g. to make it easier to find a buyer, to improve access to high-value markets and to increase bargaining power. About $54 \%$ of the GlobalGAP adopters state that their buyer requires GlobalGAP. In some cases, farmers are offered a purchase guarantee (68\%) and/or a price premium (47\%) if they succeed to adopt the standard. The exporters involved in the program stated that the GlobalGAP adopters will not gain immediate benefits from compliance, but will receive long-term benefits. Farmers were promised that exporters would purchase higher volumes from them. In addition, through quality increases they might be able to obtain better prices and thus further increase their incomes. 
Table 1: Adopters perception of the benefits of GlobalGAP

\begin{tabular}{lcc}
\hline Farmers' motivation to adopt GlobalGAP & $\begin{array}{c}\text { Number of } \\
\text { farmers }\end{array}$ & $\mathbf{\%}$ \\
\hline Increase the quality of the produce & $\mathbf{5 5}$ & $\mathbf{9 3}$ \\
Enhance family's and farm workers' health & $\mathbf{5 0}$ & $\mathbf{8 4}$ \\
Make finding buyers easier & $\mathbf{4 9}$ & $\mathbf{8 3}$ \\
Enhance management practices & $\mathbf{4 9}$ & $\mathbf{8 3}$ \\
Decrease costs for chemicals & $\mathbf{4 8}$ & $\mathbf{8 1}$ \\
Increase access to high-value markets & $\mathbf{4 4}$ & $\mathbf{7 5}$ \\
Buyer offered a purchase guarantee & $\mathbf{4 0}$ & $\mathbf{6 8}$ \\
Buyer required GlobalGAP & $\mathbf{3 2}$ & 54 \\
Enhance reputation & $\mathbf{3 1}$ & 53 \\
Buyer offered a price premium & $\mathbf{2 8}$ & $\mathbf{4 7}$ \\
Enhance bargaining power & $\mathbf{2 8}$ & $\mathbf{4 7}$ \\
\hline N=59, multiple options possible & & \\
Source: Own data & &
\end{tabular}

It has to be noted, however, that within the 'Food Safety in FFV' initiative, only 33\% of farmers who initially participated in the program successfully adopted GlobalGAP. The farmers' reasons for their failure to adopt are presented in Table 2. More than $50 \%$ of farmers stated that the investment costs were too high, while 35\% complained that there is no price premium for certified produce and that they did not understand the standard requirements. The additional workload was a problem for $18 \%$ of the non-adopters while $12 \%$ said they were not able to implement the standard on time.

Table 2: Farmers' reasons for failed GlobalGAP implementation

\begin{tabular}{lcc}
\hline Reasons for not adopting GlobalGAP & $\begin{array}{c}\text { Number of } \\
\text { farmers }\end{array}$ & $\mathbf{\%}$ \\
\hline The investment costs were too high & $\mathbf{9}$ & $\mathbf{5 3}$ \\
Absence of a price premium for certified produce & $\mathbf{6}$ & $\mathbf{3 5}$ \\
I didn't understand the standard requirements & $\mathbf{6}$ & $\mathbf{3 5}$ \\
The additional workload was too high & $\mathbf{3}$ & $\mathbf{1 8}$ \\
I was not able to implement the standard on time & $\mathbf{2}$ & $\mathbf{1 2}$ \\
Record keeping was too difficult & $\mathbf{1}$ & $\mathbf{6}$ \\
My buyer decided that I was not ready yet & $\mathbf{1}$ & $\mathbf{6}$ \\
There was not enough support available & $\mathbf{1}$ & $\mathbf{6}$ \\
I changed my mind and decided not to implement the standard & $\mathbf{1}$ & $\mathbf{6}$ \\
\hline N = 17, multiple options possible & & \\
Source: Own data & &
\end{tabular}

The costs of compliance with GlobalGAP can be divided into non-recurrent and recurrent costs. Non-recurrent costs are initial investment costs that are incurred in order to achieve compliance, such as the costs for physical upgrading, initial trainings and the development and establishment of new procedures and management systems. Recurrent costs, in contrast, are costs that have to be incurred on a regular basis and include the additional costs for laboratory analyses, management and annual certification costs. While the non-recurrent costs are one of the main barriers to standard adoption, the recurrent costs are especially important 
when looking at the sustainability of standard adoption (Chemnitz et al., 2007, Jaffee et al., 2005).

In the 'Food Safety in FFV' development program, training and consultancy costs were to a large part taken over by the donor while exporters and farmers had to incur the remaining costs. In the exporter-managed groups, most investments were covered by the companies. The exporters' perception is that farmers are not willing to adopt if they have to invest in the standard. In the farmer- and donor-managed groups, all farm-level investments had to be incurred by the farmers themselves.

We present a case study of an exporter-managed asparagus farmer group with 22 members to demonstrate how the non-recurrent and recurrent costs of compliance are shared between a donor, an exporter, a collector and farmers. The group adopted GlobalGAP in 2007 within the 'Food Safety in FFV' program and is led by a collector who acts as an intermediary between the exporter and the farmers. All members of the group can be classified as small-scale farmers; the average certified area per farmer is only 0.3 ha. Table 3 shows in detail which investments had to be made in order to adopt GlobalGAP and who incurred the costs. The initial investment costs in the exporter-managed asparagus group can be divided into three broad categories: (1) costs for trainings and training materials, (2) costs for farmer and QMS team identification, provision of documents to farmers, on-farm trainings and monitoring, and (3) costs for farm equipment and farm infrastructure. In total, the non-recurrent costs that had to be covered by the group were USD $27,120^{28}$ resulting in an average amount of USD 1233 per farmer. The exporter incurred with 56\% the largest share of the investment costs followed by the donor with 33\%. The collector covered a considerable $7 \%$ of the non-recurrent costs, mostly for farm infrastructure and farm equipment. Farmers only had to cover the remaining investment costs of USD 49 per farmer on the average.

\footnotetext{
${ }^{28}$ The exchange rate at time of data collection from March to May 2008 was approx. 31.25 Thai Baht/ 1 USD.
} 
Table 3: Distribution of non-recurrent costs of compliance with GlobalGAP

- Case study of an exporter-managed asparagus farmer group in Thailand -

\begin{tabular}{|c|c|c|c|c|c|c|}
\hline \multirow{2}{*}{ Investment items } & \multicolumn{5}{|c|}{ GlobalGAP investment costs in USD } & \multirow{2}{*}{$\begin{array}{l}\text { Share } \\
\text { in \% }\end{array}$} \\
\hline & Donor & Exporter & Collector & Farmers & Total & \\
\hline $\begin{array}{l}\text { Trainings \& training materials } \\
\text { (total costs) }\end{array}$ & 2,790 & 8,192 & 176 & $\mathbf{0}$ & 11,158 & 41.1 \\
\hline $\begin{array}{l}\text { Trainings (train-the-trainer seminars, } \\
\text { QMS team \& farmer trainings) }\end{array}$ & 0 & 7,712 & 0 & 0 & 7,712 & 28.4 \\
\hline $\begin{array}{l}\text { Development of training materials, } \\
\text { translations, administration }\end{array}$ & 2,790 & 480 & 0 & 0 & 3,270 & 12.0 \\
\hline Transportation costs (trainings) & 0 & 0 & 176 & 0 & 176 & 0.6 \\
\hline $\begin{array}{l}\text { On-farm trainings \& monitoring, } \\
\text { documents, farmer/QMS team } \\
\text { identification (total costs) }\end{array}$ & 6,196 & 1,808 & $\mathbf{0}$ & $\mathbf{0}$ & 8,003 & 29.5 \\
\hline $\begin{array}{l}\text { Assistance with monitoring and } \\
\text { improving the performance of the } \\
\text { farmers group }\end{array}$ & 6,196 & 192 & 0 & 0 & 6,388 & 23.6 \\
\hline $\begin{array}{l}\text { Preparation and provision of } \\
\text { documents, forms and a general file } \\
\text { for each farmer }\end{array}$ & 0 & 1,408 & 0 & 0 & 1,408 & 5.2 \\
\hline $\begin{array}{l}\text { Identifying the farmers in the } \\
\text { group/initial farmer survey, } \\
\text { identifying QMS members }\end{array}$ & 0 & 208 & 0 & 0 & 208 & 0.8 \\
\hline $\begin{array}{l}\text { Farm infrastructure \& farm } \\
\text { equipment (total costs) }\end{array}$ & $\mathbf{0}$ & 5,040 & 1,838 & 1,080 & 7,958 & 29.3 \\
\hline $\begin{array}{l}\text { Preparation of farm infrastructure, } \\
\text { provision of protective clothing }\end{array}$ & 0 & 5,040 & 0 & 0 & 5,040 & 18.6 \\
\hline Collecting houses, fire extinguisher & 0 & 0 & 1,312 & 0 & 1,312 & 4.8 \\
\hline Toilets and hand washing facilities & 0 & 0 & 157 & 693 & 850 & 3.1 \\
\hline $\begin{array}{l}\text { Farm equipment (containers to store } \\
\text { chemicals and protective clothing, } \\
\text { chemical mixing area, plastic sheets } \\
\text { for produce handling areas) }\end{array}$ & 0 & 0 & 106 & 387 & 493 & 1.8 \\
\hline $\begin{array}{l}\text { First aid kits, waste bins, plot } \\
\text { markers }\end{array}$ & 0 & 0 & 264 & 0 & 264 & 1.0 \\
\hline Total investment costs & 8,986 & 15,040 & 2,014 & 1,080 & 27,120 & \\
\hline Share of investment costs & $33.1 \%$ & $55.5 \%$ & $7.4 \%$ & $4 \%$ & $100 \%$ & \\
\hline
\end{tabular}

The recurrent costs of compliance in the asparagus group were almost as high as the nonrecurrent costs and amounted to USD 13,254 during the first year of certification (see Table 4). The exporter incurred $88 \%$ of the recurrent costs while the collector took over $8 \%$ and farmers only had to pay the remaining $5 \%$. The major share of costs had to be incurred for the external audit, followed by the costs for laboratory analyses, internal inspections, internal audits and the operation of the QMS. Farmers only had to pay USD 29 per capita for the replacement of protective clothing, first aid kits, disinfectants and soap.

The total recurrent costs of USD 602 per farmer are substantial and were assessed as economically not feasible by the exporter. Transferring additional costs to farmers was also not possible because the costs would have represented a significant part of their revenue. Due 
to these high recurrent costs, the exporter decided to discontinue GlobalGAP certification in this group. This case study is thus an example of a group where a certain size threshold was not met and the costs outweighed the benefits of adoption. However, since 2008 the costs for the external audit in Thailand have approximately been halved, ${ }^{29}$ so that under current circumstances continued certification might have been viable for the group.

Table 4: Annual recurrent costs of compliance with GlobalGAP

- Case study of an exporter-managed asparagus farmer group in Thailand -

\begin{tabular}{|c|c|c|c|c|c|}
\hline \multirow{2}{*}{ Cost factor } & \multicolumn{4}{|c|}{ Recurrent costs for GlobalGAP in USD } & \multirow{2}{*}{$\begin{array}{c}\text { Share in } \\
\%\end{array}$} \\
\hline & Exporter & Collector & Farmers & Total & \\
\hline Certification and external audit & 4,992 & 0 & 0 & 4,992 & 37.7 \\
\hline $\begin{array}{l}\text { Annual refresher trainings } \\
\text { (farmers and QMS) }\end{array}$ & 2,528 & 0 & 0 & 2,528 & 19.1 \\
\hline $\begin{array}{l}\text { Laboratory analyses } \\
\text { (pesticide residue, water and soil analyses) }\end{array}$ & 2,472 & 0 & 0 & 2,472 & 18.7 \\
\hline $\begin{array}{l}\text { Internal inspections \& audits } \\
\text { (farmers, QMS, produce handling sites) }\end{array}$ & 832 & 0 & 0 & 832 & 6.3 \\
\hline Operation of the QMS & 800 & 0 & 0 & 800 & 6.0 \\
\hline $\begin{array}{l}\text { Transportation (farmers to trainings, farm } \\
\text { advice, inspections/audits) }\end{array}$ & 0 & 768 & 0 & 768 & 5.8 \\
\hline Replacement of protective clothing & 0 & 0 & 324 & 324 & 2.4 \\
\hline Refill first aid kits, disinfectant and soap & 0 & 0 & 317 & 317 & 2.4 \\
\hline Health checks for staff working with pesticides & 0 & 117 & 0 & 117 & 0.9 \\
\hline $\begin{array}{l}\text { Record keeping forms, } \\
\text { replacement of posters \& signs }\end{array}$ & 0 & 104 & 0 & 104 & 0.8 \\
\hline Total recurrent costs & 11,624 & 989 & 641 & 13,254 & 100 \\
\hline Share of the recurrent costs & 87.7 & 7.5 & 4.8 & 100 & 100 \\
\hline
\end{tabular}

Source: Own data

\subsection{Explaining GlobalGAP adoption}

GlobalGAP adoption in this study is only observed for farmers who have participated in the development program 'Food Safety in FFV'. Hence, farmers have to make two subsequent decisions: whether or not to participate in the development program, and if they do so, whether or not to obtain a GlobalGAP certificate. We assume that a farmer will choose to participate in the development program and/or adopt the standard if the expected benefits are greater than the expected costs. The two decisions, to participate in the 'Food Safety in FFV' program and to adopt the GlobalGAP standard, are expected to be determined by similar variables because the program supports farmers in achieving GlobalGAP certification. Nonparticipant farmers were sampled in the villages were the development program was active

\footnotetext{
${ }^{29}$ The German International Cooperation (GIZ) estimates that currently the cost for GlobalGAP Option 2 certification in Thailand for a group of 10 farmers (with a total of 10 hectares of land to be certified) is approximately 2000 USD.
} 
and hence each interviewed farmer had an equal chance to participate in the initiative. Factors that might influence the decisions can be divided into three broad categories: household characteristics (age, education and experience, labor availability, household wealth), farm characteristics (land tenure, farm size, access to irrigation), and access related variables (access to information and extension services, membership in farmer groups, distance to the next larger city, support by donors and downstream actors). The conceptual framework for the empirical model is presented in Figure 2.

Figure 2: Conceptual framework

\section{- Participation in the 'Food Safety in FFV' program and GlobalGAP adoption -}

Determinants:

- Household and farm characteristics

- $\quad$ Access to information

- $\quad$ Access to extension services and trainings

- $\quad$ Membership in farmer groups

- $\quad$ Previous involvement in high-value supply chains

- $\quad$ Support by donors and exporters

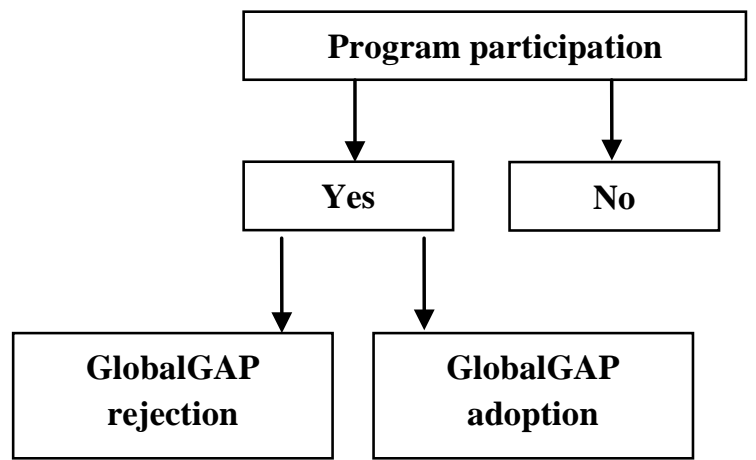

Source: Own illustration

Since GlobalGAP adoption in this study is an outcome of participation in the development program 'Food Safety in FFV', an econometric model has to be specified that takes into account a possible sample selection bias. Those farmers might join a development program on GlobalGAP certification, who have a greater chance to successfully adopt the standard than randomly selected farmers (Maddala, 1983). As a result, the same unobservable factors that influence program participation might also influence GlobalGAP adoption. In order to control for potential selection bias, we employ a bivariate probit model with sample selection (van de Ven and van Praag, 1981). The bivariate probit model with sample selection allows for two separate probit models with correlated error terms. If error terms are significantly correlated, this indicates the existence of a self-selection bias. In the probit model, we assume that there is an underlying relationship between an unobserved, latent variable and the observed outcome. The specification of the bivariate probit model with sample selection, adapted from Greene (2008), is given by: 
Selection equation: $y_{i 1}^{*}=\boldsymbol{\beta}_{1}^{\prime} \boldsymbol{x}_{i 1}+\epsilon_{i 1}, y_{i 1}=1$ if $y_{i 1}^{*}>0, y_{i 1}=0$ if $y_{i 1}^{*}<0$

Outcome equation: $y_{i 2}^{*}=\boldsymbol{\beta}_{1}^{\prime} \boldsymbol{x}_{i 2}+\epsilon_{i 2}, y_{i 2}=1$ if $y_{i 2}^{*}>0, y_{i 2}=0$ if $y_{i 2}^{*}<0$

$$
\begin{gathered}
\epsilon_{i 1}, \epsilon_{i 2} \sim \operatorname{BVN}(0,0,1,1, \rho), \operatorname{Var}\left[\epsilon_{i 1}\right]=\operatorname{Var}\left[\epsilon_{i 2}\right]=1, \\
\operatorname{Cov}\left[\epsilon_{i 1}, \epsilon_{i 2}\right]=\rho
\end{gathered}
$$$$
\left(y_{i 2}, x_{i 2} \text { is observed only when } y_{i 1}=1\right) \text {, }
$$

where $y_{i}^{*}$ are unobserved or latent variables, $\boldsymbol{\beta}_{j}^{\prime}$ are parameter vectors and $\boldsymbol{x}_{i}$ are vectors of exogenous independent variables. The error terms $\epsilon_{i 1}, \in_{i 2}$ have a bivariate normal distribution with zero mean, unit variance and correlation $\rho$. The $y_{i}$ are dichotomous outcome variables and in the GlobalGAP adoption model,

$y_{i 1}=1$ if the farmer $i$ participates in the development program, 0 otherwise

$y_{i 2}=1$ if the farmer $i$ adopts GlobalGAP, 0 otherwise.

In the selection equation, $y_{i 1}^{*}$ represents the utility that the $i^{\text {th }}$ farmer receives from taking part in the development program, and in the outcome equation, $y_{i 2}^{*}$ represents the utility from GlobalGAP adoption. We assume that if $y_{i}^{*}>0$, the observed outcome will be program participation/GlobalGAP adoption $\left(y_{i}=1\right)$. However, $y_{i 2}, \boldsymbol{x}_{i 2}$ can only be observed if the selection condition, participation in the development program, is met (Greene, 2008).

We use probability weights in the estimation to correct for the overrepresentation of 'Food Safety in FFV' program participants in our sample. The weight is calculated as the inverse of the sampling fraction, i.e. the total number of households in the relevant population divided by the number of sampled households drawn from that population.

We draw on the existing literature on the adoption of standards (Asfaw et al., 2009b, Okello, 2005) and on the adoption of agricultural innovations (e.g. Feder et al., 1985, Ghadim and Pannell, 1999) to derive hypotheses about the expected effects of the independent variables on GlobalGAP adoption. Regarding household characteristics, previous studies have found education to be positively related to standard adoption (Asfaw et al., 2009b, Okello, 2005). The implementation of GlobalGAP requires a high willingness to learn because a thorough knowledge of good agricultural practices has to be acquired. Complying with the record keeping requirements and running the QMS is likely to be especially difficult for less educated farmers. To reflect the high knowledge intensity of the standard, we include a 
dummy variable in the model that equals one if at least one member of the household has graduated from college. In addition, we include a variable on the years of experience in the production of fruit and vegetables $(\mathrm{F} \& \mathrm{~V}),{ }^{30}$ as well as two dummy variables on whether the farmer owns a Q-GAP ${ }^{31}$ certificate and whether he sold to an exporter or supermarket prior to participation in the development program. These variables capture our expectation that farmers with more experience in relevant areas face fewer difficulties in understanding GlobalGAP requirements. We therefore expect these experience-related variables to have a positive impact on the adoption of standards. Moreover, we expect that younger farmers are more innovative and therefore more likely to adopt the standard.

The requirements of the GlobalGAP standard are not only complex, but they are also time intensive. Several trainings are necessary to acquire the knowledge for GlobalGAP adoption and farm infrastructure and processes have to be upgraded to meet standard requirements. Hence, the availability of family labor is expected to be positively related to GlobalGAP adoption. On the other hand, the number of dependants in the household and the number of family members participating in off-farm work are hypothesized to have a negative influence on adoption given that family labor is absorbed by other activities.

Furthermore, we expect household wealth to have a positive impact on standard adoption. Wealthier farmers are more likely to have access to credits and to be able to finance the costs of compliance with GlobalGAP. To capture the effects of household wealth we include variables on the number of household assets and vehicles owned, as well as on livestock ownership. In addition we include a variable on the ownership of a land title, which reduces the uncertainty of investments and is therefore also expected to have a positive effect on standard adoption. For some of the investments associated with GlobalGAP there is likely to be significant economies of scale. For example, the costs for the external audit are relatively higher for smaller and less productive farms than for larger farms, given that these are fixed costs (Jaffee et al., 2005). Therefore, we expect that farm size, the share of the cultivated area on which $\mathrm{F} \& \mathrm{~V}$ are grown, and the share of the area under $\mathrm{F} \& \mathrm{~V}$ that is irrigated by means of sprinkler or drip irrigation (irrigation intensity) increase the likelihood of adoption (Okello, 2005, Hernandez et al., 2007).

\footnotetext{
${ }^{30}$ The variable only includes the products considered for GlobalGAP certification.

${ }^{31}$ Q-GAP is a voluntary standard for good agricultural practices developed by the Thai government in 2004, which is required by several high-end domestic retailers and also plays a role in the export sector. However, the private sector criticizes it for lack of credibility and insufficient scope (Sardsud, 2007).
} 
Finally, we expect that support by donors and exporters positively influences the likelihood of standard adoption. We account for this by including a variable on the number of agricultural trainings subjects attended by the farmer. In addition, we include two dummy variables that capture whether the QMS is managed by the donor or by the exporter, respectively. In both cases we expect that farmers receiving this managerial support will be more likely to achieve standard compliance. Moreover, we include a number of control variables related to access to information, such as membership in groups (number), ${ }^{32}$ access to public extension services, mobile phone ownership, and distance to the provincial capital, which are expected to be crucial for the adoption decision. Finally, we add a dummy variable for specialization in vegetable cultivation to account for structural differences between fruit and vegetable farmers.

In the program participation equation, we additionally include the variable previous contact to training staff of the 'Food Safety in FFV' initiative. Those farmers who have already been in contact with important stakeholders of the development program are expected to be more likely to participate in the 'Food Safety in FFV' initiative. However, since previous projects did not focus on GlobalGAP implementation, we do not expect this variable to have a direct influence on standard adoption. In contrast, the variables 'exporter-managed QMS' and 'donor-managed QMS' are excluded from the program participation equation because they are an outcome of the 'Food Safety in FFV' initiative.

\subsubsection{Descriptive statistics}

In Table 5, using the student $t$-test and the Pearson's chi square test, we compare participants in the 'Food Safety in FFV' program to non-participants, and within the group of the program participants, we compare adopters to non-adopters. Furthermore, to find out how group means differ between adopters in the farmer-managed, donor-managed and exporter-managed groups we use Bonferroni and chi square tests.

Comparing program participants to non-participants, we observe that participants are significantly younger and better educated. Moreover, they irrigate a significantly higher share of their land under $\mathrm{F} \& \mathrm{~V}$ with drip and sprinkler irrigation systems. As expected, participants are members in a higher number of groups reflecting their propensity to cooperate and join group activities. In addition, the share of farmers who sold to an exporter or supermarket

\footnotetext{
${ }^{32}$ It is important to note that the variable does not include the groups formed for GlobalGAP Option 2 group certification.
} 
before program participation, the share of farmers owning a Q-GAP certificate and the share of farmers with previous contact to training staff of the 'Food Safety in FFV' initiative is significantly higher among participants. Contrary to our expectations, the share of cultivated land on which $\mathrm{F} \& \mathrm{~V}$ are produced and the number of training subjects attended ${ }^{33}$ are significantly lower among participants.

The comparison between adopters and non-adopters also yields interesting results. Adopters are significantly better educated. While $45 \%$ of the adopters have at least one college graduate in the household, only $27 \%$ of non-adopter households do so. In addition, adopters are endowed with significantly more female adults in the household, have fewer dependants in the family, and own more household assets. While farm size does not differ significantly between adopters and non-adopters, adopters irrigate a significantly higher share of their land under F\&V with drip and sprinkler irrigation systems and more often possess a land title. Concerning experience-related variables, the descriptive results show that the share of farmers owning a Q-GAP certificate and the share of farmers who sold to an exporter or supermarket before program participation is significantly higher among GlobalGAP adopters than among non-adopters. Moreover, adopters have better access to information: they live closer to the next provincial capital and they have participated in a significantly higher number of training subjects $^{34}$ than non-adopters. The result that adopters are members in significantly fewer groups might indicate that farmers who are members in several groups are time constrained and/or have other priorities, i.e. they do not fully commit to GlobalGAP adoption.

Finally, we compare the differences between adopters in groups with a farmer-, donor- and exporter-managed QMS. Of the interviewed adopters, 19\% were organized in groups with a farmer-managed QMS, 46\% in groups with a donor-run QMS and 35\% were organized in outgrower schemes where the QMS was run by an exporter. There are significant differences in particular with respect to education, wealth, and farm size between adopters in groups with a farmer-managed QMS on the one hand and adopters with either a donor-run or an exporterrun QMS on the other hand. Concerning education, our results suggest that farmers must be highly educated to run the QMS by themselves. While 72\% of adopters in groups where the QMS is farmer-managed have a college degree, only $44 \%$ of households in the exportermanaged groups and $36 \%$ in the donor-managed group do so. Moreover, adopters in the

\footnotetext{
${ }^{33}$ The variable captures all agricultural training subjects a farmer has attended excluding those that were carried out by the 'Food Safety in FFV' initiative.

${ }^{34}$ The variable captures all agricultural training subjects a farmer has attended including those that were carried out by the 'Food Safety in FFV' initiative.
} 
farmer-managed groups are wealthier than adopters in the other two group types; they own both significantly more household assets and significantly more vehicles. In line with this, we find that farm size is significantly larger among adopters in farmer-managed groups. While adopters in the farmer-managed groups are on average endowed with 11.9 ha of land, adopters in the donor-managed group have 2.7 ha and in the exporter-managed groups 3.0 ha of land. This is likely to be related to the higher investment costs that have to be covered by farmers in farmer-managed groups, which makes certification feasible only for farms that exceed a certain size threshold. In the following analysis we estimate the effect of managerial support from the donor and from the exporter in running the QMS on standard adoption while at the same time controlling for household and farm related variables. 
Table 5: Descriptive statistics

\begin{tabular}{|c|c|c|c|c|c|c|c|}
\hline \multirow[b]{2}{*}{ Description } & \multicolumn{2}{|c|}{$\begin{array}{c}\text { Full sample } \\
(\mathrm{N}=231)\end{array}$} & \multicolumn{2}{|c|}{$\begin{array}{c}\text { Program participants } \\
\qquad(\mathrm{N}=146)\end{array}$} & \multicolumn{3}{|c|}{$\begin{array}{c}\text { Adopters } \\
(\mathrm{N}=96)\end{array}$} \\
\hline & $\begin{array}{c}\text { Program } \\
\text { participants } \\
(\mathrm{N}=146)\end{array}$ & $\begin{array}{c}\text { Non- } \\
\text { participants } \\
(\mathrm{N}=85)\end{array}$ & $\begin{array}{c}\text { Adopters } \\
(\mathrm{N}=97)\end{array}$ & $\begin{array}{l}\text { Non- } \\
\text { adopters } \\
(\mathrm{N}=49)\end{array}$ & $\begin{array}{c}\text { Farmer-run } \\
\text { QMS } \\
(\mathrm{N}=18) \\
\end{array}$ & $\begin{array}{c}\text { Donor-run } \\
\text { QMS } \\
(\mathrm{N}=45)\end{array}$ & $\begin{array}{c}\text { Exporter- } \\
\text { run QMS } \\
(\mathrm{N}=34)\end{array}$ \\
\hline $\begin{array}{l}\text { College graduate in the } \\
\text { household }(\mathrm{Y} / \mathrm{N}) \text { in } \%\end{array}$ & $39.04 * *$ & 24.71 & $45.36^{* *}$ & 26.53 & $72.22^{\mathrm{a}^{* * *} \mathrm{~b}^{*}}$ & $35.56^{\mathrm{a}^{* * *}}$ & $44.12^{\mathrm{b}^{*}}$ \\
\hline Age of the household head & $\begin{array}{c}47.29 * * \\
(10.18)\end{array}$ & $\begin{array}{c}50.81 \\
(11.74)\end{array}$ & $\begin{array}{l}46.93 \\
(9.44)\end{array}$ & $\begin{array}{c}48.02 \\
(11.59)\end{array}$ & $\begin{array}{c}48.56 \\
(12.65)\end{array}$ & $\begin{array}{l}48.11 \\
(6.99)\end{array}$ & $\begin{array}{c}44.50 \\
(10.10)\end{array}$ \\
\hline $\begin{array}{l}\text { No. of female household } \\
\text { members (age 16-65) }\end{array}$ & $\begin{array}{l}1.51 \\
(0.81)\end{array}$ & $\begin{array}{l}1.64 \\
(0.78)\end{array}$ & $\begin{array}{c}1.64 * * * \\
(0.87)\end{array}$ & $\begin{array}{l}1.27 \\
(0.60)\end{array}$ & $\begin{array}{l}1.39 \\
(0.85)\end{array}$ & $\begin{array}{l}1.53 \\
(0.79)\end{array}$ & $\begin{array}{l}1.91 \\
(0.93)\end{array}$ \\
\hline $\begin{array}{l}\text { No. of male household } \\
\text { members (age 16-65) }\end{array}$ & $\begin{array}{l}1.54 \\
(0.76)\end{array}$ & $\begin{array}{l}1.54 \\
(0.97)\end{array}$ & $\begin{array}{l}1.56 \\
(0.82)\end{array}$ & $\begin{array}{l}1.51 \\
(0.65)\end{array}$ & $\begin{array}{l}1.56 \\
(0.98)\end{array}$ & $\begin{array}{l}1.53 \\
(0.69)\end{array}$ & $\begin{array}{l}1.59 \\
(0.89)\end{array}$ \\
\hline $\begin{array}{l}\text { No. of dependants (age } \\
\text { under } 16 \text { and over 65) }\end{array}$ & $\begin{array}{l}1.05 \\
(0.93)\end{array}$ & $\begin{array}{l}1.13 \\
(1.07)\end{array}$ & $\begin{array}{l}0.93 * * \\
(0.86)\end{array}$ & & $\begin{array}{l}1.5^{\mathrm{a}^{* * *}} \\
(0.92)\end{array}$ & $\begin{array}{c}0.60^{\mathrm{a}^{* * * *} \mathrm{c}^{* *}} \\
(0.75)\end{array}$ & $\begin{array}{l}1.06^{\mathrm{c**}} \\
(0.78)\end{array}$ \\
\hline $\begin{array}{l}\text { No. of household } \\
\text { members off-farm work }\end{array}$ & $\begin{array}{c}0.68 \\
(1.02)\end{array}$ & $\begin{array}{c}0.68 \\
(1.01)\end{array}$ & $\begin{array}{c}0.69 \\
(1.04)\end{array}$ & $\begin{array}{c}0.68 \\
(1.00)\end{array}$ & $\begin{array}{c}1.39^{a^{* * *} b^{* *}} \\
(1.38)\end{array}$ & $\begin{array}{c}0.47^{* * * *} \\
(0.89)\end{array}$ & $\begin{array}{l}0.59^{6 * *} \\
(0.86)\end{array}$ \\
\hline $\begin{array}{l}\text { No. of household } \\
\text { assets owned }\end{array}$ & $\begin{array}{l}4.79 \\
(2.86)\end{array}$ & $\begin{array}{c}4.55 \\
(2.37)\end{array}$ & $\begin{array}{l}5.07^{*} \\
(3.10)\end{array}$ & $\begin{array}{c}4.22 \\
(2.22)\end{array}$ & $\begin{array}{c}7.67^{\mathrm{a}^{* * *} \mathrm{~b}^{*}} \\
(3.55)\end{array}$ & $\begin{array}{c}3.47^{\mathrm{a}^{* * * *} \mathrm{c}^{* * *}} \\
(1.39)\end{array}$ & $\begin{array}{c}5.82^{\mathrm{b}^{*} \mathrm{c}^{* * * *}} \\
(3.33)\end{array}$ \\
\hline $\begin{array}{l}\text { No. of vehicles owned } \\
\text { (cars, pick-ups, tractors) }\end{array}$ & $\begin{array}{l}1.31 \\
(1.47)\end{array}$ & $\begin{array}{l}1.32 \\
(1.15)\end{array}$ & $\begin{array}{l}1.42 \\
(1.64)\end{array}$ & $\begin{array}{l}1.08 \\
(1.02)\end{array}$ & $\begin{array}{l}2.89^{\mathrm{a}^{* * *} \mathrm{~b}^{* * * *}} \\
(2.03)\end{array}$ & $\begin{array}{c}0.91^{\mathrm{a}^{* * *}} \\
(0.87)\end{array}$ & $\begin{array}{l}1.32^{\mathrm{b}^{* * *}} \\
(1.79)\end{array}$ \\
\hline Land title $(\mathrm{Y} / \mathrm{N})$ in \% & 67.81 & 63.53 & $73.20^{* *}$ & 58.14 & $61.11^{\mathrm{a}^{*}}$ & & 67.65 \\
\hline Total farm size in ha & $\begin{array}{c}4.31 \\
(7.03)\end{array}$ & $\begin{array}{c}3.04 \\
(5.14)\end{array}$ & $\begin{array}{c}4.53 \\
(8.24)\end{array}$ & $\begin{array}{c}3.88 \\
(3.66)\end{array}$ & $\begin{array}{l}11.93^{\mathrm{a}^{* * * *} \mathrm{~b}^{* * *}} \\
\quad(15.43)\end{array}$ & $\begin{array}{c}2.72^{\mathrm{a}^{* * *}} \\
(1.94)\end{array}$ & $\begin{array}{l}3.01^{\mathrm{b} * * *} \\
(5.73)\end{array}$ \\
\hline $\begin{array}{l}\text { Share of total cultivated } \\
\text { area under F\&V }\end{array}$ & $\begin{array}{c}0.72^{* * *} \\
(0.33)\end{array}$ & $\begin{array}{c}0.88 \\
(0.25)\end{array}$ & $\begin{array}{c}0.69 \\
(0.34)\end{array}$ & $\begin{array}{c}0.77 \\
(0.30)\end{array}$ & $\begin{array}{l}79.15^{\mathrm{a}^{* * *}} \\
(27.19)\end{array}$ & $\begin{array}{l}47.07^{a^{* * * *} c^{* * *}} \\
(29.83)\end{array}$ & $\begin{array}{l}91.61^{\mathrm{c} * * *} \\
(24.47)\end{array}$ \\
\hline $\begin{array}{l}\text { Share of area under F\&V } \\
\text { with sprinkler/drip irrigation }\end{array}$ & $\begin{array}{l}0.83 * * \\
(0.35)\end{array}$ & $\begin{array}{c}0.68 \\
(0.44)\end{array}$ & $\begin{array}{l}0.90 * * * \\
(0.28)\end{array}$ & $\begin{array}{c}0.69 \\
(0.44)\end{array}$ & $\begin{array}{c}0.89 \\
(0.25)\end{array}$ & $\begin{array}{c}0.94 \\
(0.23)\end{array}$ & $\begin{array}{c}0.85 \\
(0.36)\end{array}$ \\
\hline Years of experience in & 13.95 & 12.08 & 13.56 & 14.73 & $12.44^{\mathrm{a}^{* * *} \mathrm{~b}}$ & $18.42^{\mathrm{a}^{* * * c^{*}}}$ & $7.71^{\mathrm{b}^{* * * \mathrm{c}^{* * *}}}$ \\
\hline & & & & & $(6.56)$ & & \\
\hline Livestock (Y/N) in \% & 10.96 & & 10.31 & & $27.78^{\mathrm{a}^{\mathrm{a} * *}}$ & $2.22^{\mathrm{a}^{* * * *} \mathrm{c}^{*}}$ & $11.76^{\mathrm{c}^{*}}$ \\
\hline Vegetables $(\mathrm{Y} / \mathrm{N})$ in \% & $29.45^{* *}$ & 43.53 & $39.18^{* * *}$ & 10.20 & $55.56^{a^{* * *} b^{* *}}$ & $0.00^{\mathrm{a}^{* * *} \mathrm{c} * * *}$ & $82.35^{b^{* *} c^{* * *}}$ \\
\hline Q-GAP $(\mathrm{Y} / \mathrm{N})$ in \% & $80.14^{* * *}$ & 27.06 & $89.69 * * *$ & 61.22 & $72.22^{\mathrm{a}^{* *} \mathrm{~b}^{* * *}}$ & $91.11^{\mathrm{a}^{* *}}$ & $97.06^{\mathrm{b}^{* * *}}$ \\
\hline $\begin{array}{l}\text { Exporter/supermarket } \\
\text { supplier (Y/N) in \% }\end{array}$ & $39.73^{* *}$ & 24.71 & $48.45^{* * *}$ & 22.45 & $38.89^{\mathrm{b}^{* *} \mathrm{~b} * * *}$ & $15.56^{\mathrm{a}^{* * c^{* * *}}}$ & $97.06^{\mathrm{b***} \mathrm{c}^{* * *}}$ \\
\hline Public extension $(\mathrm{Y} / \mathrm{N})$ in \% & 20.55 & 15.29 & & 22.45 & $27.78^{\mathrm{a}^{* * *}}$ & $2.22^{\mathrm{a}^{* * *} \mathrm{c}^{* * *}}$ & $38.24^{4^{* * *}}$ \\
\hline $\begin{array}{l}\text { No. group memberships } \\
\text { (excl. standard) }\end{array}$ & $\begin{array}{c}0.99 * * \\
(0.66)\end{array}$ & & & & & $\begin{array}{l}1.33^{\mathrm{a}^{* * * *} \mathrm{c}^{* * * *}} \\
(0.64)\end{array}$ & $\begin{array}{l}0.71^{\mathrm{c***}} \\
(0.68)\end{array}$ \\
\hline Mobile phone $(\mathrm{Y} / \mathrm{N})$ in \% & 95.89 & 94.12 & 97.96 & 94.85 & 100 & 95.56 & 91.18 \\
\hline $\begin{array}{l}\text { Distance to the next } \\
\text { provincial capital }(\mathrm{km})\end{array}$ & $\begin{array}{c}37.39 \\
(23.62)\end{array}$ & $\begin{array}{c}41.71 \\
(31.25)\end{array}$ & $\begin{array}{c}32.60 * * * \\
(17.85)\end{array}$ & $\begin{array}{c}46.85 \\
(30.17)\end{array}$ & $\begin{array}{l}31.09 \\
(20.46)\end{array}$ & $\begin{array}{l}34.71 \\
(3.67)\end{array}$ & $\begin{array}{c}30.61 \\
(26.11)\end{array}$ \\
\hline $\begin{array}{l}\text { Training subjects attended } \\
\text { excl. those by the program }\end{array}$ & $\begin{array}{l}0.51^{* *} \\
(2.48)\end{array}$ & $\begin{array}{l}1.45 \\
(3.94)\end{array}$ & $\mathrm{n} / \mathrm{a}$ & $\mathrm{n} / \mathrm{a}$ & $\mathrm{n} / \mathrm{a}$ & $\mathrm{n} / \mathrm{a}$ & $\mathrm{n} / \mathrm{a}$ \\
\hline $\begin{array}{l}\text { Training subjects attended } \\
\text { incl. those by the program }\end{array}$ & $\mathrm{n} / \mathrm{a}$ & n/a & $\begin{array}{l}12.36^{* *} \\
(7.61)\end{array}$ & $\begin{array}{c}8.98 \\
(8.33)\end{array}$ & $\begin{array}{l}12.67^{\text {*** b b** }} \\
\quad(6.76)\end{array}$ & $\begin{array}{c}17.69^{\mathrm{a}^{* * * *} \mathrm{c}^{* * *}} \\
(3.95)\end{array}$ & $\begin{array}{l}5.15^{\mathrm{b}^{* * *} \mathrm{c}^{* * *}} \\
(5.64)\end{array}$ \\
\hline QMS farmer-run in \% & n/a & $\mathrm{n} / \mathrm{a}$ & $18.56^{* *}$ & & $\mathrm{n} / \mathrm{a}$ & $\mathrm{n} / \mathrm{a}$ & $\mathrm{n} / \mathrm{a}$ \\
\hline QMS donor-run in \% & $\mathrm{n} / \mathrm{a}$ & $\mathrm{n} / \mathrm{a}$ & 46.39 & 34.69 & $\mathrm{n} / \mathrm{a}$ & $\mathrm{n} / \mathrm{a}$ & $\mathrm{n} / \mathrm{a}$ \\
\hline QMS exporter-run in \% & $\mathrm{n} / \mathrm{a}$ & n/a & 35.05 & 30.61 & $\mathrm{n} / \mathrm{a}$ & $\mathrm{n} / \mathrm{a}$ & $\mathrm{n} / \mathrm{a}$ \\
\hline $\begin{array}{l}\text { Previous contact to training } \\
\text { staff }(\mathrm{Y} / \mathrm{N}) \text { in \% }\end{array}$ & $37.67 * * *$ & 9.41 & $\mathrm{n} / \mathrm{a}$ & n/a & $\mathrm{n} / \mathrm{a}$ & $\mathrm{n} / \mathrm{a}$ & $\mathrm{n} / \mathrm{a}$ \\
\hline
\end{tabular}

Notes: Mean values are shown. For continuous variables, standard deviations are shown in parentheses.

Statistical significance at the $1 \%(* * *), 5 \%(* *)$ and $10 \%\left({ }^{*}\right)$ levels.

${ }^{a}$ Difference statistically significant between adopters in the farmer-run groups and donor-run groups.

${ }^{\mathrm{b}}$ Difference statistically significant between adopters in the farmer-run groups and the exporter-run groups.

${ }^{\mathrm{C}}$ Difference statistically significant between adopters in the donor-run groups and the exporter-run groups.

${ }^{\mathrm{d}}$ Refrigerators, washing machines, microwaves, TVs, air cons, satellite dishes, CD/DVD Players.

Source: Own data 


\subsubsection{Results of the adoption model and discussion}

Table 6 shows the results of the bivariate probit model. The coefficients show the direction of the impact of the explanatory variables on program participation and GlobalGAP adoption.

Table 6: Bivariate probit model estimates - Development program participation and GlobalGAP adoption -

\begin{tabular}{|c|c|c|c|c|}
\hline \multirow[t]{2}{*}{ Variable } & \multicolumn{2}{|c|}{$\begin{array}{l}\text { Program participation } \\
\qquad \mathrm{N}=231\end{array}$} & \multicolumn{2}{|c|}{$\begin{array}{l}\text { GlobalGAP adoption } \\
\qquad \mathrm{N}=146\end{array}$} \\
\hline & Coefficient & Standard error & Coefficient & Standard error \\
\hline College graduate (dummy) & $0.814^{* *}$ & 0.338 & $2.217^{* * *}$ & 0.584 \\
\hline Age of the household head & -0.010 & 0.012 & $-0.065 * * *$ & 0.021 \\
\hline No. female household members & -0.224 & 0.176 & 0.436 & 0.271 \\
\hline No. male household members & -0.088 & 0.141 & -0.407 & 0.273 \\
\hline Number of dependants & -0.018 & 0.122 & $-0.668 * * *$ & 0.260 \\
\hline No. of members off-farm work & -0.029 & 0.139 & $-0.809 * * *$ & 0.260 \\
\hline Number of household assets & -0.092 & 0.059 & $0.385^{* * *}$ & 0.107 \\
\hline Number of vehicles & $-0.237 *$ & 0.128 & $0.379 *$ & 0.216 \\
\hline Land title (dummy) & $-0.658 * * *$ & 0.262 & 0.111 & 0.361 \\
\hline Farm size (hectare) & -0.006 & 0.028 & $0.088^{*}$ & 0.046 \\
\hline Share of area under F\&V (lagged) & -0.004 & 0.005 & -0.004 & 0.007 \\
\hline Irrigation intensity F\&V (lagged) & $0.575 *$ & 0.302 & $1.808 * * *$ & 0.569 \\
\hline Years of experience in F\&V production & 0.004 & 0.016 & -0.037 & 0.029 \\
\hline Livestock ownership (dummy) & -0.113 & 0.330 & 0.223 & 0.560 \\
\hline Specialization in vegetables (dummy) & $-1.802 * * *$ & 0.425 & 0.514 & 0.752 \\
\hline Q-GAP certificate (dummy) & $1.343^{* * *}$ & 0.295 & -0.296 & 0.492 \\
\hline Exporter/supermarket supplier (dummy) & $0.716 * *$ & 0.320 & $2.731^{* *}$ & 0.679 \\
\hline Public extension (dummy) & -0.005 & 0.328 & -0.538 & 0.423 \\
\hline Membership in number of groups & 0.089 & 0.278 & $-0.767 * * *$ & 0.302 \\
\hline Mobile phone ownership (dummy) & -0.001 & 0.515 & $0.430 * * *$ & 0.755 \\
\hline Distance to provincial capital (km) & -0.004 & 0.005 & $-0.026 * * *$ & 0.010 \\
\hline $\begin{array}{l}\text { Training subjects attended excluding } \\
\text { those by the development program }\end{array}$ & -0.061 & 0.042 & & \\
\hline $\begin{array}{l}\text { Training subjects attended including } \\
\text { those by the development program }\end{array}$ & & & $0.117 * * *$ & 0.031 \\
\hline Previous contact to training staff (dummy) & $1.713^{* * *}$ & 0.339 & & \\
\hline QMS donor-managed (dummy) & & & $3.362 * * *$ & 1.100 \\
\hline QMS exporter-managed (dummy) & & & $1.634 * *$ & 0.772 \\
\hline
\end{tabular}

Log likelihood = - 475.1126

Correlation rho $(\rho)=0.84$

Note: Statistical significance at the $1 \%\left({ }^{* * *}\right), 5 \%(* *)$ and $10 \%(*)$ levels.

Source: Own data

The results show that ceteris paribus the probability to participate in the development program increases if at least one household member has graduated from college, if a larger share of the area under fruit and vegetables is irrigated by means of sprinkler or drip irrigation systems, ${ }^{35}$ if the household owns a Q-GAP certificate, if the household sells to an exporter or supermarket (prior to program participation), and if the household has had previous contact to

\footnotetext{
${ }^{35}$ The area cultivated with fruit and vegetables that is irrigated by means of sprinkler or drip irrigation systems refers to the area before participation in the development program.
} 
training staff of the 'Food Safety in FFV' initiative. The number of vehicles owned and possession of a land title are negatively significant which reflects the aim of the initiative to also include poorer farmers into the program. Given that we do not find evidence for a selection bias in our model presented in Table 6, we can calculate a univariate probit model to estimate GlobalGAP adoption including only the sample of the program participants. Results of the univariate probit model, which are presented in Table 7 , do not deviate much from the results of the outcome regression of the bivariate probit model with sample selection (Table 6) supporting the robustness of our estimation results.

Table 7: Probit model estimates

- The determinants of GlobalGAP adoption -

\begin{tabular}{lccccc}
\hline Variable & Coefficient & $\begin{array}{c}\text { Robust } \\
\text { std. error }\end{array}$ & $\begin{array}{c}\text { Marginal } \\
\text { effects }\end{array}$ & $\begin{array}{c}\text { Robust } \\
\text { std. error }\end{array}$ & Means \\
\hline College graduate (dummy) & $2.131^{* * *}$ & 0.602 & $0.633^{* * *}$ & 0.151 & 0.328 \\
Age of the household head & $-0.064^{* * *}$ & 0.022 & $-0.016^{* * *}$ & 0.005 & 47.657 \\
No. female household members & $0.471^{*}$ & 0.278 & $0.119^{*}$ & 0.069 & 1.390 \\
No. male household members & -0.356 & 0.274 & -0.090 & 0.068 & 1.526 \\
Number of dependants & $-0.687^{* * *}$ & 0.255 & $-0.173^{* * *}$ & 0.061 & 1.180 \\
No. of members off-farm work & $-0.869^{* * *}$ & 0.258 & $-0.218^{* * *}$ & 0.076 & 0.689 \\
Number of household assets & $0.407^{* * *}$ & 0.101 & $0.102^{* * *}$ & 0.027 & 4.507 \\
Number of vehicles & $0.425^{* *}$ & 0.215 & $0.107^{* *}$ & 0.052 & 1.195 \\
Land title (dummy) & 0.227 & 0.355 & 0.056 & 0.086 & 0.625 \\
Farm size (hectare) & $0.094^{* *}$ & 0.047 & $0.024^{* *}$ & 0.011 & 4.099 \\
Share of area under F\&V (lagged) & -0.002 & 0.007 & -0.001 & 0.002 & 74.502 \\
Irrigation intensity F\&V (lagged) & $1.691^{* * *}$ & 0.549 & $0.425^{* * *}$ & 0.141 & 0.763 \\
Years of experience in F\&V production & -0.040 & 0.029 & -0.010 & 0.007 & 14.343 \\
Livestock ownership (dummy) & 0.198 & 0.580 & 0.053 & 0.167 & 0.116 \\
Specialization in vegetables (dummy) & 0.792 & 0.732 & 0.240 & 0.260 & 0.198 \\
Q-GAP certificate (dummy) & -0.488 & 0.458 & -0.134 & 0.140 & 0.707 \\
Exporter/supermarket supplier (dummy) & $2.698^{* * *}$ & 0.681 & $0.780^{* * *}$ & 0.125 & 0.311 \\
Public extension (dummy) & -0.558 & 0.430 & -0.119 & 0.082 & 0.215 \\
Membership in number of groups & $-0.799^{* * *}$ & 0.314 & $-0.201^{* *}$ & 0.087 & 1.058 \\
Mobile phone ownership (dummy) & 0.436 & 0.788 & 0.088 & 0.124 & 0.969 \\
Distance to provincial capital (km) & $-0.027 * * *$ & 0.010 & $-0.007^{* * *}$ & 0.003 & 42.110 \\
Training subjects attended including & $0.116^{* * *}$ & 0.032 & $0.029 * * *$ & 0.008 & 10.105 \\
those by the development program & $3.530^{* * *}$ & 1.074 & $0.876^{* * *}$ & 0.126 & 0.386 \\
QMS donor-managed (dummy) & $1.606^{* *}$ & 0.828 & $0.482^{* *}$ & 0.242 & 0.321 \\
QMS exporter-managed (dummy) & & & & &
\end{tabular}

Number of observations: 146

Wald chi2(23) $=82.28$

Prob $>$ chi2 $=0.0000$

Pseudo R2 $=0.5984$

Notes: Statistical significance at the $1 \%\left({ }^{* * *}\right), 5 \%\left({ }^{* *}\right)$ and $10 \%(*)$ levels. The marginal effects are calculated at the means of the variables. For dummy variables, the marginal effect is calculated for a discrete change from 0 to 1.

Source: Own data

Judging from the size of the marginal effects, we find that support from donors and exporters, education, the availability of family labor, household wealth, irrigation intensity and previous 
involvement in high-value supply chains are the most important determinants of GlobalGAP adoption.

In particular the support that farmers receive is crucial for standard adoption. A donormanaged QMS increases the probability to adopt by 88 percentage points while support and QMS management by an exporter raise the likelihood of GlobalGAP adoption by 48 percentage points. In the donor-managed groups almost all responsibility for GlobalGAP implementation was taken over by the donor. In the exporter-managed groups, the companies reduce the complexity of the GlobalGAP standard for farmers by offering advice and services, financial support and access to credits. In addition, they run the QMS for the farmers and monitor the farmers' compliance with GlobalGAP requirements. Hence, we can conclude that exporter and donor support is crucial for standard adoption and can help small-scale farmers with limited human, social and physical capital to adopt the standard.

Education is also a very important factor; a college degree in the household increases the probability of GlobalGAP adoption by 63 percentage points which confirms our hypothesis that less educated farmers have great difficulties in understanding and implementing the GlobalGAP requirements. Concerning the impact of age on the adoption decision, we can conclude that younger farmers are more likely to adopt GlobalGAP. They are usually more innovative, less risk averse and more flexible in adapting their farms to new requirements. The availability of family labor, female family labor in particular, is especially important. One additional female adult in the household increases the likelihood of adoption by 12 percentage points while one additional dependant and one additional household member participating in off-farm work decrease the probability to adopt by 17 and 22 percentage points, respectively. Women in the Thai horticultural sector usually take over the more labor intensive tasks such as harvesting and weeding (FAO and UNDP, 2003). GlobalGAP adoption is labor intensive and requires the implementation of Integrated Pest Management and record keeping, tasks that are frequently taken over by women in Thailand.

As expected, household wealth is another deciding factor. The ownership of one additional household asset increases the probability of GlobalGAP adoption by 10 percentage points and the ownership of one additional vehicle by 11 percentage points. Wealthier households have better access to liquidity and are better able to absorb risks, and may thus be more willing to make investments in GlobalGAP adoption. 
Furthermore, it is often argued that the high fixed costs share of the costs of compliance with GlobalGAP gives large-scale farmers a competitive edge over small-scale farmers. In our study, the effect of farm size is significant but small. A one hectare increase in farm size, which is large in this context since the average farm size in our sample is only 3.8 ha, only increases the likelihood of GlobalGAP adoption by two percentage points. In addition, the share of land cultivated with fruit and vegetables ${ }^{36}$ does not significantly influence GlobalGAP adoption. The intensity of irrigation, however, has a significantly positive effect indicating that more technologically advanced and more productive farmers are more likely to adopt GlobalGAP. A 10\% rise in the share of area under fruit and vegetables with sprinkler or drip irrigation leads to an increase in the likelihood of adoption by four percentage points. Finally, experience in high-value supply chains is important for standard adoption. Farmers who supplied an exporter or supermarket already before program participation have a 78 percentage points higher probability of adopting GlobalGAP.

\subsection{Conclusions and policy recommendations}

For the case of the Thai fruit and vegetable sector, we analyzed the costs and perceived benefits of GlobalGAP adoption for exporters and farmers, compared different institutional arrangements that can be formed under the GlobalGAP group certification option, namely a farmer-run, donor-run and an exporter-run QMS, and identified their effects on GlobalGAP adoption. Complying with the GlobalGAP standard is one of the major challenges for the Thai FFV export sector today to upgrade production. Exporters and producers alike often rely on technical and financial support by donors or other external agents during GlobalGAP implementation.

Exporters and farmers have different motivations to adopt GlobalGAP. Exporters state that their buyers have already requested the GlobalGAP certificate and that they aim to enhance their market access and increase buyers' trust. Farmers perceive quality increases, the enhancement of their families' and farm workers' health, as well as better marketing opportunities, more secure markets and higher prices as the major benefits of GlobalGAP adoption. Still, the costs of adoption are often assessed as higher than the benefits. While the non-recurrent costs are one of the main barriers to standard adoption, the recurrent costs can

\footnotetext{
${ }^{36}$ The share of land cultivated with fruit and vegetables refers to the area before participation in the development program.
} 
threaten the sustainability of adoption. In a case study of an exporter-managed asparagus farmer group, we found that the major share of both the initial investment costs and the recurrent costs was taken over by the company and that the costs the farmers had to incur were only about 5\%. Similarly, other exporters involved in the development program stated that they take over the major share of compliance costs for farmers because they feel that otherwise their suppliers are reluctant to adopt the standard.

The analysis of the determinants of GlobalGAP adoption at the farm level showed that support by donors and exporters in terms of trainings, financial and managerial support is critical to enable farmers to upgrade their production and implement the requirements of international food safety and quality standards. Furthermore, household and farm characteristics, such as education, the availability of family labor, access to irrigation, and previous experience in high-value supply chains are among the most important factors influencing standard adoption.

Based on these results, we suggest that increased support by donors and policy-makers is necessary in order to make higher food safety and quality standards accessible to a greater share of Thai farmers. ${ }^{37}$ Furthermore, although our analysis shows that ceteris paribus farmers in donor-managed groups are 40 percentage points more likely to adopt GlobalGAP than farmers in exporter-managed groups, public-private partnerships with exporters are likely to be the preferable way to enable small-scale farmers to participate in GlobalGAP certification schemes in the long run. The sustainability of standard adoption is expected to be much higher for farmers who are linked to exporters than for farmers who have adopted the standard without buyer support. Donors usually only offer support until the certificate has been obtained, while exporters have a continued interest in the GlobalGAP certificate and therefore offer long term support to farmers. Anecdotal evidence from our research region suggests that most farmers organized in donor-managed groups dropped out of certification after donor support was discontinued, while in many exporter-managed groups farmers were supported to renew their certificate. Further research based on repeated panel surveys is needed to look into these long-term effects of different institutional arrangements on standard adoption among small-scale farmers.

\footnotetext{
${ }^{37}$ We adopt a micro-economic perspective on financial support by donors for standard implementation. While it would go beyond the scope of this study, a macro-economic approach might be useful to gain further insights into this issue.
} 
Moreover, it is important to keep in mind that not only farmers, but also small and mediumscale exporters need assistance by donors to be able to adopt GlobalGAP. Given that small and medium-scale exporters frequently collaborate with small and medium-sized suppliers, their lack of compliance with standards is likely to have detrimental effects for producers down the value chain. 


\section{Innovative business models in the Thai horticultural sector: A panel data analysis of} the impacts of GlobalGAP certification ${ }^{38}$

\section{Abstract}

In recent years, compliance with international food safety and quality standards, such as GlobalGAP, has become increasingly important for farmers in developing countries supplying high-value markets. Adoption of the GlobalGAP standard is challenging and external support by exporters, donors or other support agencies is often necessary to enable small-scale farmers to adopt. While the factors influencing GlobalGAP adoption have been analyzed in several studies, the impacts of the standard remain less clear. This study for the first time presents a panel data analysis of the effects of GlobalGAP certification on net household income and producer prices, using a sample of 214 farmers in the Thai horticultural sector. We find that the impacts of GlobalGAP certification differ depending on whether farmers are organized in producer-managed or exporter-managed certification groups. In the producermanaged groups, GlobalGAP certification has led to significantly higher prices and to significantly higher net household incomes. In the exporter-managed certification groups, however, the effect of GlobalGAP certification on both prices and net household income is insignificant. Our results suggest that monetary benefits of GlobalGAP adoption do exist, but in cases where exporters finance GlobalGAP certification, those benefits are not passed on to farmers.

Keywords: business models, food safety standards, household income, producer prices, smallscale farmers, Thailand

\footnotetext{
${ }^{38}$ This chapter is forthcoming as a book chapter in a book entitled "Inclusive Agro-Enterprise Development" by FAO/Cornell University. The book is expected to be published in 2013 by World Scientific Publishing, Singapore.
} 


\subsection{Introduction}

In recent years, food safety and quality standards have become increasingly important in developing countries' value chains that target high-value export markets in Europe, North America and Japan, and increasingly also domestic supermarket channels (Boselie et al., 2003, Henson and Loader, 2001, Henson and Reardon, 2005). Some standards, like GlobalGAP, are discussed to have become quasi-mandatory to access these high-value markets, particularly in the case of horticultural crops. The implications for small-scale farmers are controversially debated among development experts. While evidence exists that the proliferation of standards has led to the exclusion of small-scale farmers (Dolan and Humphrey, 2000, Graffham et al., 2007b, Vagneron et al., 2009), there are several studies claiming that if smallholders are able to comply, standards can have positive impacts on farmers' livelihoods (Asfaw et al., 2009a, Asfaw et al., 2009b, Asfaw et al., 2010, Narrod et al., 2009). To successfully integrate small-scale farmers into high-value chains where standards are required, the development of new innovative business models, such as smallholder collective action, public-private partnerships and contract farming systems, is one of the key factors (Okello et al., 2011, Narrod et al., 2009, Henson et al., 2005). The present study focuses on a public-private partnership between Thai small and medium-scale export companies, the German International Cooperation (GIZ), Thai universities and local farmer groups. The main objective of the partnership was to increase GlobalGAP adoption among small-scale fruit and vegetable $(\mathrm{F} \& \mathrm{~V})$ producers. For the purpose of certification, farmers were organized in groups and a Quality Management System (QMS) was implemented at the group level. The different business models introduced by the project varied with respect to the institutional arrangement for the QMS, which was either run by exporters or by the farmers themselves with assistance by the development project.

The main aim of the study presented in this chapter is to evaluate the impacts of GlobalGAP certification on producer prices for fruit and vegetables (F\&V) and on farmers' net household income. While previous studies have looked at the aggregate effects of GlobalGAP adoption, we will take a more differentiated look and analyze whether the effects of GlobalGAP differ between certified farmers who are organized in producer-managed groups and those who are organized in exporter-managed groups. Our analysis is based on a panel data set collected in 2010 and 2011 among 218 farm households, of which 124 are program participants and 90 are non-participants. Of the interviewed participants, 72 farmers were successfully certified in 2010. Every household was interviewed twice over a one-year interval, which corresponds to 
the time periods before and after certification for the GlobalGAP adopters in our sample. To assess the impact of certification we apply the fixed effects approach, which controls for unobservable differences between treatment and control group.

Most existing studies on the impacts of GlobalGAP adoption have taken a qualitative approach and findings are still inconclusive (Ouma, 2010, Graffham et al., 2007b, Asfaw et al., 2009a, Asfaw et al., 2009b). Graffham et al. (2007) in a qualitative analysis of the impacts of GlobalGAP on small-scale farmers in Kenya state that the costs incurred by farmers for complying with GlobalGAP were not offset by higher prices, resulting in many smallholders dropping out of certification schemes. Similarly, Ouma (2010) concludes that out of twelve Kenyan exporters interviewed only two rewarded farmers for attaining GlobalGAP certification with higher price premiums. In contrast, Kariuki et al. (2012) using a sample of 249 Kenyan French bean suppliers show that GlobalGAP adoption leads to an average price increase of $9.5 \%$ and to a reduced price decline over the season. Nevertheless, they argue that the price increase is small compared to price premiums generated by supply contracts and direct procurement by exporters. Moreover, the price increase may be overestimated in their study because they are not controlling for potential selection bias among GlobalGAP adopters. It is also important to look at whether exporters benefit from GlobalGAP adoption because benefits they receive might be partly passed on to producers as incentives to comply with the standard. Ouma (2010) reports that all exporters interviewed for his study criticized that GlobalGAP certification has not led to higher prices although the implementation of the standard has increased costs considerably. However, price premiums are only one of the potential benefits of GlobalGAP adoption. Exporters and farmers might also gain from certification through enhanced market access that contributes to higher revenues. Henson et al. (2011) find that GlobalGAP adoption has a large significant impact on export sales of exporting enterprises in sub-Saharan Africa. At farm level, Asfaw et al. (2009a; 2009b; 2010), using a cross-sectional sample of small-scale Kenyan vegetable producers identified a positive impact of the standard on net income from export vegetable production, farm level productivity and farmers' health. However, if the analysis of income effects exclusively focuses on the income from export crop production, this may lead to biased results, as those farmers who successfully adopted the GlobalGAP standard may allocate resources away from other activities to increase their export crop production. To control for this effect, we will look at the impacts of GlobalGAP certification on farmers' total net household income. 
The chapter proceeds as follows. First, we will provide information on the background to the study, including an overview of business models that enable small-scale farmers to adopt GlobalGAP and a short description of the development project and the groups participating in the project. Next, we describe the survey design of our study. In section 3.3., we will present the econometric model used and introduce our hypotheses. Section 3.4. presents descriptive statistics and discusses our model results. Finally, we conclude with the main findings of the study presented in this chapter.

\subsection{Background and data}

\subsubsection{Inclusive business models and food safety standards}

External support by exporting enterprises and donors has been identified as one of the major factors influencing standard adoption by small-scale farmers in developing countries (Graffham et al., 2007b, Humphrey, 2008, Kleinwechter and Grethe, 2006, Kersting and Wollni, 2012, Henson et al., 2005). Certification against the GlobalGAP standard not only requires high investments in farm facilities and equipment, such as pesticide and fertilizer storages, toilets and protective clothing, but it also entails high information, administration and organizational costs. Smallholders in developing countries alone are not able to overcome these challenges because they are often disadvantaged in terms of access to credits and information and lack the human, physical and social capital to comply with the standard (Narrod et al., 2009). Different business models have been proposed, which successfully include small-scale farmers in GlobalGAP certification schemes. In most cases, such models focus on the GlobalGAP group certification option, Option $2^{39}$, which allows small-scale farmers to benefit from economies of scale and hence reduces the compliance costs for individual producers. Moreover, a group structure lowers transaction costs for exporters who support farmers in complying with the GlobalGAP standard. In particular, the costs of providing farmers with information, technical assistance and training are reduced (Will, 2010). There are two main group types under GlobalGAP group certification: producermanaged groups and exporter-managed groups (GTZ, 2010). In many cases NGOs, donors, and other support agencies offer support to GlobalGAP certification groups that include

\footnotetext{
${ }^{39}$ More recently, some smallholder farmer certification schemes have focused on GlobalGAP Option 1 (individual certification) as a multisite operation. These schemes are forms of vertical integration or contract farming where an exporter rents land from several small-scale farmers. The different production locations are managed and certified as one farm under Option 1.
} 
smallholders (Humphrey, 2008, Graffham et al., 2007b). In a previous study, Kersting and Wollni (2012) find that Thai small-scale F\&V farmers are significantly more likely to adopt the GlobalGAP standard if they are supported by donors or exporters. While there is growing evidence on how smallholders can best be included in GlobalGAP certification schemes, the benefits that farmers derive from being included are less clear. In particular, there is little evidence on the heterogeneous effects of standard compliance that may result from certification through different business models. We address this knowledge gap in our study by explicitly taking into account whether farmers are organized in producer-managed or exporter-managed certification groups. For the general case of farmer organizations, Markelova et al. (2009) show that downstream commercial agents in the value-chain, such as exporters, may support the organization of smallholders in order to maximize their own profits, which may result in conflicts over the distribution of value added between farmers and the supporting actor. However, they also argue that public sector facilitators or NGOs can sometimes be over-supportive potentially leading to unsustainable business models.

\subsubsection{Certification groups in the GlobalGAP Option 2 project}

The GlobalGAP Option 2 development project ${ }^{40}$ started in 2008 with the aim to increase the access of small commercial farmers to higher food safety, environmental and social standards. Besides directly supporting farmer groups and exporters in the GlobalGAP adoption process, the program trained farm advisors to provide consulting services to farmers and exporters and to disseminate information about GlobalGAP through seminars. At the start, the program included 355 producers, who were organized in four producer-managed groups and six exporter-managed groups for certification. In the course of the program, five groups and the majority of farmers dropped out of the project, so that in the end only 28 farmers were certified in three exporter-managed groups and 54 farmers were certified in three farmermanaged groups. In the exporter-managed groups, the majority of non-recurrent and recurrent costs associated with GlobalGAP compliance was paid for by the exporters. The exporters financed new farm facilities and farm equipment for their growers, such as pesticide storages, chemical disposal sites, plot markers, first aid kits, protective clothing and grading sheds. Moreover, they also covered the majority of recurrent costs, such as the costs for the external audit, pesticide residue, soil and water analyses and the management of the Quality

\footnotetext{
${ }^{40}$ The project described is a scaling-up project that was preceded by a pilot-project exploring the possibilities of GlobalGAP Option 2 certification for Thailand.
} 
Management System (QMS). The implementation of a QMS is a requirement of GlobalGAP group certification because in the external audit not each individual farmer, but only the square root of the group members is inspected which reduces the certification costs for the individual producer. Hence, the task of the QMS is to make sure that all group members comply with the GlobalGAP regulations and that those farmers sampled in the external audit are representative for the group as a whole. For exporters, the management of the QMS implies providing farm assistance and trainings to farmers, as well as monitoring their compliance on a weekly or monthly basis, and keeping records on the compliance of all group members.

In the producer-managed groups, the lack of support by downstream actors and the lack of secure market linkages was one of the main difficulties faced by the project. Farmers organized in these groups had to cover the major share of investment costs by themselves while the costs of the external audit and laboratory analyses were covered by the program. The three producer-managed groups certified differ with respect to their level of market integration. The first group is led by a collector with very strong connections to a variety of exporters, supermarkets, restaurants and wholesalers. The second group is equally well integrated, selling directly to a variety of domestic supermarkets. The third and largest group, however, lacked linkages to high-value markets, and prior to certification members sold their produce separately, usually to middlemen at the farm gate. With GlobalGAP certification in reach, the development program accomplished to link the group to high-value markets as well. Farmers were contracted by a packaging house that collected, washed and packed the produce. The major share was sold as fresh produce to a domestic supermarket, a smaller share was frozen and then exported, and a very small part was sold as dried produce to various channels. At the packaging house, a team of farm advisors was employed that was paid by the development program. They took over the main responsibilities in the management of the QMS and also provided farm assistance to growers. 


\subsubsection{Sampling and survey design}

In order to assess the impacts of GlobalGAP certification, we carried out a panel data survey of fruit and vegetable farmers in Northern, Eastern, Southern and Central Thailand ${ }^{41}$. The first round of data collection took place between March and May 2010 and the second round was conducted between March and May 2011. In the surveys, covering a one-year recall period from March to the end of February, we collected quantitative and qualitative information on socio-economic and farm characteristics, agricultural production and input use, marketing decisions, compliance with standards, group membership and training participation. In the following analysis, the first survey interval will be referred to as the year 2009 and the second survey interval as the year 2010.

For the sampling frame, we divided the relevant population into four strata: (1) program participants who are likely to adopt GlobalGAP (N=118), (2) program participants who are not likely to achieve GlobalGAP certification ( $\mathrm{N}=237$ ), (3) non-participants in program regions ( $\mathrm{N}=$ approx. 710 ), and (4) non-participants outside program regions ( $\mathrm{N}=$ approx. 415). Sampling of program participants was based on a complete list of participants provided by the development program including complete names of participants, location and adoption status $^{42}$. To obtain a sufficiently large sample of adopters we selected all households for interviews that were categorized as prospective adopters at the time of the first survey. Of the $118^{43}$ households listed as prospective adopters, 97 were available for interviews in the first survey round. For the second strata, we randomly selected 49 households from the list to be included in the sample. Non-participants within and outside program regions were sampled through random walks, provided that they produce at least one of the products that were considered for GlobalGAP certification ${ }^{44}$. Our internal control group, consisting of nonparticipant households within program regions, was sampled in villages where the development program was active. Hence, this group was exposed to the activities of the

\footnotetext{
${ }^{41}$ Interviews were carried out in the following provinces: Kanchanaburi, Ayuttayah, Nakhon Pathom, Ratchaburi, Samut Sakhorn, Saraburi (Central Thailand), Sa Kaew, Chachoengsao, Prachin Buri (Eastern Thailand), Chumporn (Southern Thailand), Phayao, Phichit, Chiang Mai (Northern Thailand).

${ }^{42}$ During the preparation phase of the first survey in the beginning of 2010, 118 households were listed as prospective adopters by the development project. At this stage, farmers were classified as likely adopters if they were in the adoption process and expected to achieve certification by mid of 2010, i.e. within the duration of the development project. In addition, six households are included in the category of prospective adopters who were certified before the survey and took part in the development project because they needed assistance to become re-certified.

${ }^{43}$ Only 82 of the households initially classified as prospective adopters became certified.

${ }^{44}$ The following products were considered for GlobalGAP certification: lychee, durian, mangosteen, papaya, dragon fruit, cantaloupe, mango, asparagus, green okra, spring onion, yard long bean, different kinds of herbs and green leafy vegetables.
} 
development program and is potentially affected by spillover effects. Therefore, to have a more robust control group, we additionally sampled non-participants outside program regions. Ten districts were identified as external control areas through consultations with agricultural professors in Thailand and stakeholders of the development program. The selected districts have similar agro-ecological conditions to districts within program regions and are known as major production areas of the crops considered for GlobalGAP certification by program participants. In total, 287 farmers were interviewed in 2010 of which 146 are program participants, 84 are non-participants within program regions and 57 are non-participants outside program regions.

To some extent sample attrition occurred in 2011, so that we were able to interview 218 of the 287 households a second time. Of the 218 households interviewed in the second survey, 124 are program participants, 57 are non-participants in program regions and 37 are nonparticipants outside program regions. There are different reasons for why some farmers were not included in the second survey. First, for some of the households the contact information given was incorrect or they had moved away, and second, some households were not available for interviews. In the following analysis, we will only use 214 of the 218 households because four households stopped growing fruit and vegetables completely.

\subsection{Econometric analysis}

The main objective of our study is to analyze the impact of GlobalGAP certification on (1) producer prices for $\mathrm{F} \& \mathrm{~V}$ and on (2) net household income. In addition to average treatment effects, we are interested in whether the effect of GlobalGAP depends on the type of business model used, namely producer-managed groups or exporter-managed groups for certification. For this purpose, we formulate different specifications of a panel data model estimating mean F\&V producer prices and net household income. In a first specification for both income and price analysis, we include a dummy variable that is equal to one if a farmer is GlobalGAP certified in $2010^{45}$, zero otherwise. In a second specification, we include two dummy variables, the first one being equal to one if a farmer is certified in an exporter-managed group

\footnotetext{
${ }^{45}$ For the purpose of our estimation, we define the six farmers who were certified in both survey periods as nonadopters in 2009 because we expect that not only initial certification, but also the renewal of the certificate has a positive influence on prices and net household income. If they are classified as adopters in both time periods, they are counted as non-certified farmers in the fixed effects model because there is no change in certification status between the years.
} 
and the second one being equal to one if a farmer is certified in a producer-managed group. Furthermore, since scale economies are likely to be important in the adoption of the GlobalGAP standard, the income effect of certification may vary depending on farm size. We therefore include variables on the size of the area that is certified, the certified area in producer-managed and in exporter-managed groups in additional specifications of our model. The adoption of the GlobalGAP standard is likely to be correlated with unobservable characteristics that also influence producer prices and net household income ${ }^{46}$. In particular, farmers who are more motivated and progressive are more likely to achieve certification with GlobalGAP, which is a complex and knowledge-intensive standard. These personal characteristics and attitudes, however, are also likely to positively affect the ability of the household to obtain higher prices and incomes. As we cannot control for these unobserved variables, a simple ex-post comparison of prices and incomes between adopters and nonadopters would most likely lead to biased estimates. Given that we have data before and after certification for both adopters and non-adopters, we use a fixed effects model to control for time-invariant unobserved heterogeneity across households. The fixed effects model is specified as follows:

$y_{i t}=\boldsymbol{x}_{i t} \boldsymbol{\beta}+v_{i t}$,

where $t$ denotes the time period, $i$ indicates the individual, and $\boldsymbol{x}_{i t}$ is a vector of observable variables that change across both time $t$ and individuals $i$, across $i$, but not $t$ and variables that change over time but not across individuals. The error term $v_{i t}$ is a composite error term $\left(v_{i t} \equiv c_{i}+u_{i t}\right)$ that consists of the unobserved effect $c_{i}$, which captures features of individuals that do not change over time, such as ability and motivation, and $u_{i t}$ which is the idiosyncratic error that changes over $\mathrm{t}$ as well as across $i$. The unobserved effect $c_{i}$, is allowed to be correlated with the explanatory variables ${ }^{47}$. Hence, once we include time-variant explanatory variables along with time-invariant unobserved effects in our model, the value of the time-variant variables in previous years has no effect on the outcome variable in the current year. The fixed effects estimator uses the variation over time within each crosssectional observation and is based on time-demeaned data. Explanatory variables that are constant over time are removed by the time-demeaning and hence cannot be estimated with the fixed effects approach (Wooldridge, 2010).

\footnotetext{
${ }^{46}$ This may also refer to several other variables included on the right-hand-side of our model.

${ }^{47}$ Here we assume that the managerial ability and other unobserved effects are roughly constant over time. The shortcoming of our model is that we cannot control for unobserved effects that are time-variant and correlated with the outcome variable.
} 
We will use two weights in the estimation procedure, sampling weights ${ }^{48}$ to account for the overrepresentation of development program participants in our sample and inverse probability weights to correct for sample attrition that is based on observable characteristics. To test whether sample attrition is random or not, we carried out attrition probit tests (Fitzgerald et al., 1998) and pooled tests (Becketti et al., 1988). The results of both tests show that attrition is nonrandom in our sample. More specifically, we find that participation in the development project, age of the household head and location of the household significantly influence attrition. Hence, we calculate inverse probability weights which give more weight to households that are similar to households who are likely to attrit than to households that are more comparable to non-attritors. Weights are calculated as follows. First, the predicted probabilities of the unrestricted retention probit model are estimated using explanatory variables that are observable for both attritor and non-attritor households, and that might be correlated with the likelihood of attrition. Then the model is re-estimated as a restricted model including only those explanatory variables that are not significantly associated with attrition. The inverse probability weights are then calculated as the ratio of the restricted to the unrestricted probabilities (Baulch and Quisumbing, 2011) ${ }^{49 .}$

\subsubsection{Impact of GlobalGAP certification on producer prices}

To estimate the impact of GlobalGAP certification on producer prices we estimate a model with the log transformed mean weighted price per $\mathrm{kg}$ of $\mathrm{F} \& \mathrm{~V}^{50}$ as a dependent variable. To measure the effects of GlobalGAP certification, we include a dummy variable measuring GlobalGAP certification in 2010 in a first specification and two dummies for certification in exporter-managed groups and producer-managed groups in a second specification. As additional explanatory variables, we include the total quantity of F\&V sold, the share of F\&V sold to high-value markets, the share of F\&V sold that is graded, three variables related to contracts and resource provision by buyers, a range of variables capturing the share of

\footnotetext{
${ }^{48}$ Sampling weights are calculated as the inverse of the sampling fraction, i.e. the total number of households in each population divided by the number of samples drawn from that population.

${ }^{49}$ Results of the attrition tests and the calculation of inverse probability weights are provided by the authors on request.

${ }^{50}$ For each farmer, the mean weighted price per $\mathrm{kg}$ of products $n=1 \ldots \mathrm{N}$ in grades $i=1 \ldots$ In is calculated as follows: $\overline{\mathrm{p}}=\sum_{n=1}^{N} \sum_{i n=1}^{I n}\left(\frac{q_{n i n}}{Q}\right) * p_{\text {nin }}$, where $\mathrm{Q}=$ total quantity of $\mathrm{F} \& \mathrm{~V}$ sold, $q_{n i n}=$ quantity of product $n$ in grade $i, p_{i n i}=$ price of product $n$ in grade $i$.
} 
different crops in the total quantity of $\mathrm{F} \& \mathrm{~V}$ sold $^{51}$, and a year dummy variable measuring time fixed effects.

Regarding our first research question, i.e., the impact of GlobalGAP certification on producer prices for fruit and vegetables, we hypothesize that there are significant price premiums associated with GlobalGAP certified produce. The GlobalGAP standard adds value to the product by assuring buyers that desired but unobservable product attributes, such as adherence to maximum residue levels or the use of safe irrigation water, are fulfilled. In the absence of a certificate, product attributes unobservable to the buyer do not entail price premiums, unless there are reputation effects that enable the producer to credibly assure the customer that the product possesses the desired characteristics (Fafchamps et al., 2008). Our second hypothesis, which will be tested in a second model, refers to the heterogeneous impact of GlobalGAP certification on prices, depending on the type of business model used. We expect that certified farmers in producer-managed groups benefit from higher price premiums as compared to famers in exporter-managed groups. While in the producer-managed groups, the costs of compliance were covered by adopters themselves and the development program, in the exporter-managed groups both non-recurrent and recurrent costs for GlobalGAP adoption were mainly covered by the exporters. We therefore expect that exporters implicitly deduct the costs incurred for GlobalGAP certification from producer prices, hence resulting in significantly reduced price premiums. On the other hand, exporters may decide to pay price premiums to reward farmers for complying with the GlobalGAP standard. Exporters have undertaken large transaction-specific investments to support farmers in the GlobalGAP adoption process, leaving them at risk of farmers' opportunistic behavior. Therefore, they may choose to set prices high enough to discourage side-selling of farmers at times when market prices are higher than the prices agreed upon in the contract (Minten et al., 2009).

With respect to the other explanatory variables included in the models, we expect a positive influence of the total quantity sold on prices because farmers selling larger amounts are expected to have a higher bargaining power. In addition, the per unit costs of price and contract negotiations for buyers are lower for larger than for smaller transactions, which may be reflected in higher prices paid to larger farmers. In line with this, Mausch et al. (2009) find that small-scale GlobalGAP certified farmers receive 16\% lower prices than large-scale certified farmers, which they attribute to lower bargaining power and higher monitoring and

\footnotetext{
${ }^{51}$ We use the share of different crops in the total quantity of F\&V sold instead of crop dummies because the shares vary across the two years, whereas crop dummies are largely constant over time in our sample.
} 
enforcement costs associated with smaller farmers. The variable "share of F\&V sold to highvalue markets” includes the share sold to exporters and supermarkets either directly or through specialized suppliers. We expect a positive influence of the variable since high-value markets demand the consistent delivery of high quality products, which is usually rewarded by price premiums. The share of $F \& V$ sold that is graded is also expected to have a positive influence on prices. Through grading, observable variation in product quality is accounted for by price differentials. Furthermore, we hypothesize that production under contract can have a significant influence on product prices. For the analysis, we classify contracts in two main categories: market-specification ${ }^{52}$ contracts and production-management ${ }^{53}$ contracts (Minot, 1986). Market-specification contracts are negotiated prior to the harvest and usually include details on prices, quality and timing of delivery. Market-specification contracts might have a positive or negative influence on prices. On the one hand, their impact might be negative if small-scale farmers are risk averse and therefore willing to accept guaranteed future prices which are below the expected market price (Key and Runsten, 1999). On the other hand, marketing contracts might include a premium for higher quality and firms might set prices that are high enough to prevent contracted producers from side-selling to other buyers at times of high market demand (Minten et al., 2009). Production-management contracts, in addition to the above mentioned specifications, define a particular production method or input regime to be followed by the farmer. Frequently, buyers provide farmers with market information and technical assistance to overcome missing markets for information (Minot, 1986), which is especially relevant in the context of supplying high-value export markets that demand stringent food safety and quality standards (Key and Runsten, 1999). The impact of production-management contracts on producer prices is also not clear a priori. On the one hand, the impact may be positive if farmers' efforts to follow strict guidelines laid out in the contract are rewarded by higher prices. On the other hand, buyers might implicitly charge farmers for the services provided resulting in lower producer prices (Minot, 1986). Finally, we hypothesize that input and credit provision by buyers has a negative influence on prices.

\footnotetext{
${ }^{52}$ We classify a contract as a market-specification contract if the farmer has a written or oral agreement with the buyer, and at least one of the following is specified in the contract: pricing of the product, product grades, timing of delivery, amount of delivery, but no requirements are specified in terms of production methods or input use. Farm assistance is also not provided.

${ }^{53}$ We classify a contract as a production-management contract if the farmer has a written or oral agreement with the buyer, and at least one of the following is specified in the contract: use of only those crop protection products that are approved by the buyer, record keeping requirements, production according to the regulations of the QGAP standard. The contract is also classified as a production-management contract if the buyer provides farm assistance. Production-management contracts can also include details described above as classifying marketspecification contracts.
} 
Credits and inputs are often provided to farmers at subsidized rates and the costs of these subsidies are then subtracted from product prices (Minot, 1986).

The GlobalGAP standard, however, is not only expected to influence producer prices directly, but may also influence several of the marketing-related factors that are included as explanatory variables in our models, and thus have an indirect effect on producer prices. In particular, GlobalGAP certification may be positively associated with larger shares sold to high-value markets and larger shares sold as graded produce. Certification can serve as a signal to buyers that producers adhered to the strict food safety and quality rules of the standard thus improving their access to high-value markets. Since in high-value markets product grades for observable attributes such as size, color and variety are used more frequently (Jaffee et al., 2011), greater participation in such markets will also lead to an increase in the share of produce that is graded. Furthermore, GlobalGAP certification is often associated with tighter buyer-producer relations and increased resource provision by buyers. As a result, producers and buyers may engage in contractual agreements that also influence the prices received by producers. To account for these potential correlations between GlobalGAP certification and other explanatory variables, we show two specifications of the panel data model on mean $\mathrm{F} \& \mathrm{~V}$ producer prices. The first specification excludes the marketing-related variables, such as participation in high-value markets, grading, contracts and resource provision by buyers, to capture the full effect of GlobalGAP certification on producer prices. The second specification controls for all potential factors attempting to disentangle the effect of different marketing strategies.

\subsubsection{Impact of GlobalGAP on net household income}

Our second research objective relates to the impact of GlobalGAP certification on net household income. We calculate net household income (NHI) as follows ${ }^{54}$ :

$\mathrm{NHI}=(\mathrm{TFR}-\mathrm{VC})+\mathrm{OFE}+\mathrm{NSE}$,

where TFR = total farm revenue, $\mathrm{VC}=$ variable costs, OFE $=$ wages and salaries from offfarm employment, and NSE = net returns from self-employment.

\footnotetext{
${ }^{54}$ Unfortunately, we do not have information on the amount of remittances received by households and therefore cannot account for their value in the calculation of net household income.
} 
Different model specifications are formulated to estimate the average and subgroup-specific mean impact as well as the per hectare effect of GlobalGAP certification on farmers' net household income. In a first specification, we include a dummy variable that is equal to one if a farmer is certified in 2010, zero otherwise, which measures the average effect of certification. In a second specification, we include two dummies for certification in exportermanaged groups and producer-managed groups to look at heterogeneous treatment effects between subgroups of adopters. Furthermore, to measure the per hectare effect of GlobalGAP certification, we include the size of the GlobalGAP certified area in ha, the certified area in producer-managed and exporter-managed groups as explanatory variables in further specifications.

As additional control variables, we include the cultivated area with F\&V measured in ha, the cultivated area with other crops, the number of household members working off-farm, the total number of household members as a proxy for access to family labor, a range of variables capturing the share of the area cultivated with different products separately for fruit and vegetables and for other crops, and a dummy variable which is equal to one if the household has experienced a drought. One of the project regions was affected by a severe drought in 2010 which has led to large harvest losses. We do not include a year dummy in the model because it is highly correlated with the dummy for drought in 2010.

Since GlobalGAP certified farmers are likely to increase their share of F\&V sold to highvalue markets and to receive higher product prices, we also expect a positive effect of certification on net household income. On the other hand, premium prices for GlobalGAP adoption do not necessarily imply higher net incomes because the GlobalGAP standard is associated with significant compliance and adjustment costs that might diminish the positive income effect generated by higher prices. While the recurrent costs of compliance, like certification fees, soil analyses and health checks, did not have to be paid by farmers in our sample, because during the first year of certification they were covered by the development program and by exporters, adjustment costs may still be substantial. Certified farmers may for example have to incur higher variable costs that are indirectly related to standard adoption, such as higher labor costs due to labor-intensive record keeping and weeding practices that are required under the GlobalGAP standard. Similarly, GlobalGAP regulations stipulate that only those chemicals can be used that are registered in the country of use for the target crop (FoodPLUS, 2011b), which are often more expensive, and thus may result in higher pesticide costs (Asfaw et al., 2009a). These effects are also likely to be heterogeneous between the 
different types of certification groups, given that farmers in producer-managed and exportermanaged groups received different levels of support and financial assistance. As argued in the previous section, farmers in exporter-managed groups are likely to receive lower price premiums, because exporters made substantial investments in farm-level upgrading. This may then also result in lower overall impacts of the GlobalGAP standard on the net household income of adopters in exporter-managed groups compared to adopters in producer-managed groups.

\subsection{Results and discussion}

\subsubsection{Descriptive statistics}

\subsubsection{Marketing of F\&V}

In the following section, we descriptively analyze changes in $\mathrm{F} \& \mathrm{~V}$ product prices, market access and contracts following GlobalGAP certification. Table 8 shows an overview of the marketing performance of farmers in our sample. We first compare whether the marketing performance differed between certified and non-certified producers before GlobalGAP certification, and then look at the changes from 2009 (before certification) to 2010 (after certification). In addition, we compare the marketing performance between certified farmers organized in producer-managed certification groups and those organized in exporter-managed certification groups.

Comparing prices and marketing performance between certified and non-certified producers in 2009, we find that mean prices were not significantly different between the two groups before certification. However, certified farmers sold a significantly higher share of their produce to high-value markets already in 2009 than non-certified farmers. Moreover, we find significant differences between the two groups with respect to the types of contractual arrangements used and the quantity of fruit and vegetables sold. Compared to non-certified producers, certified farmers sold less fruit and vegetables and were less often engaged in market-specification contracts.

Next, we compare changes from 2009 to 2010 between certified and non-certified producers. We find that certified producers increased their mean price by 0.48 USD on the average, whereas non-certified farmers only experienced an average increase of 0.07 USD. The 
difference is statistically significant suggesting that there are considerable price premiums associated with the GlobalGAP standard. Furthermore, certified producers already delivering higher shares of their produce to high-value markets before certification were able to further increase their access to these markets. While in the case of certified farmers the share of $F \& V$ sold to high-value markets increased by 36\% between 2009 and 2010, it stayed almost constant in the case of non-certified farmers. Finally, certified farmers were able to expand the share of $F \& V$ sold under production-management contracts by $32 \%$. This change is significantly different from the change experienced by non-certified farmers, whose contractual arrangements remained largely constant over the study period. This finding confirms that GlobalGAP adoption often goes hand in hand with more intensive farm assistance and closer monitoring by buyers, for which production management contracts can provide a safeguard.

Comparing the two groups of certified farmers, we find evidence for our hypothesis that there are heterogeneous effects of the GlobalGAP standard depending on whether certification is buyer-driven or producer-driven. We find that before GlobalGAP certification in 2009, farmers in producer-managed groups were less integrated into high-value supply chains than those organized in exporter-managed groups. They sold a significantly lower share of their produce to high-value markets, a lower share under production-management contracts, and less often received inputs or credits from buyers as compared to farmers in exporter-managed groups.

Following certification, however, farmers in producer-managed groups were able to catch-up. The results for price changes following certification are particularly striking. For certified farmers in producer-managed groups, prices have nearly doubled, from 0.86 USD in 2009 to 1.55 USD in 2010. In contrast, the prices in exporter-managed groups have remained stable. Similarly, the share sold to high-value markets and the share sold under productionmanagement contracts has increased significantly for members of the producer-managed certification groups, while there has been almost no change for farmers in exporter-managed groups. This can be attributed to the fact that farmers organized and certified in exportermanaged groups had the contracting exporter as their main buyer before and after certification, whereas farmers in producer-managed groups gained access to new markets as a result of certification. 
Table 8: Differences in marketing of F\&V: prices, quantities, marketing channels and contracts

\begin{tabular}{|c|c|c|c|c|c|c|c|c|}
\hline & \multicolumn{2}{|c|}{ Year 2009} & \multicolumn{2}{|c|}{$\Delta$ 2010-2009 } & \multicolumn{2}{|c|}{ Year 2009} & \multicolumn{2}{|c|}{$\Delta$ 2010-2009 } \\
\hline & $\begin{array}{l}\text { Certified } \\
\text { farmers } \\
(\mathrm{N}=72)\end{array}$ & $\begin{array}{c}\text { Non- } \\
\text { certified } \\
\text { farmers } \\
(\mathrm{N}=131)\end{array}$ & $\begin{array}{l}\text { Certified } \\
\text { farmers } \\
(\mathrm{N}=72)\end{array}$ & $\begin{array}{l}\text { Non- } \\
\text { certified } \\
\text { farmers } \\
(\mathrm{N}=131)\end{array}$ & $\begin{array}{l}\text { Producer- } \\
\text { managed } \\
\text { groups } \\
(\mathrm{N}=49)\end{array}$ & $\begin{array}{l}\text { Exporter- } \\
\text { managed } \\
\text { groups } \\
(\mathrm{N}=23)\end{array}$ & $\begin{array}{l}\text { Producer- } \\
\text { managed } \\
\text { groups } \\
(\mathrm{N}=49)\end{array}$ & $\begin{array}{l}\text { Exporter- } \\
\text { managed } \\
\text { groups } \\
(\mathrm{N}=23)\end{array}$ \\
\hline $\begin{array}{l}\text { Mean F\&V price } \\
\text { (USD) }\end{array}$ & $\begin{array}{c}0.81 \\
(0.41)\end{array}$ & $\begin{array}{c}0.72 \\
(0.48)\end{array}$ & $\begin{array}{c}0.48 * * * \\
(0.63)\end{array}$ & $\begin{array}{c}0.07 \\
(0.61)\end{array}$ & $\begin{array}{c}0.86 \\
(0.47)\end{array}$ & $\begin{array}{c}0.71 \\
(0.18)\end{array}$ & $\begin{array}{c}0.69 * * * \\
(0.62)\end{array}$ & $\begin{array}{c}0.03 \\
(0.34)\end{array}$ \\
\hline $\begin{array}{l}\text { Share sold to high- } \\
\text { value markets }\end{array}$ & $\begin{array}{c}0.42^{* * *} \\
(0.46)\end{array}$ & $\begin{array}{c}0.26 \\
(0.42)\end{array}$ & $\begin{array}{c}0.36^{* * *} \\
(0.55)\end{array}$ & $\begin{array}{c}0.04 \\
(0.44)\end{array}$ & $\begin{array}{c}0.25 * * * \\
(0.43)\end{array}$ & $\begin{array}{c}0.79 \\
(0.27)\end{array}$ & $\begin{array}{c}0.55^{* * * *} \\
(0.50)\end{array}$ & $\begin{array}{l}-0.04 \\
(0.41)\end{array}$ \\
\hline $\begin{array}{l}\text { Share sold that is } \\
\text { graded }\end{array}$ & $\begin{array}{c}0.76 \\
(0.40)\end{array}$ & $\begin{array}{c}0.71 \\
(0.43)\end{array}$ & $\begin{array}{c}0.08 \\
(0.48)\end{array}$ & $\begin{array}{c}0.02 \\
(0.49)\end{array}$ & $\begin{array}{c}0.78 \\
(0.42)\end{array}$ & $\begin{array}{c}0.72 \\
(0.35)\end{array}$ & $\begin{array}{c}0.12 \\
(0.43)\end{array}$ & $\begin{array}{l}-0.003 \\
(0.56)\end{array}$ \\
\hline $\begin{array}{l}\text { Share sold under a } \\
\text { market-specification } \\
\text { contract }\end{array}$ & $\begin{array}{c}0.02 * * * \\
(0.12)\end{array}$ & $\begin{array}{c}0.27 \\
(0.43)\end{array}$ & $\begin{array}{c}0.02 \\
(0.19)\end{array}$ & $\begin{array}{l}-0.05 \\
(0.57)\end{array}$ & $\begin{array}{c}0.00 \\
(0.01)\end{array}$ & $\begin{array}{c}0.04 \\
(0.21)\end{array}$ & $\begin{array}{c}0.03 \\
(0.15)\end{array}$ & $\begin{array}{l}0.003 \\
(0.27)\end{array}$ \\
\hline $\begin{array}{l}\text { Share sold under a } \\
\text { production- } \\
\text { management } \\
\text { contract }\end{array}$ & $\begin{array}{c}0.40 \\
(0.46)\end{array}$ & $\begin{array}{c}0.30 \\
(0.44)\end{array}$ & $\begin{array}{c}0.32 * * * \\
(0.56)\end{array}$ & $\begin{array}{c}0.02 \\
(0.47)\end{array}$ & $\begin{array}{c}0.27 * * * \\
(0.44)\end{array}$ & $\begin{array}{c}0.66 \\
(0.37)\end{array}$ & $\begin{array}{c}0.45^{* * *} \\
(0.54)\end{array}$ & $\begin{array}{c}0.06 \\
(0.50)\end{array}$ \\
\hline $\begin{array}{l}\text { Share sold for which } \\
\text { inputs and/or credits } \\
\text { are provided }\end{array}$ & $\begin{array}{c}0.32 \\
(0.44)\end{array}$ & $\begin{array}{l}0.26 \\
(0.42)\end{array}$ & $\begin{array}{l}-0.003 \\
(0.40)\end{array}$ & $\begin{array}{l}-0.05 \\
(0.39)\end{array}$ & $\begin{array}{c}0.16 * * * \\
(0.36)\end{array}$ & $\begin{array}{c}0.67 \\
(0.40)\end{array}$ & $\begin{array}{c}0.01 \\
(0.37)\end{array}$ & $\begin{array}{l}-0.02 \\
(0.46)\end{array}$ \\
\hline $\begin{array}{l}\text { Total quantity of } \\
\text { F\&V sold (kg) }\end{array}$ & $\begin{array}{c}13,496 * * * \\
(24,383)\end{array}$ & $\begin{array}{c}26,777 \\
(43,179)\end{array}$ & $\begin{array}{c}1069 \\
(13,207)\end{array}$ & $\begin{array}{c}2523 \\
(52,006)\end{array}$ & $\begin{array}{c}13554 \\
(28,892)\end{array}$ & $\begin{array}{l}13,373 \\
(9870)\end{array}$ & $\begin{array}{c}61 \\
(13,389)\end{array}$ & $\begin{array}{c}3217 \\
(12,832)\end{array}$ \\
\hline
\end{tabular}

Notes: Standard deviations are shown in parentheses. *, **, *** imply the mean value in 2009 / the change from 2009 to 2010 is statistically different between certified and non-certified farmers/farmers certified in producermanaged groups and famers certified in exporter-managed groups at the $10 \%, 5 \%$ and $1 \%$ level, respectively.

Source: Own data

\subsubsection{Costs, revenues and household income}

Table 9 shows differences in per hectare costs and revenue of $F \& V$ production for certified and non-certified producers in 2009, i.e., before certification, and compares changes from 2009 to 2010. In 2009, there are no significant differences with respect to the gross revenue per hectare, total variable costs per hectare, and net revenue per hectare between certified and non-certified farmers. Comparing changes from 2009 to 2010, we find that notwithstanding the high price increase among certified farmers following certification, their gross revenue per hectare did not increase over the same period. This can be explained by an average decline in per hectare yields of $21 \%$ for certified famers. Regarding production costs, certified farmers experienced an increase in seed costs and other variable costs per hectare that is significantly different from the change among non-certified farmers. The category 'other variable costs' includes amongst others the costs for irrigation, fuel, tractor rental, electricity and packaging material. Yet, the change in total variable costs is not statistically different between the two groups. 
Next, we compare differences and changes in costs and revenues of certified farmers in producer-managed and exporter-managed groups. We find that before certification in 2009, farmers in producer-managed groups have both significantly lower gross revenues per hectare as well as significantly lower total variable costs per hectare than farmers in exportermanaged groups. The large differences in gross revenues can mainly be explained by yield differences since the yield of members in producer-managed groups is significantly lower than that of farmers in exporter-managed groups. Moreover, yield changes from 2009 to 2010 are significantly different between the two groups. While the average yield per hectare of certified farmers in producer-managed groups decreased by more than $40 \%{ }^{55}$, certified farmers in exporter-managed groups experienced a slight increase in per hectare yield. Despite the considerable decline in yields, the gross revenues of certified farmers in producermanaged groups decreased only slightly and the change is not significantly different from that of farmers certified in exporter-managed groups. This can be attributed to the significantly higher prices obtained by farmers certified in producer-managed groups after certification that helped to compensate the negative yield effects.

\footnotetext{
55 This decrease was largely due to unfavorable climatic conditions, which we control for in the econometric analysis.
} 
Table 9: Costs and revenue of $F \& V$ production per ha

\begin{tabular}{|c|c|c|c|c|c|c|c|c|}
\hline & \multicolumn{2}{|c|}{ Year 2009} & \multicolumn{2}{|c|}{$\Delta 2010-2009$} & \multicolumn{2}{|c|}{ Year 2009} & \multicolumn{2}{|c|}{$\Delta$ 2010-2009 } \\
\hline & $\begin{array}{l}\text { Certified } \\
\text { farmers } \\
(\mathrm{N}=72)\end{array}$ & $\begin{array}{c}\text { Non- } \\
\text { certified } \\
\text { farmers } \\
(\mathrm{N}=142)\end{array}$ & $\begin{array}{l}\text { Certified } \\
\text { farmers } \\
(\mathrm{N}=72)\end{array}$ & $\begin{array}{c}\text { Non- } \\
\text { certified } \\
\text { farmers } \\
(\mathrm{N}=142)\end{array}$ & $\begin{array}{c}\text { Producer- } \\
\text { managed } \\
(\mathrm{N}=49)\end{array}$ & $\begin{array}{c}\text { Exporter- } \\
\text { managed } \\
(\mathrm{N}=23)\end{array}$ & $\begin{array}{l}\text { Producer- } \\
\text { managed } \\
(\mathrm{N}=49)\end{array}$ & $\begin{array}{c}\text { Exporter- } \\
\text { managed } \\
(\mathrm{N}=23)\end{array}$ \\
\hline Gross revenue & 6037 & 6241 & -14 & -251 & $5368 *$ & 7462 & -17 & -8 \\
\hline (USD/ha) & (4940) & (7763) & (5110) & $(10,799)$ & (4314) & (5918) & (4906) & (5635) \\
\hline Yield in kg per ha & $\begin{array}{c}7761 \\
(5968)\end{array}$ & $\begin{array}{c}10,744 \\
(17,321)\end{array}$ & $\begin{array}{l}-1658 \\
(6524)\end{array}$ & $\begin{array}{c}-653 \\
(21,019)\end{array}$ & $\begin{array}{l}6734^{* *} \\
(5201)\end{array}$ & $\begin{array}{c}9947 \\
(6971)\end{array}$ & $\begin{array}{l}-2566^{*} \\
(6545)\end{array}$ & $\begin{array}{c}278 \\
(6177)\end{array}$ \\
\hline $\begin{array}{l}\text { Seed costs } \\
\text { (USD/ha) }\end{array}$ & $\begin{array}{c}77 \\
(177)\end{array}$ & $\begin{array}{c}68 \\
(279)\end{array}$ & $\begin{array}{l}124 * * \\
(588)\end{array}$ & $\begin{array}{c}8 \\
(294)\end{array}$ & $\begin{array}{c}59 \\
(146)\end{array}$ & $\begin{array}{l}115 \\
(228)\end{array}$ & $\begin{array}{l}42 * \\
(212)\end{array}$ & $\begin{array}{l}297 \\
(985)\end{array}$ \\
\hline $\begin{array}{l}\text { Pesticide costs } \\
\text { including } \\
\text { biopesticides } \\
\text { (USD/ha) }\end{array}$ & $\begin{array}{c}140 \\
(321)\end{array}$ & $\begin{array}{c}194 \\
(383)\end{array}$ & $\begin{array}{c}35 \\
(334)\end{array}$ & $\begin{array}{c}25 \\
(526)\end{array}$ & $\begin{array}{c}106 \\
(134)\end{array}$ & $\begin{array}{c}213 \\
(534)\end{array}$ & $\begin{array}{c}28 \\
(168)\end{array}$ & $\begin{array}{c}48 \\
(546)\end{array}$ \\
\hline $\begin{array}{l}\text { Other input costs } \\
\text { (biocides, plant } \\
\text { growth regulators, } \\
\text { others) (USD/ha) }\end{array}$ & $\begin{array}{c}117 \\
(594)\end{array}$ & $\begin{array}{c}51 \\
(128)\end{array}$ & $\begin{array}{c}-43 \\
(700)\end{array}$ & $\begin{array}{c}17 \\
(250)\end{array}$ & $\begin{array}{c}122 \\
(692)\end{array}$ & $\begin{array}{c}107 \\
(303)\end{array}$ & $\begin{array}{c}-47 \\
(824)\end{array}$ & $\begin{array}{c}-33 \\
(313)\end{array}$ \\
\hline $\begin{array}{l}\text { Chemical fertilizer } \\
\text { costs (USD/ha) }\end{array}$ & $\begin{array}{c}711 \\
(927)\end{array}$ & $\begin{array}{c}934 \\
(2094)\end{array}$ & $\begin{array}{c}-101 \\
(1308)\end{array}$ & $\begin{array}{c}-46 \\
(2084)\end{array}$ & $\begin{array}{c}668 \\
(938)\end{array}$ & $\begin{array}{c}803 \\
(917)\end{array}$ & $\begin{array}{c}-20 \\
(1437)\end{array}$ & $\begin{array}{l}-275 \\
(988)\end{array}$ \\
\hline Organic fertilizer & 93 & 142 & 19 & -47 & $55 * *$ & 174 & 12 & 33 \\
\hline costs (USD/ha) & $(234)$ & (365) & (329) & (374) & (90) & (387) & $(132)$ & (558) \\
\hline Hired labor costs & 805 & 581 & -57 & -195 & 719 & 986 & -22 & -132 \\
\hline (USD/ha) & (1108) & (1122) & (1078) & (1104) & (947) & (1399) & (1037) & (1183) \\
\hline Other variable & $236 * * *$ & 536 & $51^{* *}$ & -206 & $140 * * *$ & 441 & 22 & 115 \\
\hline costs (USD/ha) & (346) & (951) & $(415)$ & (988) & (141) & $(527)$ & $(216)$ & $(668)$ \\
\hline $\begin{array}{l}\text { Total variable costs } \\
\text { (USD/ha) }\end{array}$ & $\begin{array}{l}2139 \\
(2015)\end{array}$ & $\begin{array}{c}2534 \\
(3340)\end{array}$ & $\begin{array}{c}136 \\
(2309)\end{array}$ & $\begin{array}{c}-447 \\
(3119)\end{array}$ & $\begin{array}{l}1803^{* *} \\
(1849)\end{array}$ & $\begin{array}{l}2855 \\
(2205)\end{array}$ & $\begin{array}{c}67 \\
(2283)\end{array}$ & $\begin{array}{c}284 \\
(2408)\end{array}$ \\
\hline $\begin{array}{l}\text { Net revenue } \\
\text { (USD/ha) }\end{array}$ & $\begin{array}{c}3898 \\
(4939)\end{array}$ & $\begin{array}{c}3707 \\
(7045)\end{array}$ & $\begin{array}{c}-150 \\
(5206)\end{array}$ & $\begin{array}{c}196 \\
(10,947)\end{array}$ & $\begin{array}{c}3565 \\
(4397)\end{array}$ & $\begin{array}{c}4607 \\
(5982)\end{array}$ & $\begin{array}{c}-83 \\
(4988)\end{array}$ & $\begin{array}{c}-292 \\
(5758)\end{array}$ \\
\hline
\end{tabular}

Notes: Standard deviations are shown in parentheses. *, **, *** imply the mean value in 2009 / the change from 2009 to 2010 is statistically different between certified and non-certified farmers/farmers certified in producermanaged groups and famers certified in exporter-managed groups at the $10 \%, 5 \%$ and $1 \%$ level, respectively.

Source: Own data

Table 10 shows differences and changes in annual net household income by activity. For the year 2009, we do not find significant differences in income levels between certified and noncertified producers for all income categories indicating that their income structures are relatively similar. Comparing income changes, we find that although certified producers on the average experienced an increase in net household income and net $F \& V$ income, whereas non-certified farmers experienced a decrease, these differences are not statistically significant. Similarly, comparing the net household income between certified farmers in exportermanaged groups and certified farmers in producer-managed groups, we do not find significant differences between the income levels of the two groups in 2009, nor do we find significant differences in changes in income between 2009 and 2010. 
Table 10: Annual net household income in US Dollars by activity

\begin{tabular}{|c|c|c|c|c|c|c|c|c|}
\hline & \multicolumn{2}{|c|}{ Year 2009} & \multicolumn{2}{|c|}{$\Delta$ 2010-2009 } & \multicolumn{2}{|c|}{ Year 2009} & \multicolumn{2}{|c|}{$\Delta$ 2010-2009 } \\
\hline & $\begin{array}{l}\text { Certified } \\
\text { farmers } \\
(\mathrm{N}=72)\end{array}$ & $\begin{array}{l}\text { Non- } \\
\text { certified } \\
\text { farmers } \\
(\mathrm{N}=142)\end{array}$ & $\begin{array}{c}\text { Certified } \\
\text { farmers } \\
(\mathrm{N}=72)\end{array}$ & $\begin{array}{c}\text { Non- } \\
\text { certified } \\
\text { farmers } \\
(\mathrm{N}=142)\end{array}$ & $\begin{array}{c}\text { Producer- } \\
\text { managed } \\
(\mathrm{N}=49)\end{array}$ & $\begin{array}{c}\text { Exporter- } \\
\text { managed } \\
(\mathrm{N}=23)\end{array}$ & $\begin{array}{c}\text { Producer- } \\
\text { managed } \\
(\mathrm{N}=49)\end{array}$ & $\begin{array}{c}\text { Exporter- } \\
\text { managed } \\
(\mathrm{N}=23)\end{array}$ \\
\hline $\begin{array}{l}\text { Net F\&V } \\
\text { income }\end{array}$ & $\begin{array}{c}5530 \\
(11,876)\end{array}$ & $\begin{array}{c}12,942 \\
(51,126)\end{array}$ & $\begin{array}{c}4484 \\
(19,279)\end{array}$ & $\begin{array}{c}-2766 \\
(50,672)\end{array}$ & $\begin{array}{c}5608 \\
(13,082)\end{array}$ & $\begin{array}{c}5360 \\
(9040)\end{array}$ & $\begin{array}{c}1739 \\
(10,783)\end{array}$ & $\begin{array}{c}5773 \\
(22,162)\end{array}$ \\
\hline $\begin{array}{l}\text { Net crop } \\
\text { income (except } \\
\text { F\&V) }\end{array}$ & $\begin{array}{l}1638 \\
(4609)\end{array}$ & $\begin{array}{c}1296 \\
(5145)\end{array}$ & $\begin{array}{c}214 \\
(4357)\end{array}$ & $\begin{array}{c}1189 \\
(10,323)\end{array}$ & $\begin{array}{c}1470 \\
(1957)\end{array}$ & $\begin{array}{c}1997 \\
(7747)\end{array}$ & $\begin{array}{c}316 \\
(4303)\end{array}$ & $\begin{array}{c}-3 \\
(4560)\end{array}$ \\
\hline $\begin{array}{l}\text { Net income } \\
\text { livestock \& } \\
\text { fishery }\end{array}$ & $\begin{array}{c}-188 \\
(1238)\end{array}$ & $\begin{array}{c}982 \\
(7747)\end{array}$ & $\begin{array}{c}292 \\
(2296)\end{array}$ & $\begin{array}{c}-706 \\
(8011)\end{array}$ & $\begin{array}{c}-302 \\
(1482)\end{array}$ & $\begin{array}{c}55 \\
(263)\end{array}$ & $\begin{array}{c}451 \\
(2772)\end{array}$ & $\begin{array}{c}-45 \\
(270)\end{array}$ \\
\hline $\begin{array}{l}\text { Off-farm } \\
\text { income }\end{array}$ & $\begin{array}{c}4198 \\
(10,793)\end{array}$ & $\begin{array}{c}3561 \\
(8611)\end{array}$ & $\begin{array}{c}970 \\
(7804)\end{array}$ & $\begin{array}{c}795 \\
(6925)\end{array}$ & $\begin{array}{c}4964 \\
(12,490)\end{array}$ & $\begin{array}{c}2564 \\
(5609)\end{array}$ & $\begin{array}{c}229 \\
(7745)\end{array}$ & $\begin{array}{c}2548 \\
(7864)\end{array}$ \\
\hline $\begin{array}{l}\text { Annual total net } \\
\text { household } \\
\text { income }\end{array}$ & $\begin{array}{c}11,177 \\
(18,998)\end{array}$ & $\begin{array}{c}18,776 \\
(53,612)\end{array}$ & $\begin{array}{c}5865 \\
(20,386)\end{array}$ & $\begin{array}{c}-1540 \\
(51,881)\end{array}$ & $\begin{array}{c}11,740 \\
(21,861)\end{array}$ & $\begin{array}{c}9976 \\
(10,950)\end{array}$ & $\begin{array}{c}6682 \\
(22,742)\end{array}$ & $\begin{array}{c}4125 \\
(14,425)\end{array}$ \\
\hline
\end{tabular}

Notes: Standard deviations are shown in parentheses. *, **, *** imply the mean value in 2009 / the change from 2009 to 2010 is statistically different between certified and non-certified farmers/farmers certified in producermanaged groups and famers certified in exporter-managed groups at the $10 \%, 5 \%$ and $1 \%$ level, respectively. Source: Own data

\subsubsection{Impact of GlobalGAP on producer prices}

In this section, we present the estimation results of the fixed effects model explaining $F \& V$ producer prices $^{56}$ (see Table 11). The first and the second specifications estimate the aggregate effect of GlobalGAP certification on F\&V producer prices and the third and fourth specifications analyze mean treatment effects for the subgroups of farmers certified in producer-managed and exporter-managed groups, respectively. Due to a potential correlation between the explanatory variables, specifications (1) and (3) only include a subset of the independent variables while specifications (2) and (4) control for all potential explanatory factors.

\footnotetext{
${ }^{56}$ To test whether the unobserved effect is correlated with the explanatory variables in our models, we employed the Hausman test. In specifications (1) to (3) in Table 11, the null hypothesis of zero correlation is rejected at the $5 \%$ level, while in specification (4) in Table 11, the null hypothesis is rejected at the $10 \%$ level. Hence, we conclude that the fixed effects model is more appropriate than the random effects model for our data.
} 
Table 11: Determinants of $F \& V$ producer prices

\begin{tabular}{|c|c|c|c|c|}
\hline & (1) & (2) & (3) & (4) \\
\hline GlobalGAP certified $(0 / 1)^{\mathrm{a}}$ & $\begin{array}{c}0.36^{* * *} \\
(0.12)\end{array}$ & $\begin{array}{c}0.20 \\
(0.12)\end{array}$ & - & - \\
\hline 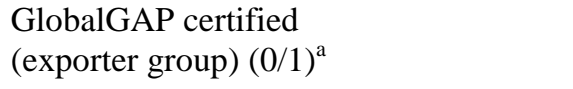 & - & - & $\begin{array}{c}-0.02 \\
(0.15)\end{array}$ & $\begin{array}{c}0.01 \\
(0.13)\end{array}$ \\
\hline 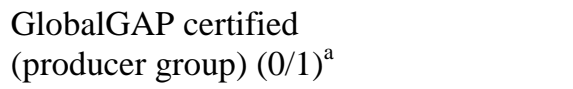 & - & - & $\begin{array}{c}0.52^{* * *} \\
(0.14)\end{array}$ & $\begin{array}{l}0.29 * \\
(0.15)\end{array}$ \\
\hline $\begin{array}{l}\text { Total quantity of F\&V sold } \\
\text { (1000 kg) }\end{array}$ & $\begin{array}{c}0.00 \\
(0.00)\end{array}$ & $\begin{array}{c}0.00 * * \\
(0.00)\end{array}$ & $\begin{array}{c}0.00 \\
(0.00)\end{array}$ & $\begin{array}{l}0.00 * \\
(0.00)\end{array}$ \\
\hline $\begin{array}{l}\text { Share of F\&V sold to high-value } \\
\text { markets }\end{array}$ & - & $\begin{array}{l}0.23 * * \\
(0.11)\end{array}$ & - & $\begin{array}{l}0.22 * * \\
(0.11)\end{array}$ \\
\hline Share of F\&V sold that is graded & - & $\begin{array}{l}0.45^{* *} \\
(0.21)\end{array}$ & - & $\begin{array}{c}0.45^{* *} \\
(0.21)\end{array}$ \\
\hline $\begin{array}{l}\text { Share of F\&V sold under a } \\
\text { market-specification contract }\end{array}$ & - & $\begin{array}{c}0.26^{* * *} \\
(0.10)\end{array}$ & - & $\begin{array}{l}0.25^{* *} \\
(0.11)\end{array}$ \\
\hline $\begin{array}{l}\text { Share of F\&V sold under a } \\
\text { production-management contract }\end{array}$ & - & $\begin{array}{c}0.15 \\
(0.11)\end{array}$ & - & $\begin{array}{c}0.15 \\
(0.11)\end{array}$ \\
\hline $\begin{array}{l}\text { Share of F\&V sold for which resources } \\
\text { are provided }\end{array}$ & - & $\begin{array}{l}-0.02 \\
(0.09)\end{array}$ & - & $\begin{array}{l}-0.01 \\
(0.10)\end{array}$ \\
\hline Year $2010(0 / 1)^{b}$ & $\begin{array}{c}0.26 * * * \\
(0.09)\end{array}$ & $\begin{array}{c}0.23 * * * \\
(0.07)\end{array}$ & $\begin{array}{c}0.26^{* * *} \\
(0.09)\end{array}$ & $\begin{array}{c}0.23 * * * \\
(0.07)\end{array}$ \\
\hline Constant & $\begin{array}{l}-1.34 \\
(2.08)\end{array}$ & $\begin{array}{c}1.20 \\
(1.53)\end{array}$ & $\begin{array}{l}-2.22 \\
(1.74)\end{array}$ & $\begin{array}{c}0.69 \\
(1.62) \\
\end{array}$ \\
\hline Number of observations & 406 & 406 & 406 & 406 \\
\hline R-squared & 0.46 & 0.55 & 0.47 & 0.55 \\
\hline
\end{tabular}

Notes: The dependent variable is log mean F\&V price. Coefficient estimates are shown with cluster robust standard errors in parentheses. Statistical significance at the $1 \%(* * *), 5 \%(* *)$ and $10 \%(*)$ levels. Variables capturing the share of different $\mathrm{F} \& \mathrm{~V}$ in the total quantity sold are included, but not shown due to space restrictions. The full model results are shown in Appendix III.

${ }^{\mathrm{a}}$ The reference group is non-certified farmers.

${ }^{\mathrm{b}}$ The reference year is 2009 .

Source: Own data

The results shown in column (1) of Table 11 confirm our expectation that GlobalGAP certification has a positive impact on prices. On the average, certification increases prices by $43 \%{ }^{57}$. Hence, the price increase we find is much larger than the price premium of $9.5 \%$ identified by Kariuki et al. (2012) in their study on the Kenyan French bean sector. Adding further explanatory variables on the marketing relationship to the model (see column 2), the coefficient for GlobalGAP certification decreases in size and becomes insignificant. This can be attributed to the correlation between GlobalGAP certification and several marketingrelated variables. As was shown in the descriptive statistics, farmers were able to increase their sales to high-value markets as a result of GlobalGAP certification. Results in column (2) reveal that the share of fruit and vegetables sold to high-value markets and the share of $F \& V$ sold that is graded have a large and significant positive impact on producer prices. Thus, our results indicate that much of the positive price effect from GlobalGAP certification is due to

\footnotetext{
${ }^{57}$ The exact percentage difference in the predicted price was calculated as follows for all explanatory variables: $100 *[\exp (\widehat{\beta} \Delta \mathrm{x})-1]$
} 
improved access to high value segments through which higher prices can be obtained. Furthermore, the type of contractual agreement has an influence on the prices received by farmers. Our results show that a $10 \%$ increase in the share of $F \& V$ sold under a marketspecification contract leads to an average price increase of $3 \%$.

Looking at subgroup-specific average treatment effects (column 3 of Table 11), we find that the observed increase in average prices resulting from GlobalGAP certification is mainly driven by significant price increases in the producer-managed groups. GlobalGAP certification in producer-managed groups has led to an average price increase of $68 \%$, while in exporter-managed groups there is no significant impact on prices. The coefficient for GlobalGAP certification in producer-managed groups remains marginally significant if further explanatory variables are added to the model (column 4 of Table 11), but the magnitude of the effect drops by more than half to $34 \%$.

The finding that there is no significant price increase for farmers certified in exportermanaged groups is in line with observations of qualitative studies, which show that exporters are usually not willing to pay price premiums for GlobalGAP-certified produce to farmers (Graffham et al., 2007b, Ouma, 2010). This suggests that, if costs of compliance are mainly paid for by buyers, these costs are implicitly deducted from product prices. Our results are also confirmed by the information collected in qualitative interviews with exporters involved in the development project in our study area. None of the exporters claimed to offer price premiums to farmers after successful certification, but rather continued to pay the same prices to certified and non-certified suppliers. According to the exporters, the main short-term benefits that farmers can derive from being included in the certification groups are knowledge gains as well as the advantages of being a preferred supplier.

\subsubsection{Impact of GlobalGAP on net household income}

Table 12 shows the results of the fixed effects model estimating farmers' net household income $^{58}$. Specifications (1) and (2) measure the average total effect of GlobalGAP

\footnotetext{
${ }^{58}$ To test whether the unobserved effect is correlated with the explanatory variables in our models, we employed the Hausman test. In all specifications shown in Table 12, we cannot reject the null hypothesis of zero correlation and random effects and fixed effects estimates are very similar. However, we do believe that GlobalGAP certification as well as certification in exporter-managed and producer-managed groups might be correlated with unobservable characteristics that also effect net household income, and hence decide to use the fixed effects approach.
} 
certification and the subgroup-specific mean effects of the standard on farmers certified in exporter-managed and producer-managed groups, respectively. In specifications (3) and (4) we additionally look at the per hectare effect of GlobalGAP certification.

Table 12: Determinants of net household income (USD)

\begin{tabular}{|c|c|c|c|c|}
\hline & \multicolumn{2}{|c|}{$\begin{array}{c}\text { Total effect of GlobalGAP } \\
\text { certification }\end{array}$} & \multicolumn{2}{|c|}{$\begin{array}{c}\text { Per hectare effect of } \\
\text { GlobalGAP certification }\end{array}$} \\
\hline & (1) & (2) & (3) & (4) \\
\hline $\begin{array}{l}\text { GlobalGAP } \\
\text { certified }(0 / 1)^{\mathrm{a}}\end{array}$ & $\begin{array}{c}10,039 * * * \\
(3800)\end{array}$ & - & $\begin{array}{c}3762 * * * \\
(1420)\end{array}$ & - \\
\hline $\begin{array}{l}\text { GlobalGAP certified } \\
\text { (exporter group) }(0 / 1)^{a}\end{array}$ & - & $\begin{array}{c}373 \\
(5071)\end{array}$ & - & $\begin{array}{c}2343 \\
(3311)\end{array}$ \\
\hline $\begin{array}{l}\text { GlobalGAP certified } \\
\text { (producer group) }(0 / 1)^{a}\end{array}$ & - & $\begin{array}{l}14,678 * * * \\
(5247)\end{array}$ & - & $\begin{array}{c}3792 * * * \\
(1460)\end{array}$ \\
\hline Cultivated area F\&V (ha) & $\begin{array}{l}1853 * * * \\
(735)\end{array}$ & $\begin{array}{c}1833 * * * \\
(730)\end{array}$ & $\begin{array}{l}2095 * * * \\
(652)\end{array}$ & $\begin{array}{c}2091 * * * \\
(652)\end{array}$ \\
\hline Cultivated area other products (ha) & $\begin{array}{l}1346 \\
(983)\end{array}$ & $\begin{array}{l}1392 \\
(993)\end{array}$ & $\begin{array}{l}1250 \\
(951)\end{array}$ & $\begin{array}{l}1254 \\
(954)\end{array}$ \\
\hline No. household members off-farm & $\begin{array}{l}8971^{* * *} \\
(4337)\end{array}$ & $\begin{array}{l}9135^{* *} \\
(4370)\end{array}$ & $\begin{array}{l}9650 * * \\
(4390)\end{array}$ & $\begin{array}{l}9664 * * \\
(4401)\end{array}$ \\
\hline No. of household members & $\begin{array}{l}-1086 \\
(1757)\end{array}$ & $\begin{array}{l}-1135 \\
(1762)\end{array}$ & $\begin{array}{l}-1145 \\
(1755)\end{array}$ & $\begin{array}{l}-1149 \\
(1758)\end{array}$ \\
\hline Drought in $2010(0 / 1)$ & $\begin{array}{l}-4873^{*} \\
(2550)\end{array}$ & $\begin{array}{c}-5645^{* * *} \\
(2761)\end{array}$ & $\begin{array}{l}-3917^{*} \\
(2344)\end{array}$ & $\begin{array}{l}-3914 * \\
(2346)\end{array}$ \\
\hline Constant & $\begin{array}{c}20,675 \\
(35,083)\end{array}$ & $\begin{array}{c}19,275 \\
(35,472)\end{array}$ & $\begin{array}{c}20,821 \\
(34,432)\end{array}$ & $\begin{array}{c}20,788 \\
(34,413)\end{array}$ \\
\hline Number of observations & 428 & 428 & 428 & 428 \\
\hline R-squared & 0.16 & 0.16 & 0.17 & 0.17 \\
\hline
\end{tabular}

Notes: The dependent variable is net household income in USD. Coefficient estimates are shown with cluster robust standard errors in parentheses. Variables capturing the share of area cultivated with different products are included, but not shown due to space restrictions. The full model results are shown in Appendix III.

Statistical significance at the $1 \%(* * *), 5 \%(* *)$ and $10 \%\left(^{*}\right)$ levels.

${ }^{\mathrm{a}}$ The reference group is non-certified farmers.

Our results show that GlobalGAP certification is a promising option for Thai fruit and vegetable farmers. On the average, GlobalGAP certification has increased farmers' annual net household income by 10,039 USD (column 1 of Table 12). Looking at per hectare effects in column 3, we find that one additional hectare of certified land leads to an average increase in net household income of 3762 USD. The results of the remaining explanatory variables are as expected. Off-farm employment generates particularly high returns: one additional household member working off-farm contributes to an average annual income increase of 8971 USD. This reflects the status of Thailand as an emerging market, where remunerative opportunities for off-farm activities are increasingly available and represent an important income source for rural households (Rigg and Nattapoolwat, 2001, Rigg, 2005). The coefficient for the cultivated area with $\mathrm{F} \& \mathrm{~V}$ is also positive and significant indicating that one additional hectare of land under F\&V increases net household income by 1853 USD. Moreover, farmers affected 
by the drought in 2010 have experienced large significant income losses of 4873 USD on the average.

Looking at heterogeneous impacts across certification groups (columns 2 and 4 of Table 12), we find that there are indeed differential effects for households certified in exporter-managed and producer-managed groups. While GlobalGAP certification in exporter-managed groups does not have a significant impact, GlobalGAP adoption in producer-managed groups has a positive and significant effect on farmers' net household income. On the average, GlobalGAP certification in producer-managed groups leads to 14,678 USD higher net household incomes and to an income increase of 3792 USD per hectare of land that is certified. These results are similar to our findings that price effects are positive and significant for farmers certified in producer-managed groups, but not for farmers certified in exporter-managed groups.

The large positive impact of GlobalGAP on the household income of farmers certified in producer-managed groups suggests that GlobalGAP certification can be profitable for smallscale farmers. However, it needs to be kept in mind that in the producer-managed groups in our sample, during the first year of adoption the recurrent costs of compliance, i.e., the costs for the external audit, for laboratory analyses and for running the QMS, were covered by the development program. Hence, if farmers renew the GlobalGAP certificate in the following years, these recurrent costs have to be deducted from their income. Without the continued support of the development program it is questionable whether farmers organized in producermanaged groups will take the risk to incur the costs of re-certification. Long-term links with downstream actors operating in high-value markets that provide a secure market outlet and premium prices are important incentives for farmers to continually comply with the GlobalGAP standard.

In the exporter-managed certification groups, the implementation of GlobalGAP certification has not induced many significant changes in outcome variables. Group members do not receive higher prices and have not been able to increase their sales to high-value markets. At the same time, variable costs per hectare have not risen significantly. In line with this, we do not find a significant effect of certification on net household incomes of producers certified in exporter-managed groups.

One shortcoming of our results is that they represent short-term effects only. In exportermanaged groups, where certification is mostly driven by buyers, farmers might experience positive income effects in the long run. For example, adjustments in farm management and 
production methods that are implemented in the context of GlobalGAP adoption might have a positive effect on product quality, which may only become visible after several growing periods. In addition, in the long run certified farmers might also benefit from increased and more stable demand for their products, allowing them to cultivate larger areas or to increase the number of production cycles. One of the exporter-managed groups, for example, grows green okra for export to Japan during the off-season when demand in Japan exceeds supply. With the GlobalGAP certificate, the exporter expects that okra can be sold year-round, even during the peak season when domestic production can almost satisfy consumer demand in Japan.

At the moment, while GlobalGAP is certainly an advantage, it is not an indispensable requirement to sell to lucrative markets in Thailand. The adoption of the standard is not very wide-spread yet, so that exporters are forced to also source from non-certified producers. All the exporters involved in the survey source produce from a large number of smallholders, but only a very small share of their suppliers is included in GlobalGAP certification schemes. As of mid 2010, all over Thailand only $776 \mathrm{~F} \& \mathrm{~V}$ producers were certified under GlobalGAP Option 2, and 31 farms, mostly exporter-owned and large-scale, were certified individually under Option 1 (FoodPLUS, 2010a). Our findings raise the question whether farmers in exporter-managed certification groups will continue to comply with GlobalGAP, if they do not receive any monetary benefits from certification in the short term. For Kenya, Graffham et al. (2007) report that a high share of smallholder farmers dropped out of exporter-managed certification schemes, because certification was not economically viable and external support was insufficient.

\subsection{Conclusions}

For the case of small-scale fruit and vegetable farmers in Thailand, we have analyzed the impact of GlobalGAP certification on F\&V product prices and farmers' net household income. While previous studies have only looked at the aggregate impacts of the standard, we find that the impact of GlobalGAP differs depending on whether certified farmers are organized in exporter-managed or producer-managed groups.

At the aggregate level, we can conclude that GlobalGAP has a significant impact on F\&V producer prices, leading to an average price increase of $43 \%$. However, whether GlobalGAP certification is rewarded by higher prices depends on the type of certification group and thus 
on the support received from downstream actors. Certified farmers in exporter-managed groups do not receive significant price premiums, whereas farmers in producer-managed groups were able to increase prices by $68 \%$ as a result of GlobalGAP certification. This can be explained by the fact that exporters covered the majority of compliance costs with GlobalGAP on behalf of their suppliers and hence were not willing to additionally reward farmers with higher prices. Our quantitative findings are supported by qualitative interviews with the exporters involved in the development program, who stated that they did indeed not pay price premiums specifically for GlobalGAP certification. Moreover, our results are in line with previous qualitative studies on the impacts of GlobalGAP adoption, which show that farmers identify the lack of price premiums as one of the major hurdles to the sustainable implementation of the GlobalGAP standard (Graffham et al., 2007b, Ouma, 2010).

Concerning the impacts of GlobalGAP on net household income, we find that while certified farmers in producer-managed groups have realized large net income gains, adopters in exporter-managed groups have not benefited from certification in terms of higher household incomes. This raises the question whether certification of smallholders in exporter-managed groups is economically viable for small-scale farmers. Currently, incentives for obtaining or sustaining GlobalGAP certification are small, especially because up until now, non-certified producers in Thailand are also able to sell their produce to high-value market outlets. One limitation of our study is, however, that we are only able to look at short-term effects. In the long run, farmers in exporter-managed groups might be able to realize positive income gains, e.g., through increased demand for their produce.

However, we can also conclude that under certain circumstances GlobalGAP certification can be profitable for smallholder farmers. In the producer-managed groups, certified farmers sold their produce to supermarkets, which paid substantial price premiums for GlobalGAP certified produce translating into significantly higher net incomes for farmers. The large income gains, however, were only possible because a major share of the recurrent costs of compliance were covered by the development project. After the end of the development project, it is questionable whether farmers will take the risk of incurring the high costs of certification in the absence of a safe market outlet. In this context, it is critical also for farmermanaged groups to have long-term contracts with exporters or supermarkets that reward GlobalGAP certified produce with price premiums. Furthermore, to make GlobalGAP certification of smallholders sustainable, continued access to affordable training and advice on 
the changing requirements of food safety and quality standards is necessary beyond the usually very limited duration of the development project. 


\title{
4. Is GlobalGAP certification of small-scale farmers sustainable? Evidence from
} Thailand

\begin{abstract}
This chapter presents a panel data analysis of the impacts of donor supported GlobalGAP certification on farmers' net household income and estimates the factors influencing continued compliance with the standard after the withdrawal of donor support. We find that adopters in exporter-managed certification groups and smaller farmers do not benefit from certification, whereas there is a large positive impact on farmers certified in producermanaged groups. Concerning the determinants of continued compliance, we conclude that adopters in producer-managed groups are less likely to become re-certified, while the support by exporters is the most important determinant influencing GlobalGAP re-certification.
\end{abstract}

Keywords: GlobalGAP, horticulture, development programs, sustainability, small-scale farmers, Thailand 


\subsection{Introduction}

In recent years, donors have increasingly focused on promoting high-value agriculture as a means to foster economic growth and to reduce poverty in rural areas (Gulati et al., 2006, Altenburg, 2006). The growing market for high-value agricultural products, such as fruits and vegetables, fish, meat and dairy products in both developed and developing countries creates new off-farm employment opportunities for low skilled laborers and offers the chance for small-scale farmers to increase their incomes (Weinberger and Lumpkin, 2007, Maertens and Swinnen, 2009, Gulati et al., 2006). However, there is mounting evidence that smallholders and in particular poorer farmers are excluded from supply chains because they cannot meet the increasingly stringent private standards for food safety and quality that are becoming mandatory to access high-value markets worldwide (Dolan and Humphrey, 2000, Farina and Reardon, 2000). Private standards were first imposed by major retailers and supermarket chains in industrialized countries in response to tightening public standards and to growing consumer concerns about food safety and quality (Henson and Reardon, 2005). More recently, compliance with private standards is also becoming a requirement for suppliers of domestic markets in developing countries. Supermarkets that already capture a large share of retail trade in many middle and low income countries increasingly use private standards as a competitive tool to differentiate their products from those offered in traditional markets (Henson and Reardon, 2005, Berdegue et al., 2005).

One of the most important private standards for primary producers is the GlobalGAP ${ }^{59}$ standard. GlobalGAP is a pre-farm gate standard for good agricultural practices and covers different aspects of food safety, environmental protection, traceability, workers' health and safety, and animal welfare (FoodPLUS, 2012a). The standard was developed by a coalition of European retailers in 1997 with the aim to harmonize retailers' existing minimum standards and today is the most widely implemented farm certification scheme (Will, 2010, Humphrey, 2008, FoodPLUS, 2012b). Several studies have shown that GlobalGAP adoption is particularly challenging for small-scale farmers and influenced by factors such as farm size, wealth, education, access to credits, extension services and trainings (Okello, 2005, Graffham et al., 2007b, Asfaw et al., 2009b, Kersting and Wollni, 2012). At the same time, however, studies have also shown that if farmers are able to comply, GlobalGAP implementation can

\footnotetext{
${ }^{59}$ Until 2007 the GlobalGAP standard was named EUREPGAP. In 2007 the name was changed to GlobalGAP to acknowledge the growing global significance of the standard (FoodPLUS, 2012b).
} 
lead to increased farm level productivity, better health and higher prices (Asfaw et al., 2009a, Asfaw et al., 2010, Kariuki et al., 2012).

Fearing the exclusion of smallholders from high-value supply chains as GlobalGAP became increasingly mandatory, several donors (e.g., DfID, GIZ, USAID) initiated development programs, which enabled many small-scale farmers and small and medium exporters to adopt the GlobalGAP standard. Donor support programs mainly focused on sub-Saharan Africa, but also on exporting countries in Latin America and Asia (Humphrey, 2008, Will, 2010). There is, however, increasing evidence that donor support may not always be sustainable and farmers often disadopt the GlobalGAP standard after donors withdraw their support (Graffham et al., 2007a, Bignebat and Vagneron, 2011). Although several studies provide such anecdotal evidence on the disadoption of the GlobalGAP standard, to the best of our knowledge no empirical analysis of the factors influencing continued compliance with GlobalGAP has yet been carried out.

This study aims to address this research gap by analyzing whether donor-assisted standard implementation among small-scale farmers is sustainable, i.e., whether farmers succeed to renew their certification after donor support ends. Our analysis is based on a unique panel data set of 218 Thai fruit and vegetable farmers that was collected in 2010 and 2011. In our sample, 72 farmers adopted the GlobalGAP standard with the support of a development program in 2010. However, only 18 of the 72 farmers were able to renew the certification one year later after donor support ended. Since the continued compliance with the GlobalGAP standard is likely to hinge upon the rewards that adopters derive from certification, we also focus on the costs and benefits of GlobalGAP adoption. First, we examine the annually recurring costs of compliance, second, we explore farmers' ex-ante and ex-post perceptions of the benefits of GlobalGAP adoption (i.e., before and after initial certification), and third, we estimate the impact of certification on farmers' net household income. In addition to the average treatment effects of GlobalGAP certification, we estimate subgroup-specific mean treatment effects, as the impact of the standard is likely to vary with farm size and across different certification models.

The chapter proceeds as follows. The next section discusses the implications of the GlobalGAP standard for small-scale farmers and the sustainability of donor interventions that support the certification of smallholders. Section 4.3. presents the sampling and survey design used for the study. Section 4.4. analyzes the costs, perceived benefits, and impacts of GlobalGAP certification. In section 4.5., we estimate the determinants of adoption and 
continued compliance with GlobalGAP. Section 4.6. derives policy implications and summarizes the main conclusions of this chapter.

\subsection{The GlobalGAP standard, small-scale farmers and donor support}

In 2005, several retailers in the European Union (EU) made compliance with the GlobalGAP standard a mandatory requirement for their suppliers. For small-scale farmers in developing countries this poses a threat of exclusion from lucrative export horticulture supply chains (Humphrey, 2008). Obtaining GlobalGAP certification can be very challenging for farmers in developing countries. Depending on their initial situation, it may require adjustments in farm management and production and oftentimes large investments in farm infrastructure and equipment, such as pesticide storage, sanitary facilities, chemical sprayer equipment and pesticide disposal pits (Asfaw et al., 2009b, Mausch et al., 2009, Chemnitz et al., 2007). For small-scale farmers, the financial burden of adopting GlobalGAP is particularly high, since the costs of compliance are to a large extent fixed costs. In addition, smallholders often have only limited access to liquidity or credit to finance these high initial investments (Asfaw et al., 2009b, Narrod et al., 2009, Okello, 2005, Mausch et al., 2009). Furthermore, GlobalGAP requires the implementation of practices such as integrated pest management, traceability and record keeping. These practices are often not known or not yet applied by small-scale farmers and the access to extension services that provide information and trainings on these topics is limited in most developing countries (Humphrey, 2008).

Recognizing these barriers to adoption several donors have implemented development programs supporting small-scale farmers to adopt the GlobalGAP standard. Donor interventions usually focus on GlobalGAP group certification, which can make certification feasible for smallholders. In particular, group certification exploits scale economies by centralizing requirements (e.g., establishing joint pesticide storage) and reduces individual certification fees, as only the square root of group members is checked during the external audit. Furthermore, a group structure reduces the transaction costs of dealing with large numbers of dispersed smallholders and thus also makes the provision of advice and trainings more viable (Will, 2010). However, obtaining GlobalGAP group certification is by no means less challenging than compliance at the individual level. Farmer groups must implement a Quality Management System (QMS) that guarantees that all members comply with the GlobalGAP standard, even though only a random sample of group members is inspected 
during the external audit. Implementing and running the QMS is a costly, time consuming and administratively challenging task that usually cannot be undertaken by smallholders alone (Humphrey, 2008, Will, 2010). In practice, different group certification models that vary with respect to the institutional arrangement for the QMS have been implemented and supported by donors (Humphrey, 2008, Will, 2010, Graffham et al., 2007b). One model often applied is a producer-managed group, where a cooperative or farmers' association runs the QMS (in some cases with the support of a donor) and owns the GlobalGAP certificate. An alternative model is an outgrower-scheme of an exporter, where the exporter manages the farmer group and owns the certificate (GTZ, 2010). Donor support usually extends to the formation of farmer groups, the implementation of GlobalGAP requirements at the farm level, and the development and operation of the QMS. Besides financial support that partially covers compliance and certification costs, donors often offer technical assistance and training programs to both farmers and exporters (Will, 2010, Humphrey, 2008, Graffham et al., 2007b).

Even if barriers to initial adoption can be successfully addressed through these support programs, the question remains in how far donor-assisted standard adoption is sustainable in the long run. Recent evidence suggests that donor subsidies of the initial costs of GlobalGAP adoption may well enable disadvantaged farmers and exporters to achieve certification, but they may still not be able to maintain the standard without continued support. Graffham, Karehu \& MacGregor (2007), e.g., describe eleven case studies of exporter outgrower schemes in Kenya that achieved GlobalGAP adoption with the support of donors. However, of the eleven certification groups only two were running sustainably and these were managed by the two largest exporters in Kenya. Similarly, for the case of Madagascar, Bignebat \& Vagneron (2011) report that of 1198 lychee producers that were certified at the height of GlobalGAP related donor interventions in 2007/2008 only 120 remained certified after the withdrawal of donors in 2009. Several reasons are discussed that may explain the limited sustainability of donor-assisted GlobalGAP certification. A key concern is whether farmers indeed derive monetary benefits from certification that make the renewal of the certification worthwhile. An important aspect may be the fact that there are high recurrent costs of compliance, such as the costs of the external audit and the operation of the QMS, that have to be incurred annually. Even though these are usually lower than the initial investment costs, they can still amount to a substantial share of farmers' revenues and thus represent a barrier to the renewal of the certification once donor support ends. Another potential reason for the disadoption of standards may be the lack of important value chain linkages. If during the 
support phase the focus lies exclusively on upgrading farm-level processes, an important opportunity may be missed to build long-term partnerships that facilitate farmers' access to high-value export markets. Last but not least, if quality management systems are not sufficiently developed and QMS staff is not adequately qualified at the time of donor withdrawal, groups are likely to lack the capacities to run the QMS in the absence of external support (Graffham et al., 2007b, Humphrey, 2008).

\subsection{Sampling and survey design}

To analyze the impact of certification on farmers' incomes and to identify the determinants of sustainable implementation of the GlobalGAP standard we carried out a panel data survey of Thai fruit and vegetable farmers in 2010 and 2011. The survey collected comprehensive quantitative and qualitative information on a wide range of topics, including socio-economic and farm characteristics, agricultural production and input use, marketing decisions, compliance with standards, group membership and participation in trainings. The first survey covers a one-year interval from March 2009 to the end of February 2010 and represents the time period before GlobalGAP certification for adopters in our sample. GlobalGAP certification took place in the first half of 2010, and thus the second survey covering the period from March 2010 to February 2011 corresponds to the situation after GlobalGAP adoption. In the remainder of this chapter, we will refer to the first survey interval as 2009 and to the second survey interval as 2010.

In our research area a development program was implemented that supported small-scale farmers to obtain GlobalGAP certification. During the preparation phase of the first survey round, the project was ongoing and none of the participants had been certified. Hence, we divided our study population into four strata (1) program participants who are likely to adopt GlobalGAP (N=118), (2) program participants who are not likely to achieve GlobalGAP certification ( $\mathrm{N}=237)$, (3) non-participants in program regions ( $\mathrm{N}=$ approx. 710 ), and (4) nonparticipants outside program regions ( $\mathrm{N}=$ approx. 415).

For the sampling of program participants, we were provided with a complete list of all participants, including their location and anticipated adoption status ${ }^{60}$. In order to have a

\footnotetext{
${ }^{60}$ During the preparation phase of the first survey in the beginning of 2010, 118 households were listed as prospective adopters by the development project. At this stage, farmers were classified as likely adopters if they were in the adoption process and expected to achieve certification in mid 2010, i.e. within the duration of the development project. By the end of the project, only 82 of the 118 adopters achieved certification.
} 
sufficiently large number of adopters for our analysis, we decided to include all prospective GlobalGAP adopters in our sample. Of the 118 households listed as prospective adopters, 97 were available for interviews. In addition, we randomly selected 49 program participants from the list of likely non-adopters.

For the control group complete lists were not available. Therefore, we used the random walk method to sample non-participants. For the internal control group, non-participating households were sampled in program villages, provided that they produce at least one of the products considered for GlobalGAP certification by program participants in the respective village $^{61}$. Since our internal control group is exposed to the activities of the development program and thus potentially affected by spillover effects, we additionally sampled nonparticipating households outside the program region. For this purpose, we identified ten districts that have similar agro-ecological conditions as the program districts and that are also major production areas for the products considered for GlobalGAP certification in the development program. The selection of these districts was accomplished in close consultation with local experts including Thai professors of agriculture and stakeholders of the development program. In total, we interviewed 287 farmers in 2010 of which 146 are program participants, 85 are non-participants within the program region, and 56 are non-participants outside the program region. In the econometric analysis, we use sampling weights ${ }^{62}$ to account for the oversampling of program participants in general and prospective adopters in particular.

In the follow-up survey that was carried out in 2011, we were able to reach $76 \%$ of the 287 households that were interviewed in the first survey round. Of the 218 households interviewed in the second survey round, 124 are program participants, 56 are non-participants in program regions and 34 are non-participants outside program regions. We only include 214 households in the analysis, because four of the interviewed households stopped to cultivate fruit and vegetables $(\mathrm{F} \& \mathrm{~V})$ during the study period.

There are several reasons for the occurrence of sampling attrition in the second survey round. First, for some of the households the contact information given was incorrect or they have moved away, and second, some households were not available for interviews. The results of

\footnotetext{
${ }^{61}$ The following products were selected for certification: lychee, durian, mangosteen, papaya, dragon fruit, cantaloupe, mango, asparagus, green okra, spring onion, yard long bean, different kinds of herbs and green leafy vegetables.

${ }^{62}$ Sampling weights are calculated as the inverse of the sampling fraction, i.e., the total number of households in each population divided by the number of samples drawn from that population.
} 
attrition probit tests (Fitzgerald et al., 1998) and pooled tests (Becketti et al., 1988) revealed that attrition in our study is nonrandom and significantly influenced by the age of the household head, the location of the household and by participation in the development project. Therefore, we use inverse probability weights ${ }^{63}$ that correct for sampling attrition that is based on observable characteristics. Inverse probability weights give more weight to individuals who are likely to attrit than to households that are likely to remain in the sample (Baulch and Quisumbing, 2011).

\subsection{The costs and benefits of GlobalGAP}

An important aspect of the long-term sustainability of GlobalGAP certification among smallscale farmers in developing countries concerns the economic rewards that farmers derive from certification. Farmers will only decide to maintain their certification, if the benefits from standard compliance exceed the costs of compliance (Henson et al., 2011). In the following section, we first discuss the relevance of recurrent costs for the sustainability of standard implementation. Secondly, we examine how farmers' perceived benefits of certification have changed over the study period, i.e., from before to after the initial certification. Finally, we present a fixed effects model estimating the impact of GlobalGAP certification on farmers' net household income.

\subsubsection{Recurrent costs of compliance}

While the initial investment costs have been identified as one of the main barriers to GlobalGAP adoption, the recurrent costs of compliance are discussed to be the most important factor determining the long-term viability of standard implementation (Asfaw et al., 2009b, Graffham et al., 2007b, Chemnitz et al., 2007). Recurrent costs include among others the costs for the external audit, the management of the QMS, laboratory analyses, trainings, as well as replacement and maintenance costs and have to be incurred on a regular basis. Donor interventions usually support farmers’ and exporters’ initial investments necessary to comply

\footnotetext{
${ }^{63}$ Weights are calculated as follows. First, the predicted probabilities of the unrestricted retention probit model are estimated using explanatory variables that are observable for both attritor and non-attritor households and that might be correlated with the likelihood of attrition. Then the model is re-estimated as a restricted model including only those explanatory variables that are not significantly associated with attrition. The inverse probability weights are then calculated as the ratio of the restricted to the unrestricted probabilities (Baulch and Quisumbing, 2011). Results of the attrition tests are presented in Appendix II.
} 
with the GlobalGAP regulations and cover the costs for the operation of the QMS and the external audit during the first year (Graffham et al., 2007b, Will, 2010). After the withdrawal of donors, however, the recurrent costs of compliance have to be fully borne by producers. This is particularly relevant for farmers certified in producer-managed groups, who have to bear the total amount of recurrent costs, whereas in exporter-managed certification groups the company usually covers a substantial share of the costs (Graffham et al., 2007b, Kersting and Wollni, 2012).

Table 13 presents the average recurrent costs of compliance per farmer for our sample of 72 GlobalGAP certified producers. Estimates are based on information provided by exporters and farmer groups, given that producers did not pay these costs during the first year. We treat the recurrent costs of compliance as fixed costs, because except for the maintenance and replacement costs, which may vary slightly between smaller and larger producers, the remaining costs are fixed. On the average, the recurrent costs per farmer add up to 778 USD. For those farmers in our sample organized in exporter-managed groups, a considerable share of these costs is absorbed by exporters leaving only 109 USD or 14\% of the total recurrent costs at the expense of the farmer. These estimates are similar to results presented by Graffham, Karehu et al. (2007), who show for the case of Kenya that in exporter-managed certification groups the companies paid $£ 760$ per farmer (86\% of the total recurrent costs), whereas farmers paid $£ 104$ (14\% of the total recurrent costs) on the average.

Table 13: Recurrent costs of compliance

\begin{tabular}{lccc}
\hline & $\begin{array}{c}\text { Recurrent costs } \\
\text { per farmer in } \\
\text { USD }\end{array}$ & $\begin{array}{c}\text { Percentage of } \\
\text { recurrent costs }\end{array}$ & $\begin{array}{c}\text { Paid by exporter } \\
\text { (if exporter- } \\
\text { managed) }\end{array}$ \\
\hline Certification and external audit & 263 & $34 \%$ & $\checkmark$ \\
Operation of the QMS, internal inspections \& audits & 154 & $20 \%$ & $\checkmark$ \\
$\begin{array}{l}\text { Annual refresher trainings (farmers and QMS) } \\
\text { Laboratory analyses (pesticide residue, water and soil } \\
\text { analyses) }\end{array}$ & 129 & $17 \%$ & $\checkmark$ \\
Health checks for staff working with pesticides & 51 & $15 \%$ & $\checkmark$ \\
Maintenance of structures & 32 & $7 \%$ & $\times$ \\
Replacement of protective clothing & 15 & $2 \%$ & $\times$ \\
Refill first aid kits, disinfectant and soap & 11 & $1 \%$ & $\checkmark$ \\
Record keeping forms, replacement of posters \& & 7 & $1 \%$ & \\
signs, plot markers & $\mathbf{7 7 8}$ & $\mathbf{1 0 0}$ & \\
\hline Total annual recurrent costs & & \\
\hline
\end{tabular}

Source: Own data

If the recurrent costs of compliance account for a large share of farmers' net income from fruit and vegetables, certification is not likely to be economically viable in the long run. Given that the recurrent costs are to a large extent fixed costs, this is of particular relevance for 
small-scale farmers. We therefore estimate the recurrent costs as a percentage of total net $\mathrm{F} \& \mathrm{~V}$ income ${ }^{64}$ by land size quartile of GlobalGAP adopters. Quartiles are based on the certified area planted between March 2010 and February 2011, i.e., during the time period covered by the second survey round. If plots are cultivated multiple times, the certified area is multiplied by the number of harvests. Table 14 presents the minimum, maximum and average size of the certified area and the average net $F \& V$ income for the total sample and for each of the quartiles. The certified area ranges from an average of 0.44 ha in the first quartile to 6.39 ha in the fourth quartile. Moreover, we can see that the net F\&V income of the first three quartiles is 2784 USD, 3556 USD, and 5606 USD, respectively, which seems substantially below the average net F\&V income of 28,675 USD in the largest quartile. Using Bonferroni tests to compare the differences in means between quartiles, we find that the first three quartiles are relatively homogeneous with respect to the size of the certified area and the total net income from F\&V. The fourth quartile, however, is statistically different from the first three quartiles in regard to both indicators.

Table 14: Certified area and net $F \& V$ income by quartile (in 2010)

\begin{tabular}{lccccc}
\hline & $\begin{array}{c}\text { Full sample } \\
\text { of adopters } \\
\mathbf{( N = 7 2 )}\end{array}$ & $\begin{array}{c}\text { First } \\
\text { quartile } \\
\mathbf{( N = 1 8 )}\end{array}$ & $\begin{array}{c}\text { Second } \\
\text { quartile } \\
\mathbf{( N = 2 3 )}\end{array}$ & $\begin{array}{c}\text { Third quartile } \\
\mathbf{( N = 1 3 )}\end{array}$ & $\begin{array}{c}\text { Fourth } \\
\text { quartile } \\
(\mathbf{N = 1 8 )}\end{array}$ \\
\hline Min-max certified & $0.16-$ & $0.16-$ & $0.64-$ & $1.12-$ & $1.91-$ \\
area (ha) & 33.92 & 0.56 & 0.96 & 1.6 & 33.92 \\
Mean certified & 2.21 & $0.44^{\mathrm{a}^{* * *}}$ & $0.75^{\mathrm{b}^{* * *}}$ & $1.47^{\mathrm{c}^{* * *}}$ & 6.39 \\
area (ha) & $(0.46)$ & $(0.09)$ & $(0.14)$ & $(0.16)$ & $(8.56)$ \\
Mean net F\&V & 10,013 & $2784^{\mathrm{a}^{* *}}$ & $3556 \mathrm{~b}^{\mathrm{a}^{* *}}$ & $5606^{\mathrm{c}^{*}}$ & 28,675 \\
income (USD) & $(27,410)$ & $(4549)$ & $(4179)$ & $(8179)$ & $(50,516)$ \\
\hline
\end{tabular}

Notes: Statistical significance at the $1 \%(* * *), 5 \%\left(^{* *}\right)$, and $10 \%\left(^{*}\right)$ levels.

${ }^{a}$ Difference statistically significant between first quartile and fourth quartile.

${ }^{\mathrm{b}}$ Difference statistically significant between second quartile and fourth quartile.

${ }^{\mathrm{c}}$ Difference statistically significant between third quartile and fourth quartile.

${ }^{\mathrm{d}}$ Standard deviations are shown in parentheses.

Source: Own data

Figure 3 illustrates the recurrent costs as a percentage of net $F \& V$ income for the whole sample of adopters and for each quartile. Average values are compared between farmers organized in producer-managed and exporter-managed certification groups. On the average, the recurrent costs account for $8 \%$ of net $\mathrm{F} \& \mathrm{~V}$ income in the case of farmer-managed certification groups and for $1 \%$ in the case of exporter-managed groups. However, these average figures conceal considerable variation among quartiles of adopters. In the case of

\footnotetext{
${ }^{64}$ Net income from $F \& V$ is defined as F\&V revenue minus variable costs.
} 
exporter-managed groups, the recurrent costs account for a relatively small share of net $\mathrm{F} \& \mathrm{~V}$ income in all four quartiles, ranging from $0.4 \%$ in the largest quartile to $7 \%$ in the smallest quartile. Similarly, in producer-managed groups for farmers in the largest quartile, the share of $3 \%$ is still modest. However, in the smaller quartiles recurrent costs account for $28 \%, 22 \%$, and $14 \%$ in the first, second, and third quartile, respectively. Among these small-scale farmers organized in producer-managed groups the recurrent costs are likely to represent a nonnegligible burden and thus potentially a barrier to re-certification in the absence of donor support.

Figure 3: Recurrent costs as percentage of net $F \& V$ income

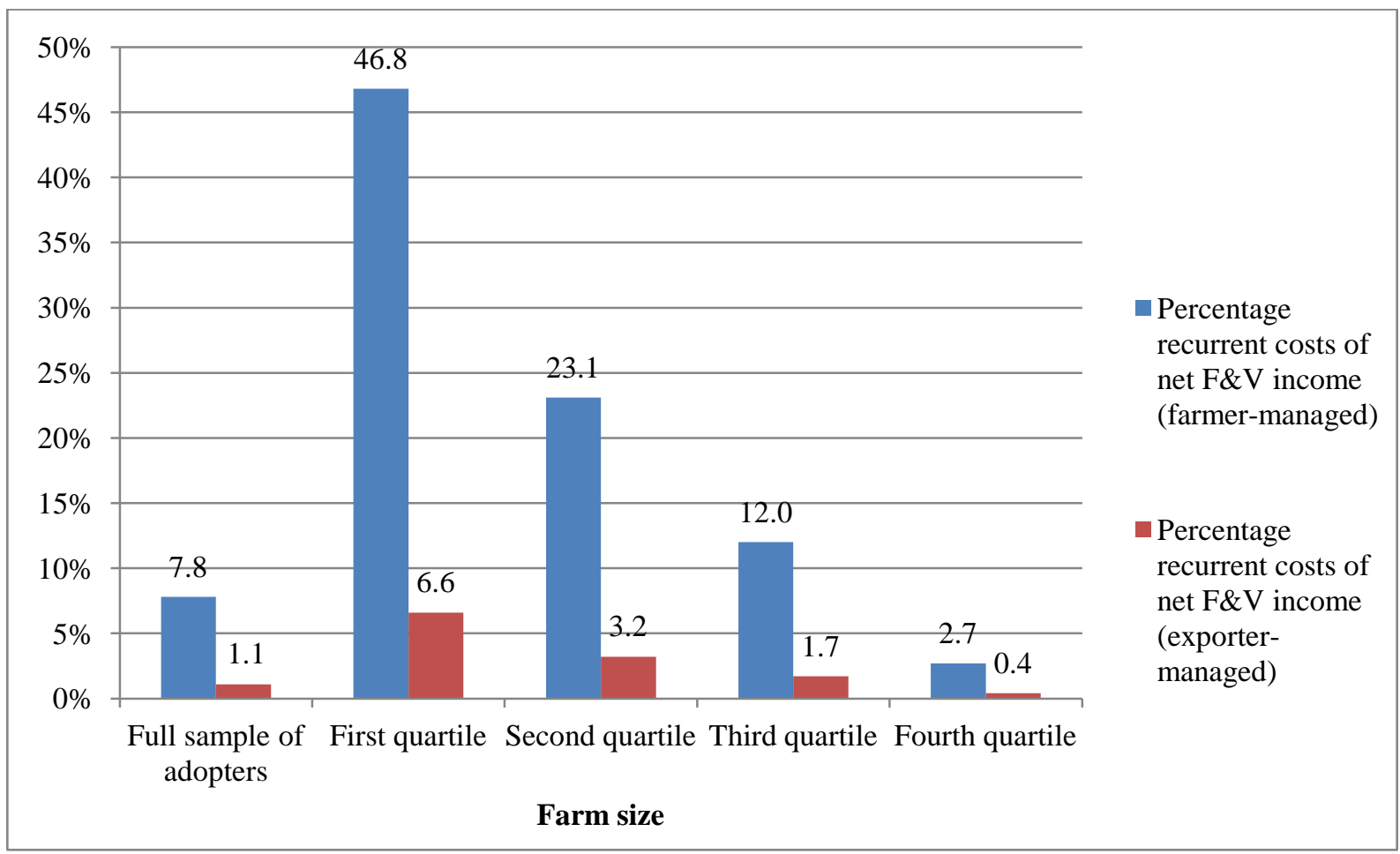

Source: Own data

\subsubsection{Perceived benefits of GlobalGAP adoption}

To assess what farmers' perceptions are regarding the benefits of complying with GlobalGAP and in how far their initial expectations are met, we collected qualitative information on perceived benefits as part of the household survey. During the first survey, i.e., before certification, we asked farmers to name the benefits they expect to obtain from GlobalGAP certification, while in the second round, i.e., after certification, they were asked to name the benefits that they actually experienced as a result of certification. The answers given by the certified farmers in our sample are presented in Table 15. 
Over the study period, the percentage of farmers perceiving a certain benefit as a result of GlobalGAP certification was reduced in all response categories. This indicates that farmers had high expectations before certification, which in several cases were not met. In particular, farmers' initial expectations that the adoption of the GlobalGAP standard would lead to a decrease in the costs of chemicals and to an increase in the quality of the produce did often not materialize. In fact, although GlobalGAP adoption may contribute to a reduction in the quantity of chemicals applied, those chemicals that farmers are still allowed to use in accordance with GlobalGAP regulations are usually more expensive than regularly available chemicals (Asfaw et al., 2009a). Moreover, some of the quality improvements that could potentially result from standard-compliant practices, like optimized irrigation and fertilizer regimes, may not be directly visible to farmers.

Still, in the second survey round farmers mentioned several benefits that they perceive to be a result of certification. Most of those benefits are related to the marketing of their produce: $77 \%$ of respondents agree with the statement that GlobalGAP makes finding buyers easier, $58 \%$ think that certification increases their access to high-value markets, $56 \%$ were able to secure a price premium, and $48 \%$ benefit from a purchase guarantee. Furthermore, $63 \%$ of the respondents indicated that they benefit from the use of enhanced management practices implemented as requirement of the GlobalGAP standard. Another 61\% perceive the improved health of family members and farm workers as an important benefit that results from following the GlobalGAP regulations on safe handling of pesticides.

Table 15: Farmers' perceived benefits of GlobalGAP compliance

\begin{tabular}{lcccccc}
\hline & \multicolumn{2}{c}{ Year 2009 } & & \multicolumn{2}{c}{ Year 2010 } \\
\cline { 2 - 3 } \cline { 5 - 6 } & $\begin{array}{c}\text { Number of } \\
\text { farmers } \\
\text { (N=57) }\end{array}$ & \% & & $\begin{array}{c}\text { Number of } \\
\text { farmers } \\
\text { (N=57) }\end{array}$ & \% \\
\hline Make finding buyers easier & 45 & 78 & & 44 & 77 \\
Enhance management practices & 46 & 81 & & 36 & 63 \\
Enhance family's and farm workers' health & 49 & 86 & & 35 & 61 \\
Increase access to high-value markets & 41 & 72 & & 33 & 58 \\
Buyer offered a price premium & 29 & 51 & & 32 & 56 \\
Buyer offered a purchase guarantee & 40 & 70 & & 26 & 46 \\
Decrease costs for chemicals & 50 & 88 & & 23 & 40 \\
Increase the quality of the produce & 50 & 88 & & 21 & 37 \\
Enhance bargaining power & 29 & 51 & & 21 & 37 \\
\hline
\end{tabular}

Note: Farmers were asked to indicate their perceived benefits of GlobalGAP certification.

Multiple options were possible.

Source: Own data 


\subsubsection{The impact of GlobalGAP certification on household income}

In the following subchapter, we empirically analyze the impact of GlobalGAP certification on farmers' net household income ${ }^{65}$. Previous studies on the impacts of GlobalGAP adoption have estimated average treatment effects (Asfaw et al., 2010, Asfaw et al., 2009a, Kariuki et al., 2012, Subervie and Vagneron, 2012) - this approach, however, disregards important distributional effects of the treatment (Heckman et al., 1997). The impact of GlobalGAP certification is likely to be heterogeneous across households and subgroups of adopters. Therefore, in addition to estimating the average treatment effect of GlobalGAP adoption, we look at mean treatment effects within subgroups of certified farmers. In particular, we are interested in estimating subgroup specific treatment effects for farmers certified in different types of certification groups (i.e., producer-managed versus exporter-managed groups) and for large-scale versus small-scale farmers.

In addition, we analyze the impact of GlobalGAP certification under two different scenarios. In the first scenario, we disregard the recurrent costs of compliance since during our survey period these did not have to be covered by farmers. During the first year of certification the recurrent costs were paid partly by the development program and partly by exporters. In the following years, however, farmers will have to bear the recurrent costs themselves, if they want to renew their certification. Consequently, the recurrent costs that are relevant for the decision to become re-certified are taken into account in the second scenario. In this scenario, we deduct the estimated recurrent costs of compliance (see chapter 4.4.1.) from the net household income of certified farmers.

Table 16 shows simple descriptive statistics of farmers' net household income in 2009 and 2010. We find that the overall net income of households in our sample increased by 951 USD over the study period. However, non-certified farmers experienced an income decrease of 1540 USD on the average, whereas certified farmers experienced substantial income increases of 5865 USD on the average. Within the sample of adopters, we find that farmers certified in producer-managed groups realized slightly higher average income gains than adopters in exporter-managed groups. Furthermore, we find considerable differences in the magnitude of the income increase between larger and smaller farmers. While the largest $25 \%$ of certified

\footnotetext{
${ }^{65}$ Net household income is calculated as net farm income (total farm revenue minus variable costs) plus wages and salaries from off-farm employment and net returns from self-employment. Unfortunately, we do not have information on the amount of remittances received by households and therefore cannot account for their value in the calculation of net household income.
} 
farmers were able to increase their income by 17,855 USD, the smallest $75 \%$ of certified producers increased their income by only 1869 USD on the average.

Table 16: Descriptive statistics - Net household income (in USD)

\begin{tabular}{lccc}
\hline & $\mathbf{2 0 0 9}$ & $\mathbf{2 0 1 0}$ & $\mathbf{\Delta ~ 2 0 1 0 - 2 0 0 9}$ \\
\hline Full sample (N=214) & 16,219 & 17,170 & 951 \\
& $(45,121)$ & $(27,980)$ & $(43,961)$ \\
Non-certified farmers (N=142) & 18,776 & 17,235 & -1540 \\
& $(53,612)$ & $(26,146)$ & $(51,881)$ \\
GlobalGAP certified & 11,177 & 17,042 & 5865 \\
farmers (N=72) & $(18,998)$ & $(31,479)$ & $(20,386)$ \\
GlobalGAP certified & 9976 & 14,101 & 4125 \\
(exporter group) (N=23) & $(10,950)$ & $(12,790)$ & $(14,425)$ \\
GlobalGAP certified & 11,741 & 18,423 & 6682 \\
(producer-group) (N=49) & $(21,861)$ & $(37,211)$ & $(22,742)$ \\
GlobalGAP certified & 7757 & 9626 & 1869 \\
(smallest 75\%) (N=54) & $(8568)$ & $(11,339)$ & $(13081)$ \\
GlobalGAP certified & 21,436 & 39,292 & 17,855 \\
(largest 25\%) (N=18) & $(33,614)$ & $(55,126)$ & $(31,610)$ \\
\hline
\end{tabular}

Note: Standard deviations are shown in parentheses.

Source: Own data

While these simple descriptive statistics may indicate some tendencies in the distribution of impacts, they do not control for potential confounding factors, including attrition bias and selection bias. In the next section, we address these issues using an econometric model to estimate income effects of certification.

\subsubsection{Econometric approach to analyze income effects}

We specify three panel data models to estimate (1) the average treatment effect of GlobalGAP certification, (2) the impact of certification on farmers organized in exporter-managed and producer-managed groups and (3) the effect of GlobalGAP on smaller and larger farmers certified in different types of certification groups.

The model to analyze the average treatment effect of GlobalGAP certification on farmers' net household income is specified as follows:

(1) $y_{i t}=\beta G_{i t}+\boldsymbol{\delta} \boldsymbol{X}_{i t}+c_{i}+u_{i t}$ 
where $y_{i t}$ indicates net household income that varies across individual households $i$ and over time $t, G_{i t}$ is a dummy that is equal to one if farmer $i$ is certified in year $t^{66}, \boldsymbol{X}_{i t}$ is a vector of explanatory variables, $c_{i}$ is the time constant unobserved effect and $u_{i t}$ the idiosyncratic error.

GlobalGAP certification can affect household income through various channels. Overall, we expect the effect to be positive. Certification can be perceived as a signal informing potential buyers in high-value markets that the farmer is a high-quality, safety-compliant producer. This may then improve access to high-value markets and lead to price premiums for higher quality and compliance with food safety regulations (Fafchamps et al., 2008, Kariuki et al., 2012). Given better access to high-value markets, farmers may specialize or intensify their $\mathrm{F} \& \mathrm{~V}$ production resulting in larger quantities sold in the market. On the other hand, there may also be negative income effects, if farmers as a result of certification re-allocate their labor or other productive resources away from more profitable uses. In particular, GlobalGAP adoption may lead to increased labor demand to perform labor-intensive practices such as integrated pest management and record keeping and higher expenses for crop protection products. Furthermore, high recurrent costs of compliance can offset income increases, if they have to be borne by farmers.

In addition to average treatment effects, we are interested in estimating mean treatment effects for subgroups of adopters. GlobalGAP certification can be implemented within different business models and we hypothesize that impacts differ depending on whether farmers are organized in exporter-managed or producer-managed certification groups. To test this hypothesis, the following model is specified:

(2) $y_{i t}=\beta_{1} G_{i t}^{E}+\beta_{2} G_{i t}^{P}+\boldsymbol{\delta} \boldsymbol{X}_{i t}+c_{i}+u_{i t}$,

where $G_{i t}^{E}$ is a dummy that equals one if farmer $i$ is certified in an exporter-managed group in year $t$. The variable $G_{i t}^{P}$ is defined analogously for farmers certified in producer-managed groups.

\footnotetext{
${ }^{66}$ Although six farmers were certified in both time periods, we define all farmers as non-adopters during the first survey period. Otherwise, due to the time-demeaning in the fixed effects model, farmers who are certified in both 2009 and 2010 are considered non-adopters. We decided to classify these six farmers as adopters, because we expect them to realize positive income gains that can be attributed to the renewal of the GlobalGAP certificate.
} 
Furthermore, the effects of GlobalGAP certification may be heterogeneous across smaller and larger farmers certified in the different types of certification groups. We test these effects with the following model specification:

(3) $y_{i t}=\beta_{3} G_{i t}^{E \times S(75 \%)}+\beta_{4} G_{i t}^{E \times L(25 \%)}+\beta_{5} G_{i t}^{P \times S(75 \%)}+\beta_{6} G_{i t}^{P \times L(25 \%)} \boldsymbol{\delta} \boldsymbol{X}_{i t}+c_{i}+u_{i t}$,

where $G_{i t}^{E \times S(75 \%)}$ is a dummy that equals one if farmer $i$ belongs to the smallest $75 \%$ of certified farmers and is certified in an exporter managed group in year $t$. Similarly, $G_{i t}^{E \times L(25 \%)}$ is a dummy that takes on the value one if farmer $i$ belongs to the largest $25 \%$ of certified farmers and is certified in an exporter-managed group in year $t$. The variables $G_{i t}^{P \times S(75 \%)}$ and $G_{i t}^{P \times L(25 \%)}$ are defined accordingly for farmers certified in producer-managed groups ${ }^{67}$. We choose a cut-off value of $75 \%$ based on our results that the largest quartile of adopters is significantly different from the first three quartiles in terms of the average size of the certified area and the average net F\&V income (see chapter 4.4.1.). To further explore how sensitive our results are to changes in the chosen cut-off value, we additionally estimate the model using alternative cut-off values of $65 \%$ and $85 \%$.

We expect that farmers with a larger certified area are able to realize higher net income gains than smaller farmers. Larger farmers can exploit scale economies when implementing standard requirements and upgrading their production processes. They sell larger volumes of certified produce and will therefore benefit from positive price effects to a greater extent. Due to their size, they are also likely to have more bargaining power, which may allow them to negotiate higher prices and better conditions. Furthermore, the expected income effects of certification in the different types of certification groups are not unambiguous a priori. On the one hand, farmers certified in exporter-managed groups are expected to experience higher income increases, because exporters cover a substantial share of their adjustment and compliance costs. On the other hand, for precisely that reason, exporters may not pass on higher prices to their suppliers, resulting in smaller expected net income effects for farmers in exporter-managed groups.

These effects are expected to be particularly pronounced in our second scenario, where we take recurrent costs into account. Since in our sample the recurrent costs of compliance were

\footnotetext{
${ }^{67}$ Farmers with a certified area below or equal to 1.6 ha belong to the smallest $75 \%$ of adopters, whereas farmers with a certified area above 1.6 ha belong to the group of the largest $25 \%$ of adopters. The certified area refers to the certified area planted between March 2010 and February 2011. For certified plots that are cultivated multiple times, the certified area is multiplied by the number of harvests.
} 
paid by the development program and by exporters during the first year of standard adoption, we do not have information on the level of recurrent costs for each farmer. Based on the estimates presented earlier, we assume annual fixed recurrent costs of 778 USD for members of farmer-managed certification groups and 109 USD for members of exporter-managed certification groups.

To control for potential self-selection of farmers into GlobalGAP certification and into different types of certification groups, we use a fixed effects estimator that accounts for timeinvariant unobserved heterogeneity across households. Results obtained with a random effects estimator would be biased, if unobservable characteristics that influence the net household income of farmers are correlated with explanatory variables in our model. In particular, the variable GlobalGAP adoption is likely to be endogenous. GlobalGAP is a complex and laborintensive standard that requires large changes in farm management. Therefore, we expect GlobalGAP certification to be influenced by farmer characteristics, such as motivation and ability that also influence net earnings. Similarly, farmers who are risk averse are more likely not to adopt at all or to be certified in exporter-managed groups because the costs of compliance farmers have to incur are lower in these groups than in producer-managed certification groups. Furthermore, risk aversion has also been identified to have a negative influence on income growth (Shaw, 1996, Elbers et al., 2007). These innate personal characteristics are assumed to be constant over time and are captured by the unobserved effect $c_{i}$, which in the fixed effects model is allowed to be correlated with the explanatory variables. The parameter $c_{i}$ includes the effects of all variables, unobservable and observable, that are time-invariant and differ across individuals. Therefore, we cannot include (roughly) timeconstant variables such as education and farm size in the fixed effects model (Wooldridge, 2010).

Time-variant variables that are used as explanatory variables in the three models include the cultivated area with $\mathrm{F} \& \mathrm{~V}$, the cultivated area with other crops, the number of household members working off-farm, the total number of household members, and a dummy variable that equals one if the household is located in a region affected by drought. The northern part of Thailand experienced a severe drought in the beginning of 2010, which led to substantial harvest losses. We do not account for time fixed effects, because the year dummy and the dummy for the drought are closely correlated. As additional controls, we include several variables capturing the share of the area cultivated with different products, separately for the cultivated area with fruit and vegetables and the cultivated area with other crops. 


\subsubsection{Results of the income analysis}

Table 17 presents the results of the fixed effects models estimating farmers' net household income $^{68}$. The first three columns show the estimation results when the recurrent costs of compliance are not accounted for. The latter three columns show the results of the same model specifications, but for the second scenario, i.e., deducting the recurrent costs from net household income.

The first model analyzes the average effect of GlobalGAP certification on farmers' net household income. As expected, we find a large and significantly positive effect of certification, irrespective of whether the recurrent costs of compliance are accounted for or not, indicating that GlobalGAP certification can be highly profitable for Thai fruit and vegetable farmers. On the average, certification has led to an income increase of 10,039 USD, which corresponds to a 90\% rise in net household income for certified farmers. In the second scenario, when we deduct the recurrent costs of compliance from farmers' incomes, the effect is slightly reduced to 9478 USD.

The coefficients of the remaining explanatory variables are as expected. Column (1) in Table 17 shows that farmers affected by the drought experienced a large decrease in net household income of 4873 USD on the average. Farmers who expanded their area cultivated with fruit and vegetables registered an average income increase of 1853 USD per additional hectare. The growing importance of off-farm employment activities that account for an increasing share of rural incomes in Thailand (Rigg and Nattapoolwat, 2001, Rigg, 2005) is also reflected in our data. We find that one additional household member participating in off-farm employment increases household income by 8971 USD on the average. This estimate is comparable to the net income from crop production per full time family worker, which on the average was equal to 8006 USD in 2010.

The results of the second model specification (see column (2) in Table 17) show that the impact of GlobalGAP certification indeed depends on the type of group farmers are certified in. Members of producer-managed certification groups are able to reap significant benefits. On the average, GlobalGAP increased their net income by 14,678 USD during the first year of

\footnotetext{
${ }^{68}$ To test whether the unobserved effect is correlated with the explanatory variables in our models, we employed the Hausman test. In all models, we cannot reject the null hypothesis of zero correlation, and random effects and fixed effects estimates are very similar. However, the existence of unobservable characteristics that are correlated with GlobalGAP certification and/or certification in exporter-managed and producer-managed groups and that also affect net household income is very likely. We therefore decide to use the fixed effects approach, which provides more conservative estimates.
} 
certification. The impact remains highly significant even when the recurrent costs are taken into consideration (see column (4)). In contrast, for farmers certified in exporter-managed groups the impact of certification on net household income is not significant.

These differences can be traced back to the marketing conditions of farmers organized in producer-managed and exporter-managed groups, respectively. Before certification, the majority of farmers certified in producer-managed groups sold to middlemen at the farm gate. As a result of certification, they were able to upgrade their marketing relationships selling to a domestic supermarket in Thailand, which offered high price premiums for GlobalGAP certified produce. In contrast, in the exporter-managed groups marketing relations remained stable and most farmers continued to sell to the exporters, which had supported them in the certification process. Contrary to expectations, they were not able to increase the share of F\&V delivered to high-value markets, and thus continue to sell around $25 \%$ of their produce (mostly off-grade produce) to lower-value domestic markets after certification. In addition, they were also not able to secure price premiums for safety-compliance. In qualitative interviews exporters stated that they do not receive price premiums from importers for GlobalGAP certified produce and that due to their high investments into farm-level upgrading they could not afford rewarding their suppliers with higher prices for certified produce. Thus, for farmers certified in exporter-managed groups, certification rather seems to represent a tool to retain market access, than a strategy to enter new markets and to capture higher incomes.

Finally, columns (3) and (6) in Table 17 present results on heterogeneous impacts among smaller and larger farmers organized in different types of certification groups. While in exporter-managed groups the impact of certification remains insignificant for both larger and smaller farmers, we find that in producer-managed groups the impact of GlobalGAP indeed varies with land size. The impact on farmers' net household income is positive and significant for all farmers as long as the recurrent costs of compliance are not taken into account. Yet, the magnitude of the effect is with 37,732 USD more than eight times larger for the largest $25 \%$ of certified farmers than for the smallest $75 \%$ of certified farmers, who on average gain 4465 USD from certification. Accordingly, when the recurrent costs of compliance are taken into account, the coefficient measuring the impact of GlobalGAP becomes insignificant for the smallest $75 \%$ of certified farmers in producer-managed groups (see column (6) in Table 17). This provides some indication that certification may not be profitable for small-scale farmers in the long run, if they have to bear the recurrent costs of compliance. 
To further investigate the sensitivity of our results to the choice of the cut-off value of $75 \%$, we estimate additional models using alternative thresholds of $65 \%$ and $85 \%$ (results are reported in the appendix). Results show that when choosing a cut-off value of $65 \%$, the impact of GlobalGAP certification is insignificant for the smallest $65 \%$ of famers organized in producer-managed groups, even if recurrent costs of compliance are not taken into account. In contrast, if the higher cut-off value of $85 \%$ is chosen, the impact of GlobalGAP certification is positive and significant for smaller and larger farmers in producer-managed certification groups under both scenarios, i.e., regardless of whether the recurrent costs are taken into account. Thus, our results indicate that certification in producer-managed groups leads to significant income effects but only beyond a certain size threshold. In our sample, more than half of the GlobalGAP adopters cultivate a certified area of less than one hectare, which according to our analysis is too small to generate significant returns from GlobalGAP certification. This is particularly so, if the recurrent costs of compliance have to be borne by farmers. 
Table 17: Impact of certification on net household income (USD)

\begin{tabular}{|c|c|c|c|c|c|c|}
\hline & \multicolumn{3}{|c|}{$\begin{array}{c}\text { Scenario 1: } \\
\text { Net household income }\end{array}$} & \multicolumn{3}{|c|}{$\begin{array}{c}\text { Scenario 2: } \\
\text { Net household income } \\
\text { - recurrent costs }\end{array}$} \\
\hline & $(1)$ & (2) & (3) & (4) & (5) & (6) \\
\hline GlobalGAP $(0 / 1)^{\mathrm{a}}$ & $\begin{array}{c}10,039 * * * \\
(3800)\end{array}$ & 2 & - & $\begin{array}{c}9478^{* * *} \\
(3791)\end{array}$ & - & - \\
\hline $\begin{array}{l}\text { GlobalGAP } \\
\text { (exporter group) }(0 / 1)^{\mathrm{a}}\end{array}$ & - & $\begin{array}{c}373 \\
(5071)\end{array}$ & - & - & $\begin{array}{c}264 \\
(5071)\end{array}$ & - \\
\hline $\begin{array}{l}\text { GlobalGAP } \\
\text { (producer group) }(0 / 1)^{\mathrm{a}}\end{array}$ & - & $\begin{array}{c}14,678^{* * *} \\
(5247)\end{array}$ & - & - & $\begin{array}{l}13,900 * * * \\
(5247)\end{array}$ & - \\
\hline $\begin{array}{l}\text { GlobalGAP (smallest } 75 \% \text { in } \\
\text { exporter group }(0 / 1)^{\text {ab }}\end{array}$ & - & 5 & $\begin{array}{l}-3963 \\
(5460)\end{array}$ & - & 5. & $\begin{array}{l}-4072 \\
(5460)\end{array}$ \\
\hline $\begin{array}{l}\text { GlobalGAP (largest } 25 \% \text { in } \\
\text { exporter group }(0 / 1)^{\mathrm{ac}}\end{array}$ & - & - & $\begin{array}{c}16,451 \\
(12,176)\end{array}$ & - & - & $\begin{array}{c}16,342 \\
(12,176)\end{array}$ \\
\hline $\begin{array}{l}\text { GlobalGAP (smallest } 75 \% \text { in } \\
\text { farmer group }(0 / 1)^{\text {b }}\end{array}$ & - & - & $\begin{array}{l}4465^{*} \\
(2732)\end{array}$ & - & - & $\begin{array}{c}3687 \\
(2732)\end{array}$ \\
\hline $\begin{array}{l}\text { GlobalGAP (largest } 25 \% \text { in } \\
\text { farmer group }(0 / 1)^{\text {ac }}\end{array}$ & - & - & $\begin{array}{c}37,732 * * * \\
(13,135)\end{array}$ & - & - & $\begin{array}{c}36,954 * * * \\
(13,135)\end{array}$ \\
\hline Cultivated area F\&V (ha) & $\begin{array}{c}1853^{* * *} \\
(735)\end{array}$ & $\begin{array}{c}1833^{* * *} \\
(730)\end{array}$ & $\begin{array}{c}1948 * * * \\
(694)\end{array}$ & $\begin{array}{c}1852 * * * \\
(734)\end{array}$ & $\begin{array}{c}1833^{* * *} \\
(730)\end{array}$ & $\begin{array}{c}1948^{* * *} \\
(694)\end{array}$ \\
\hline $\begin{array}{l}\text { Cultivated area other } \\
\text { products (ha) }\end{array}$ & $\begin{array}{l}1346 \\
(983)\end{array}$ & $\begin{array}{l}1392 \\
(993)\end{array}$ & $\begin{array}{l}1412 \\
(998)\end{array}$ & $\begin{array}{l}1348 \\
(983)\end{array}$ & $\begin{array}{l}1392 \\
(993)\end{array}$ & $\begin{array}{l}1412 \\
(998)\end{array}$ \\
\hline $\begin{array}{l}\text { No. household members off- } \\
\text { farm }\end{array}$ & $\begin{array}{l}8971 * * \\
(4337)\end{array}$ & $\begin{array}{l}9135 * * \\
(4370)\end{array}$ & $\begin{array}{l}9646^{* *} \\
(4447)\end{array}$ & $\begin{array}{l}8979 * * \\
(4337)\end{array}$ & $\begin{array}{l}9135 * * \\
(4370)\end{array}$ & $\begin{array}{l}9646 * * \\
(4447)\end{array}$ \\
\hline No. of household members & $\begin{array}{l}-1086 \\
(1757)\end{array}$ & $\begin{array}{l}-1135 \\
(1762)\end{array}$ & $\begin{array}{l}-1052 \\
(1760)\end{array}$ & $\begin{array}{l}-1088^{*} \\
(1757)\end{array}$ & $\begin{array}{l}-1135 \\
(1762)\end{array}$ & $\begin{array}{l}-1052 \\
(1760)\end{array}$ \\
\hline Drought (0/1) & $\begin{array}{l}-4873^{*} \\
(2550)\end{array}$ & $\begin{array}{c}-5645^{* *} \\
(2761)\end{array}$ & $\begin{array}{l}-4939 * \\
(2649)\end{array}$ & $\begin{array}{l}-4909 \\
(2551)\end{array}$ & $\begin{array}{c}-5645^{* *} \\
(2761)\end{array}$ & $\begin{array}{l}-4939^{*} \\
(2649)\end{array}$ \\
\hline Constant & $\begin{array}{c}20,675 \\
(35,083)\end{array}$ & $\begin{array}{c}19,275 \\
(35,472) \\
\end{array}$ & $\begin{array}{c}18,272 \\
(35,284)\end{array}$ & $\begin{array}{c}20,609 \\
(35,082)\end{array}$ & $\begin{array}{c}19,275 \\
(35,193)\end{array}$ & $\begin{array}{c}18,272 \\
(35,284)\end{array}$ \\
\hline Number of observations & 428 & 428 & 428 & 428 & 428 & 428 \\
\hline R-squared & 0.16 & 0.16 & 0.16 & 0.16 & 0.16 & 0.16 \\
\hline
\end{tabular}

Notes: Statistical significance at the $1 \%(* * *), 5 \%(* *)$, and $10 \%(*)$ levels. Coefficient estimates are shown with cluster robust standard errors in parentheses. Variables capturing the share of area cultivated with different products are included but not shown due to space restrictions. The full model results are shown in Appendix III.

${ }^{a}$ The reference group is non-certified farmers.

${ }^{\mathrm{b}}$ Certified area ranges from 0.16 to $1.6 \mathrm{ha}$.

${ }^{\mathrm{c}}$ Certified area ranges from 1.92 to 33.92 ha.

Source: Own data

\subsection{Determinants of continued compliance with GlobalGAP}

During the adoption process farmers had access to support from a development program that covered the major part of non-recurrent and recurrent costs of compliance and also provided training and technical assistance. The program ended soon after farmers obtained certification for the first time in mid 2010. Hence, farmers had no donor support when they had to decide on the renewal of their certification one year after initial adoption.

Of the 214 farmers in our sample, 72 successfully adopted the GlobalGAP standard in 2010. One year later, only 18 farmers succeeded to renew their certificate, while 54 farmers 
abandoned the standard. Since the decision to become re-certified is conditional on having adopted the GlobalGAP standard in the previous year, we jointly analyze the determinants of initial adoption and continued compliance with the GlobalGAP standard. Both decisions depend on farmers' expected costs and benefits of certification as well as on their capabilities to achieve certification (Henson et al., 2011).

\subsubsection{Econometric approach to analyze GlobalGAP adoption and continued compliance}

We use a bivariate probit model with sample selection for our analysis of the determinants of adoption and continued compliance with the GlobalGAP standard. This model provides a framework for analyzing two subsequent binary decisions with correlated error terms, when the outcome of the second decision is contingent on the outcome of the first decision (Neill and Lee, 2001). In our analysis the decision to become re-certified in 2011 is conditional on having adopted the GlobalGAP standard in 2010. Therefore, in a first model, we estimate the farmers' probability to adopt the GlobalGAP standard in 2010, and in a second model that only includes the subsample of initial adopters, we estimate the probability to obtain a renewal of the certification in 2011. Both decisions are likely to be influenced by the same unobservable variables, and hence, we expect the error terms of the two equations to be correlated.

For the analysis of initial GlobalGAP adoption data from our baseline survey in 2010 is used, which corresponds to the time period before GlobalGAP certification for the adopters in our sample. For the analysis of continued compliance, we use data from the follow-up survey, which was collected in 2011 shortly before adopters decided whether or not to apply for recertification. Exporters and farmer groups provided us with information on which farmers obtained a renewal of their certificate after our survey ended. None of the interviewed households that were classified as "non-adopters" in the baseline survey received a GlobalGAP certificate or were in the adoption process by 2011. 
The bivariate probit model, adapted from Greene (2008), can be specified as follows.

$$
\begin{gathered}
\text { (1) } y_{i t 1}^{*}=\boldsymbol{\beta}_{1}^{\prime} \boldsymbol{x}_{i t 1}+\epsilon_{i t 1} y_{i t 1}=1 \text { if } y_{i t 1}^{*}>0, y_{i t 1}=0 \text { if } y_{i t 1}^{*}<0 \\
\text { (2) } y_{i t 2}^{*}=\boldsymbol{\beta}_{2}^{\prime} \boldsymbol{x}_{i t 2}+\epsilon_{i t 2}, y_{i t 2}=1 \text { if } y_{i t 2}^{*}>0, y_{i t 2}=0 \text { if } y_{i t 2}^{*}<0 \\
\epsilon_{i t 1}, \epsilon_{i t 2} \sim \operatorname{BVN}(0,0,1,1, \rho), \operatorname{Var}\left[\epsilon_{i t 1}\right]=\operatorname{Var}\left[\epsilon_{i t 2}\right]=1, \\
\operatorname{Cov}\left[\epsilon_{i t 1}, \epsilon_{i t 2}\right]=\rho
\end{gathered}
$$$$
\left(y_{i t 2}, \boldsymbol{x}_{i t 2} \text { is observed only when } y_{i t 1}=1\right) \text {, }
$$

where the $\beta^{\prime} s$ are parameter vectors to be estimated, $\boldsymbol{x}_{i t 1}$ and $\boldsymbol{x}_{i t 2}$ are vectors of observed variables explaining the adoption decision in $t 1$ (year 2010) and continued compliance decision in $t 2$ (year 2011), and $\epsilon_{i t 1}$ and $\epsilon_{i t 2}$ are disturbance terms. The $y_{i t}^{*} s$ are latent variables which represent the utility a farmer receives from (1) adopting GlobalGAP in 2010 and (2) continuing to comply with GlobalGAP in 2011. We assume that if $y_{i t}^{*}>0$, the observed choice will be GlobalGAP adoption or continued compliance $\left(y_{i t}=1\right)$, and if $y_{i t}^{*}<0$, a farmer will chose not to adopt or to abandon $\left(y_{i t}=0\right)$. It is important to note that $y_{i t 2}$ is only observed if $y_{i t 1}=1$. The error terms are assumed to follow a bivariate normal distribution with zero mean, unit variance and correlation $\rho$. Conveniently, the likelihood ratio test on the significance of $\rho$ also provides a test for the existence of selection bias. If we cannot reject the null hypothesis that $\rho=0$, the correlation between the error terms of the two equations is not statistically significant, thus allowing us to estimate two separate univariate probit models (Greene, 2008).

Table 18 describes the explanatory variables included in the bivariate probit model. Most of the factors are expected to influence both the adoption decision in 2010 and the recertification decision in 2011. They can be roughly divided into three broad categories: factors related to the support households receive, factors that influence farmers' ability to finance the costs of compliance, and household characteristics that determine the capability of households to comply with GlobalGAP requirements. 


\section{Table 18: Variable definition}

\begin{tabular}{|c|c|c|}
\hline Variables & Definition & Decisions \\
\hline Exporter support & $\begin{array}{l}\text { Dummy = } 1 \text { if the farmer received support from an exporter } \\
\text { (technical assistance, financial support, QMS management) }\end{array}$ & $\begin{array}{l}\text { Adoption, } \\
\text { Re-certification }\end{array}$ \\
\hline Donor support & $\begin{array}{l}\text { Dummy }=1 \text { if the farmer received support from a donor to } \\
\text { manage the QMS }\end{array}$ & Adoption \\
\hline Number extension topics & $\begin{array}{l}\text { Number of topics on which the farmer received technical advice } \\
\text { and extension }^{\mathrm{a}}\end{array}$ & $\begin{array}{l}\text { Adoption, } \\
\text { Re-certification }\end{array}$ \\
\hline Age of the household head & Age of the household head (years) & $\begin{array}{l}\text { Adoption, } \\
\text { Re-certification }\end{array}$ \\
\hline $\begin{array}{l}\text { Number of household } \\
\text { members }\end{array}$ & Number of household members & $\begin{array}{l}\text { Adoption, } \\
\text { Re-certification }\end{array}$ \\
\hline College graduate & $\begin{array}{l}\text { Dummy }=1 \text { if at least one household member graduated from } \\
\text { college }\end{array}$ & $\begin{array}{l}\text { Adoption, } \\
\text { Re-certification }\end{array}$ \\
\hline $\begin{array}{l}\text { Change in net household } \\
\text { income (1000 USD) }\end{array}$ & $\begin{array}{l}\text { Change in net household income from } 2009 \text { to } 2010 \text { (in } 1000 \\
\text { USD) }\end{array}$ & Re-certification \\
\hline Farm size (ha) & Farm size (in ha) & $\begin{array}{l}\text { Adoption, } \\
\text { Re-certification }\end{array}$ \\
\hline $\begin{array}{l}\text { Share of total land } \\
\text { certified }\end{array}$ & Share of total land that is GlobalGAP certified & Re-certification \\
\hline $\begin{array}{l}\text { Share of cultivated area } \\
\text { under F\&V }\end{array}$ & Share of cultivated area under fruit and vegetables & Adoption \\
\hline $\begin{array}{l}\text { Share F\&V area with } \\
\text { sprinkler or drip irrigation }\end{array}$ & $\begin{array}{l}\text { Share of area under fruit and vegetables that is irrigated with } \\
\text { sprinkler or drip irrigation systems }\end{array}$ & Adoption \\
\hline Q-GAP certified & Dummy = 1 if farm is Q-GAP certified & Adoption \\
\hline
\end{tabular}

${ }^{\mathrm{a}}$ This includes advice and extension offered by donors.

Source: own illustration

The support that households receive varies greatly between the different certification models implemented by the development program. If farmers are certified in producer-managed groups they have at best assistance from the donor in running the QMS. However, this support ceases with the withdrawal of the development project. If farmers can count on the support of an exporter, this support is more likely to be available in the long run and thus relevant for the re-certification decision as well. Thus, in the adoption model, we include a dummy that equals one if the farmer received support from the donor in running the QMS, and another dummy that equals one if the farmer is supported by an exporter. The latter variable is also included in the re-certification model. External support by either the donor or the exporter is expected to be critical to help farmers overcome the barriers to initial adoption. Regarding the recertification decision, we expect that farmers who are linked to an exporter are more likely to renew their certificate than farmers in producer-managed groups who lack external support after the withdrawal of donors. On the other hand, our previous analysis showed that certification of farmers in exporter-managed groups did not result in significant income increases, which may lower their incentives to get re-certified. Finally, we include a variable on the number of topics that farmers have received extension on to capture their general 
access to support and information that may also be relevant for the adoption and recertification decisions.

Regarding the factors that influence farmers' ability to finance the costs of compliance, we include different variables related to land size. Since the costs of compliance are to a large extent fixed costs, we expect larger farmers who can exploit scale economies to be more likely to adopt and continue to comply with GlobalGAP. In addition, farm size is often considered a proxy for household wealth and access to credit, which would also improve farmers' ability to finance investments.

Finally, household characteristics that determine the capability of households to comply with GlobalGAP requirements, such as age, education, and access to family labor, are included in both the adoption and the re-certification model. In particular, the availability of family labor is expected to have a positive influence not only on initial adoption but also on continued compliance, because standard-related tasks, such as record keeping and integrated pest management, require constantly high levels of labor input. Similarly, the educational level of farmers is critical for the adoption of knowledge-intensive practices that need to be implemented to achieve certification. And in fact, education is likely to be even more relevant for the re-certification decision after donor support is withdrawn and farmers have to manage tasks like the QMS in the absence of external support.

Furthermore, there are some factors like the availability of an efficient irrigation system and previous experience with food safety-related certification schemes that are likely to influence only the initial adoption decision. Therefore, in the adoption model, we include a variable on the share of the area with $F \& V$ that is irrigated with sprinkler and drip irrigation ${ }^{69}$. Given that the implementation of the most efficient irrigation system is a requirement of GlobalGAP, farmers already using these advanced technologies are likely to have a competitive advantage in achieving initial certification. However, after initial certification, all farmers should have installed such irrigation systems on their plots, and therefore, we do not include this variable in the re-certification model. Similarly, we include a dummy variable that equals one if the farmer has been previously awarded the Thai public standard for good agricultural practices (Q-GAP) in the adoption model. The experience gained during the implementation of the QGAP standard is expected to positively influence farmers’ likelihood to achieve GlobalGAP

\footnotetext{
${ }^{69}$ The GlobalGAP Smallholder Guide for the Soil and Water Module (FoodPLUS, 2010b) identifies sprinkler and drip irrigation as the most efficient irrigation systems.
} 
certification. However, given that Q-GAP is a basic minimum standard that can be easily obtained and that does not specify stringent requirements (Sardsud, 2007), these positive effects are not likely to last beyond initial certification with GlobalGAP.

As regards continued compliance, this decision is likely to fundamentally depend on farmers' experience with certification during the first year. Farmers who experienced no or only a very small increase in their income as a result of certification are likely to have less incentive and motivation to renew their certification in the next year. To capture this we include a variable on the change in household income between 2009 and 2010 in the re-certification model.

\subsubsection{Probit model results}

Table 19 presents the results of the bivariate probit model analyzing the determinants of GlobalGAP adoption in 2010 and of continued compliance with GlobalGAP in 2011. The results reveal that the error terms of the two equations on GlobalGAP adoption and recertification are not significantly correlated, i.e., we cannot reject the null hypothesis that $\rho=0$. Therefore, the marginal effects for the re-certification decision presented in Table 19 are calculated based on univariate probit estimates.

With respect to the initial adoption decision our findings largely confirm our expectations and the results of previous studies on the adoption of the GlobalGAP standard. We find that external support is crucial for farmers to overcome the barriers to initial GlobalGAP adoption. Farmers who are supported by an exporter or a donor in the management of the QMS and farmers with better access to extension services are more likely to become certified. Moreover, the educational attainment of the household, the availability of sprinkler and drip irrigation systems, and experience with the Q-GAP certificate have a positive influence on standard adoption, indicating that more progressive farmers and farmers who are better prepared for the implementation of GlobalGAP have an advantage in the adoption process. Contrary to our expectations, we do not find a significant impact of farm size on the probability to adopt, and the share of cultivated area under fruit and vegetables is negatively associated with certification. This indicates that smaller farmers are not systematically excluded from certification in 2010 and partly reflects the aim of the development program to target small-scale and resource-poor farmers to help them overcome the barriers to standard adoption. 
In fact, we find that with respect to the re-certification decision, external support is still the most critical factor. Support from an exporter increases the probability to become re-certified by 85 percentage points. This finding confirms that farmers depend on external support not only to overcome the initial barriers to standard adoption, but also to continuously comply with the GlobalGAP standard. We further find that for the re-certification decision scale economies play an important role. Although smaller farmers were not systematically excluded from the initial certification decision, we find that larger farmers are more likely to renew their certificate after donor support ends. Our results show that a one hectare increase in farm size and a $10 \%$ increase in the share of land that is initially certified raise the probability to become re-certified by three and five percentage points, respectively.

In contrast to our expectations, the change in net household income from 2009 to 2010 is not significant. This indicates that the net monetary benefits derived from certification are not the most decisive factor for the renewal of the certification. In fact, even if farmers derive significant benefits, as was the case for certified farmers organized in producer-managed groups in our sample, they may not succeed to renew their certificate in the absence of donor support. As the results of the income analysis revealed, it was predominantly the largest quartile of adopters who were able to achieve significant income increases. Our model may thus suffer from multicollinearity if we include both the farm size and the change in income. When we exclude farm size-related variables from the re-certification equation, the coefficient on the change in net household income turns significant (see Appendix IV). However, the effect is rather small: a rise in the income change of 1000 USD increases the likelihood of re-certification by 0.5 percentage points.

As opposed to the initial certification decision, education is no longer significant in the recertification equation. While a high level of education may still be advantageous to achieve continued compliance with the GlobalGAP standard, it is indeed the case that the least educated farmers drop out already at the initial adoption stage. Therefore, when we estimate the influence of education on re-certification conditional on initial certification in 2010, the variation in educational achievement in the sample is greatly reduced.

Our results provide important insights into the sustainability of development programs that support small-scale farmers to achieve GlobalGAP certification. We find evidence that donor support enables small-scale farmers to overcome the barriers to standard adoption, but that these farmers are often not able to renew their certificate after the withdrawal of the 
development program. This confirms Graffham, Karehu et al. (2007), who claim that donor support may facilitate certification that is not sustainable in the long run, because farmers lack the capacity to bear recurrent costs after donor support ends. In our sample, it is those farmers who can count on continuous support from downstream actors of the value chain, who are most likely to achieve a renewal of their certificate. To achieve sustainability of donorassisted standard adoption, it is therefore of paramount importance to pay sufficient attention to value chain linkages and business models that provide long-term support to smallholder farmers.

Table 19: Bivariate probit model estimating GlobalGAP adoption in 2010 and continued compliance in 2011

\begin{tabular}{|c|c|c|c|}
\hline \multirow[b]{3}{*}{ Explanatory variables } & \multirow{2}{*}{$\begin{array}{c}\begin{array}{c}\text { Adoption } \\
(2010)\end{array} \\
\mathrm{N}=214 \\
\end{array}$} & \multirow{2}{*}{\multicolumn{2}{|c|}{$\begin{array}{c}\text { Re-certification } \\
\text { (2011) }\end{array}$}} \\
\hline & & & \\
\hline & Coefficient & Coefficient & Marginal effects \\
\hline Exporter support $(0 / 1)^{\mathrm{a}}$ & $\begin{array}{c}2.01^{* * *} \\
(0.39)\end{array}$ & $\begin{array}{c}3.46^{* * *} \\
(0.80)\end{array}$ & $\begin{array}{c}0.85^{* * *} \\
(0.11)\end{array}$ \\
\hline Donor support $(0 / 1)^{\mathrm{a}}$ & $\begin{array}{c}1.59^{* * *} \\
(0.41)\end{array}$ & $\begin{array}{c}0.08 \\
(0.09)\end{array}$ & 5 \\
\hline Number extension topics & $\begin{array}{c}0.17 * * * \\
(0.05)\end{array}$ & $\begin{array}{c}0.02 \\
(0.02)\end{array}$ & $\begin{array}{c}0.02 \\
(0.02)\end{array}$ \\
\hline Age of the household head & $\begin{array}{c}-0.05^{* * *} \\
(0.02)\end{array}$ & $\begin{array}{l}-0.11 \\
(0.12)\end{array}$ & $\begin{array}{c}0.00 \\
(0.00)\end{array}$ \\
\hline Number of household members & $\begin{array}{c}0.11 \\
(0.09)\end{array}$ & $\begin{array}{c}0.69 \\
(0.49)\end{array}$ & $\begin{array}{c}-0.02 \\
(0.02)\end{array}$ \\
\hline College graduate $(0 / 1)$ & $\begin{array}{c}1.17 * * * \\
(0.30)\end{array}$ & $\begin{array}{c}0.08 \\
(0.09)\end{array}$ & $\begin{array}{c}0.16 \\
(0.10)\end{array}$ \\
\hline Change in net household income (1000 USD) & - & $\begin{array}{c}0.01 \\
(0.01)\end{array}$ & $\begin{array}{c}0.00 \\
(0.00)\end{array}$ \\
\hline Farm size (ha) & $\begin{array}{l}-0.08 \\
(0.06)\end{array}$ & $\begin{array}{c}0.15 \\
(0.10)\end{array}$ & $\begin{array}{l}0.03^{*} \\
(0.02)\end{array}$ \\
\hline Share of total land certified & - & $\begin{array}{c}2.67 * * * \\
(1.01)\end{array}$ & $\begin{array}{c}0.46^{* * *} \\
(0.15)\end{array}$ \\
\hline Share of cultivated area under F\&V & $\begin{array}{c}-1.32 * * \\
(0.58)\end{array}$ & 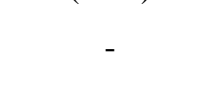 & 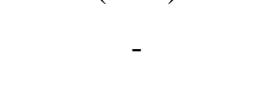 \\
\hline Share F\&V area with sprinkler/drip irrigation & $\begin{array}{c}1.19 * * * \\
(0.40)\end{array}$ & - & - \\
\hline $\begin{array}{l}\text { Q-GAP } \\
\text { certified (0/1) }\end{array}$ & $\begin{array}{c}0.73^{* * *} \\
(0.29)\end{array}$ & - & - \\
\hline Constant & $\begin{array}{l}-1.51 \\
(1.03) \\
\end{array}$ & $\begin{array}{c}-5.05^{* * *} \\
(1.58) \\
\end{array}$ & - \\
\hline Correlation rho & & $-0.34(0.49)$ & \\
\hline Log pseudo-likelihood & & -141.0583 & \\
\hline Wald chi2 & & 30.11 & \\
\hline Prob > chi2 & & 0.00 & \\
\hline
\end{tabular}

Notes: Statistical significance at the $1 \%\left({ }^{* * *}\right), 5 \%\left({ }^{* *}\right)$ and $10 \%(*)$ levels. Robust standard errors are shown in parentheses. The marginal effects are calculated at the means of the variables. For dummy variables, the marginal effect is calculated for a discrete change from 0 to 1.

${ }^{\mathrm{a}}$ The reference group is farmers that did not receive support to manage the QMS.

Source: Own data 


\subsection{Conclusions}

In this study, we evaluate the impact of GlobalGAP certification on farmers' net household income and analyze the factors influencing continued compliance with GlobalGAP. We extend the existing literature on the implications of private food safety and quality standards for small-scale farmers in several ways. First of all, in addition to estimating average treatment effects of certification on net household income, we also look at subgroup-specific mean treatment effects of GlobalGAP adoption. Moreover, while previous studies have relied on cross-sectional data sets, we use a unique panel data set of Thai fruit and vegetable farmers that allows us to control for non-random selection into GlobalGAP certification that is based on unobservable time-invariant characteristics. Finally, to the best of our knowledge this is the first empirical study that analyzes the factors influencing GlobalGAP re-certification after the withdrawal of donor programs.

Our results show that on the average GlobalGAP certification has a highly positive and significant impact on farmers' net household incomes. However, the large average effect conceals the existence of considerable heterogeneity among subgroups of adopters. While GlobalGAP certification in producer-managed groups positively influences net household incomes, certification in exporter-managed groups does not result in significant income effects. However, we are only looking at short-term effects and in the long run members of exporter-managed groups might also realize significant income increases. For example, if GlobalGAP certified produce is in high demand, farmers may increase their incomes by extending the area cultivated with certified crops and by selling higher volumes. If we further explore heterogeneous effects between larger and smaller certified farmers, it becomes evident that the positive impact of certification in producer-managed groups is subject to size effects. GlobalGAP certification has a large positive and significant effect on the household income of the largest quartile of adopters, while the smallest $75 \%$ of adopters only benefit from certification, if recurrent costs do not have to be paid by farmers. During the first year of certification, the recurrent costs of compliance are often covered by donor programs that support the GlobalGAP certification of smallholder farmers, which was also true in our research area. After the withdrawal of donors, however, farmers will have to incur the full amount of recurrent costs, as long as they are not supported by an exporter or other downstream actor of the value chain. Since the recurrent costs are to a large extent fixed costs, they can add up to a significant share of farmers' total net F\&V income, and thus represent a particular challenge for small-scale farmers. 
Consistence with these results the estimates of the bivariate probit model show that, in the absence of donor support, GlobalGAP re-certification is significantly influenced by farm size and the share of total land that is certified. This indicates that larger farmers are able to realize economies of scale and thus have fewer difficulties in financing the recurrent costs of compliance. Yet, in contrast to our expectations based on results of the income analysis, it is not the farmers in producer-managed certification groups, but those organized in exportermanaged groups who are more likely to become re-certified. The support by an exporter is critical and increases the probability to obtain a renewal of the GlobalGAP certificate by 85 percentage points. This finding indicates that compliance with GlobalGAP remains challenging after initial adoption, and that small-scale farmers are usually not able to become re-certified if they do not have access to external support.

Based on these results, we conclude that public-private partnerships between donors and exporters that support the certification of small-scale farmers in exporter outgrower schemes offer the opportunity to make donor supported GlobalGAP adoption sustainable. Moreover, the initial support of a relatively low number of farmers in exporter-managed groups could result in a larger number of certified farmers when exporters extend their certification groups, following an initial trial period where only a small share of suppliers is certified. However, certification of farmers in exporter-managed groups is also likely to be unsustainable if exporters do not benefit from certification, or if supported exporters are too small to offer substantial support to farmers and do not have well qualified outgrower management teams that continuously monitor and support the compliance of farmers with the GlobalGAP standard (Graffham et al., 2007b).

Moreover, our analyses show that not only GlobalGAP adoption but also continued compliance with the standard is challenging for small-scale farmers. Our results also mirror the overall development in Thailand, where the number of certified producers decreased from 923 in 2009 to 263 in 2011 (FoodPLUS, 2011a, FoodPLUS, 2009b). To date, the number of GlobalGAP certified producers in developing countries is still low and in 2011 only 4\% of GlobalGAP certified producers were based in Africa and 9\% in Asia. This suggests that GlobalGAP certification is not a viable option for the majority of small-scale farmers in developing countries in the near future. Moreover, only a small share of farmers in developing countries is involved in the high-value horticultural export sector, where the GlobalGAP standard is a requirement, while the majority serves domestic markets or lower value export markets. In these markets, opportunities for product differentiation equally exist while 
standard requirements are much lower (Jaffee et al., 2011). Therefore, by supporting the implementation of lower level food safety and quality standards that are more adapted to the situation of small-scale farmers developing countries, and by investing into extension services and training programs that aim to disseminate the widespread use of good agricultural practices, donor programs are more likely to achieve positive long term impacts on rural development and poverty reduction. 


\section{Conclusion}

\subsection{Summary of findings}

Increased participation of small-scale farmers in the growing market for high-value agricultural products can contribute to alleviate poverty in developing countries. In particular, several studies have shown that small-scale farmers have a comparative advantage in the production of fruit and vegetables, and that diversification into horticulture can increase rural incomes and employment levels. However, the market access of smallholders to high-value supply chains is increasingly threatened by a tightening and proliferation of public and private food safety and quality standards. While public standards have long been recognized as an important barrier to exports from developing to developed countries, private standards, although voluntary, are becoming a requirement to access high-value markets worldwide. The GlobalGAP standard, which we focused on in this study, is the most widely implemented private pre-farm gate standard today.

This study aimed to contribute to the growing literature on the implications of private food safety and quality standards for small-scale farmers in developing countries. Previous studies have shown that compliance with GlobalGAP is especially challenging for small-scale farmers due to the high costs of compliance and the high technical and managerial requirements of the standard. However, certification with GlobalGAP is also discussed to lead to higher and more stable incomes, and thus to a reduction of poverty and vulnerability. Therefore, the main aim of this study was to identify mechanisms that enable small-scale farmers to sustainably adopt the GlobalGAP standard and to benefit from certification. More specifically, three research objectives were addressed. First, we identified the factors that influence GlobalGAP adoption. Second, we assessed the average and subgroup-specific mean impacts of the GlobalGAP standard on producer prices and on farmers' net household income and third, we analyzed the determinants of continued compliance with GlobalGAP following the withdrawal of donor support.

Based on a cross-sectional data set of Thai fruit and vegetable farmers collected in 2010, we compare different institutional arrangements that can be formed under GlobalGAP group certification and identify the factors influencing GlobalGAP adoption. We contribute to the existing literature by for the first time taking the role of support by donors and exporters in the compliance process into account. In our research area, the increasing demand for GlobalGAP certified produce encouraged the formation of new institutional arrangements between donors, 
exporters and farmers to facilitate GlobalGAP adoption by smallholders. Farmers participating in a development program were organized in certification groups with either a donor-managed, farmer-managed or exporter-managed QMS. Results of a probit model estimating the factors influencing GlobalGAP adoption show that the support by donors and exporters is crucial to enable small-scale farmers with limited human, social and physical capital to adopt the GlobalGAP standard. In the groups with a donor-managed QMS, almost all responsibility for GlobalGAP implementation was taken over by the donor and we find that a donor-managed QMS increases the probability to adopt by 88 percentage points. In the exporter-managed groups, the QMS management was taken over by the companies, and farmers received financial, technical and managerial support during the implementation process, leading to a 48 percentage points higher probability of farmers in these groups to adopt the standard. In addition, we find that the educational attainment of households, household wealth, the availability of family labor, the use of efficient irrigation systems and previous involvement in high-value supply chains are important factors influencing the likelihood to adopt the GlobalGAP standard.

Furthermore, to assess whether farmers benefit from GlobalGAP adoption, we analyze the impacts of GlobalGAP certification on producer prices and farmers' net household income. Previous studies have analyzed average treatment effects of GlobalGAP certification which, however, may conceal important heterogeneous effects of certification across subgroups of adopters. We hypothesize that the effects of certification differ depending on whether farmers are certified in exporter-managed or producer-managed groups. Moreover, while previous studies rely on cross-sectional data sets, this study is based on a unique panel data set of 218 Thai fruit and vegetable farmers. The availability of panel data allows us to estimate a fixed effects model to control for time-invariant unobserved heterogeneity across households. Our results show that certification can be highly profitable for small-scale farmers. On the average GlobalGAP certification results in 43\% higher prices and 10,039 USD higher net household incomes. However, the high average effect is driven by large significant impacts in the producer-managed groups. Farmers certified in producer-managed groups increased the share of produce sold to high-value markets following GlobalGAP adoption, and certification resulted in 68\% higher prices and 14,678 USD higher net household incomes. In contrast, we cannot identify a significant impact of certification on prices and net household income for farmers certified in exporter-managed groups. Farmers organized in exporter-managed certification groups sold to the contracting exporter as the main buyer before and after certification and did not gain access to new markets. Moreover, exporters did not pay 
premium prices for certified produce due to the high costs of supporting farmers in the compliance process with GlobalGAP. However, our analysis represents short term impacts of certification and in the long run farmers in exporter-managed groups may also benefit from certification. GlobalGAP implementation is associated with knowledge gains and improved farming practices which may lead to higher product quality and thus indirectly to higher prices. Moreover, farmers may benefit from more stable and higher demand for their products in the long run.

The analysis of income effects described above does not take the annually recurring costs of compliance into account (e.g., the costs for operating the QMS, laboratory analyses, trainings and certification fees) because these were paid by the development program and by exporters during the first year of compliance. However, these costs are relevant for the decision to become re-certified and following the withdrawal of donor support, farmers and exporters have to incur the recurrent costs of compliance on their own. Deducting the recurrent costs of compliance from $\mathrm{F} \& \mathrm{~V}$ revenues, we find that the impact of GlobalGAP certification on farmers' net household income is only positive and significant for larger farmers certified in producer-managed groups. Similar to the investment costs associated with GlobalGAP adoption, the recurrent costs of compliance are to a large extent fixed costs and thus disadvantage small-scale farmers.

The results of the income analysis raise the question whether certification will be sustainable in the long run. The decision to become re-certified depends on the expected costs and benefits of continued compliance with GlobalGAP and on a farmer's capabilities. In exportermanaged certification groups, the companies offer continuous support to farmers to enable them to comply with GlobalGAP in the long run, but we find that certification does not have a significantly positive impact on the net household income of farmers certified in exportermanaged groups. In contrast, in the producer-managed certification groups external support is no longer available after the end of the development program, but we identify a positive effect of certification on net household income, which may positively influence farmers' decision to become re-certified.

Consistent with our findings of the income analysis, the results of the probit model estimating continued compliance with GlobalGAP show that GlobalGAP re-certification is influenced by farm size and the share of area that is certified. This indicates that larger farms can realize economies of scale and have fewer difficulties in financing the recurrent costs of compliance. However, it is not the farmers in producer-managed certification groups but those in exporter- 
managed certification groups who are more likely to continue to comply with GlobalGAP. Support by an exporter increases the probability to become re-certified by 85 percentage points and is thus the most important factor explaining the sustainability of GlobalGAP adoption. Our findings indicate that complying with GlobalGAP remains challenging after initial adoption and that resource-poor small-scale farmer need to rely on external support to be able to continually comply with GlobalGAP.

\subsection{Policy recommendations}

Based on the results of our study, several recommendations can be made that are relevant for future donor policies related to private food safety and quality standards in developing countries.

Our analyses have shown that donor support is critical to enable small-scale farmers to adopt the GlobalGAP standard. Although we found that farmers organized in groups with a donormanaged QMS are more likely to adopt GlobalGAP than farmers organized in exportermanaged groups, we suggest that public-private partnerships between exporters and donors are the preferable mechanism to facilitate GlobalGAP certification by smallholders. In particular, these schemes have been shown to be much more sustainable in the long run than donor supported certification of small-scale farmers in producer-managed groups.

However, we have also shown that GlobalGAP certification in producer-managed groups can lead to significantly higher net household incomes, while we did not identify a positive impact of certification on the net income of farmers in exporter-managed groups. This result suggests that the highest gains in terms of increasing rural incomes and alleviating poverty can be achieved by facilitating certification of farmers in producer-managed groups. However, to increase farmers' income in the long term, programs supporting the adoption of standards by independent producer groups need to be sustainable.

Different reasons can be identified for the lack of sustainability of donor-facilitated standard adoption. First, complying with GlobalGAP is often perceived as a one-time challenge that is overcome with initial certification, rather than a long-term challenge for farmers. Donors tend to emphasize the barrier that the start-up costs represent for standard adoption, while the importance of the annually recurring costs of compliance is often neglected. Since these costs are also to a large extent fixed costs, they represent a competitive disadvantage for 
smallholders in the long run (Graffham et al., 2007b, Humphrey, 2008). Second, more emphasis needs to be put on the development of functioning and efficient Quality Management Systems that form the basis for continued standard certification (Humphrey, 2008). In particular, independent farmer groups are usually not capable to operate the QMS on their own, because their members are not well educated and time constrained. The qualification requirements for positions on the QMS are high (e.g., a post high-school degree in horticulture, trainings in HACCP and GAP) and running the QMS is costly and administratively challenging. Therefore, to make GlobalGAP adoption by producer-managed groups more sustainable, one option is to link them to exporters or processors who run the QMS for farmers and provide technical, financial and managerial support. Moreover, public extension services and the private sector in developing countries have to be strengthened to provide information on food safety and quality standards, affordable assistance and trainings to farmers and farmer groups.

In addition, the dependency of small-scale farmers on donor support to adopt the GlobalGAP standard as well as the still very low number of GlobalGAP certified producers in developing countries $^{70}$ suggest that GlobalGAP is not a viable option for the majority of small-scale farmers in developing countries in the near future. Moreover, our results show that, even if access to donor support is available, it is the wealthier and more educated small-scale farmers who adopt the GlobalGAP standard, indicating that the poorest segment of smallholders has not benefited from donor interventions. In addition, the vast majority of smallholders serve domestic markets or lower value export markets where GlobalGAP is not a requirement. In these markets, however, opportunities for product differentiation equally exist and food safety and quality standard gain in relevance (Jaffee et al., 2011). Therefore, donor programs, which invest in gradually upgrading food safety systems in developing countries, and in facilitating the adoption of lower level standards by small-scale farmers may reach a higher number of farmers and thus have a higher impact on overall rural development. Moreover, increasing food safety and disseminating good agricultural practices in developing countries is also highly relevant to increase local consumers' health. Food-borne illnesses from biological or chemical contamination continue to remain one of the main health problems in many developing countries.

\footnotetext{
${ }^{70}$ For example, in 2011 only 1070 producers were certified in Kenya, 27 in Zimbabwe, 433 in Brazil, 808 in Ecuador, 263 in Thailand, 258 in Vietnam and 280 in China (FoodPlus, 2011a).
} 


\subsection{Limitations of the study and suggestions for further research}

The results of this study contribute to a better understanding of the implications of private food safety and quality standards for small-scale farmers in developing countries. Nevertheless, the scope of this study is limited and many areas for future research remain.

First, our study is limited to the analysis of short term effects of GlobalGAP certification. We assessed the impacts of GlobalGAP certification for a one-year period following the adoption of the standard. However, some of the potential impacts of certification may only occur in the long run. For example, implementing GlobalGAP is a long-term process and involves a learning effect, which is not completed with obtaining the certificate for the first time. Over time farmers may build up good and accurate knowledge about fertilizer and pesticide usage, integrated pest management and irrigation management, which may lead to higher productivity and higher product quality. Furthermore, our analysis has shown that GlobalGAP certification of farmers in producer-managed groups is often not sustainable. Yet, we cannot evaluate whether the positive effects of GlobalGAP adoption persist in following years although the certificate is not renewed. Farmers who have gained access to new remunerative markets may be able to maintain these value chain linkages even in the absence of a formal certification. Therefore, the collection of long-term panel data could be a useful extension to explain the impacts of GlobalGAP certification that occur in the long run. In addition, this study is limited to price and income effects of GlobalGAP certification, but implementing GlobalGAP may also have a positive impact on the environment (e.g., prevention of soil erosion, more efficient use of irrigation water) and on farm workers' welfare (e.g., health, working conditions, housing conditions). To evaluate the overall impact of the GlobalGAP standard, it is important to also address these effects in future studies. Moreover, this study has evaluated subgroup-specific mean treatment effects of GlobalGAP certification. Nevertheless, this may not capture the full extent of heterogeneity in treatment effects across individuals. The impact of GlobalGAP certification is likely not to be constant within subgroups of adopters and, e.g., impacts may differ depending on farm size, wealth and educational level of adopters. Therefore, studies using distributional measures, such as quantile treatment effects, could shed further light on the impact heterogeneity of GlobalGAP certification.

Finally, this study is limited to the GlobalGAP standard, which is primarily relevant for suppliers of high-value export markets. The majority of small-scale farmers in developing countries, however, are oriented towards domestic markets or lower value export markets. In 
these markets private standards are also gaining in relevance and offer opportunities for product differentiation but are less challenging to comply with than GlobalGAP. To date, there are only few studies exploring the opportunities and challenges of low and medium level standards, and consequently, these should be addressed in future studies. 


\section{Bibliography}

Altenburg, T. (2006) Donor approaches to supporting pro-poor value-chains. Report prepared for the Donor Committee for Enterprise Development Working Group on Linkages and Value Chains. German Development Institute.

Asfaw, S., Mithöfer, D. \& Waibel, H. (2009a) EU Food Safety Standards, Pesticide Use and Farm-level Productivity: The Case of High-value Crops in Kenya. Journal of Agricultural Economics, 60, 645-667.

Asfaw, S., Mithöfer, D. \& Waibel, H. (2009b) Investment in compliance with GlobalGAP standards: does it pay off for small-scale producers in Kenya? Quarterly Journal of International Agriculture, 4, 337-362.

Asfaw, S., Mithöfer, D. \& Waibel, H. (2010) Agrifood supply chain, private-sector standards, and farmers' health: evidence from Kenya. Agricultural Economics, 41, 251-263.

Ashraf, N., Giné, X. \& Karlan, D. (2009) Finding Missing Markets (and a Disturbing Epilogue): Evidence from an Export Crop Adoption and Marketing Intervention in Kenya. American Journal of Agricultural Economics, 91, 973-990.

Asian Development Bank (2012) Key Indicators for Asia and the Pacific 2012, Mandaluyong, Asian Development Bank.

Balsevich, F., Berdegue, J. A., Flores, L., Mainville, D. \& Reardon, T. (2003) Supermarkets and produce quality and safety standards in Latin America. American Journal of Agricultural Economics, 85, 1147-1154.

Battisti, A. B. D., Macgregor, J. \& Graffham, A. (2009) Standard bearers. Horticultural exports and private standards in Africa, London, International Institute for Environment and Development.

Baulch, B. \& Quisumbing, A. (2011) Testing and adjusting for attrition in household panel data. Chronic Poverty Research Centre Toolkit Note.

Becketti, S., Gould, W., Lillard, L. \& Welch, F. (1988) The Panel Study of Income Dynamics after Fourteen Years: An Evaluation. Journal of Labor Economics, 6, 472-492.

Berdegue, J. A., Balsevich, F., Flores, L. \& Reardon, T. (2005) Central American supermarkets' private standards of quality and safety in procurement of fresh fruits and vegetables. Food Policy, 30, 254-269.

Bignebat, C. \& Vagneron, I. (2011) Private certification in the Madagascar lychee export chain: business-driven or donor-driven dynamics? Working paper non-tarrif measures (NTM) impact project. 
Boselie, D., Henson, S. \& Weatherspoon, D. (2003) Supermarket procurement practices in developing countries: Redefining the roles of the public and private sectors. American Journal of Agricultural Economics, 85, 1155-1161.

Boselie, D. \& Kop, P. V. D. (2005) Institutional and organisational change in agri-food systems in developing and transitional countries: identifying opportunities for smallholders. Regoverning Markets Global Issue Paper 2. Amsterdam, Royal Tropical Institute.

Buurma, J. \& Saranak, J. (2006) Supply-chain development for fresh fruits and vegetables in Thailand. Agro-food chains and networks for development. Den Haag, Springer.

Chainuvati, C. \& Athipanan, W. (2001) Crop Diversification in Thailand. IN PAPADEMETRIOU, M. K. \& DENT, F. J. (Eds.) Crop Diversification in the AsiaPacific Region. Bangkok, Food and Agriculture Organization of the United Nations. Chemnitz, C. (2007) The Compliance Decision with Food Quality Standards on Primary Producer Level. A Case Study of the EUREPGAP Standard in the Marrocean Tomato Sector. 103rd EAAE Seminar: Adding Value to the Agro-Food Supply Chain in the Future Euro Mediterranean Space. Barcelona.

Chemnitz, C., Grethe, H. \& Kleinwechter, U. (2007) Quality Standards for Food Products - A Particular Burden for Small Producers in Developing Countries? Berlin, Department of Agricultural Economics and Social Sciences. Humboldt University of Berlin.

Chunyanuwat, P. (2005) Country Report Thailand. Proceedings Asia Regional Workshop: Implementation, Monitoring and Observance. International Code of Conduct on the Distribution and Use of Pesticides. Bangkok, FAO Regional Office for Asia and the Pacific.

Corsin, F., Funge-Smith, S. \& Clausen, J. (2007) A qualitative assessment of standards and certification schemes applicable to aqaculture in the Asia-Pacific region. Bangkok, Food and Agriculture Organization of the United Nations.

Dolan, C. \& Humphrey, J. (2000) Governance and Trade in Fresh Vegetables: The Impact of UK Supermarkets on the African Horticulture Industry. Journal of Development Studies, 37, 147-176.

Elbers, C., Gunning, J. W. \& Kinsey, B. (2007) Growth and Risk: Methodology and Micro Evidence The World Bank Economic Review, 21, 1-20.

Fafchamps, M., Hill, R. V. \& Minten, B. (2008) Quality control in nonstaple food markets: evidence from India. Agricultural Economics, 38, 251-266. 
FAO (2003) Environmental and social standards, certification and labelling for cash crops.

Rome, Food and Agriculture Organization of the United Nations.

FAO (2010) FAOSTAT. Retrieved November 30, 2012, from http://faostat.fao.org/

FAO and UNDP (2003) Gender responsive technology for poverty alleviation in Thailand.

Bangkok, Food and Agriculture Organization of the United Nations / United Nations

Development Programme.

Farina, E. M. M. Q. \& Reardon, T. (2000) Agrifood grades and standards in the extended

Mercosur: Their role in the changing agrifood system. American Journal of

Agricultural Economics, 82, 1170-1176.

Feder, G., Just, R. E. \& Zilberman, D. (1985) Adoption of Agricultural Innovations in

Developing Countries. Economic Development and Cultural Change. Washington,

D.C.

Fitzgerald, J., Gottschalk, P. \& Moffitt, R. (1998) An Analysis of Sample Attrition in Panel

Data: The Michigan Panel Study of Income Dynamics. The Journal of Human

Resources, 33, 251-299.

FoodPLUS (2009a) General Regulations. Integrated Farm Assurance. Version 3.1. Cologne, FoodPLUS GmbH.

FoodPLUS (2009b) GLOBALG.A.P. Annual report 2009. Cologne, FoodPLUS GmbH.

FoodPLUS (2010a) GLOBALG.A.P. certified producers in Thailand. Cologne, FoodPLUS

$\mathrm{GmbH}$.

FoodPLUS (2010b) Smallholder Guide for GLOBALG.A.P. Soil and Water Module. Cologne, FoodPLUS GmbH.

FoodPLUS (2011a) GLOBALG.A.P. Annual report 2011 Cologne, FoodPLUS GmbH.

FoodPLUS (2011b) GLOBALG.A.P. Control Points and Compliance Criteria. Integrated

Farm Assurance. Crops Base. Cologne, FoodPLUS GmbH.

FoodPLUS (2012a) GLOBALG.A.P.website - What we do. Retrieved November 11, 2012, from http://www.globalgap.org/uk_en/what-we-do/globalg.a.p./

FoodPLUS (2012b) GLOBALG.A.P. History. Retrieved November 11, 2012, from http://www.globalgap.org/uk_en/who-we-are/history/

FoodPLUS (2012c) GLOBALG.A.P. website. Retrieved December 1, 2012, from http://www.globalgap.org/uk_en/

FoodPLUS and GTZ (2008) Smallholder Manual. Introduction to EUREPGAP standards for fruit and vegetables and farmer group certification. Eschborn, FoodPLUS GmbH, Deutsche Gesellschaft für Technische Zusammenarbeit (GTZ) mbH. 
Gereffi, G. (1994) The organisation of buyer driven global commodity chains: how US retailers shape overseas production networks. IN KORZENIEWICZ, G. G. M. (Ed.) Commodity Chains and Global Capitalism. Westport, Connecticut, Praeger.

Ghadim, A. K. A. \& Pannell, D. J. (1999) A conceptual framework of adoption of an agricultural innovation. Agricultural Economics, 145-154.

Graffham, A., Cooper, J., Wainwright, H. \& Macgregor, J. (2007a) Small-scale farmers who withdraw from GLOBALGAP: Results of a survey in Kenya. Fresh Insights.

Graffham, A., Karehu, E. \& Macgregor, J. (2007b) Impact of EurepGAP on small-scale vegetable growers in Kenya. Fresh Insights.

Greene, W. H. (2008) Econometric Analysis, New Jersey, Person Prentice Hall.

GTZ (2010) GLOBALGAP Smallholder QMS Set-up Guide: How to establish a QMS in your group. Eschborn, Deutsche Gesellschaft für Technische Zusammenarbeit (GTZ) mbH.

Gulati, A., Minot, N., Delgado, C. \& Bora, S. (2006) Growth in high-value agriculture in Asia and the emergence of vertical links with farmers. IN SWINNEN, J. F. M. (Ed.) Global Supply Chains, Standards and the Poor: How the Globalization of Food Systems and Standards Affects Rural Development and Poverty. London, CABI Press.

Heckman, J. J., Smith, J. \& Clements, N. (1997) Making The Most Out Of Programme Evaluations and Social Experiments: Accounting For Heterogeneity in Programme Impacts. Review or Economic Sludies, 64, 487-535.

Henson, S. \& Caswell, J. (1999) Food safety regulation: an overview of contemporary issues. Food Policy, 24, 589-603.

Henson, S. \& Loader, R. (2001) Barriers to agricultural exports from developing countries: The role of sanitary and phytosanitary requirements. World Development, 29, 85-102. Henson, S., Masakure, O. \& Boselie, D. (2005) Private food safety and quality standards for fresh produce exporters: The case of Hortico Agrisystems, Zimbabwe. Food Policy, 30, 371-384.

Henson, S., Masakure, O. \& Cranfield, J. (2011) Do Fresh Produce Exporters in Sub-Saharan Africa Benefit from GlobalGAP Certification? World Development, 39, 375-386.

Henson, S. \& Reardon, T. (2005) Private agri-food standards: Implications for food policy and the agri-food system. Food Policy, 30, 241-253.

Hernandez, R., Reardon, T. \& Berdegue, J. (2007) Supermarkets, wholesalers, and tomato growers in Guatemala. Agricultural Economics, 36, 281-290.

Humphrey, J. (2008) Private Standards, Small Farmers and Donor Policy: EUREPGAP in Kenya. Sussex, University of Sussex. 
Humphrey, J. \& Memedovic, O. (2006) Global Value Chains in the Agrifood Sector. Vienna, United Nations Industrial Development Organization.

International Trade Centre (2012) Trademap. Retrieved December 2, 2012, from www.trademap.org

Jaffee, S. (2003) From Challenge to Opportunity. Transforming Kenya’s Fresh Vegetable Trade in the Context of Emerging Food Safety and Other Standards in Europe. Agriculture and Rural Development Working Paper 10. Washington, DC., World Bank.

Jaffee, S., Henson, S. \& Rios, L. D. (2011) MAKING THE GRADE: Smallholder Farmers, Emerging Standards, and Development Assistance Programs in Africa. Washington, DC, International Bank for Reconstruction and Development/The World Bank/The University of Guelph.

Jaffee, S. \& Masakure, O. (2005) Strategic use of private standards to enhance international competitiveness: Vegetable exports from Kenya and elsewhere. Food Policy, 30, 316333.

Jaffee, S., Meer, K. V. D., Henson, S., Haan, C. D., Sewadeh, M., Ignacio, L., Lamb, J. \& Lisazo, M. B. (2005) Food Safety and Agricultural Health Standards: Challenges and Opportunities for Developing Countries.

Kariuki, I. M., Loy, J.-P. \& Herzfeld, T. (2012) Farmgate Private Standards and Price Premium: Evidence From the GlobalGAP Scheme in Kenya's French Beans Marketing. Agribusiness, 28, 42-53.

Keeratipipatpong, W. (2010) Thai farm product standard certified. ThaiGAP will help reduce trade barriers Bangkok Post.

Kersting, S. \& Wollni, M. (2012) New institutional arrangements and standard adoption: Evidence from small-scale fruit and vegetable farmers in Thailand. Food Policy, 37, 452-462.

Key, N. \& Runsten, D. (1999) Contract Farming, Smallholders, and Rural Development in Latin America: The Organization of Agroprocessing Firms and the Scale of Outgrower Production. World Development, 27, 381-401.

Kleinwechter, U. \& Grethe, H. (2006) The Adoption of the Eurepgap Standard by Mango Exporters in Piura, Peru. 26th International Conference of Agricultural Economists. Gold Coast, Australia.

Maddala, G. S. (1983) Limited-dependent and qualitative variables in econometrics, Cambridge, Cambridge University Press. 
Maertens, M. \& Swinnen, J. F. M. (2009) Trade, Standards, and Poverty: Evidence from Senegal. World Development, 37, 161-178.

Manarungsan, S., Naewbanij, J. O. \& Rerngjakrabhe, T. (2005) Costs of Compliance with SPS Standards: Thailand Case Studies of Shrimp, Fresh Asparagus, and Frozen Green Soybeans. Washington, D.C., The World Bank.

Markelova, H., Meinzen-Dick, R., Hellin, J. \& Dohrn, S. (2009) Collective action for smallholder market access. Food Policy, 34, 1-7.

Mausch, K., Mithöfer, D., Aswaf, S. \& Waibel, H. (2009) Export Vegetable Production in Kenya under the EurepGAP Standard: Is Large "More Beautiful" than Small? Journal of Food Distribution Research, 40, 115-129.

Mcculloch, N. \& Ota, M. (2002) Export Horticulture and Poverty in Kenya. IDS Working Paper. Brighton, Institute of Development Studies.

Ministry of Public Health (2004) Road Map of Food Safety. Bangkok, Ministry of Public Health Thailand. Retrieved November 15, 2012 from http://www.fao.org/docrep/meeting/008/ae183e/ae183eApp.pdf

Minot, N. W. (1986) Contract Farming and Its Effect on Small Farmers in Less Developed Countries. Food Security International Development Working Papers.

Minten, B., Randrianarison, L. \& Swinnen, J. F. M. (2009) Global Retail Chains and Poor Farmers: Evidence from Madagascar. World Development, 37, 1728-1741.

Narrod, C., Roy, D., Okello, J., Avendano, B., Rich, K. \& Thorat, A. (2009) Public-private partnerships and collective action in high value fruit and vegetable supply chains. Food Policy, 34, 8-15.

Neill, S. P. \& Lee, D. R. (2001) Explaining the Adoption and Disadoption of Sustainable Agriculture: The Case of Cover Crops in Northern Honduras. Economic Development and Cultural Change, 49, 793-820.

Okello, J. J. (2005) Compliance with international food safety standards: the case of green bean production in Kenyan family farm. Michigan, Department of Agricultural Economics, Michigan State University.

Okello, J. J., Narrod, C. A. \& Roy, D. (2011) Export Standards, Market Institutions and Smallholder Farmer Exclusion from Fresh Export Vegetable High Value Chains: Experiences from Ethiopia, Kenya and Zambia. Journal of Agricultural Science, 3, 188-195. 
Okello, J. J. \& Swinton, S. M. (2007) Compliance with international food safety standards in Kenya's green bean industry: Comparison of a small- and a large-scale farm producing for export. Review of Agricultural Economics, 29, 269-285.

Otsuki, T., John S. Wilson \& Sewadeh, M. (2001) Saving two in a billion: quantifying the trade effect of European food safety standards on African exports. Food Policy, 26, 495-514.

Ouma, S. (2007) Implementing a QMS for EurepGAP standard certification under option 2: Lessons learned from the Kenyan pilot project and a way forward. Eschborn.

Ouma, S. (2010) Global Standards, Local Realities: Private Agrifood Governance and the Restructuring of the Kenyan Horticulture Industry. Economic Geography, 86, 197222.

Pingali, P. (2006) Westernization of Asian diets and the transformation of food systems: Implications for research and policy. Food Policy, 281-298.

Plianbangchang, P., Jetiyanon, K. \& Wittayaareekul, S. (2009) Pesticide use patterns among small-scale farmers: A case study from Phitsanulok, Thailand. The Southeast Asian Journal of Tropical Medicine and Public Health, 40, 401-410.

Pongsrihadulchai, A. (2009) Use of farmers' registration for agricultural policy implementation in Thailand. Bangkok, Food and Agriculture Organization of the United Nations.

Ratanawaraha, C., Senanarong, N. \& Suriyapan, P. (2001) Status of cassava in Thailand: Implications for future research and development. A review of cassava in Asia with country case studies on Thailand and Viet Nam. Rome, Food and Agriculture Organization of the United Nations.

Reardon, T., Barrett, C. B., Berdegue, J. A. \& Swinnen, J. F. M. (2009) Agrifood Industry Transformation and Small Farmers in Developing Countries. World Development, 37, 1717-1727.

Reardon, T., Henson, S. \& Gulati, A. (2010) Links between supermarkets and food prices, diet diversity and food safety in developing countries. IN HAWKES, C., BLOUIN, C., HENSON, S., DRAGER, N. \& DUBÉ, L. (Eds.) Trade, food, diet and health: perspectives and policy options. Wiley-Blackwell.

Reardon, T. \& Timmer, C. P. (2007) Transformation of markets for agricultural out-put in developing countries since 1950: how has thinking changed? . IN PINGALI, P. \& EVENSON, R. (Eds.) Handbook of Agricultural Economics Amsterdam, Elsevier. 
Reardon, T., Timmer, C. P., Barrett, C. B. \& Berdegue, J. (2003) The rise of supermarkets in Africa, Asia, and Latin America. American Journal of Agricultural Economics, 85, 1140-1146.

Reardon, T., Timmer, C. P. \& Minten, B. (2012) Supermarket revolution in Asia and emerging development strategies to include small farmers. PNAS, 109, 12332-12337.

Rigg, J. (2005) Land, Farming, Livelihoods, and Poverty: Rethinking the Links in the Rural South. World Development, 34, 180-202.

Rigg, J. \& Nattapoolwat, S. (2001) Embracing the Global in Thailand: Activism and Pragmatism in Era of Deagrarianization. World Development, 29, 945-960.

Roitner-Schobesberger, B., Darnhofer, I., Somsook, S. \& Vogel, C. R. (2008) Consumer perceptions of organic foods in Bangkok, Thailand. Food Policy, 33, 112-121.

Roy, D. \& Thorat, A. (2008) Success in High Value Horticultural Export Markets for the Small Farmers: The Case of Mahagrapes in India. World Development.

Sardsud, V. (2007) V. National Experiences: Thailand. Challenges and Opportunities Arising from Private Standards on Food Safety and Environment for Exporters of Fresh Fruit and Vegetables in Asia: Experience of Malysia, Thailand and Viet Nam. New York and Geneva, United Nations.

Shaw, K. L. (1996) An Empirical Analysis of Risk Aversion and Income Growth. Journal of Labor Economics, 14, 626-653.

Shepard, A. W. (2006) Quality and safety in the traditional horticultural marketing chains of Asia. Rome, Food and Agriculture Organization of the United Nations.

Shepherd, A. W. (2005) The implications of supermarket development for horticultural farmers and traditional marketing systems in Asia Rome, Food and Agriculture Organization of the United Nations.

Sriboonchitta, S. \& Wiboonpoongse, A. (2008) Overview of Contract Farming in Thailand: Lessons Learned. ADB Institute Discussion Paper No. 112. Tokyo, Asian Development Bank.

Subervie, J. \& Vagneron, I. (2012) Can Fresh Produce Farmers Benefit from Global Gap Certification? The case of lychee producers in Madagascar. International Association of Agricultural Economists (IAAE) Triennial Conference. Foz do Iguaçu, Brazil.

Tesco (2005) Tesco Corporate Responsibility Review 2005. Retrieved December 1, 2012, from http://www.tesco.com/csr/g/g4.html

Ussavasodhi, S. (2011) Vegetable exporters urged to use Thai GAP standard. Thai Financial Post. 
Vagneron, I., Faure, G. \& Loeillet, D. (2009) Is there a pilot in the chain? Identifying the key drivers of change in the fresh pineapple sector. Food Policy, 34, 437-446.

Van De Ven, W. P. M. M. \& Van Praag, B. M. S. (1981) The demand for deductibles in private health insurance: A probit model with sample selection. Journal of Econometrics, 17, 229-252.

Vorley, B. \& Fox, T. (2004) Global Food Chains - Constraints and Opportunities for Smallholders. Retrieved December 11, 2012 from http://www.oecd.org/dataoecd/24/60/36562581.pdf

Wannamolee, W. (2008) Development of Good Agricultural Practices (GAP) for Fruit and Vegetables in Thailand. Bangkok, National Bureau of Agricultural Commodity and Food Standards. Retrieved November 11, 2012 from http://www.dld.go.th/organic/news52/audotor_35Mar09/Aj.Wiboonwan/ThailandsGAP_report.doc

Wattanavaekin, W. (2011) Certification for International Export Markets Bangkok, Deutsche Gesellschaft für Internationale Zusammenarbeit (GIZ).

Weinberger, K. \& Lumpkin, T. A. (2007) Diversification into horticulture and poverty reduction: A research agenda. World Development, 35, 1464-1480.

Wiboonpongse, A. \& Sriboonchitta, S. (2004) Regoverning markets: securing small producer participation in restructured national and regional agri-food systems in Thailand. Chiang Mai, Chiang Mai University.

Wikipedia. (2012) Provinces of Thailand. Retrieved December 5, 2012 from htttp://en.wikipedia.org/wiki/Provinces_of_Thailand

Will, M. (2010) Integrating Smallholders into Global Supply Chains. GLOBALGAP Option 2 Smallholder Group Certification Generic Manual: Lessons learnt in pilot projects in Kenya, Ghana, Thailand and Macedonia. Eschborn, Deutsche Gesellschaft für Technische Zusammenheit (GTZ) mbH.

Wipplinger, G., Phongsathorn, V. \& Watanakeeree, G. (2006) Quality Infrastructure - A Vital Aspect of Business Environment for Enterprise Development - A Case of Thai Fresh Fruit and Vegetables Industry. Bangkok, Thai-German Programme for Enterprise Competitiveness.

Wooldridge, J. M. (2010) Econometric Analysis of Cross Section and Panel Data, Cambridge, Massachusetts, The MIT Press.

World Bank (2007) Agriculture for development. World Development Report. Washington, D.C., The World Bank. 
World Bank (2012) Thailand Overview. The World Bank. Retrieved December 1, 2012 from http://www.worldbank.org/en/country/thailand/overview 


\section{Appendices}

Appendix I: Sampling provinces and districts

Table A1: Sampling provinces and districts

\begin{tabular}{|c|c|c|c|}
\hline Province & District & $\begin{array}{l}\text { Number of farmers } \\
\text { interviewed in } 2010\end{array}$ & $\begin{array}{l}\text { Number of farmers } \\
\text { interviewed in } 2011\end{array}$ \\
\hline \multirow[t]{2}{*}{ Ayuttayah } & Ladbualuang & 4 & 2 \\
\hline & Bang Pa-in & 1 & 1 \\
\hline \multirow[t]{2}{*}{ Chachoengsao } & Sanam Chai Khet & 1 & 1 \\
\hline & Tha Takiap & 7 & 4 \\
\hline Chiang Mai & Fang & 14 & 14 \\
\hline \multirow[t]{7}{*}{ Chumporn } & Lamae & 3 & 0 \\
\hline & Lang Suan & 16 & 13 \\
\hline & Mueang Chumporn & 19 & 15 \\
\hline & Phato & 12 & 6 \\
\hline & Sawi & 3 & 2 \\
\hline & Thung Tako & 2 & 2 \\
\hline & Pathio & 1 & 1 \\
\hline \multirow[t]{4}{*}{ Kanchanaburi } & Tha Maka & 1 & 1 \\
\hline & Tha Muang & 1 & 1 \\
\hline & Bo Phloi & 5 & 4 \\
\hline & Mueang Kanchanaburi & 1 & 0 \\
\hline \multirow[t]{5}{*}{ Nakhon Pathom } & Kamphaeng Saen & 38 & 23 \\
\hline & Mueang Nakhon Pathom & 5 & 3 \\
\hline & Sam Phran & 6 & 6 \\
\hline & Bang Len & 10 & 7 \\
\hline & Don Tum & 1 & 0 \\
\hline Pathum Thani & Lat Lum Kaeo & 1 & 0 \\
\hline Phayao & Mae Chai & 73 & 63 \\
\hline Phichit & Sak Lek & 6 & 4 \\
\hline Prachin Buri & Si Maha Phot & 6 & 4 \\
\hline \multirow[t]{2}{*}{ Ratchaburi } & Ban Pong & 2 & 2 \\
\hline & Mueang Ratchaburi & 13 & 12 \\
\hline Sa Kaew & Wang Sombun & 20 & 15 \\
\hline Samut Sakhorn & Ban Phaeo & 13 & 10 \\
\hline Saraburi & Nong Khae & 2 & 2 \\
\hline
\end{tabular}

Source: Own data 


\section{Appendix II: Analysis of sample attrition}

Table A2: Attrition probit test for net household income

\begin{tabular}{lcccc}
\hline Variables (2009 values) & Coefficient & $\begin{array}{c}\text { Standard } \\
\text { error }\end{array}$ & $\mathbf{z}$ & $\mathbf{P}>|\mathbf{z}|$ \\
\hline North Thailand (0/1) & -0.46 & 0.23 & -1.94 & 0.05 \\
South Thailand (0/1) & 0.18 & 0.27 & 0.66 & 0.51 \\
East Thailand (0/1) & 0.04 & 0.31 & 0.14 & 0.89 \\
Number of household members & 0.00 & 0.07 & 0.04 & 0.97 \\
Share of adults that are male (0/1) & 0.22 & 0.62 & 0.36 & 0.72 \\
Share of adults that are female (0/1) & 0.17 & 0.68 & 0.25 & 0.80 \\
Age of the household head & -0.02 & 0.01 & -2.04 & 0.04 \\
Years of education (household head) & -0.04 & 0.03 & -1.31 & 0.19 \\
Off-farm employment (0/1) & -0.12 & 0.21 & -0.59 & 0.56 \\
Household head's main occupation is agriculture (0/1) & -0.02 & 0.25 & -0.08 & 0.94 \\
Wealth index & 0.03 & 0.08 & 0.36 & 0.72 \\
Farm size (rai) & 0.00 & 0.00 & 0.99 & 0.32 \\
Net household income (THB) & 0.00 & 0.00 & -0.42 & 0.67 \\
Development program participation (0/1) & -0.76 & 0.24 & -3.22 & 0.00 \\
Internal control group (0/1) & -0.21 & 0.23 & -0.89 & 0.37 \\
Constant & 0.88 & 0.88 & 1.00 & 0.32 \\
\hline Number of observations: 287 & & &
\end{tabular}

Number of observations: 287

Log likelihood: -147.22999

Pseudo R-squared: 0.0954

Note: The dependent variable is 'Attrition'.

Source: Own data

As a result of the attrition probit test, we find that the variables 'North Thailand', 'age of the household head' and 'development program participation' are significant predictors of sample attrition. A Wald test is performed to see whether these variables are jointly equal to zero. The Chi-squared statistic (19.00) shows that the variables are jointly statistically different from zero (P-value 0.00). Thus, we can conclude that the three variables are significant predictors of attrition. 
Table A3: Pooling test for net household income

\begin{tabular}{|c|c|c|c|c|}
\hline Variables (2009 values) & Coefficient & $\begin{array}{c}\text { Standard } \\
\text { error }\end{array}$ & $\mathbf{z}$ & $\mathbf{P}>|\mathbf{z}|$ \\
\hline South Thailand $(0 / 1)$ & -0.51 & 0.08 & -6.59 & 0.00 \\
\hline East Thailand (0/1) & -0.46 & 0.09 & -4.84 & 0.00 \\
\hline Number of household members & -0.09 & 0.02 & -4.47 & 0.00 \\
\hline Share of adults that are male $(0 / 1)$ & -0.13 & 0.17 & -0.75 & 0.45 \\
\hline Share of adults that are female $(0 / 1)$ & -0.05 & 0.19 & -0.23 & 0.82 \\
\hline Age of the household head & 0.00 & 0.00 & 1.48 & 0.14 \\
\hline Years of education (household head) & -0.01 & 0.01 & -1.57 & 0.12 \\
\hline Off-farm employment $(0 / 1)$ & -0.01 & 0.06 & -0.14 & 0.89 \\
\hline Household head's main occupation is agriculture ( $0 / 1)$ & 0.04 & 0.07 & 0.63 & 0.53 \\
\hline Wealth index & -0.06 & 0.02 & -2.60 & 0.01 \\
\hline Farm size (rai) & 0.00 & 0.00 & 1.37 & 0.17 \\
\hline Net household income (THB) & 0.00 & 0.00 & 0.99 & 0.32 \\
\hline Development program participation (0/1) & 0.13 & 0.07 & 1.79 & 0.08 \\
\hline Internal control group $(0 / 1)$ & -0.03 & 0.08 & -0.36 & 0.72 \\
\hline Attrition $(0 / 1)$ & -0.68 & 0.57 & -1.20 & 0.23 \\
\hline Attrition (0/1) * North Thailand (0/1) & 1.00 & 0.14 & 6.95 & 0.00 \\
\hline Attrition $(0 / 1) *$ South Thailand $(0 / 1)$ & 0.51 & 0.16 & 3.21 & 0.00 \\
\hline Attrition $(0 / 1) *$ East Thailand $(0 / 1)$ & 0.46 & 0.19 & 2.41 & 0.02 \\
\hline Attrition $(0 / 1) *$ Number of household members & 0.09 & 0.04 & 2.31 & 0.02 \\
\hline Attrition $(0 / 1) *$ Share of adults that are male $(0 / 1)$ & 0.13 & 0.40 & 0.32 & 0.75 \\
\hline Attrition $(0 / 1) *$ Share of adults that are female $(0 / 1)$ & 0.05 & 0.43 & 0.11 & 0.92 \\
\hline Attrition $(0 / 1) *$ Years of education (household head) & 0.00 & 0.01 & -0.82 & 0.41 \\
\hline Attrition $(0 / 1) *$ Age of the household head & 0.01 & 0.02 & 0.73 & 0.47 \\
\hline Attrition $(0 / 1) *$ Off-farm employment $(0 / 1)$ & 0.01 & 0.12 & 0.07 & 0.94 \\
\hline $\begin{array}{l}\text { Attrition }(0 / 1) * \text { Household head's main } \\
\text { occupation is agriculture }(0 / 1)\end{array}$ & -0.04 & 0.15 & -0.30 & 0.76 \\
\hline Attrition $(0 / 1) *$ Wealth index & 0.06 & 0.05 & 1.17 & 0.24 \\
\hline Attrition $(0 / 1) *$ Farm size (rai) & 0.00 & 0.00 & -0.72 & 0.47 \\
\hline Attrition $(0 / 1) *$ Net household income (THB) & 0.00 & 0.00 & -0.94 & 0.35 \\
\hline $\begin{array}{l}\text { Attrition }(0 / 1) * \text { Development program } \\
\text { participation }(0 / 1)\end{array}$ & -0.13 & 0.15 & -0.90 & 0.37 \\
\hline Attrition $(0 / 1) *$ Internal control group $(0 / 1)$ & 0.03 & 0.13 & 0.22 & 0.83 \\
\hline Constant & 0.68 & 0.24 & 2.81 & 0.01 \\
\hline
\end{tabular}

Note: The dependent variable is 'North Thailand'.

Source: Own data

An F-test of the joint significance of the attrition dummy and the variables interacted with the attrition dummy is used to find out whether the coefficients from the explanatory variables differ between households who remain in the panel and households who attrit. The F-statistic of 4.52 (P-Value 0.00) indicates that the null hypothesis that attrition is random can be rejected. 
Table A4: Attrition probit test for mean F\&V prices

\begin{tabular}{lcccc}
\hline Variables (2009 values) & Coefficient & $\begin{array}{c}\text { Standard } \\
\text { error }\end{array}$ & $\mathbf{z}$ & $\mathbf{P}>|\mathbf{z}|$ \\
\hline North Thailand (0/1) & -0.25 & 0.23 & -1.11 & 0.27 \\
South Thailand (0/1) & -0.01 & 0.28 & -0.04 & 0.97 \\
East Thailand (0/1) & -0.29 & 0.33 & -0.89 & 0.37 \\
Number of household members & -0.02 & 0.07 & -0.31 & 0.76 \\
Share of adults that are male (0/1) & 0.01 & 0.61 & 0.01 & 0.99 \\
Share of adults that are female (0/1) & 0.13 & 0.67 & 0.20 & 0.84 \\
Age of the household head & -0.02 & 0.01 & -1.63 & 0.10 \\
Years of education (household head) & -0.04 & 0.03 & -1.21 & 0.23 \\
Off-farm employment (0/1) & -0.14 & 0.21 & -0.69 & 0.49 \\
Household head's main occupation is agriculture (0/1) & -0.18 & 0.25 & -0.73 & 0.47 \\
Wealth index & 0.06 & 0.08 & 0.84 & 0.40 \\
Farm size (rai) & 0.00 & 0.00 & 1.43 & 0.15 \\
Mean F\&V price (THB) & -0.02 & 0.01 & -2.14 & 0.03 \\
Development program participation (0/1) & -0.88 & 0.24 & -3.72 & 0.00 \\
Internal control group (0/1) & -0.29 & 0.23 & -1.24 & 0.22 \\
Constant & 1.53 & 0.88 & 1.75 & 0.08 \\
\hline
\end{tabular}

Number of observations

Log likelihood

Pseudo R-squared

Note: The dependent variable is ‘Attrition'.

Source: Own data

As a result of the attrition probit test, we find that the variables 'age of the household head', 'mean F\&V price' and 'development program participation' are significant predictors of sample attrition. A Wald test is performed to see whether these variables are jointly equal to zero. The Chi-squared statistic (25.09) shows that the variables are jointly statistically different from zero (P-value 0.00). Thus, we can conclude that the three variables are significant predictors of attrition. 
Table A5: Pooling test for mean F\&V price

\begin{tabular}{|c|c|c|c|c|}
\hline Variables (2009 values) & Coefficient & $\begin{array}{c}\text { Standard } \\
\text { error }\end{array}$ & $\mathbf{z}$ & $\mathbf{P}>|\mathbf{z}|$ \\
\hline South Thailand $(0 / 1)$ & -0.47 & 0.07 & -6.42 & 0.00 \\
\hline East Thailand (0/1) & -0.55 & 0.09 & -5.89 & 0.00 \\
\hline Number of household members & -0.07 & 0.02 & -3.69 & 0.00 \\
\hline Share of adults that are male $(0 / 1)$ & -0.05 & 0.16 & -0.29 & 0.77 \\
\hline Share of adults that are female $(0 / 1)$ & 0.06 & 0.18 & 0.33 & 0.74 \\
\hline Age of the household head & 0.00 & 0.00 & 1.01 & 0.31 \\
\hline Years of education (household head) & -0.01 & 0.01 & -1.09 & 0.28 \\
\hline Off-farm employment (0/1) & 0.00 & 0.06 & 0.02 & 0.98 \\
\hline Household head's main occupation is agriculture $(0 / 1)$ & 0.08 & 0.07 & 1.13 & 0.26 \\
\hline Wealth index & -0.04 & 0.02 & -1.78 & 0.08 \\
\hline Farm size (rai) & 0.00 & 0.00 & 1.20 & 0.23 \\
\hline Net household income (THB) & -0.01 & 0.00 & -4.60 & 0.00 \\
\hline Development program participation (0/1) & 0.28 & 0.08 & 3.69 & 0.00 \\
\hline Internal control group $(0 / 1)$ & 0.13 & 0.08 & 1.55 & 0.12 \\
\hline Attrition (0/1) & -0.61 & 0.50 & -1.22 & 0.22 \\
\hline Attrition $(0 / 1) *$ North Thailand $(0 / 1)$ & 1.00 & 0.11 & 9.06 & 0.00 \\
\hline Attrition $(0 / 1) *$ South Thailand $(0 / 1)$ & 0.47 & 0.16 & 3.01 & 0.00 \\
\hline Attrition $(0 / 1) *$ East Thailand $(0 / 1)$ & 0.55 & 0.19 & 2.91 & 0.00 \\
\hline Attrition $(0 / 1) *$ Number of household members & 0.07 & 0.03 & 2.03 & 0.04 \\
\hline Attrition $(0 / 1) *$ Share of adults that are male $(0 / 1)$ & 0.05 & 0.35 & 0.14 & 0.89 \\
\hline Attrition $(0 / 1) *$ Share of adults that are female $(0 / 1)$ & -0.06 & 0.38 & -0.16 & 0.87 \\
\hline Attrition $(0 / 1) *$ Years of education (household head) & 0.00 & 0.00 & -0.61 & 0.54 \\
\hline Attrition $(0 / 1) *$ Age of the household head & 0.01 & 0.02 & 0.54 & 0.59 \\
\hline Attrition $(0 / 1) *$ Off-farm employment $(0 / 1)$ & 0.00 & 0.11 & -0.01 & 0.99 \\
\hline $\begin{array}{l}\text { Attrition }(0 / 1) * \text { Household head's main } \\
\text { occupation is agriculture }(0 / 1)\end{array}$ & -0.08 & 0.13 & -0.59 & 0.55 \\
\hline Attrition $(0 / 1) *$ Wealth index & 0.04 & 0.04 & 0.84 & 0.40 \\
\hline Attrition $(0 / 1) *$ Farm size (rai) & 0.00 & 0.00 & -0.72 & 0.47 \\
\hline Attrition (0/1) * Net household income (THB) & 0.01 & 0.00 & 1.85 & 0.07 \\
\hline $\begin{array}{l}\text { Attrition }(0 / 1) * \text { Development program } \\
\text { participation }(0 / 1)\end{array}$ & -0.28 & 0.13 & -2.16 & 0.03 \\
\hline Attrition $(0 / 1) *$ Internal control group $(0 / 1)$ & -0.13 & 0.12 & -1.03 & 0.31 \\
\hline Constant & 0.61 & 0.23 & 2.59 & 0.01 \\
\hline
\end{tabular}

Note: The dependent variable is 'North Thailand'.

Source: Own data

An F-test of the joint significance of the attrition dummy and the variables interacted with the attrition dummy is used to find out whether the coefficients from the explanatory variables differ between households who remain in the panel and households who attrit. The F-statistic of 6.13 (P-Value 0.00) indicates that the null hypothesis that attrition is random can be rejected. 


\section{Appendix III: Impact of GlobalGAP certification - full models}

Table A6: Determinants of F\&V producer prices (full model)

\begin{tabular}{|c|c|c|c|c|}
\hline & (1) & $(2)$ & (3) & (4) \\
\hline GlobalGAP certified $(0 / 1)^{\mathrm{a}}$ & $\begin{array}{c}0.36 * * * \\
(0.12)\end{array}$ & $\begin{array}{c}0.20 \\
(0.12)\end{array}$ & - & - \\
\hline $\begin{array}{l}\text { GlobalGAP certified } \\
\text { (exporter group) }(0 / 1)^{a}\end{array}$ & - & - & $\begin{array}{l}-0.02 \\
(0.15)\end{array}$ & $\begin{array}{c}0.01 \\
(0.13)\end{array}$ \\
\hline 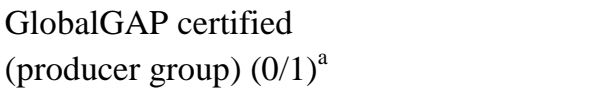 & - & - & $\begin{array}{c}0.52 * * * \\
(0.14)\end{array}$ & $\begin{array}{l}0.29 * \\
(0.15)\end{array}$ \\
\hline $\begin{array}{l}\text { Total quantity of F\&V sold } \\
(1000 \mathrm{~kg})\end{array}$ & $\begin{array}{c}0.00 \\
(0.00)\end{array}$ & $\begin{array}{l}0.00 * * \\
(0.00)\end{array}$ & $\begin{array}{c}0.00 \\
(0.00)\end{array}$ & $\begin{array}{l}0.00 * \\
(0.00)\end{array}$ \\
\hline Share of F\&V sold to high-value markets & - & $\begin{array}{l}0.23 * * \\
(0.11)\end{array}$ & - & $\begin{array}{l}0.22 * * \\
(0.11)\end{array}$ \\
\hline Share of F\&V sold that is graded & - & $\begin{array}{c}0.45^{* *} \\
(0.21)\end{array}$ & - & $\begin{array}{l}0.45^{* *} \\
(0.21)\end{array}$ \\
\hline $\begin{array}{l}\text { Share of F\&V sold under a } \\
\text { market-specification contract }\end{array}$ & - & $\begin{array}{c}0.26 * * * \\
(0.10)\end{array}$ & - & $\begin{array}{l}0.25 * * \\
(0.11)\end{array}$ \\
\hline $\begin{array}{l}\text { Share of F\&V sold under a } \\
\text { production-management contract }\end{array}$ & - & $\begin{array}{c}0.15 \\
(0.11)\end{array}$ & - & $\begin{array}{c}0.15 \\
(0.11)\end{array}$ \\
\hline $\begin{array}{l}\text { Share of } F \& V \text { sold for which resources } \\
\text { are provided }\end{array}$ & - & $\begin{array}{c}-0.02 \\
(0.09)\end{array}$ & - & $\begin{array}{l}-0.01 \\
(0.10)\end{array}$ \\
\hline Year $2010(0 / 1)^{b}$ & $\begin{array}{c}0.26 * * * \\
(0.09)\end{array}$ & $\begin{array}{c}0.23^{* * *} \\
(0.07)\end{array}$ & $\begin{array}{c}0.26 * * * \\
(0.09)\end{array}$ & $\begin{array}{c}0.23^{* * *} \\
(0.07)\end{array}$ \\
\hline Share of F\&V area under spring onion & $\begin{array}{c}6.07 * * * \\
(1.77)\end{array}$ & $\begin{array}{c}3.49 * * * \\
(1.13)\end{array}$ & $\begin{array}{c}6.67 * * * \\
(1.35)\end{array}$ & $\begin{array}{c}3.83 * * * \\
(1.22)\end{array}$ \\
\hline Share of F\&V area under coriander & $\begin{array}{r}-13.22 \\
(9.36)\end{array}$ & $\begin{array}{c}-4.96 \\
(7.15)\end{array}$ & $\begin{array}{c}-14.02 * \\
(8.03)\end{array}$ & $\begin{array}{c}-5.41 \\
(7.20)\end{array}$ \\
\hline Share of $F \& V$ area under egg plant & $\begin{array}{l}3.50 * \\
(2.03)\end{array}$ & $\begin{array}{c}0.52 \\
(1.74)\end{array}$ & $\begin{array}{c}4.12 * * * \\
(1.66)\end{array}$ & $\begin{array}{c}0.89 \\
(1.79)\end{array}$ \\
\hline Share of F\&V area under baby corn & $\begin{array}{c}6.16 * * * \\
(2.14)\end{array}$ & $\begin{array}{c}3.46^{* *} \\
(1.48)\end{array}$ & $\begin{array}{c}6.75 * * * \\
(1.69)\end{array}$ & $\begin{array}{c}3.78 \\
(1.58)^{* *}\end{array}$ \\
\hline Share of F\&V area under celery & $\begin{array}{l}-11.39 \\
(9.37)\end{array}$ & $\begin{array}{l}-2.85 \\
(7.10)\end{array}$ & $\begin{array}{l}-12.20 \\
(8.04)\end{array}$ & $\begin{array}{c}-3.32 \\
(7.16)\end{array}$ \\
\hline Share of F\&V area under yard long bean & $\begin{array}{c}8.02 * * * \\
(2.32)\end{array}$ & $\begin{array}{c}4.44 * * \\
(2.01)\end{array}$ & $\begin{array}{c}8.48 * * * \\
(2.02)\end{array}$ & $\begin{array}{c}4.74 * * \\
(2.06)\end{array}$ \\
\hline $\begin{array}{l}\text { Share of F\&V area under water morning } \\
\text { glory }\end{array}$ & $\begin{array}{l}-0.81 \\
(0.99)\end{array}$ & $\begin{array}{c}-1.11^{* * *} \\
(0.39)\end{array}$ & $\begin{array}{l}-0.08 \\
(0.81)\end{array}$ & $\begin{array}{l}-0.73 \\
(0.48)\end{array}$ \\
\hline Share of F\&V area under green okra & $\begin{array}{c}5.93^{* * *} \\
(1.77)\end{array}$ & $\begin{array}{l}2.92^{* *} \\
(1.30)\end{array}$ & $\begin{array}{c}6.51^{* * *} \\
(1.35)\end{array}$ & $\begin{array}{l}3.26^{* *} \\
(1.38)\end{array}$ \\
\hline Share of F\&V area under chili & $\begin{array}{c}6.73^{* * *} \\
(1.85)\end{array}$ & $\begin{array}{c}4.04^{* * *} \\
(1.41)\end{array}$ & $\begin{array}{c}7.60 * * * \\
(1.45)\end{array}$ & $\begin{array}{c}4.53^{* * *} \\
(1.46)\end{array}$ \\
\hline Share of F\&V area under asparagus & $\begin{array}{c}7.63^{* * *} \\
(2.10)\end{array}$ & $\begin{array}{c}4.27 * * * \\
(1.47)\end{array}$ & $\begin{array}{c}8.35 * * * \\
(1.61)\end{array}$ & $\begin{array}{c}4.68 * * * \\
(1.57)\end{array}$ \\
\hline Share of F\&V area under papaya & $\begin{array}{c}6.25^{* * *} \\
(2.49)\end{array}$ & $\begin{array}{c}2.82 \\
(2.03)\end{array}$ & $\begin{array}{c}6.84 * * * \\
(2.20)\end{array}$ & $\begin{array}{c}3.19 \\
(2.07)\end{array}$ \\
\hline Share of F\&V area under dragon fruit & $\begin{array}{l}7.01 * * * \\
(2.45)\end{array}$ & $\begin{array}{l}3.83^{* *} \\
(1.95)\end{array}$ & $\begin{array}{c}7.60 * * * \\
(2.15)\end{array}$ & $\begin{array}{c}4.19 * * \\
(1.99)\end{array}$ \\
\hline Share of F\&V area under mango & $\begin{array}{c}1.46 \\
(2.36)\end{array}$ & $\begin{array}{l}-1.02 \\
(2.01)\end{array}$ & $\begin{array}{c}2.04 \\
(2.06)\end{array}$ & $\begin{array}{l}-0.68 \\
(2.06)\end{array}$ \\
\hline
\end{tabular}




\begin{tabular}{|c|c|c|c|c|}
\hline Share of F\&V area under mangosteen & $\begin{array}{l}-1.93 \\
(3.85)\end{array}$ & $\begin{array}{l}-5.13^{*} \\
(2.84)\end{array}$ & $\begin{array}{c}0.40 \\
(3.58)\end{array}$ & $\begin{array}{l}-3.82 \\
(3.06)\end{array}$ \\
\hline Share of F\&V area under lychee & $\begin{array}{l}4.37 * \\
(2.37)\end{array}$ & $\begin{array}{c}1.34 \\
(1.93)\end{array}$ & $\begin{array}{c}4.89 * * \\
(2.08)\end{array}$ & $\begin{array}{c}1.67 \\
(1.99)\end{array}$ \\
\hline Share of F\&V area under longgong & $\begin{array}{l}-2.87 \\
(3.86)\end{array}$ & $\begin{array}{c}-6.49 * * \\
(2.94)\end{array}$ & $\begin{array}{l}-0.54 \\
(3.59)\end{array}$ & $\begin{array}{c}-5.17 * \\
(3.16)\end{array}$ \\
\hline Share of F\&V area under banana & $\begin{array}{l}-0.67 \\
(3.84)\end{array}$ & $\begin{array}{l}-4.18 \\
(2.86)\end{array}$ & $\begin{array}{c}1.67 \\
(3.56)\end{array}$ & $\begin{array}{l}-2.85 \\
(3.09)\end{array}$ \\
\hline Share of F\&V area under durian & $\begin{array}{c}-0.92 \\
(3.83)\end{array}$ & $\begin{array}{l}-4.65 \\
(2.88)\end{array}$ & $\begin{array}{c}1.41 \\
(3.55)\end{array}$ & $\begin{array}{l}-3.32 \\
(3.11)\end{array}$ \\
\hline Share of F\&V area under guava & $\begin{array}{c}5.59 * * * \\
(1.79)\end{array}$ & $\begin{array}{c}3.02 * * \\
(1.29)\end{array}$ & $\begin{array}{c}6.26^{* * *} \\
(1.37)\end{array}$ & $\begin{array}{c}3.41 * * * \\
(1.38)\end{array}$ \\
\hline Share of F\&V area under rambutan & $\begin{array}{c}-1.52 \\
(3.92)\end{array}$ & $\begin{array}{l}-4.62 \\
(2.96)\end{array}$ & $\begin{array}{c}0.83 \\
(3.66)\end{array}$ & $\begin{array}{l}-3.30 \\
(3.18)\end{array}$ \\
\hline Share of F\&V area under coconut & $\begin{array}{l}-2.30 \\
(3.94)\end{array}$ & $\begin{array}{l}-4.87 * \\
(2.92)\end{array}$ & $\begin{array}{c}0.05 \\
(3.69)\end{array}$ & $\begin{array}{l}-3.56 \\
(3.13)\end{array}$ \\
\hline Share of F\&V area under longan & $\begin{array}{l}4.03 * \\
(2.39)\end{array}$ & $\begin{array}{c}1.24 \\
(1.88)\end{array}$ & $\begin{array}{c}4.50 * * \\
(2.10)\end{array}$ & $\begin{array}{c}1.55 \\
(1.92)\end{array}$ \\
\hline Share of F\&V area under fingerroot & $\begin{array}{c}6.53 * * * \\
(2.08)\end{array}$ & $\begin{array}{c}3.30 * * \\
(1.49)\end{array}$ & $\begin{array}{c}7.30 * * * \\
(1.58)\end{array}$ & $\begin{array}{c}3.75^{* *} \\
(1.60)\end{array}$ \\
\hline Share of F\&V area under marian plum & $\begin{array}{c}14.52 * * * \\
(2.52)\end{array}$ & $\begin{array}{c}11.67 * * * \\
(1.96)\end{array}$ & $\begin{array}{c}15.07 * * * \\
(2.24)\end{array}$ & $\begin{array}{c}12.00 * * * \\
(2.00)\end{array}$ \\
\hline Share of F\&V area under acacia penata & $\begin{array}{c}-2.45 \\
(5.48)\end{array}$ & $\begin{array}{c}-3.19 \\
(4.60)\end{array}$ & $\begin{array}{c}-1.27 \\
(5.32)\end{array}$ & $\begin{array}{l}-2.59 \\
(4.71)\end{array}$ \\
\hline Share of F\&V area under santol tropical & $\begin{array}{c}4.00 \\
(2.50)\end{array}$ & $\begin{array}{c}0.39 \\
(2.27)\end{array}$ & $\begin{array}{l}4.13^{*} \\
(2.23)\end{array}$ & $\begin{array}{c}0.50 \\
(2.31)\end{array}$ \\
\hline Share of F\&V area under cucumber & $\begin{array}{c}6.35^{* * *} \\
(2.32)\end{array}$ & $\begin{array}{c}2.82 \\
(2.07)\end{array}$ & $\begin{array}{c}6.92 * * * \\
(2.01)\end{array}$ & $\begin{array}{c}3.18 \\
(2.13)\end{array}$ \\
\hline Share of F\&V area under gourd & $\begin{array}{c}-22.20 * * \\
(11.35)\end{array}$ & $\begin{array}{c}-20.90 * * \\
(9.59)\end{array}$ & $\begin{array}{l}-17.65 \\
(11.49)\end{array}$ & $\begin{array}{c}-18.74^{*} \\
(9.94)\end{array}$ \\
\hline Share of F\&V area under melons & $\begin{array}{c}7.65^{* * *} \\
(2.50)\end{array}$ & $\begin{array}{c}5.11^{* *} \\
(2.16)\end{array}$ & $\begin{array}{c}8.17 * * * \\
(2.22)\end{array}$ & $\begin{array}{c}5.43^{* *} \\
(2.21)\end{array}$ \\
\hline Share of F\&V area under other fruits ${ }^{c}$ & $\begin{array}{c}6.63 * * * \\
(2.36)\end{array}$ & $\begin{array}{c}3.74^{* *} \\
(1.92)\end{array}$ & $\begin{array}{c}7.14^{* * *} \\
(2.07)\end{array}$ & $\begin{array}{c}4.05 * * \\
(1.97)\end{array}$ \\
\hline $\begin{array}{l}\text { Share of F\&V area under other } \\
\text { vegetables }^{\mathrm{d}}\end{array}$ & $\begin{array}{l}8.21^{* * *} \\
(2.17)\end{array}$ & $\begin{array}{l}4.59 * * * \\
(1.63)\end{array}$ & $\begin{array}{l}8.99 * * * \\
(1.71)\end{array}$ & $\begin{array}{c}5.04 * * * \\
(1.72)\end{array}$ \\
\hline Constant & $\begin{array}{l}-1.34 \\
(2.08)\end{array}$ & $\begin{array}{c}1.15 \\
(1.54)\end{array}$ & $\begin{array}{l}-2.22 \\
(1.75)\end{array}$ & $\begin{array}{c}0.64 \\
(1.62)\end{array}$ \\
\hline Number of observations & 406 & 406 & 406 & 406 \\
\hline R-squared & 0.46 & 0.55 & 0.47 & 0.55 \\
\hline Hausman test & $1.61^{* *}$ & $1.49 * *$ & $1.51^{* *}$ & $1.33^{*}$ \\
\hline
\end{tabular}

Notes: The dependent variable is log mean F\&V price. Coefficient estimates are shown with cluster robust standard errors in parentheses. Statistical significance at the $1 \%(* * *), 5 \%\left({ }^{* *}\right)$ and $10 \%(*)$ levels.

${ }^{\mathrm{a}}$ The reference group is non-certified farmers.

$\mathrm{b}$ The reference year is 2009 .

c Included are lemon, rose apple, salacca, grape.

d Included are lemon grass, garlic chives, pigeon pea, pumpkin, wild betel leaf, spinach, tomato, Chinese kale, red leaf lettuce, parkia speciosa, houttuynia.

Source: Own data 
Table A7: Determinants of net household income (USD) (full model)

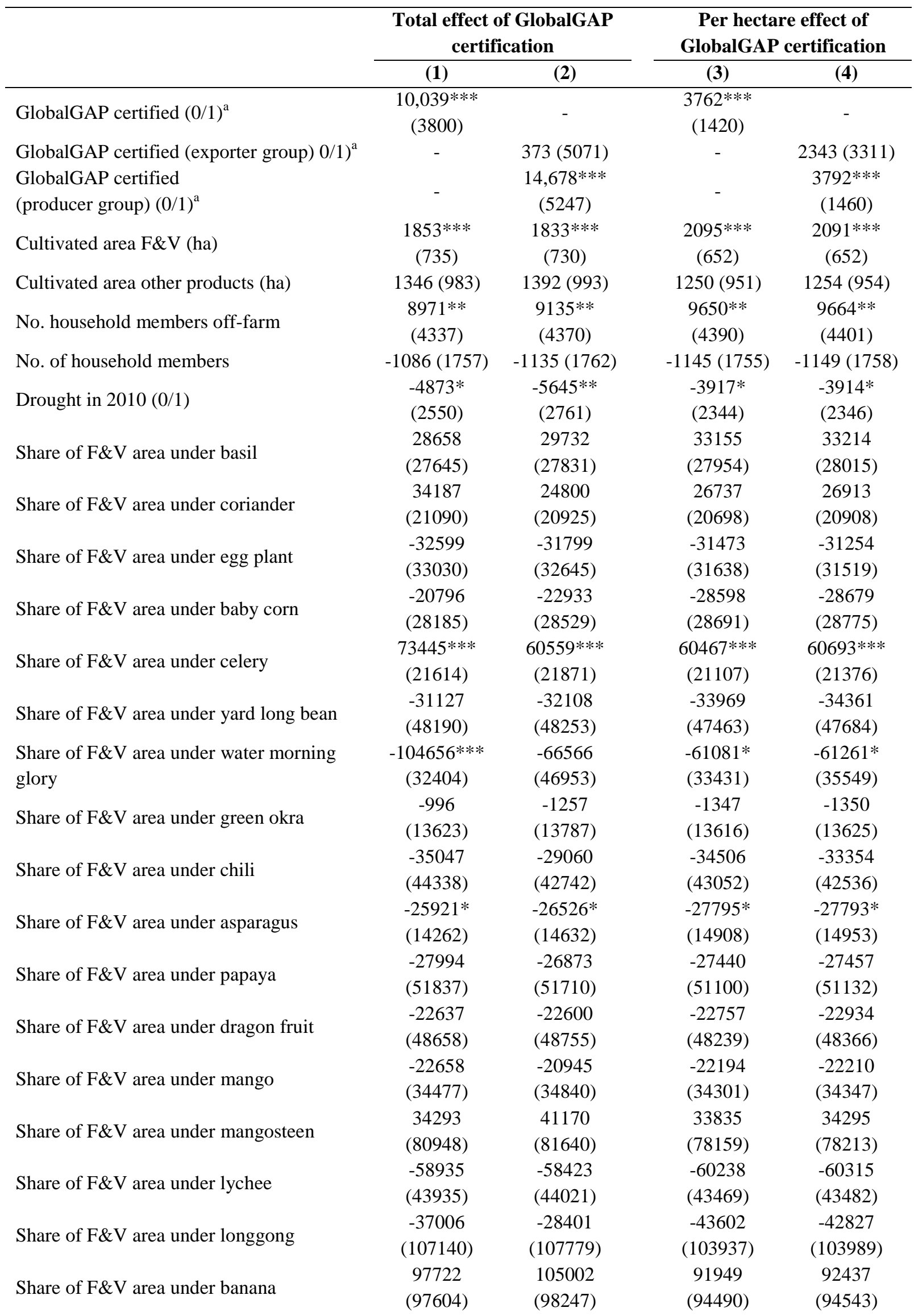


Share of F\&V area under durian

Share of $F \& V$ area under guava

Share of F\&V area under rambutan

Share of F\&V area under coconut

Share of F\&V area under longan

Share of F\&V area under fingerroot

Share of F\&V area under marian plum

Share of F\&V area under acacia penata

Share of F\&V area under santol tropical

Share of F\&V area under cucumber

Share of F\&V area under gourd

Share of F\&V area under melons

Share of F\&V area under other fruits ${ }^{b}$

Share of F\&V area under other vegetables ${ }^{c}$

Share of cultivated area with crops (except

F\&V) under maize

Share of cultivated area with crops (except

F\&V) under cassava

Share of cultivated area with crops (except

F\&V) under para rubber

Share of cultivated area with crops (except

F\&V) under oil palm

Share of cultivated area with crops (except

$\mathrm{F} \& \mathrm{~V}$ ) under sugar cane

Share of cultivated area with crops (except

$\mathrm{F} \& \mathrm{~V}$ ) under coffee

Share of cultivated area with crops (except

F\&V) under betel nut

Share of cultivated area with crops (except

F\&V) under other products ${ }^{\mathrm{d}}$

Constant

\section{3}

(88255)

$-2573$

(22645)

$-78831$

(111350)

$-89827$

(99862)

-87090**

(44832)

54638*

(30661)

5325

(56392)

49782'

(91588)

-183098*

(103371)

$-35534$

(46833)

40970

(139767)

20508

(50421)

18801

(77238)

$-53855$

(50849)

10943

(9878)

5532

(8441)

$-26182$

(19317)

$-18092$

(15144)

1891*

(1116)

16213

(15529)

106366

(71734)

23748

(29444)

20,675

$(35,083)$
65896

(88883)

2291

(21406)

$-74103$

(112928)

$-87134$

(102472)

-87219**

(44924)

55602*

(30740)

7666

(56960)

48709

(91847)

-180344*

(103383)

$-34773$

(46919)

66453

(141108)

22342

(49305)

26211

(77995)

$-53697$

(51003)

10215

(9723)

5229

(8475)

$-25947$

(19333)

$-18523$

(15125)

1821*

(1106)

15952

(15344)

107757

(72390)

29639

(28678)

19,275

$(35,472)$
58085

(85501)

$-3780$

(23188)

$-87743$

(110708)

$-106380$

(101335)

$-87749 * *$

(44176)

58671*

(31684)

7357

(56959)

48448

(90891)

-204747**

(99371)

$-37080$

(46375)

51350

(134961)

$-1894$

(46559)

23413

(74570)

$-56017$

(50046)

10972

(9286)

5649

(8501)

$-27266$

(18690)

$-16923$

(14731)

1830*

(1060)

16621

(15324)

113649

(72721)

24916

(28807)

20,821

58542

(85555)

$-2038$

(22336)

$-87551$

(110878)

$-106321$

(101675)

$-87818^{* *}$

(44209)

58818*

(31781)

7389

(57048)

49052

(91154)

-205212**

(99731)

$-37286$

(46514)

55906

(137888)

$-2174$

(46675)

24004

(74670)

$-56259$

(50119)

10904

(9264)

5603

(8526)

$-27047$

(18789)

$-16998$

(14759)

1827*

(1062)

16581

(15317)

113803

(72926)

26097

(28765)

20788

$(34,432)$

(34413)

428

428

0.16

0.16

428

428

R-squared

0.50

0.50

0.17

0.17

0.46

0.45

Notes: The dependent variable is net household income in USD. Statistical significance at the $1 \%(* * *), 5 \%(* *)$ and $10 \%(*)$ levels. Coefficient estimates are shown with cluster robust standard errors in parentheses. ${ }^{a}$ The reference group is non-certified farmers. ${ }^{b}$ Lemon, rose apple, salacca, grape. ${ }^{\mathrm{c}}$ Lemon grass, garlic chives, pigeon pea, pumpkin, wild betel leaf, spinach, tomato, Chinese kale, red leaf lettuce, parkia speciosa, houttuynia.

${ }^{\mathrm{d}}$ Included are atrium flower, jasmine flower, orchid, bamboo, eucalyptus. Source: Own data 
Table A8: Impact of certification on net household income (USD) (full model)

\begin{tabular}{|c|c|c|c|c|c|c|}
\hline & \multicolumn{3}{|c|}{$\begin{array}{c}\text { Scenario 1: } \\
\text { Net household income }\end{array}$} & \multicolumn{3}{|c|}{$\begin{array}{c}\text { Scenario 2: } \\
\text { Net household income } \\
\text { - recurrent costs }\end{array}$} \\
\hline & (1) & (2) & (3) & (4) & (5) & (6) \\
\hline GlobalGAP $(0 / 1)^{\mathrm{a}}$ & $\begin{array}{c}10,039 * * * \\
(3800)\end{array}$ & - & - & $\begin{array}{l}9478^{* * *} \\
(3791)\end{array}$ & - & - \\
\hline $\begin{array}{l}\text { GlobalGAP } \\
\text { (exporter group) }(0 / 1)^{\mathrm{a}}\end{array}$ & - & $\begin{array}{c}373 \\
(5071)\end{array}$ & - & - & $264(5071)$ & - \\
\hline $\begin{array}{l}\text { GlobalGAP } \\
\text { (producer group) }(0 / 1)^{\mathrm{a}}\end{array}$ & - & $\begin{array}{l}14,678^{* * *} \\
(5247)\end{array}$ & - & - & $\begin{array}{l}13,900^{* * *} \\
(5247)\end{array}$ & - \\
\hline $\begin{array}{l}\text { GlobalGAP (smallest } 75 \% \text { in } \\
\text { exporter group }(0 / 1)^{\text {ab }}\end{array}$ & - & (- & $\begin{array}{l}-3963 \\
(5460)\end{array}$ & - & (- & $\begin{array}{l}-4072 \\
(5460)\end{array}$ \\
\hline $\begin{array}{l}\text { GlobalGAP (largest } 25 \% \text { in } \\
\text { exporter group }(0 / 1)^{\text {ac }}\end{array}$ & - & - & $\begin{array}{c}16,451 \\
(12,176)\end{array}$ & - & - & $\begin{array}{c}16,342 \\
(12,176)\end{array}$ \\
\hline $\begin{array}{l}\text { GlobalGAP (smallest } 75 \% \text { in } \\
\text { producer group }(0 / 1)^{\mathrm{ab}}\end{array}$ & - & - & $\begin{array}{l}4465^{*} \\
(2732)\end{array}$ & - & - & 3687 (2732) \\
\hline $\begin{array}{l}\text { GlobalGAP (largest } 25 \% \text { in } \\
\text { producer group }(0 / 1)^{\text {ac }}\end{array}$ & - & - & $\begin{array}{c}37,732 * * * \\
(13,135)\end{array}$ & - & - & $\begin{array}{c}36,954^{* * *} \\
(13,135)\end{array}$ \\
\hline Cultivated area F\&V (ha) & $\begin{array}{c}1853^{* * *} \\
(735)\end{array}$ & $\begin{array}{c}1833^{* * *} \\
(730)\end{array}$ & $\begin{array}{c}1948^{* * *} \\
(694)\end{array}$ & $\begin{array}{c}1852^{* * *} \\
(734)\end{array}$ & $\begin{array}{c}1833^{* * *} \\
(730)\end{array}$ & $\begin{array}{l}1948^{* * *} \\
(694)\end{array}$ \\
\hline Cultivated area other products (ha) & $\begin{array}{l}1346 \\
(983)\end{array}$ & 1392 (993) & 1412 (998) & $\begin{array}{l}1348 \\
(983)\end{array}$ & 1392 (993) & 1412 (998) \\
\hline No. household members off-farm & $\begin{array}{l}8971^{* *} \\
(4337)\end{array}$ & $\begin{array}{l}9135 * * \\
(4370)\end{array}$ & $\begin{array}{l}9646 * * \\
(4447)\end{array}$ & $\begin{array}{l}8979 * * \\
(4337)\end{array}$ & $\begin{array}{l}9135 * * \\
(4370)\end{array}$ & $\begin{array}{c}9646 * * \\
(4447)\end{array}$ \\
\hline No. of household members & $\begin{array}{l}-1086 \\
(1757)\end{array}$ & $\begin{array}{l}-1135 \\
(1762)\end{array}$ & $\begin{array}{l}-1052 \\
(1760)\end{array}$ & $\begin{array}{l}-1088 * \\
(1757)\end{array}$ & $\begin{array}{l}-1135 \\
(1762)\end{array}$ & $\begin{array}{l}-1052 \\
(1760)\end{array}$ \\
\hline Drought $(0 / 1)$ & $\begin{array}{l}-4873^{*} \\
(2550)\end{array}$ & $\begin{array}{l}-5645^{* *} \\
(2761)\end{array}$ & $\begin{array}{l}-4939 * \\
(2649)\end{array}$ & $\begin{array}{l}-4909 \\
(2551)\end{array}$ & $\begin{array}{l}-5645 * * \\
(2761)\end{array}$ & $\begin{array}{l}-4939 * \\
(2649)\end{array}$ \\
\hline Share of F\&V area under basil & $\begin{array}{l}28658 \\
(27645)\end{array}$ & $\begin{array}{c}29732 \\
(27831)\end{array}$ & $\begin{array}{l}32914 \\
(28249)\end{array}$ & $\begin{array}{l}28658 \\
(27645)\end{array}$ & $\begin{array}{c}29732 \\
(27831)\end{array}$ & $\begin{array}{l}32914 \\
(28249)\end{array}$ \\
\hline Share of F\&V area under coriander & $\begin{array}{l}34187 \\
(21090)\end{array}$ & $\begin{array}{l}24800 \\
(20925)\end{array}$ & $\begin{array}{c}20395 \\
(20839)\end{array}$ & $\begin{array}{c}34187 \\
(21090)\end{array}$ & $\begin{array}{l}24800 \\
(20925)\end{array}$ & $\begin{array}{c}20395 \\
(20839)\end{array}$ \\
\hline Share of F\&V area under egg plant & $\begin{array}{l}-32599 \\
(33030)\end{array}$ & $\begin{array}{l}-31799 \\
(32645)\end{array}$ & $\begin{array}{l}-30288 \\
(31741)\end{array}$ & $\begin{array}{l}-32599 \\
(33030)\end{array}$ & $\begin{array}{l}-31799 \\
(32645)\end{array}$ & $\begin{array}{l}-30288 \\
(31741)\end{array}$ \\
\hline Share of F\&V area under baby corn & $\begin{array}{l}-20796 \\
(28185)\end{array}$ & $\begin{array}{l}-22933 \\
(28529)\end{array}$ & $\begin{array}{l}-32528 \\
(30484)\end{array}$ & $\begin{array}{l}-20796 \\
(28185)\end{array}$ & $\begin{array}{l}-22933 \\
(28529)\end{array}$ & $\begin{array}{l}-32528 \\
(30484)\end{array}$ \\
\hline Share of F\&V area under celery & $\begin{array}{c}73445 * * * \\
(21614)\end{array}$ & $\begin{array}{c}60559 * * * \\
(21871)\end{array}$ & $\begin{array}{l}51677^{* *} \\
(21615)\end{array}$ & $\begin{array}{l}73445^{* * *} \\
(21614)\end{array}$ & $\begin{array}{c}60559 * * * \\
(21871)\end{array}$ & $\begin{array}{r}51677^{* *} \\
(21615)\end{array}$ \\
\hline $\begin{array}{l}\text { Share of F\&V area under yard long } \\
\text { bean }\end{array}$ & $\begin{array}{l}-31127 \\
(48190)\end{array}$ & $\begin{array}{l}-32108 \\
(48253)\end{array}$ & $\begin{array}{l}-33518 \\
(48437)\end{array}$ & $\begin{array}{l}-31127 \\
(48190)\end{array}$ & $\begin{array}{l}-32108 \\
(48253)\end{array}$ & $\begin{array}{l}-33518 \\
(48437)\end{array}$ \\
\hline $\begin{array}{l}\text { Share of F\&V area under water } \\
\text { morning glory }\end{array}$ & $\begin{array}{c}-104656 * * * \\
(32404)\end{array}$ & $\begin{array}{l}-66566 \\
(46953)\end{array}$ & $\begin{array}{l}-29207 \\
(46315)\end{array}$ & $\begin{array}{c}-104656 * * * \\
(32404)\end{array}$ & $\begin{array}{l}-66566 \\
(46953)\end{array}$ & $\begin{array}{l}-29207 \\
(46315)\end{array}$ \\
\hline $\begin{array}{l}\text { Share of F\&V area under green } \\
\text { okra }\end{array}$ & $\begin{array}{c}-996 \\
(13623)\end{array}$ & $\begin{array}{l}-1257 \\
(13787)\end{array}$ & $\begin{array}{c}-1213 \\
(13923)\end{array}$ & $\begin{array}{c}-996 \\
(13623)\end{array}$ & $\begin{array}{l}-1257 \\
(13787)\end{array}$ & $\begin{array}{c}-1213 \\
(13923)\end{array}$ \\
\hline Share of F\&V area under chili & $\begin{array}{l}-35047 \\
(44338)\end{array}$ & $\begin{array}{l}-29060 \\
(42742)\end{array}$ & $\begin{array}{l}-29034 \\
(42838)\end{array}$ & $\begin{array}{l}-35047 \\
(44338)\end{array}$ & $\begin{array}{l}-29060 \\
(42742)\end{array}$ & $\begin{array}{c}-29034 \\
(42838)\end{array}$ \\
\hline Share of $F \& V$ area under asparagus & $\begin{array}{c}-25921^{*} \\
(14262)\end{array}$ & $\begin{array}{c}-26526^{*} \\
(14632)\end{array}$ & $\begin{array}{l}-28426^{*} \\
(15389)\end{array}$ & $\begin{array}{l}-25921^{*} \\
(14262)\end{array}$ & $\begin{array}{c}-26526^{*} \\
(14632)\end{array}$ & $\begin{array}{c}-28426^{*} \\
(15389)\end{array}$ \\
\hline Share of F\&V area under papaya & $\begin{array}{l}-27994 \\
(51837)\end{array}$ & $\begin{array}{c}-26873 \\
(51710)\end{array}$ & $\begin{array}{l}-26119 \\
(51755)\end{array}$ & $\begin{array}{c}-27994 \\
(51837)\end{array}$ & $\begin{array}{l}-26873 \\
(51710)\end{array}$ & $\begin{array}{l}-26119 \\
(51755)\end{array}$ \\
\hline
\end{tabular}


Share of F\&V area under dragon fruit

Share of F\&V area under mango

Share of F\&V area under

mangosteen

Share of F\&V area under lychee

Share of F\&V area under longgong

Share of F\&V area under banana

Share of F\&V area under durian

Share of F\&V area under guava

Share of F\&V area under rambutan

Share of F\&V area under coconut

Share of F\&V area under longan

Share of F\&V area under

fingerroot

Share of F\&V area under marian

plum

Share of F\&V area under acacia piñata

Share of F\&V area under santol tropical

Share of F\&V area under cucumber

Share of F\&V area under gourd

Share of F\&V area under melons

Share of F\&V area under other fruits $^{\mathrm{d}}$

Share of F\&V area under other vegetables $^{\mathrm{e}}$

Share of cultivated area with crops (except F\&V) under maize

Share of cultivated area with crops (except F\&V) under cassava

Share of cultivated area with crops (except F\&V) under para rubber

Share of cultivated area with crops (except F\&V) under oil palm

Share of cultivated area with crops (except F\&V) under sugar cane Share of cultivated area with crops (except F\&V) under coffee

\begin{tabular}{|c|c|c|c|c|c|}
\hline $\begin{array}{l}-22637 \\
(48658)\end{array}$ & $\begin{array}{l}-22600 \\
(48755)\end{array}$ & $\begin{array}{l}-22035 \\
(49080)\end{array}$ & $\begin{array}{l}-22637 \\
(48658)\end{array}$ & $\begin{array}{l}-22600 \\
(48755)\end{array}$ & $\begin{array}{l}-22035 \\
(49080)\end{array}$ \\
\hline-22658 & -20945 & -19928 & -22658 & -20945 & -19928 \\
\hline (34477) & (34840) & (35118) & (34477) & (34840) & (35118) \\
\hline 34293 & 41170 & 41834 & 34293 & 41170 & 41834 \\
\hline (80948) & (81640) & (81661) & (80948) & (81640) & (81661) \\
\hline-58935 & -58423 & -58798 & -58935 & -58423 & -58798 \\
\hline (43935) & (44021) & (44214) & (43935) & (44021) & (44214) \\
\hline-37006 & -28401 & -29697 & -37006 & -28401 & -29697 \\
\hline (107140) & (107779) & (107663) & (107140) & (107779) & (107663) \\
\hline 97722 & 105002 & 104704 & 97722 & 105002 & 104704 \\
\hline (97604) & (98247) & (98117) & (97604) & (98247) & (98117) \\
\hline 59013 & 65896 & 66940 & 59013 & 65896 & 66940 \\
\hline (88255) & (88883) & (88803) & (88255) & (88883) & (88803) \\
\hline-2573 & 2291 & -855 & -2573 & 2291 & -855 \\
\hline (22645) & (21406) & (22489) & (22645) & (21406) & (22489) \\
\hline-78831 & -74103 & -74010 & -78831 & -74103 & -74010 \\
\hline (111350) & (112928) & (113680) & (111350) & (112928) & (113680) \\
\hline-89827 & -87134 & -95689 & -89827 & -87134 & -95689 \\
\hline (99862) & (102472) & (104400) & (99862) & (102472) & (104400) \\
\hline$-87090 * *$ & $-87219 * *$ & $-85693^{*}$ & $-87090 * *$ & $-87219 * *$ & -85693* \\
\hline (44832) & (44924) & (44933) & (44832) & (44924) & (44933) \\
\hline $54638 *$ & $55602 *$ & 60018* & 54638* & $55602 *$ & 60018* \\
\hline (30661) & (30740) & (31398) & (30661) & (30740) & (31398) \\
\hline 5325 & 7666 & 9757 & 5325 & 7666 & 9757 \\
\hline (56392) & (56960) & (57577) & (56392) & (56960) & (57577) \\
\hline $49782^{\prime}$ & 48709 & 44494 & $49782^{\prime}$ & 48709 & 44494 \\
\hline (91588) & (91847) & (92504) & (91588) & (91847) & (92504) \\
\hline -183098* & $-180344^{*}$ & $-196562 * *$ & $-183098 *$ & $-180344^{*}$ & $-196562 * *$ \\
\hline (103371) & (103383) & $(99745)$ & (103371) & (103383) & (99745) \\
\hline-35534 & -34773 & -35838 & -35534 & -34773 & -35838 \\
\hline (46833) & (46919) & (47230) & (46833) & (46919) & (47230) \\
\hline 40970 & 66453 & 75108 & 40970 & 66453 & 75108 \\
\hline (139767) & (141108) & (141801) & (139767) & (141108) & (141801) \\
\hline 20508 & 22342 & 16323 & 20508 & 22342 & 16323 \\
\hline (50421) & (49305) & (48566) & (50421) & (49305) & (48566) \\
\hline 18801 & 26211 & 28864 & 18801 & 26211 & 28864 \\
\hline (77238) & (77995) & (77900) & (77238) & (77995) & (77900) \\
\hline-53855 & -53697 & -54334 & -53855 & -53697 & -54334 \\
\hline (50849) & (51003) & (51089) & (50849) & (51003) & (51089) \\
\hline 10943 & 10215 & 10449 & 10943 & 10215 & 10449 \\
\hline (9878) & (9723) & (9353) & (9878) & (9723) & (9353) \\
\hline 5532 & 5229 & 4899 & 5532 & 5229 & 4899 \\
\hline (8441) & (8475) & (8585) & (8441) & (8475) & (8585) \\
\hline-26182 & -25947 & -28475 & -26182 & -25947 & -28475 \\
\hline (19317) & (19333) & (18951) & (19317) & (19333) & (18951) \\
\hline-18092 & -18523 & -17778 & -18092 & -18523 & -17778 \\
\hline (15144) & (15125) & (14904) & (15144) & (15125) & (14904) \\
\hline $1891^{*}$ & $1821^{*}$ & 1737 & $1891^{*}$ & $1821 *$ & 1737 \\
\hline (1116) & (1106) & (1079) & (1116) & (1106) & (1079) \\
\hline 16213 & 15952 & 16224 & 16213 & 15952 & 16224 \\
\hline (15529) & (15344) & (15334) & (15529) & (15344) & (15334) \\
\hline
\end{tabular}




\begin{tabular}{|c|c|c|c|c|c|c|}
\hline $\begin{array}{l}\text { Share of cultivated area with crops } \\
\text { (except F\&V) under betel nut }\end{array}$ & $\begin{array}{l}106366 \\
(71734)\end{array}$ & $\begin{array}{l}107757 \\
(72390)\end{array}$ & $\begin{array}{l}109321 \\
(73107)\end{array}$ & $\begin{array}{l}106366 \\
(71734)\end{array}$ & $\begin{array}{l}107757 \\
(72390)\end{array}$ & $\begin{array}{l}109321 \\
(73107)\end{array}$ \\
\hline $\begin{array}{l}\text { Share of cultivated area with crops } \\
\text { (except F\&V) under products }{ }^{\mathrm{f}}\end{array}$ & $\begin{array}{c}23748 \\
(29444)\end{array}$ & $\begin{array}{c}29639 \\
(28678)\end{array}$ & $\begin{array}{c}30354 \\
(28465)\end{array}$ & $\begin{array}{c}23748 \\
(29444)\end{array}$ & $\begin{array}{c}29639 \\
(28678)\end{array}$ & $\begin{array}{c}30354 \\
(28465)\end{array}$ \\
\hline Constant & $\begin{array}{c}20,675 \\
(35,083)\end{array}$ & $\begin{array}{c}19,275 \\
(35,472)\end{array}$ & $\begin{array}{c}18,272 \\
(35,284)\end{array}$ & $\begin{array}{c}20,609 \\
(35,082)\end{array}$ & $\begin{array}{c}19,275 \\
(35,193)\end{array}$ & $\begin{array}{c}18,272 \\
(35,284)\end{array}$ \\
\hline Number of observations & 428 & 428 & 428 & 428 & 428 & 428 \\
\hline R-squared & 0.16 & 0.16 & 0.16 & 0.16 & 0.16 & 0.16 \\
\hline Hausman test & 0.50 & 0.50 & 0.47 & 0.50 & 0.50 & 0.47 \\
\hline
\end{tabular}

Notes: The dependent variable is net household income in USD. Coefficient estimates are shown with cluster robust standard errors in parentheses. Statistical significance at the 1\% (***), 5\% (**), and 10\% (*) levels.

${ }^{\mathrm{a}}$ The reference group is non-certified farmers.

${ }^{\mathrm{b}}$ Certified area ranges from 0.16 to 1.6 ha.

${ }^{c}$ Certified area ranges from 1.92 to 33.92 ha.

${ }^{\mathrm{d}}$ Included are lemon, rose apple, salacca, grape.

e Included are lemon grass, garlic chives, pigeon pea, pumpkin, wild betel leaf, spinach, tomato, Chinese kale, red leaf lettuce, parkia speciosa, houttuynia.

${ }^{\mathrm{f}}$ Included are atrium flower, jasmine flower, orchid, bamboo, eucalyptus.

Source: Own data 
Table A9: Impact of certification on net household income (USD) (full model)

\begin{tabular}{|c|c|c|c|c|}
\hline & \multicolumn{2}{|c|}{$\begin{array}{c}\text { Scenario 1: } \\
\text { Net household income }\end{array}$} & \multicolumn{2}{|c|}{$\begin{array}{c}\text { Scenario 2: } \\
\text { Net household income } \\
\text { - recurrent costs }\end{array}$} \\
\hline & $(1)$ & (2) & (1) & $(2)$ \\
\hline GlobalGAP (smallest $85 \%^{\mathrm{b}}$ in exporter group $(0 / 1)^{\mathrm{a}}$ & $\begin{array}{c}-491 \\
(5625)\end{array}$ & - & $\begin{array}{c}-600 \\
(5625)\end{array}$ & - \\
\hline GlobalGAP (largest $15 \%{ }^{\mathrm{c}}$ in exporter group $(0 / 1)^{\mathrm{a}}$ & $\begin{array}{c}6637 \\
(9662)\end{array}$ & - & $\begin{array}{c}6528 \\
(9662)\end{array}$ & - \\
\hline GlobalGAP (smallest $85 \%{ }^{\mathrm{b}}$ in producer group $(0 / 1)^{\mathrm{a}}$ & $\begin{array}{l}5570^{*} \\
(2892)\end{array}$ & - & $\begin{array}{l}4792^{*} \\
(2892)\end{array}$ & - \\
\hline GlobalGAP (largest $15 \%^{\mathrm{c}}$ in producer group $(0 / 1)^{\mathrm{a}}$ & $\begin{array}{c}53,577^{* * *} \\
(18,018)\end{array}$ & - & $\begin{array}{c}52,799 * * * \\
(18,018)\end{array}$ & - \\
\hline GlobalGAP (smallest $65 \%{ }^{\mathrm{d}}$ in exporter group $(0 / 1)^{\mathrm{a}}$ & - & $\begin{array}{l}-3218 \\
(5771)\end{array}$ & - & $\begin{array}{l}-3327 \\
(5771)\end{array}$ \\
\hline GlobalGAP (largest $35 \%{ }^{\mathrm{e}}$ in exporter group $(0 / 1)^{\mathrm{a}}$ & - & $\begin{array}{c}9756 \\
(10,388)\end{array}$ & - & $\begin{array}{c}9647 \\
(10,388)\end{array}$ \\
\hline GlobalGAP (smallest $65 \%{ }^{\mathrm{d}}$ in producer group $(0 / 1)^{\mathrm{a}}$ & - & $\begin{array}{c}2690 \\
(2803)\end{array}$ & - & $\begin{array}{c}1912 \\
(2803)\end{array}$ \\
\hline GlobalGAP (largest $35 \%^{\mathrm{e}}$ in producer group $(0 / 1)^{\mathrm{a}}$ & - & $\begin{array}{c}31,900 * * * \\
(10,077)\end{array}$ & - & $\begin{array}{c}31,122^{* * *} \\
(10,077)\end{array}$ \\
\hline Cultivated area F\&V (ha) & $\begin{array}{c}1945^{* * *} \\
(676)\end{array}$ & $\begin{array}{c}1944 * * * \\
(703)\end{array}$ & $\begin{array}{c}1945^{* * *} \\
(676)\end{array}$ & $\begin{array}{c}1944 * * * \\
(703)\end{array}$ \\
\hline Cultivated area other products (ha) & $\begin{array}{l}1352 \\
(982)\end{array}$ & $\begin{array}{l}1351 \\
(992)\end{array}$ & $\begin{array}{l}1352 \\
(982)\end{array}$ & $\begin{array}{l}1351 \\
(992)\end{array}$ \\
\hline No. household members off-farm & $\begin{array}{l}9601^{* *} \\
(4425)\end{array}$ & $\begin{array}{l}9434^{* *} \\
(4395)\end{array}$ & $\begin{array}{l}9601^{* *} \\
(4425)\end{array}$ & $\begin{array}{l}9434^{* *} \\
(4395)\end{array}$ \\
\hline No. of household members & $\begin{array}{l}-1084 \\
(1763)\end{array}$ & $\begin{array}{l}-1134 \\
(1764)\end{array}$ & $\begin{array}{l}-1084 \\
(1763)\end{array}$ & $\begin{array}{l}-1134 \\
(1764)\end{array}$ \\
\hline Drought in $2010(0 / 1)$ & $\begin{array}{l}-4614^{*} \\
(2634)\end{array}$ & $\begin{array}{l}-4916^{*} \\
(2661)\end{array}$ & $\begin{array}{l}-4614^{*} \\
(2634)\end{array}$ & $\begin{array}{l}-4916^{*} \\
(2661)\end{array}$ \\
\hline Share of F\&V area under basil & $\begin{array}{l}32624 \\
(28139)\end{array}$ & $\begin{array}{c}32624 \\
(28139)\end{array}$ & $\begin{array}{c}31842 \\
(27988)\end{array}$ & $\begin{array}{c}31842 \\
(27988)\end{array}$ \\
\hline Share of F\&V area under coriander & $\begin{array}{l}25161 \\
(21250)\end{array}$ & $\begin{array}{c}25161 \\
(21250)\end{array}$ & $\begin{array}{l}21273 \\
(21459)\end{array}$ & $\begin{array}{l}21273 \\
(21459)\end{array}$ \\
\hline Share of F\&V area under egg plant & $\begin{array}{c}-30971 \\
(32051)\end{array}$ & $\begin{array}{l}-30971 \\
(32051)\end{array}$ & $\begin{array}{l}-31730 \\
(32282)\end{array}$ & $\begin{array}{l}-31730 \\
(32282)\end{array}$ \\
\hline Share of F\&V area under baby corn & $\begin{array}{l}-29755 \\
(28865)\end{array}$ & $\begin{array}{l}-29755 \\
(28865)\end{array}$ & $\begin{array}{l}-31100 \\
(29946)\end{array}$ & $\begin{array}{l}-31100 \\
(29946)\end{array}$ \\
\hline Share of F\&V area under celery & $\begin{array}{c}58711^{* * *} \\
(22223)\end{array}$ & $\begin{array}{c}58711^{* * *} \\
(22223)\end{array}$ & $\begin{array}{l}53701^{* *} \\
(22632)\end{array}$ & $\begin{array}{l}53701^{* *} \\
(22632)\end{array}$ \\
\hline Share of F\&V area under yard long bean & $\begin{array}{l}-33382 \\
(48210)\end{array}$ & $\begin{array}{l}-33382 \\
(48210)\end{array}$ & $\begin{array}{l}-32879 \\
(48368)\end{array}$ & $\begin{array}{l}-32879 \\
(48368)\end{array}$ \\
\hline Share of F\&V area under water morning glory & $\begin{array}{l}-54359 \\
(45203)\end{array}$ & $\begin{array}{l}-54359 \\
(45203)\end{array}$ & $\begin{array}{l}-39261 \\
(47788)\end{array}$ & $\begin{array}{l}-39261 \\
(47788)\end{array}$ \\
\hline Share of F\&V area under green okra & $\begin{array}{c}-1200 \\
(13820)\end{array}$ & $\begin{array}{c}-1200 \\
(13820)\end{array}$ & $\begin{array}{c}-1303 \\
(13804)\end{array}$ & $\begin{array}{c}-1303 \\
(13804)\end{array}$ \\
\hline Share of F\&V area under chili & $\begin{array}{c}-30726 \\
(42955)\end{array}$ & $\begin{array}{c}-30726 \\
(42955)\end{array}$ & $\begin{array}{c}-32146 \\
(42591)\end{array}$ & $\begin{array}{c}-32146 \\
(42591)\end{array}$ \\
\hline Share of $F \& V$ area under asparagus & $\begin{array}{c}-27933^{*} \\
(15085)\end{array}$ & $\begin{array}{l}-27933^{*} \\
(15085)\end{array}$ & $\begin{array}{l}-28353^{*} \\
(15196)\end{array}$ & $\begin{array}{l}-28353^{*} \\
(15196)\end{array}$ \\
\hline
\end{tabular}


Appendices

\begin{tabular}{|c|c|c|c|c|}
\hline Share of F\&V area under papaya & $\begin{array}{l}-26902 \\
(51748)\end{array}$ & $\begin{array}{l}-26902 \\
(51748)\end{array}$ & $\begin{array}{l}-25883 \\
(51663)\end{array}$ & $\begin{array}{l}-25883 \\
(51663)\end{array}$ \\
\hline Share of $F \& V$ area under dragon fruit & $\begin{array}{l}-22414 \\
(48920)\end{array}$ & $\begin{array}{l}-22414 \\
(48920)\end{array}$ & $\begin{array}{l}-21607 \\
(49034)\end{array}$ & $\begin{array}{l}-21607 \\
(49034)\end{array}$ \\
\hline Share of $F \& V$ area under mango & $\begin{array}{l}-21478 \\
(34828)\end{array}$ & $\begin{array}{l}-21478 \\
(34828)\end{array}$ & $\begin{array}{l}-21073 \\
(35104)\end{array}$ & $\begin{array}{l}-21073 \\
(35104)\end{array}$ \\
\hline Share of F\&V area under mangosteen & $\begin{array}{c}38194 \\
(81233)\end{array}$ & $\begin{array}{c}38194 \\
(81233)\end{array}$ & $\begin{array}{c}43722 \\
(82708)\end{array}$ & $\begin{array}{c}43722 \\
(82708)\end{array}$ \\
\hline Share of F\&V area under lychee & $\begin{array}{c}-58768 \\
(44067)\end{array}$ & $\begin{array}{l}-58768 \\
(44067)\end{array}$ & $\begin{array}{l}-58830 \\
(44229)\end{array}$ & $\begin{array}{l}-58830 \\
(44229)\end{array}$ \\
\hline Share of F\&V area under longgong & $\begin{array}{c}-33965 \\
(107025)\end{array}$ & $\begin{array}{c}-33965 \\
(107025)\end{array}$ & $\begin{array}{c}-30108 \\
(108792)\end{array}$ & $\begin{array}{c}-30108 \\
(108792)\end{array}$ \\
\hline Share of $F \& V$ area under banana & $\begin{array}{c}99900 \\
(97527)\end{array}$ & $\begin{array}{c}99900 \\
(97527)\end{array}$ & $\begin{array}{l}106016 \\
(99314)\end{array}$ & $\begin{array}{c}106016 \\
(99314)\end{array}$ \\
\hline Share of F\&V area under durian & $\begin{array}{c}62993 \\
(88407)\end{array}$ & $\begin{array}{c}62993 \\
(88407)\end{array}$ & $\begin{array}{c}68349 \\
(89912)\end{array}$ & $\begin{array}{c}68349 \\
(89912)\end{array}$ \\
\hline Share of F\&V area under guava & $\begin{array}{c}14 \\
(22081)\end{array}$ & $\begin{array}{c}14 \\
(22081)\end{array}$ & $\begin{array}{c}-2305 \\
(22726)\end{array}$ & $\begin{array}{c}-2305 \\
(22726)\end{array}$ \\
\hline Share of F\&V area under rambutan & $\begin{array}{c}-78989 \\
(112311)\end{array}$ & $\begin{array}{c}-78989 \\
(112311)\end{array}$ & $\begin{array}{c}-74350 \\
(114618)\end{array}$ & $\begin{array}{c}-74350 \\
(114618)\end{array}$ \\
\hline Share of F\&V area under coconut & $\begin{array}{c}-95362 \\
(102116)\end{array}$ & $\begin{array}{c}-95362 \\
(102116)\end{array}$ & $\begin{array}{c}-93131 \\
(104718)\end{array}$ & $\begin{array}{c}-93131 \\
(104718)\end{array}$ \\
\hline Share of $F \& V$ area under longan & $\begin{array}{c}-86807 * * \\
(44890)\end{array}$ & $\begin{array}{c}-86807 * * \\
(44890)\end{array}$ & $\begin{array}{c}-85518^{*} \\
(44885)\end{array}$ & $\begin{array}{c}-85518 * \\
(44885)\end{array}$ \\
\hline Share of F\&V area under fingerroot & $\begin{array}{l}58869 * \\
(31105)\end{array}$ & $\begin{array}{l}58869 * \\
(31105)\end{array}$ & $\begin{array}{l}59377 * \\
(31327)\end{array}$ & $\begin{array}{l}59377 * \\
(31327)\end{array}$ \\
\hline Share of F\&V area under marian plum & $\begin{array}{c}7642 \\
(57212)\end{array}$ & $\begin{array}{c}7642 \\
(57212)\end{array}$ & $\begin{array}{c}8435 \\
(57585)\end{array}$ & $\begin{array}{c}8435 \\
(57585)\end{array}$ \\
\hline Share of F\&V area under acacia penata & $\begin{array}{c}46625 \\
(92136)\end{array}$ & $\begin{array}{c}46625 \\
(92136)\end{array}$ & $\begin{array}{c}46856 \\
(92185)\end{array}$ & $\begin{array}{c}46856 \\
(92185)\end{array}$ \\
\hline Share of F\&V area under santol tropical & $\begin{array}{c}-191458 * \\
(101808)\end{array}$ & $\begin{array}{c}-191458 * \\
(101808)\end{array}$ & $\begin{array}{c}-190904 * \\
(100521)\end{array}$ & $\begin{array}{c}-190904 * \\
(100521)\end{array}$ \\
\hline Share of F\&V area under cucumber & $\begin{array}{l}-36199 \\
(47003)\end{array}$ & $\begin{array}{l}-36199 \\
(47003)\end{array}$ & $\begin{array}{l}-34926 \\
(47194)\end{array}$ & $\begin{array}{l}-34926 \\
(47194)\end{array}$ \\
\hline Share of F\&V area under gourd & $\begin{array}{c}66758 \\
(141016)\end{array}$ & $\begin{array}{c}66758 \\
(141016)\end{array}$ & $\begin{array}{c}72548 \\
8140219)\end{array}$ & $\begin{array}{c}72548 \\
8140219)\end{array}$ \\
\hline Share of F\&V area under melons & $\begin{array}{c}13057 \\
(47825)\end{array}$ & $\begin{array}{c}13057 \\
(47825)\end{array}$ & $\begin{array}{c}17433 \\
(48919)\end{array}$ & $\begin{array}{c}17433 \\
(48919)\end{array}$ \\
\hline Share of F\&V area under other fruits ${ }^{\mathrm{f}}$ & $\begin{array}{c}26084 \\
(77707)\end{array}$ & $\begin{array}{c}26084 \\
(77707)\end{array}$ & $\begin{array}{c}29548 \\
(78853)\end{array}$ & $\begin{array}{c}29548 \\
(78853)\end{array}$ \\
\hline Share of F\&V area under other vegetables ${ }^{g}$ & $\begin{array}{c}-54678 \\
(50861)\end{array}$ & $\begin{array}{l}-54678 \\
(50861)\end{array}$ & $\begin{array}{l}-54311 \\
(51122)\end{array}$ & $\begin{array}{l}-54311 \\
(51122)\end{array}$ \\
\hline $\begin{array}{l}\text { Share of cultivated area with crops (except F\&V) } \\
\text { under maize }\end{array}$ & $\begin{array}{l}10734 \\
(9436)\end{array}$ & $\begin{array}{l}10734 \\
(9436)\end{array}$ & $\begin{array}{l}10531 \\
(9471)\end{array}$ & $\begin{array}{l}10531 \\
(9471)\end{array}$ \\
\hline $\begin{array}{l}\text { Share of cultivated area with crops (except F\&V) } \\
\text { under cassava }\end{array}$ & $\begin{array}{c}5134 \\
(8551)\end{array}$ & $\begin{array}{c}5134 \\
(8551)\end{array}$ & $\begin{array}{c}5307 \\
(8529)\end{array}$ & $\begin{array}{c}5307 \\
(8529)\end{array}$ \\
\hline $\begin{array}{l}\text { Share of cultivated area with crops (except F\&V) } \\
\text { under para rubber }\end{array}$ & $\begin{array}{l}-26123 \\
(19184)\end{array}$ & $\begin{array}{l}-26123 \\
(19184)\end{array}$ & $\begin{array}{l}-29011 \\
(18853)\end{array}$ & $\begin{array}{l}-29011 \\
(18853)\end{array}$ \\
\hline $\begin{array}{l}\text { Share of cultivated area with crops (except F\&V) } \\
\text { under oil palm }\end{array}$ & $\begin{array}{l}-17927 \\
(14920)\end{array}$ & $\begin{array}{l}-17927 \\
(14920)\end{array}$ & $\begin{array}{l}-17462 \\
(15082)\end{array}$ & $\begin{array}{l}-17462 \\
(15082)\end{array}$ \\
\hline $\begin{array}{l}\text { Share of cultivated area with crops (except F\&V) } \\
\text { under sugar cane }\end{array}$ & $\begin{array}{c}1682 \\
(1064)\end{array}$ & $\begin{array}{c}1682 \\
(1064)\end{array}$ & $\begin{array}{c}1688 \\
(1074)\end{array}$ & $\begin{array}{c}1688 \\
(1074)\end{array}$ \\
\hline
\end{tabular}


Appendices

\begin{tabular}{|c|c|c|c|c|}
\hline $\begin{array}{l}\text { Share of cultivated area with crops (except F\&V) } \\
\text { under coffee }\end{array}$ & $\begin{array}{c}16269 \\
(15318)\end{array}$ & $\begin{array}{c}16269 \\
(15318)\end{array}$ & $\begin{array}{c}16475 \\
(15486)\end{array}$ & $\begin{array}{c}16475 \\
(15486)\end{array}$ \\
\hline Share of cultivated area with crops (except F\&V) & 109493 & 109493 & 111154 & 111154 \\
\hline $\begin{array}{l}\text { under betel nut } \\
\text { Share of cultivated area with crops (except F\&V) }\end{array}$ & $\begin{array}{l}(72565) \\
28640\end{array}$ & $\begin{array}{l}(72565) \\
28640\end{array}$ & $\begin{array}{c}(73267) \\
23544\end{array}$ & $\begin{array}{c}(73267) \\
23544\end{array}$ \\
\hline under other products ${ }^{\mathrm{h}}$ & $\begin{array}{c}(28647) \\
19,292 \\
(35,148)\end{array}$ & $\begin{array}{c}(28647) \\
18,531 \\
(35,433)\end{array}$ & $\begin{array}{c}(29957) \\
19,292 \\
(35,148)\end{array}$ & $\begin{array}{c}(29957) \\
18,531 \\
(35,433)\end{array}$ \\
\hline Number of observations & 428 & 428 & 428 & 428 \\
\hline R-squared & 0.16 & 0.16 & 0.16 & 0.16 \\
\hline Hausman test & 0.47 & 0.47 & 0.47 & 0.47 \\
\hline
\end{tabular}

Statistical significance at the $1 \%(* * *), 5 \%(* *)$ and $10 \%(*)$ levels. Coefficient estimates are shown with cluster robust standard errors in parentheses.

${ }^{\mathrm{a}}$ The reference group is non-certified farmers.

${ }^{\mathrm{b}}$ Certified area ranges from $0.16-2.64 \mathrm{ha}$.

${ }^{\mathrm{c}}$ Certified area ranges from $3.16-33.92$ ha.

${ }^{\mathrm{d}}$ Certified area ranges from $0.16-1.44$ ha

${ }^{\mathrm{e}}$ Certified area ranges from 1.6 - 33.92 ha.

${ }^{\mathrm{f}}$ Included are lemon, rose apple, salacca, grape.

${ }^{\mathrm{g}}$ Included are lemon grass, garlic chives, pigeon pea, pumpkin, wild betel leaf, spinach, tomato, Chinese kale, red leaf lettuce, parkia speciosa, houttuynia.

${ }^{\mathrm{h}}$ Included are atrium flower, jasmine flower, orchid, bamboo, eucalyptus.

Source: Own data 


\section{Appendix IV: Bivariate probit model results}

Table A10: Bivariate probit model estimating GlobalGAP adoption in 2010 and continued compliance in 2011

\begin{tabular}{|c|c|c|c|}
\hline \multirow[b]{2}{*}{ Explanatory variables } & \multirow{2}{*}{$\begin{array}{c}\text { Adoption } \\
\text { (2010) } \\
\mathrm{N}=214 \\
\text { Coefficient }\end{array}$} & \multicolumn{2}{|c|}{$\begin{array}{c}\text { Re-certification } \\
\text { (2011) } \\
\mathrm{N}=72 \\
\end{array}$} \\
\hline & & Coefficient & Marginal effects \\
\hline Exporter support $(0 / 1)^{\mathrm{a}}$ & $\begin{array}{c}1.97 * * * \\
(0.36)\end{array}$ & $\begin{array}{c}2.48 * * * \\
(0.42)\end{array}$ & $\begin{array}{c}0.70 * * * \\
(0.11)\end{array}$ \\
\hline Donor support $(0 / 1)^{\mathrm{a}}$ & $\begin{array}{c}2.05 * * * \\
(0.33)\end{array}$ & $\begin{array}{c}0.10 \\
(0.09)\end{array}$ & - \\
\hline Number extension topics & $\begin{array}{c}0.16^{* * *} \\
(0.05)\end{array}$ & $\begin{array}{c}0.03 \\
(0.02)\end{array}$ & $\begin{array}{c}0.03 \\
(0.02)\end{array}$ \\
\hline Age of the household head & $\begin{array}{c}-0.04^{* *} \\
(0.02)\end{array}$ & $\begin{array}{l}-0.09 \\
(0.10)\end{array}$ & $\begin{array}{c}0.01 \\
(0.00)\end{array}$ \\
\hline Number of household members & $\begin{array}{c}0.13 \\
(0.09)\end{array}$ & $\begin{array}{c}0.73 \\
(0.46)\end{array}$ & $\begin{array}{l}-0.02 \\
(0.02)\end{array}$ \\
\hline College graduate $(0 / 1)$ & $\begin{array}{c}0.91 * * * \\
(0.28)\end{array}$ & $\begin{array}{c}0.10 \\
(0.09)\end{array}$ & $\begin{array}{l}0.19 * \\
(0.11)\end{array}$ \\
\hline Change in net household income (1000 USD) & - & $\begin{array}{l}0.02 * \\
(0.01)\end{array}$ & $\begin{array}{c}0.005 * * \\
(0.00)\end{array}$ \\
\hline Farm size (ha) & - & - & - \\
\hline Share of total land certified & - & - & - \\
\hline Share of cultivated area under F\&V & - & - & - \\
\hline Share F\&V area with sprinkler/drip irrigation & $\begin{array}{c}1.09 * * * \\
(0.39)\end{array}$ & - & - \\
\hline Q-GAP certified (0/1) & $\begin{array}{c}0.67 * * \\
(0.28)\end{array}$ & - & - \\
\hline Constant & $\begin{array}{c}-3.11 * * * \\
(0.85) \\
\end{array}$ & $\begin{array}{c}-3.71 * * * \\
(1.23) \\
\end{array}$ & - \\
\hline Correlation rho & & $-0.05(0.46)$ & \\
\hline Log pseudo-likelihood & & -149.6753 & \\
\hline Wald chi2 & & 38.8 & \\
\hline Prob > chi2 & & 0.00 & \\
\hline
\end{tabular}

Notes: Statistical significance at the $1 \%(* * *), 5 \%(* *)$ and $10 \%(*)$ levels. Coefficient estimates are shown with cluster robust standard errors in parentheses.

a The reference group is farmers that did not receive support to manage the QMS.

Source: Own data 


\section{Appendix V: Descriptive statistics}

Table A11: Descriptive statistics - continued compliance with GlobalGAP

\begin{tabular}{|c|c|c|c|c|}
\hline & \multicolumn{2}{|c|}{$\begin{array}{l}2010 \\
\text { GlobalGAP certified (N=72) }\end{array}$} & \multicolumn{2}{|c|}{$\begin{array}{l}2009 \\
\text { Full sample }(\mathrm{N}=214) \\
\end{array}$} \\
\hline & $\begin{array}{c}\text { Continued } \\
\text { adopters } \\
(\mathbf{N}=18) \\
\end{array}$ & $\begin{array}{l}\text { Disadopters } \\
\quad(\mathrm{N}=54)\end{array}$ & $\begin{array}{l}\text { Certified } \\
(\mathrm{N}=72)\end{array}$ & $\begin{array}{l}\text { Non-certified } \\
\qquad(\mathrm{N}=142)\end{array}$ \\
\hline Exporter support in \% (0/1) & $77.78 * * *$ & 16.67 & $31.94 * * *$ & 13.38 \\
\hline Donor support in \% (0/1) & $\mathrm{n} / \mathrm{a}$ & $\mathrm{n} / \mathrm{a}$ & $55.56^{* * *}$ & 8.45 \\
\hline Number extension topics & $\begin{array}{c}4.17 \\
(3.33)\end{array}$ & $\begin{array}{l}5.20 \\
(2.84)\end{array}$ & $\begin{array}{c}5.49 * * * \\
(3.13)\end{array}$ & $\begin{array}{l}1.26 \\
(2.30)\end{array}$ \\
\hline $\begin{array}{l}\text { College graduate in the household } \\
(0 / 1) \text { in } \%\end{array}$ & 61.11 & 40.74 & 43.06 & 32.39 \\
\hline $\begin{array}{l}\text { Change in net household income } \\
\text { (1000 USD) }\end{array}$ & $\begin{array}{c}12,079 \\
(32,986)\end{array}$ & $\begin{array}{c}3794 \\
(13,792)\end{array}$ & $\mathrm{n} / \mathrm{a}$ & $\mathrm{n} / \mathrm{a}$ \\
\hline Age of the household head & $\begin{array}{c}51.83 \\
(15.46)\end{array}$ & $\begin{array}{l}49.89 \\
(8.44)\end{array}$ & $\begin{array}{l}45.75^{* * *} \\
(7.91)\end{array}$ & $\begin{array}{c}51.80 \\
(11.57)\end{array}$ \\
\hline Number of household members & $\begin{array}{c}4.83 \\
(3.17)\end{array}$ & $\begin{array}{c}4.00 \\
(1.66)\end{array}$ & $\begin{array}{c}4.13 \\
(1.39)\end{array}$ & $\begin{array}{c}4.08 \\
(1.50)\end{array}$ \\
\hline Farm size (ha) & $\begin{array}{c}4.21 \\
(3.99)\end{array}$ & $\begin{array}{l}3.18 \\
(3.06)\end{array}$ & $\begin{array}{c}2.49 \\
(2.44)\end{array}$ & $\begin{array}{l}3.87 \\
(7.10)\end{array}$ \\
\hline Share of total land that is certified & $\begin{array}{c}0.43 \\
(0.36)\end{array}$ & $\begin{array}{c}0.44 \\
(0.32)\end{array}$ & $\mathrm{n} / \mathrm{a}$ & $\mathrm{n} / \mathrm{a}$ \\
\hline Share of cultivated area under F\&V & $\mathrm{n} / \mathrm{a}$ & $\mathrm{n} / \mathrm{a}$ & $\begin{array}{c}0.65 \\
(0.35)\end{array}$ & $\begin{array}{c}0.85 \\
(0.26)\end{array}$ \\
\hline $\begin{array}{l}\text { Share of cultivated area with F\&V that is } \\
\text { irrigated (sprinklers, drip irrigation) }\end{array}$ & $\mathrm{n} / \mathrm{a}$ & $\mathrm{n} / \mathrm{a}$ & $\begin{array}{c}0.91 * * * \\
(0.27)\end{array}$ & $\begin{array}{c}0.65 \\
(0.46)\end{array}$ \\
\hline Q-GAP certified in \% (0/1) & $\mathrm{n} / \mathrm{a}$ & $\mathrm{n} / \mathrm{a}$ & $91.67 * * *$ & 38.03 \\
\hline
\end{tabular}

Notes: Statistical significance at the $1 \%\left(^{* * *}\right), 5 \%(* *)$ and $10 \%(*)$ levels. Standard deviations are shown in parentheses.

Source: Own data 


\section{Appendix VI: Questionnaire}

\section{Questionnaire about standard adoption and impacts of standards in Thailand ${ }^{71}$}

\section{A. Introduction}

\begin{tabular}{|l|l|}
\hline Date of the survey & \\
\hline Name of the enumerator & \\
\hline Household code (put this number on top of every page) & \\
\hline
\end{tabular}

A1. Of which group is this household a member?

\begin{tabular}{|l|c|c|c|}
\hline & $\begin{array}{c}\text { GTZ project } \\
\text { participant }\end{array}$ & $\begin{array}{c}\text { Control group for } \\
\text { GTZ project }\end{array}$ & $\begin{array}{c}\text { External control group } \\
\text { for GTZ project }\end{array}$ \\
\hline C.O. Suansrakaew & $\square$ & $\square$ & $\square$ \\
\hline Safety Farm & $\square$ & $\square$ & $\square$ \\
\hline Shine Forth Co. Ltd. & $\square$ & $\square$ & $\square$ \\
\hline $\begin{array}{l}\text { Chatchawan Import Export and } \\
\text { Packaging Ltd. }\end{array}$ & $\square$ & $\square$ & $\square$ \\
\hline Chatchawan Orchid Co. Ltd. & $\square$ & $\square$ & $\square$ \\
\hline Siam Export Mart Co. Ltd. & $\square$ & $\square$ & $\square$ \\
\hline Cantaloupe Grower Group Pachee & $\square$ & $\square$ & $\square$ \\
\hline PDI Trading & $\square$ & $\square$ & $\square$ \\
\hline $\begin{array}{l}\text { Fruit Producer Chumporn Group of } \\
\text { Export Quality }\end{array}$ & $\square$ & $\square$ & $\square$ \\
\hline Phol Intergrower Co. Ltd. & $\square$ & $\square$ & $\square$ \\
\hline KC Eastern Fruit Group & $\square$ & $\square$ & $\square$ \\
\hline
\end{tabular}

A2. Please give your name, address and telephone number

\begin{tabular}{|l|l|}
\hline Respondents name & \\
\hline Street & \\
\hline Village & \\
\hline District & \\
\hline Province & \\
\hline Telephone number & \\
\hline
\end{tabular}

\footnotetext{
${ }^{71}$ The questionnaire presented here is the questionnaire that was used during the second survey round in 2011. The questionnaire used during the baseline survey in 2010 is structured similarly and can be provided on request.
} 
B. Information on the household

B1. Please give some information about the household members, starting with the head of the household. (Note: Members of a household are all people who usually eat from the same pot and sleep under the same roof. Include also members who were absent for less than two month during the last 12 months).

\begin{tabular}{|c|c|c|c|c|c|c|c|c|c|c|c|c|c|c|c|c|c|c|}
\hline \multirow[t]{3}{*}{ ID } & \multirow{3}{*}{$\begin{array}{c}\text { Relation } \\
\text { with } \\
\text { household } \\
\text { head } \\
\text { Code } 1\end{array}$} & \multirow[t]{3}{*}{ Age } & \multirow{3}{*}{$\begin{array}{c}\text { Gender } \\
0= \\
\text { male } \\
1= \\
\text { female }\end{array}$} & \multirow[t]{3}{*}{$\begin{array}{l}\text { Years of } \\
\text { schooling }\end{array}$} & \multirow{3}{*}{$\begin{array}{c}\text { Highest } \\
\text { educational } \\
\text { level } \\
\text { achieved } \\
\text { Code } 2\end{array}$} & \multirow{3}{*}{$\begin{array}{c}\text { Does this } \\
\text { household } \\
\text { member } \\
\text { still go to } \\
\text { school? } \\
0 \text { No } \\
1 \text { Yes }\end{array}$} & \multirow{3}{*}{$\begin{array}{c}\text { How much } \\
\text { does this } \\
\text { person } \\
\text { work on } \\
\text { your farm? } \\
\text { Code } 3\end{array}$} & \multicolumn{3}{|c|}{$\begin{array}{l}\text { If the person works on the } \\
\text { farm, how many }\end{array}$} & \multirow{3}{*}{$\begin{array}{c}\text { Does the } \\
\text { person } \\
\text { work off- } \\
\text { farm? } \\
0=\text { No } \\
1=\text { Yes }\end{array}$} & \multicolumn{7}{|c|}{ Only of this person is works off-farm work } \\
\hline & & & & & & & & \multirow[t]{2}{*}{$\begin{array}{l}\text { months/ } \\
\text { year? }\end{array}$} & \multirow[t]{2}{*}{$\begin{array}{c}\text { days/ } \\
\text { week? }\end{array}$} & \multirow[t]{2}{*}{$\begin{array}{l}\text { hours/ } \\
\text { day? }\end{array}$} & & \multirow{2}{*}{$\begin{array}{c}\text { Specify } \\
\text { type of } \\
\text { job } \\
\text { Code } 4\end{array}$} & \multirow{2}{*}{$\begin{array}{c}\text { Years } \\
\text { engaged } \\
\text { in the } \\
\text { activity }\end{array}$} & \multicolumn{2}{|c|}{$\begin{array}{l}\text { How often does } \\
\text { the person work } \\
\text { off-farm? }\end{array}$} & \multicolumn{3}{|c|}{$\begin{array}{l}\text { What is the average } \\
\text { income? }\end{array}$} \\
\hline & & & & & & & & & & & & & & $\begin{array}{l}\text { days/ } \\
\text { week }\end{array}$ & $\begin{array}{l}\text { days/ } \\
\text { month }\end{array}$ & $\begin{array}{l}\text { per } \\
\text { day }\end{array}$ & $\begin{array}{c}\text { per } \\
\text { month }\end{array}$ & $\begin{array}{l}\text { per } \\
\text { year }\end{array}$ \\
\hline 1 & & & & & & & & & & & & & & & & & & \\
\hline 2 & & & & & & & & & & & & & & & & & & \\
\hline 3 & & & & & & & & & & & & & & & & & & \\
\hline 4 & & & & & & & & & & & & & & & & & & \\
\hline 5 & & & & & & & & & & & & & & & & & & \\
\hline 6 & & & & & & & & & & & & & & & & & & \\
\hline 7 & & & & & & & & & & & & & & & & & & \\
\hline 8 & & & & & & & & & & & & & & & & & & \\
\hline 9 & & & & & & & & & & & & & & & & & & \\
\hline 10 & & & & & & & & & & & & & & & & & & \\
\hline 11 & & & & & & & & & & & & & & & & & & \\
\hline
\end{tabular}

B2. Member ID of the interviewee:

B3. Member ID of the person that is mainly responsible for agricultural decisions within the household:

\begin{tabular}{|c|c|c|c|}
\hline Code 1: & Code 2: & Code 3: & Code 4: \\
\hline 1 Household head & $\begin{array}{ll}0 & \text { No formal education }\end{array}$ & $0 \quad$ Does not work in agriculture & 1 Collector/middleman \\
\hline 2 Spouse household head & 1 Primary school grade 4 & 1 Full time & Self-employed in agriculture \\
\hline Son or daughter & 2 Primary school grade 6 & 2 Half time & Self-employed in non-farm enterprise \\
\hline Father or mother & Lower secondary school & 3 Only at harvest time & $4 \quad$ Government employee \\
\hline Grandchild & Upper secondary school & Weekends and holidays only & Casual worker non-agriculture \\
\hline Grandparents & 5 Certificate in Vocational Education & $5 \quad$ Helping sometimes & Day laborer in agriculture \\
\hline Son- and daughter-in-law & $6 \quad$ Technical Diploma & $6 \quad$ Other, please specify & 7 Salaried worker in agriculture \\
\hline Sister or brother & $7 \quad$ Bachelor degree & & 8 Salaried worker in non-agriculture \\
\hline Sister or brother in-law & $8 \quad$ Master degree & & $9 \quad$ Domestic worker \\
\hline Other relative & Doctoral degree & & 10 Other (specify) \\
\hline Other non-relative & Other & & \\
\hline
\end{tabular}




\section{Information on the farm, agricultural production and marketing}

C1. In which year did this farm business start?

C2. What is the size of your farm in rai?

C3. How far is the farm from the following?

\begin{tabular}{|c|c|c|}
\hline From & $\mathrm{km}$ & $\begin{array}{c}\text { How do you usually go there? } \\
1=\text { by foot } / 2=\text { by bicycle } / 3=\text { by motorbike/ } 4=\text { by car } / 5=\text { by public } \\
\text { transport }\end{array}$ \\
\hline 1 Nearest town & & \\
\hline 2 Next paved road & & \\
\hline 3 Homestead & & \\
\hline
\end{tabular}

C4. Do you deliver produce to a collection centre?

0 No

1 Yes

C4.1. If yes, what products and how far is the collection centre from your farm?

\begin{tabular}{|c|c|c|}
\hline $\begin{array}{c}\text { Products } \\
\text { (product codes) }\end{array}$ & $\mathrm{km}$ & $\begin{array}{c}\text { How do you usually go there? } \\
1=\text { by foot/ } 2=\text { by bicycle/ } 3=\text { by motorbike/ } 4=\text { by car } / 5=\text { by public } \\
\text { transport }\end{array}$ \\
\hline & & \\
\hline & & \\
\hline & & \\
\hline & & \\
\hline
\end{tabular}

C5. Please draw a map of all plots you owned and rented in time period March 2010 to the end of February 2011. Please draw in the area of each plot, the product which is produced and the numbers of the plots. If you rotate crops, always indicate during which months which product is grown on the plot. Also draw in the area where livestock is kept. 
C6. Please fill in the table all the plots the household owned and rented from March 2010 to the end of February 2011.

\begin{tabular}{|c|c|c|c|c|c|c|c|c|c|c|c|c|}
\hline \multirow[t]{2}{*}{$\begin{array}{l}\text { Plot } \\
\text { no. }\end{array}$} & \multirow{2}{*}{$\begin{array}{c}\text { Area of } \\
\text { the plot } \\
\text { (rai) }\end{array}$} & \multirow{2}{*}{$\begin{array}{l}\text { Type of } \\
\text { soil } \\
\text { Code } 1\end{array}$} & \multirow{2}{*}{$\begin{array}{l}\text { In which } \\
\text { year did } \\
\text { you } \\
\text { acquire/ } \\
\text { start } \\
\text { renting the } \\
\text { plot? }\end{array}$} & \multirow{2}{*}{$\begin{array}{l}\text { Which is } \\
\text { the } \\
\text { ownership } \\
\text { status of } \\
\text { this plot? } \\
\text { Code } 2\end{array}$} & \multicolumn{3}{|c|}{ If plot is owned, } & \multicolumn{3}{|c|}{ If the plot is rented } & \multicolumn{2}{|c|}{$\begin{array}{c}\text { If there is a sharecropping } \\
\text { agreement }\end{array}$} \\
\hline & & & & & $\begin{array}{c}\text { which } \\
\text { household } \\
\text { member } \\
\text { owns the } \\
\text { plot? } \\
\text { (Member } \\
\text { I.D. code) }\end{array}$ & $\begin{array}{c}\text { Is there a } \\
\text { land title for } \\
\text { this plot? } \\
0=\text { No } \\
1=\text { Yes }\end{array}$ & $\begin{array}{l}\text { If there is a } \\
\text { land title, } \\
\text { specify type } \\
\text { of land title } \\
\text { Code } 3\end{array}$ & $\begin{array}{l}\text { Who owns } \\
\text { the plot? } \\
\text { Code } 4\end{array}$ & $\begin{array}{l}\text { Rent cash in } \\
\text { Baht } \\
\text { (always } \\
\text { indicate per } \\
\text { rai/total } \\
\text { area) }\end{array}$ & Rent in kind & $\begin{array}{c}\text { Who owns } \\
\text { the plot? } \\
\text { Code } 4\end{array}$ & $\begin{array}{c}\text { Please } \\
\text { describe the } \\
\text { share- } \\
\text { cropping } \\
\text { agreement }\end{array}$ \\
\hline 1 & & & & & & & & & & & & \\
\hline 2 & & & & & & & & & & & & \\
\hline 3 & & & & & & & & & & & & \\
\hline 4 & & & & & & & & & & & & \\
\hline 5 & & & & & & & & & & & & \\
\hline 6 & & & & & & & & & & & & \\
\hline 7 & & & & & & & & & & & & \\
\hline 8 & & & & & & & & & & & & \\
\hline 9 & & & & & & & & & & & & \\
\hline 10 & & & & & & & & & & & & \\
\hline 11 & & & & & & & & & & & & \\
\hline
\end{tabular}

\begin{tabular}{|c|c|c|c|}
\hline $\begin{array}{l}\text { Code 1: Read } \\
\text { choices out loud }\end{array}$ & Code 2: Read choices out loud & Code 3: Read choices out loud & Code 4: Read choices out loud \\
\hline $\begin{array}{ll}1 & \text { Fertile soils } \\
2 & \text { Medium-fertile } \\
& \text { soils } \\
3 & \text { Less-fertile } \\
& \text { soils }\end{array}$ & $\begin{array}{ll}1 & \text { Owned } \\
2 & \text { Rented } \\
3 & \text { Sharecropping } \\
4 & \text { Owned by a relative and given to the household for cultivation } \\
5 & \text { Owned by a friend and given to the household for cultivation } \\
6 & \text { Owned by the government and given to the household for } \\
& \text { cultivation } \\
7 & \text { Other, please specify }\end{array}$ & $\begin{array}{ll}1 & \text { Chanot Thi Din - No So Si } \\
\text { Cho } \\
2 \\
2 \text { Sor Por Kor (S. P. K.) / So Po } \\
\text { Go (S. P. G.) } \\
3 \text { Po Bo Tor } 5 \\
4 & \text { No Pa Go } \\
5 & \text { Other, please specify }\end{array}$ & $\begin{array}{ll}1 & \text { First-degree relative } \\
2 & \text { Other relative } \\
3 & \text { Neighbor (but not relative) } \\
4 & \text { Friend (but not relative) } \\
5 & \text { Other person }\end{array}$ \\
\hline
\end{tabular}


C7. Please tell me about your irrigation system and your water use in the time period March 2010 to the end of February 2011.

Use the same numbers for the plots as in table C6.

\begin{tabular}{|c|c|c|c|c|c|c|c|c|c|c|c|c|}
\hline \multirow[t]{3}{*}{ Plot no. } & \multirow{3}{*}{$\begin{array}{l}\text { Type of } \\
\text { irrigation } \\
\text { system } \\
\text { Code } 1 \\
\text { (specify if } \\
\text { manual } \\
\text { irrigation) }\end{array}$} & \multirow{3}{*}{$\begin{array}{l}\text { Irrigated } \\
\text { crop } \\
\text { Product } \\
\text { codes }\end{array}$} & \multirow{3}{*}{$\begin{array}{c}\text { Size of } \\
\text { irrigated } \\
\text { area }\end{array}$} & \multirow{3}{*}{$\begin{array}{c}\text { Source of } \\
\text { irrigation } \\
\text { water } \\
\text { Code } 2\end{array}$} & \multirow{3}{*}{$\begin{array}{l}\text { Month during which } \\
\text { the crop is irrigated }\end{array}$} & \multicolumn{6}{|c|}{ How often do you irrigate this plot (not for flooding)? } & \multirow{3}{*}{$\begin{array}{c}\text { At which time of } \\
\text { the day do you } \\
\text { irrigate? }\end{array}$} \\
\hline & & & & & & \multicolumn{2}{|c|}{$\begin{array}{c}\text { Hot season } \\
\text { (March-May) }\end{array}$} & \multicolumn{2}{|c|}{$\begin{array}{l}\text { Raining season } \\
\text { (June-October) }\end{array}$} & \multicolumn{2}{|c|}{$\begin{array}{c}\text { Cold season } \\
\text { (November- } \\
\text { February) }\end{array}$} & \\
\hline & & & & & & $\begin{array}{l}\text { days/ } \\
\text { week }\end{array}$ & $\begin{array}{c}\text { minutes/ } \\
\text { day }\end{array}$ & $\begin{array}{l}\text { days/ } \\
\text { week }\end{array}$ & $\begin{array}{c}\text { minutes/ } \\
\text { day }\end{array}$ & $\begin{array}{l}\text { days/ } \\
\text { week }\end{array}$ & $\begin{array}{c}\text { minutes/ } \\
\text { day }\end{array}$ & \\
\hline \multicolumn{13}{|l|}{1} \\
\hline \multirow{2}{*}{\multicolumn{13}{|c|}{2}} \\
\hline & & & & & & & & & & & & \\
\hline \multicolumn{13}{|l|}{3} \\
\hline & & & & & & & & & & & & \\
\hline \multicolumn{13}{|l|}{4} \\
\hline \multirow{2}{*}{\multicolumn{13}{|c|}{5}} \\
\hline & & & & & & & & & & & & \\
\hline \multirow{2}{*}{\multicolumn{13}{|c|}{6}} \\
\hline & & & & & & & & & & & & \\
\hline \multicolumn{13}{|l|}{7} \\
\hline & & & & & & & & & & & & \\
\hline \multicolumn{13}{|l|}{8} \\
\hline & & & & & & & & & & & & \\
\hline
\end{tabular}

Code 1: Let the farmer answer and select the code. If necessary read choices out loud
$0 \quad$ No, I don't irrigate this plot
4 Drip irrigation
1 Manual irrigation, please speci
5 Sprinkler irrigation
2 Flooding
6 Other (specify)

3 Furrow irrigation

\section{Code 2: Let the farmer answer and select the code. If necessary read choices out loud}

1 Underground or well water (include shallow wells and deep wells)

2 ON-FARM lakes, rivers, creeks or streams, ponds or dugouts i.e. direct access (surface water)

3 Water from a rain collection system (e.g., cistern or rain barrel)

4 OFF-FARM water transported TO THE FARM e.g., via pipeline, canal system or vehicle

5 Other (specify) 
C8. Harvesting calendar

\begin{tabular}{|c|c|c|c|c|c|c|c|c|c|c|c|c|c|}
\hline $\begin{array}{c}\text { Plot } \\
\text { number }\end{array}$ & $\begin{array}{c}\text { Product } \\
\text { (product } \\
\text { codes) }\end{array}$ & $\begin{array}{c}3 \\
\text { March }\end{array}$ & $\begin{array}{c}4 \\
\text { April }\end{array}$ & $\begin{array}{c}5 \\
\text { May }\end{array}$ & $\begin{array}{c}6 \\
\text { June }\end{array}$ & $\begin{array}{c}7 \\
\text { July }\end{array}$ & $\begin{array}{c}8 \\
\text { August }\end{array}$ & $\begin{array}{c}9 \\
\text { September }\end{array}$ & $\begin{array}{c}10 \\
\text { October }\end{array}$ & $\begin{array}{c}11 \\
\text { November }\end{array}$ & $\begin{array}{c}12 \\
\text { December }\end{array}$ & $\begin{array}{c}1 \\
\text { January }\end{array}$ & $\begin{array}{c}2 \\
\text { February }\end{array}$ \\
\hline & & & & & & & & & & & & & \\
\hline & & & & & & & & & & & & & \\
\hline & & & & & & & & & & & & & \\
\hline & & & & & & & & & & & & & \\
\hline & & & & & & & & & & & & & \\
\hline & & & & & & & & & & & & & \\
\hline & & & & & & & & & & & & & \\
\hline & & & & & & & & & & & & & \\
\hline & & & & & & & & & & & & & \\
\hline & & & & & & & & & & & & & \\
\hline & & & & & & & & & & & & & \\
\hline & & & & & & & & & & & & & \\
\hline & & & & & & & & & & & & & \\
\hline & & & & & & & & & & & & & \\
\hline & & & & & & & & & & & & & \\
\hline & & & & & & & & & & & & & \\
\hline & & & & & & & & & & & & & \\
\hline & & & & & & & & & & & & & \\
\hline & & & & & & & & & & & & & \\
\hline & & & & & & & & & & & & & \\
\hline & & & & & & & & & & & & & \\
\hline & & & & & & & & & & & & & \\
\hline & & & & & & & & & & & & & \\
\hline & & & & & & & & & & & & & \\
\hline
\end{tabular}


C9. Please give information on agricultural production on your farm in the time period March 2010 to the end of February 2011. (Note: First list only one plot, then list the main product produced on this plot and fill out the other columns. If there has been more than one harvest on this plot in the last 12 months, please use one line per harvest. If there is more than one product produced on this plot, continue with filling out the questionnaire for the other product. Then continue with the next plot.)

\begin{tabular}{|c|c|c|c|c|c|c|c|c|c|c|c|c|c|}
\hline $\begin{array}{c}\text { Code } \\
\text { of } \\
\text { plot from } \\
\text { Table C6. }\end{array}$ & \begin{tabular}{|} 
Product(s) \\
Product \\
codes
\end{tabular} & $\begin{array}{l}\text { Years of } \\
\text { experience in } \\
\text { growing the } \\
\text { product? }\end{array}$ & $\begin{array}{c}\text { Production? } \\
0 \mathrm{No} / \\
1 \mathrm{Yes}\end{array}$ & Variety & $\begin{array}{c}\text { Size of the } \\
\text { area where you } \\
\text { cultivate the } \\
\text { product }\end{array}$ & $\begin{array}{c}\text { Number of } \\
\text { plants }\end{array}$ & $\begin{array}{l}\text { Age of } \\
\text { plant/ } \\
\text { tree }\end{array}$ & $\begin{array}{c}\text { If } \\
\text { intercropped, } \\
\% \text { of areas } \\
\text { for different } \\
\text { products }\end{array}$ & $\begin{array}{c}\text { No. } \\
\text { of } \\
\text { harvests }\end{array}$ & $\begin{array}{l}\text { Harvesting } \\
\text { period } \\
\text { (e.g. } \\
\text { August to } \\
\text { September) }\end{array}$ & $\begin{array}{c}\text { No. of } \\
\text { harvesting } \\
\text { days }\end{array}$ & Yield & $\begin{array}{l}\text { Total yield/ } \\
\text { year }\end{array}$ \\
\hline & & & & & & & & & & & & & \\
\hline & & & & & & & & & & & & & \\
\hline & & & & & & & & & & & & & \\
\hline & & & & & & & & & & & & & \\
\hline & & & & & & & & & & & & & \\
\hline & & & & & & & & & & & & & \\
\hline & & & & & & & & & & & & & \\
\hline & & & & & & & & & & & & & \\
\hline & & & & & & & & & & & & & \\
\hline & & & & & & & & & & & & & \\
\hline & & & & & & & & & & & & & \\
\hline & & & & & & & & & & & & & \\
\hline & & & & & & & & & & & & & \\
\hline & & & & & & & & & & & & & \\
\hline & & & & & & & & & & & & & \\
\hline & & & & & & & & & & & & & \\
\hline & & & & & & & & & & & & & \\
\hline & & & & & & & & & & & & & \\
\hline & & & & & & & & & & & & & \\
\hline & & & & & & & & & & & & & \\
\hline & & & & & & & & & & & & & \\
\hline
\end{tabular}


C10. Please tell me about the marketing of your products in the last 12 months (March 2010 to the end of February 2011). Always specify the name of the buyer if it is asked for!

\begin{tabular}{|c|c|c|c|c|c|c|c|c|c|c|c|c|}
\hline \multirow{2}{*}{$\begin{array}{l}\text { Enter } \\
\text { products } \\
\text { from } \\
\text { table C9 }\end{array}$} & \multirow[t]{2}{*}{$\begin{array}{c}\text { No. of } \\
\text { harvests }\end{array}$} & \multicolumn{2}{|c|}{$\begin{array}{c}\text { How much of the } \\
\text { harvest were you } \\
\text { able to sell? }\end{array}$} & \multirow[t]{2}{*}{$\begin{array}{l}\text { Buyers } \\
\text { Code } 1\end{array}$} & \multicolumn{2}{|c|}{$\begin{array}{c}\text { Of the harvest sold: } \\
\text { Quantity sold/ } \\
\text { harvest/buyer }\end{array}$} & \multirow[t]{2}{*}{$\begin{array}{l}\text { What are the grades } \\
\text { used by the buyer? }\end{array}$} & \multicolumn{2}{|c|}{$\begin{array}{c}\text { Quantity } \\
\text { sold/buyer/ } \\
\text { grade }\end{array}$} & \multirow{2}{*}{$\begin{array}{l}\text { Price received by } \\
\text { buyer/grade/ } \\
\text { kg in THB }\end{array}$} & \multirow{2}{*}{$\begin{array}{c}\text { Value } \\
\text { received/ } \\
\text { buyer/ grade } \\
\text { in THB }\end{array}$} & \multirow{2}{*}{$\begin{array}{l}\text { Total value } \\
\text { received per } \\
\text { buyer/produc } \\
\text { in THB }\end{array}$} \\
\hline & & in $\%$ & in $\mathrm{kg}$ & & in $\%$ & in $\mathrm{kg}$ & & in $\%$ & in $\mathrm{kg}$ & & & \\
\hline & & & & & & & & & & & & \\
\hline & & & & & & & & & & & & \\
\hline & & & & & & & & & & & & \\
\hline & & & & & & & & & & & & \\
\hline & & & & & & & & & & & & \\
\hline & & & & & & & & & & & & \\
\hline & & & & & & & & & & & & \\
\hline & & & & & & & & & & & & \\
\hline & & & & & & & & & & & & \\
\hline & & & & & & & & & & & & \\
\hline & & & & & & & & & & & & \\
\hline & & & & & & & & & & & & \\
\hline & & & & & & & & & & & & \\
\hline & & & & & & & & & & & & \\
\hline
\end{tabular}

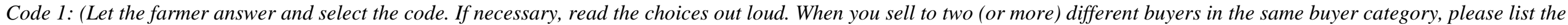
category twice (or more)

1 Middlemen/collector in the village

2 Farmer group/co-op, please specify

3 Wholesale market, please specify

4 Supplier of a supermarket/retailer, please specify supermarket/retailer

\section{Supermarket/retailer, please specify}

6 Middleman/broker supplying an exporter enterprise,

please specify exporter

7 I sell it directly to an exporter enterprise, please specify

8 I sell it to a processor, please specify

\section{Rice mil}

10Farmer sells by him/herself

11Other, please specify 
C12. For how many years have you grown for export? Differentiate according to the products that are exported (product codes).

\begin{tabular}{|l|l|l|l|l|l|l|l|l|l|l|l|l|l|l|}
\hline Product & Years & Product & Years & Product & Years & Product & Years & Product & Years & Product & Years & Product & Years & Product \\
\hline & & & & & & & & & & & & & & \\
\hline
\end{tabular}

C13. Please give information about your buyers and the agreements with your buyers. For codes see extra sheet agreements with buyer codes. Always specify the choice if indicated by the codes!

\begin{tabular}{|c|c|c|c|c|c|c|c|c|c|c|c|c|}
\hline $\begin{array}{c}\text { Buyer } \\
\text { ID }\end{array}$ & $\begin{array}{l}\text { Please list all the } \\
\text { buyers you sold to } \\
\text { in the time period } \\
\text { March } 2010 \text { the end } \\
\text { of February } 2011 . \\
\text { List the buyers from } \\
\text { C10. }\end{array}$ & $\begin{array}{c}\text { Product } \\
\text { (product } \\
\text { codes) }\end{array}$ & $\begin{array}{l}\text { When did } \\
\text { you first } \\
\text { deliver to } \\
\text { this buyer } \\
\text { (year)? }\end{array}$ & $\begin{array}{l}\text { What kind of } \\
\text { agreement do } \\
\text { you have } \\
\text { with the } \\
\text { buyer? } \\
\text { Code } 1\end{array}$ & $\begin{array}{l}\text { If agreement } \\
\text { exists: Which time } \\
\text { period does the } \\
\text { arrangement } \\
\text { between you and } \\
\text { the buyer cover? } \\
\text { Code } 2\end{array}$ & $\begin{array}{l}\text { Can you } \\
\text { negotiate } \\
\text { the price } \\
\text { with the } \\
\text { buyer? } \\
0=\text { No / } \\
1=\text { Yes }\end{array}$ & $\begin{array}{l}\text { How } \\
\text { did the } \\
\text { buyer } \\
\text { pay } \\
\text { you? } \\
\text { Code } 3\end{array}$ & $\begin{array}{l}\text { Does the } \\
\text { buyer } \\
\text { provide } \\
\text { credits? } \\
0=\text { No } \\
1=\text { Yes }\end{array}$ & $\begin{array}{l}\text { Did the } \\
\text { buyer } \\
\text { provide } \\
\text { any } \\
\text { inputs? } \\
\text { Code } 4\end{array}$ & $\begin{array}{l}\text { If yes: } \\
\text { How did } \\
\text { you pay } \\
\text { the } \\
\text { inputs? } \\
\text { Code } 5\end{array}$ & $\begin{array}{l}\text { How } \\
\text { was the } \\
\text { product } \\
\text { delivered } \\
\text { to the } \\
\text { buyer? } \\
\text { Code } 6\end{array}$ & $\begin{array}{l}\text { Does the } \\
\text { buyer visit } \\
\text { you in the } \\
\text { field to give } \\
\text { advice and } \\
\text { services? } \\
0 \text { No / } 1 \text { Yes }\end{array}$ \\
\hline 1 & & & & & & & & & & & & \\
\hline 2 & & & & & & & & & & & & \\
\hline 3 & & & & & & & & & & & & \\
\hline 4 & & & & & & & & & & & & \\
\hline 5 & & & & & & & & & & & & \\
\hline 6 & & & & & & & & & & & & \\
\hline
\end{tabular}

C14. If you have a written or oral agreement with a buyer, what are the requirements of the buyer for delivered produce?
\begin{tabular}{|l|l|l|l|l|l|}
\hline & $\begin{array}{l}\text { Buyer ID: } \begin{array}{l}\text { Product } \\
\text { code(s): }\end{array} \\
\text { Product } \\
\text { code(s): }\end{array}$ & $\begin{array}{l}\text { Buyer ID: } \\
\text { Product } \\
\text { code(s): }\end{array}$ & $\begin{array}{l}\text { Buyer ID: } \\
\text { Product } \\
\text { code(s): }\end{array}$ & $\begin{array}{l}\text { Buyer ID: } \\
\text { Product } \\
\text { code(s): }\end{array}$ & $\begin{array}{l}\text { Buyer ID: } \\
\text { Product } \\
\text { code(s): }\end{array}$ \\
\hline $1 \quad$ I must deliver the whole harvest of in-grade produce to the buyer & $\square$ & $\square$ & $\square$ & $\square$ & $\square$ \\
\hline $2 \quad$ Use of only those crop protection products which are approved by the buyer & $\square$ & $\square$ & $\square$ & $\square$ & $\square$ \\
\hline $3 \quad$ I must keep detailed records about the use of crop protection products and fertilizer & $\square$ & $\square$ & $\square$ & $\square$ \\
\hline $4 \quad$ I needed to have a Q-GAP certificate & $\square$ & $\square$ & $\square$ & $\square$ \\
\hline $5 \quad$ I needed to be certified against a standard (other than Q-GAP), please specify & $\square$ & $\square$ & $\square$ & $\square$ & $\square$ \\
\hline $6 \quad$ Other, please specify & $\square$ & $\square$ & $\square$ & $\square$ \\
\hline
\end{tabular}


C15. If you have a written or oral agreement with a buyer, which of the following have you agreed upon before the exchange took place?

\begin{tabular}{|c|c|c|c|c|c|}
\hline & $\begin{array}{l}\text { Buyer ID: } \\
\text { Product } \\
\text { code(s): }\end{array}$ & $\begin{array}{l}\text { Buyer ID: } \\
\text { Product } \\
\text { code(s): }\end{array}$ & $\begin{array}{l}\text { Buyer ID: } \\
\text { Product } \\
\text { code(s): }\end{array}$ & $\begin{array}{l}\text { Buyer ID: } \\
\text { Product } \\
\text { code(s): }\end{array}$ & $\begin{array}{l}\text { Buyer ID: } \\
\text { Product } \\
\text { code(s): }\end{array}$ \\
\hline 1 Grading of product & $\square$ & $\square$ & $\square$ & $\square$ & $\square$ \\
\hline 2 Prices & $\square$ & $\square$ & $\square$ & $\square$ & $\square$ \\
\hline 3 Timing of delivery of the product & $\square$ & $\square$ & $\square$ & $\square$ & $\square$ \\
\hline 4 Amount of product to be delivered & $\square$ & $\square$ & $\square$ & $\square$ & $\square$ \\
\hline 5 Other, please specify & $\square$ & $\square$ & $\square$ & $\square$ & $\square$ \\
\hline
\end{tabular}

C16. Do farm advisors/agronomists of the buyer visit you in the field and which services are provided? Please use one line per service provider and per service.

\begin{tabular}{|l|l|l|}
\hline $\begin{array}{l}\text { Who visits you in the fields? Ask for the buyers in Table } \\
\text { C13. and for exporters/companies who send farm } \\
\text { advisors or provide services (no input dealers!) }\end{array}$ & $\begin{array}{c}\text { How often are } \\
\text { you visited in the } \\
\text { fields? } \\
\text { Code 1 }\end{array}$ & $\begin{array}{c}\text { What type of advise/service is given? } \\
\text { Code 2 }\end{array}$ \\
\hline Buyer ID: & & \\
\hline Buyer ID: & & \\
\hline Buyer ID: & & \\
\hline Name of exporter/company: & & \\
\hline
\end{tabular}

\begin{tabular}{|c|c|}
\hline \multicolumn{2}{|c|}{ Code 1 (Let the farmer answer and select the code) } \\
\hline 1 More than once a week & Every three months \\
\hline 2 Once a week & 7 Two to three times a year \\
\hline 3 Every two to three weeks & 8 Once a year \\
\hline 4 Once a month & 9 Less than once a year \\
\hline 5 Every two months & 10 Other \\
\hline
\end{tabular}

\section{Code 2 (Read the choices out loud and list applicable)}

1 Monitoring

2 Calibration of:

a) pesticide application machinery

b) fertilizer application machinery

3 Application of chemicals

4 Recommendations:
a) when to water the crop
b) when to weed
c) when to rotate the crops
d) on quantity and type of fertilizer to be used
e) on quantity and types of chemicals to be used

5 Collection of samples for laboratory analysis

a) Pesticide residue analysis

b) Water analysis

c) Soil analysis

6 Q-GAP

7 GLOBALGAP

8 Other standard (specify)

9 Other, please specify 
C17. Please estimate the total quantity of the following variable inputs you used for your production in the time period March 2010 to the end of February 2011. Please use one sheet per plot.

\begin{tabular}{|c|c|c|c|c|c|c|}
\hline $\begin{array}{l}\text { Inputs } \\
\text { Plot...... } \\
\text { Product......... } \\
\text { Cultivated area } \\
\text {............... }\end{array}$ & $\begin{array}{l}\text { How often do } \\
\text { you apply this } \\
\text { input per } \\
\text { season? }\end{array}$ & $\begin{array}{l}\text { How often do } \\
\text { you apply this } \\
\text { input per year? }\end{array}$ & $\begin{array}{l}\text { Amount of } \\
\text { mixing }\end{array}$ & $\begin{array}{l}\text { Amount used } \\
\text { per rai per } \\
\text { time }\end{array}$ & $\begin{array}{l}\text { Amount } \\
\text { used per plot } \\
\text { per time }\end{array}$ & $\begin{array}{c}\text { Price/ } \\
\text { unit in Baht }\end{array}$ \\
\hline $\begin{array}{ll}1 & \begin{array}{l}\text { Seeds/trees } \\
\text { etc. }\end{array} \\
\end{array}$ & & & & & & \\
\hline a) & & & & & & \\
\hline b) & & & & & & \\
\hline c) & & & & & & \\
\hline 2 Insecticides & & & & & & \\
\hline a) & & & & & & \\
\hline b) & & & & & & \\
\hline c) & & & & & & \\
\hline d) & & & & & & \\
\hline $\begin{array}{ll}3 & \text { Fungicides }\end{array}$ & & & & & & \\
\hline a) & & & & & & \\
\hline b) & & & & & & \\
\hline c) & & & & & & \\
\hline $4 \quad$ Herbicides & & & & & & \\
\hline a) & & & & & & \\
\hline b) & & & & & & \\
\hline c) & & & & & & \\
\hline $5 \quad$ Biocides & & & & & & \\
\hline a) & & & & & & \\
\hline b) & & & & & & \\
\hline c) & & & & & & \\
\hline $6 \quad$ Hormones & & & & & & \\
\hline a) & & & & & & \\
\hline b) & & & & & & \\
\hline $\begin{array}{ll}7 & \begin{array}{l}\text { Chemical } \\
\text { fertilizer }\end{array} \\
\end{array}$ & & & & & & \\
\hline a) & & & & & & \\
\hline b) & & & & & & \\
\hline $8 \begin{array}{l}\text { Organic } \\
\text { fertilizer }\end{array}$ & & & & & & \\
\hline a) & & & & & & \\
\hline b) & & & & & & \\
\hline $9 \begin{array}{l}\text { Other } \\
\text { (specify) }\end{array}$ & & & & & & \\
\hline a) & & & & & & \\
\hline b) & & & & & & \\
\hline
\end{tabular}


C18. Please list all insecticides, fungicides, herbicides used and fill out the information about the pre-harvest interval. The pre-harvest interval is the time between the last chemical application and harvest of the treated crop.

\begin{tabular}{|l|l|l|l|}
\hline Type of chemical & $\begin{array}{c}\text { Treated crop } \\
\text { (product codes) }\end{array}$ & $\begin{array}{c}\text { Do you keep the pre-harvest } \\
\text { interval? } \\
\text { 0 Never / 1 Sometimes / } \\
\text { 2 Always }\end{array}$ & $\begin{array}{c}\text { If yes, how many days do } \\
\text { have to } \\
\text { wait between the last } \\
\text { application and harvesting }\end{array}$ \\
\hline & & & \\
\hline & & & \\
\hline & & & \\
\hline & & & \\
\hline
\end{tabular}

C19. Please estimate the total quantity of the following variable inputs you used for your total agricultural production in the time period March 2010 until the end of February 2011.

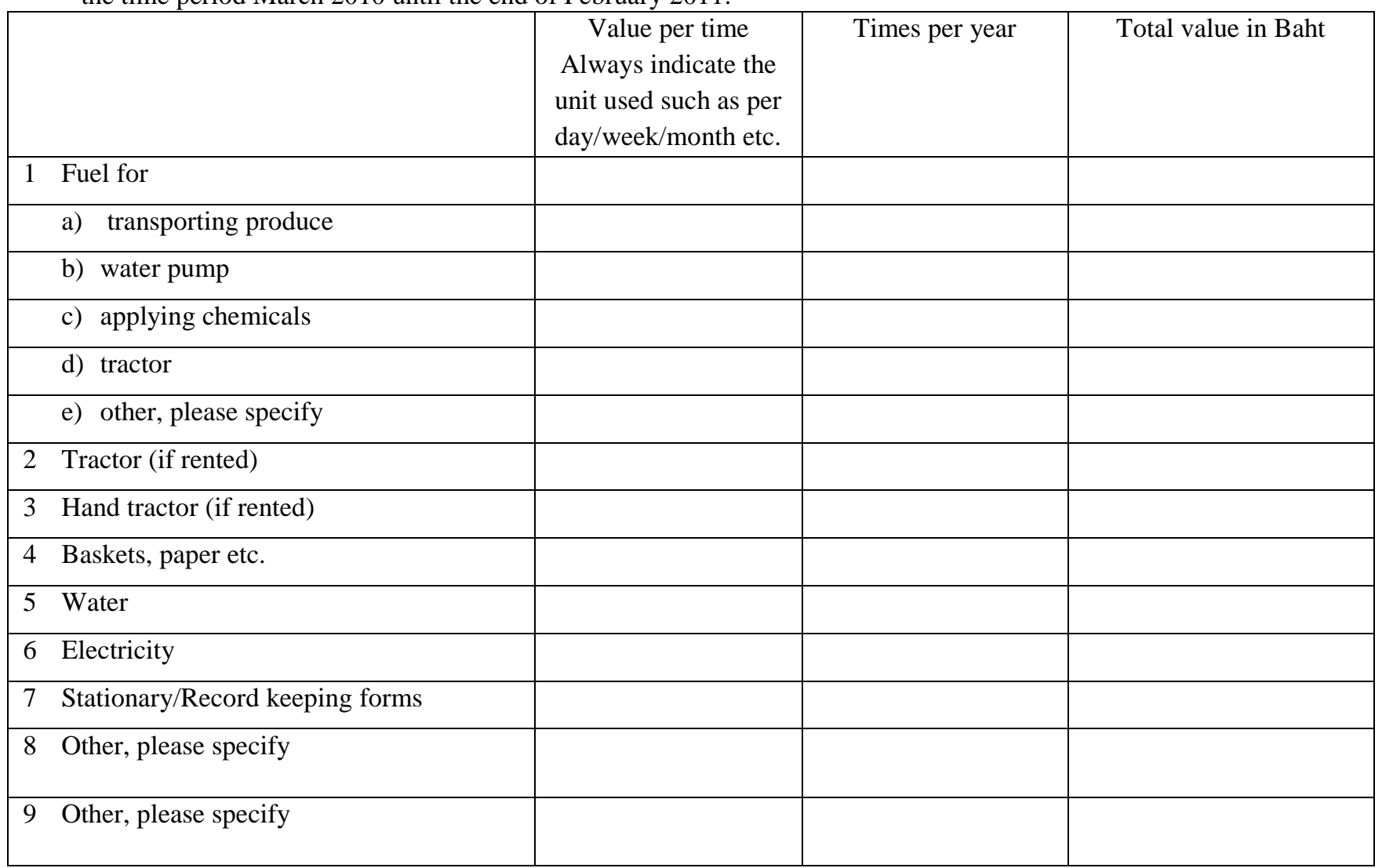


C20. Please tell me about your fixed costs for your total agricultural production. Please only list those items which are used for farming activities or the marketing of produce.

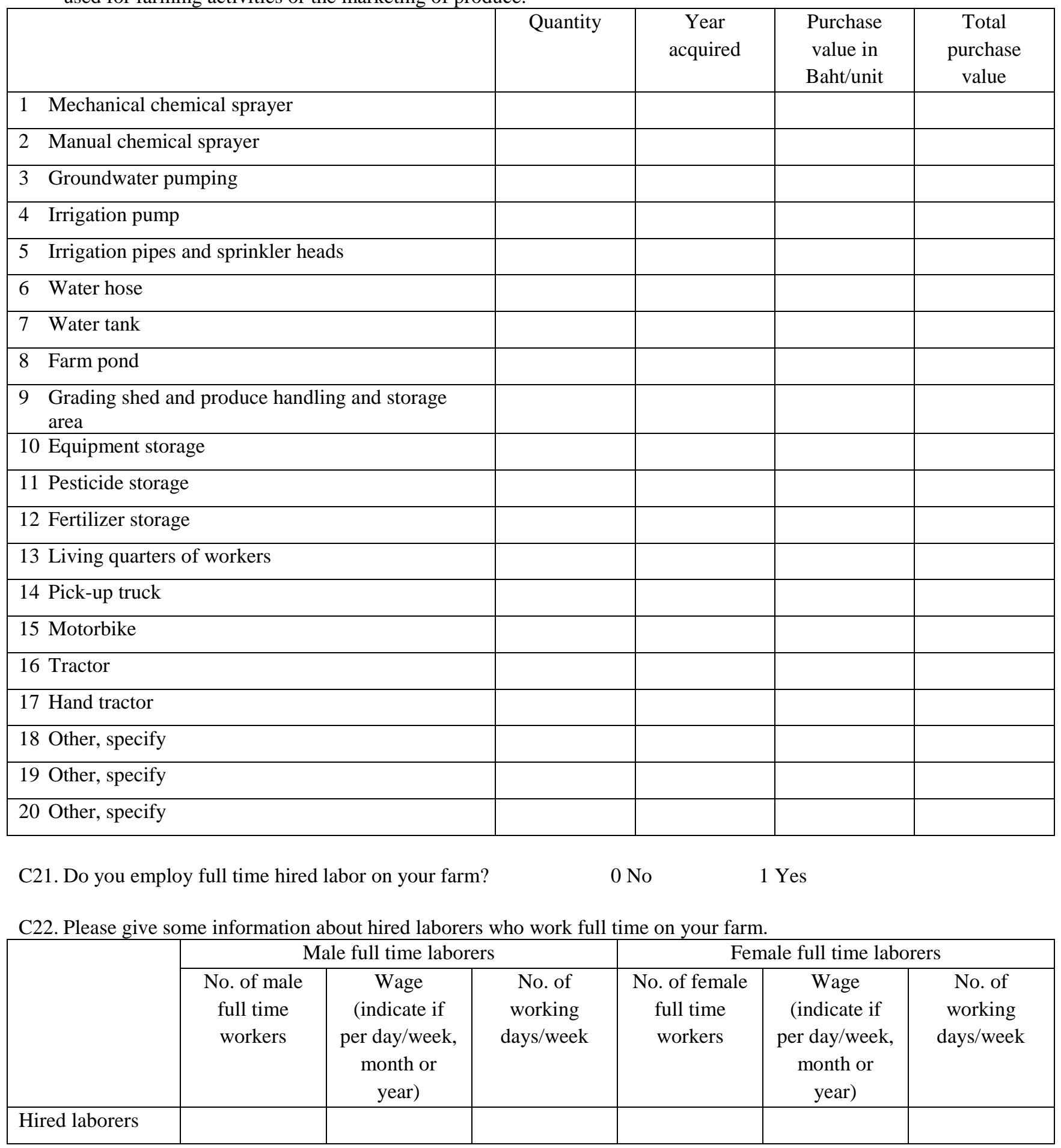


C23. Please give information about last years (i.e., from March 2010 to the end of February 2011) crop management practices and labor required.

\begin{tabular}{|c|c|c|c|c|c|c|c|c|}
\hline \multirow{2}{*}{$\begin{array}{l}\text { Type of } \\
\text { activity } \\
\text { Code } 1\end{array}$} & \multirow{2}{*}{$\begin{array}{l}\text { Product } \\
\text { (product } \\
\text { codes) }\end{array}$} & \multirow{2}{*}{$\begin{array}{l}\text { How often was } \\
\text { the activity } \\
\text { conducted } \\
\text { during the last } \\
\text { year? }\end{array}$} & \multirow{2}{*}{$\begin{array}{l}\text { No. of days } \\
\text { required for } \\
\text { this activity }\end{array}$} & \multirow{2}{*}{$\begin{array}{l}\text { No. of } \\
\text { people } \\
\text { required for } \\
\text { this activity }\end{array}$} & \multicolumn{4}{|c|}{$\begin{array}{c}\text { Number of seasonal hired laborers } \\
\text { required/day }\end{array}$} \\
\hline & & & & & male & $\begin{array}{c}\text { wage/ } \\
\text { day }\end{array}$ & female & $\begin{array}{c}\text { wage/ } \\
\text { day }\end{array}$ \\
\hline & & & & & & & & \\
\hline & & & & & & & & \\
\hline & & & & & & & & \\
\hline & & & & & & & & \\
\hline & & & & & & & & \\
\hline & & & & & & & & \\
\hline & & & & & & & & \\
\hline & & & & & & & & \\
\hline & & & & & & & & \\
\hline
\end{tabular}

\section{Code 1 (Please go through the activities one by one)}

\begin{tabular}{|c|c|c|}
\hline $\begin{array}{ll}1 & \text { Land preparation } \\
2 & \text { Planting } \\
3 & \text { Weeding } \\
4 & \text { Pruning }\end{array}$ & $\begin{array}{ll}5 & \begin{array}{l}\text { Control tree } \\
\text { height }\end{array} \\
6 & \text { Irrigation } \\
7 & \text { Chemical } \\
& \text { application }\end{array}$ & $\begin{array}{ll}8 & \text { Application of fertilizer \& } \\
\text { manure } \\
9 & \text { Harvesting } \\
10 & \text { Packing }\end{array}$ \\
\hline
\end{tabular}

11 Post-harvest activities 12 Other, please specify

C24. Did you own any livestock in the time period March 2010 to the end of February 2011? 0 No 1 Yes

C25. If yes, what livestock did you own in the time period March 2010 to the end of February 2011, what was your income from this livestock and what were the costs?

\begin{tabular}{|c|c|c|c|c|c|c|c|c|c|}
\hline Animal & $\begin{array}{c}\text { How } \\
\text { many } \\
\text { animals } \\
\text { do you } \\
\text { own } \\
\text { today? }\end{array}$ & $\begin{array}{c}\text { How } \\
\text { many } \\
\text { animals } \\
\text { did you } \\
\text { buy? }\end{array}$ & $\begin{array}{c}\text { THB } \\
\text { spend/ } \\
\text { animal? }\end{array}$ & $\begin{array}{c}\text { How } \\
\text { many } \\
\text { animals } \\
\text { did you } \\
\text { sell? }\end{array}$ & $\begin{array}{c}\text { THB } \\
\text { received } \\
\text { per } \\
\text { animal } \\
\text { sold }\end{array}$ & $\begin{array}{l}\text { Number/ } \\
\text { amount } \\
\text { in kg of } \\
\text { sold } \\
\text { products } \\
\text { in the } \\
\text { last } 12 \\
\text { months }\end{array}$ & $\begin{array}{c}\text { Price } \\
\text { received } \\
\text { per } \\
\text { number/ } \\
\text { amount } \\
\text { in kg in } \\
\text { Baht }\end{array}$ & $\begin{array}{c}\text { Amount } \\
\text { spent on } \\
\text { live } \\
\text { stock } \\
\text { feed/ } \\
\text { year }\end{array}$ & $\begin{array}{l}\text { Amount } \\
\text { spent on } \\
\text { veteri- } \\
\text { nary } \\
\text { service/ } \\
\text { year }\end{array}$ \\
\hline \multirow[t]{2}{*}{1 Chicken } & & & & & & Meat: & Meat: & & \\
\hline & & & & & & Eggs: & Eggs: & & \\
\hline 2 Pigs & & & & & & Meat: & Meat: & & \\
\hline \multirow[t]{2}{*}{3 Cattle } & & & & & & Meat: & Meat: & & \\
\hline & & & & & & Milk: & Milk: & & \\
\hline \multicolumn{10}{|l|}{4 Fish } \\
\hline \multicolumn{10}{|l|}{5 Crocodile } \\
\hline \multicolumn{10}{|l|}{6 Buffalo } \\
\hline \multicolumn{10}{|l|}{7 Duck } \\
\hline \multicolumn{10}{|l|}{8 Other } \\
\hline 9 Other & & & & & & & & & \\
\hline
\end{tabular}




\section{Farming practices and chemical management}

D1. How do you determine when to apply chemicals/when would you spray chemicals? (Note: read out loud and encircle all that apply)

0 I don't use chemicals

1 Whenever I see a pest/weeds/fungus disease

2 Depending on the severity of the pest/weeds/fungus disease
3 Using spray calendar/program

4 When advised by input dealer

5 When advised by technical staff. Please specify who
6 When a neighbor sprays

7 When advised by other farmers

8 Buyer comes to apply chemicals

9 Other, please specify

D2. Who usually mixes chemicals at the farm?

1 Household members. Please list the HHIDs of all members mixing chemicals

2 Hired labor, please tick if male or female: $\quad 0$ male 1 female

3 Technical staff from ,please tick if male or female: 0 male 1 female

4 Other, specify

D3. How does the mixer determine the amount of chemical used for mixing chemicals? (Note: read out loud and encircle all that apply)

1 Extension recommendations 3 Following the labels

5 From own experience

7 Other, please specify

2 Instructions by technical staff 4 Recommendation from from other farmers

6 Recommendation from input dealer

D4. What container does the mixer use for mixing chemicals? (Please read out loud and encircle all that apply).
1 Sprayer tank
3 Bucket
6 Boat
2 Special container for mixing
4 Cooking pot chemicals
5 Bathing basin/trough
7 Other, please specify

D5. Who usually applies chemicals at the farm?

1 Household members. Please list the HHIDs of all members mixing chemicals

2 Hired labor, please tick if male or female: $\quad 0$ male 1 female

3 Technical staff from

4 Other, specify

D6. Who usually applies fertilizer at the farm?

1 Household members. Please list the HHIDs of all members mixing chemicals

2 Hired labor, please tick if male or female: $\quad 0$ male 1 female

3 Technical staff from___ please tick if male or female: 0 male 1 female

4 Other, specify

D7. Which of the following clothing does the person applying chemicals wear?

\begin{tabular}{|c|c|}
\hline $\begin{array}{l}\text { Types of protective clothing worn } \\
\text { (Note: please go through the items one by one) }\end{array}$ & $\begin{array}{c}\text { How often is the item used? } \\
0=\text { never } / 1=\text { sometimes } / 2=\text { always }\end{array}$ \\
\hline 1 Rubber boots & \\
\hline 2 Rubber gloves & \\
\hline 3 Face mask & \\
\hline 4 Goggle & \\
\hline 5 Long protective overall & \\
\hline 6 Hat/head scarf & \\
\hline $7 \quad$ Other, please specify & \\
\hline
\end{tabular}


D8. What do you do with empty chemical containers/bottles? (Note: Read the choices out loud and encircle applicable)
1 Sell it to somebody to recycle
2 Bury in the ground
Destroy and burn
4 Wash and use for other purposes, please specify

5 Containers are collected by the government

6 Store it in a bag/box and give to somebody else to dispose of it (e.g. middleman/exporter)

7 Other, please specify

D9. Do you have a pit/specific area for disposing leftover chemicals? 0 No 1 Yes

D10. If yes, please indicate which of the following apply (Note: Read out loud and encircle all that apply)
1 A warning sign is postered on it
3 It is fenced
2 It is covered with logs/timber
4 It is open
5 Other, please specify

D11. Do you have chemical storage? 0 No 1 Yes

D12. If yes,

a) When did you build it?

b) Did you build it to comply with a standard? $\quad 0$ No 1 Yes, please specify (standard codes)

c) Indicate if any of the following applies to your storage (Note: Read out loud and circle all that apply)
1 Has a sign indicating chemical
3 Has a hazard sign on it
5 Nothing storage on the door
4 Has "no admission" on the door
6 Other, please specify

2 Remains locked if not used

D13. Where do you store your chemicals? (Note: Read out loud and circle applicable)
1 Equipment storage
2 Pesticide storage
7 Bedroom
8 Food storage area
3 Shed next to the house
9 Kitchen
4 Pesticide storage of a farmer group/village
10 Animal stall
5 Hanging above the hay in a plastic bag
11 Grading shed
12 Cattle feed storage
6 Living room

13 Beneath the house

14 Box with a lock

15 Old broken fridge

16 Bathroom

17 Other, please specify

D14. Do you have a place to wash hands next to where you store your chemicals?

0 No 1 Yes

D15. If no, how and where can you/farm workers wash your/their hands after handling chemicals?

D16. Do you/farm workers wash hands with soap every time you/they come from the chemical storage or handle chemicals?
1 Never
2 Sometimes
3 Always

D17. Are the following analyses regularly conducted at your farm?
a) Pesticide residue analyses?
0 No 1 Yes
b) Soil analysis?
0 No 1 Yes
c) Irrigation water analysis?
0 No 1 Yes
d) Water used for post-harvest washing?
0 No 1 Yes 
D18. If yes: (Note: go through the types of analyses one by one)

\begin{tabular}{|l|l|l|l|l|}
\hline \multicolumn{1}{|c|}{ Type of analysis } & $\begin{array}{c}\text { How often is } \\
\text { the analysis } \\
\text { conducted? } \\
\text { Code 1 }\end{array}$ & $\begin{array}{c}\text { Who pays for } \\
\text { the analysis? } \\
\text { Code 2 }\end{array}$ & $\begin{array}{c}\text { Costs per analysis if } \\
\text { the farmer pays } \\
\text { him/herself }\end{array}$ & $\begin{array}{c}\text { Who collects the } \\
\text { samples? } \\
\text { Code 2 }\end{array}$ \\
\hline Pesticide residue analysis & & & & \\
\hline Soil analysis & & & & \\
\hline Irrigation water analysis & & & & \\
\hline Water used for post-harvest washing & & & & \\
\hline
\end{tabular}

Code 1 (Let the farmer answer and list applicable. If necessary read the choices out loud)

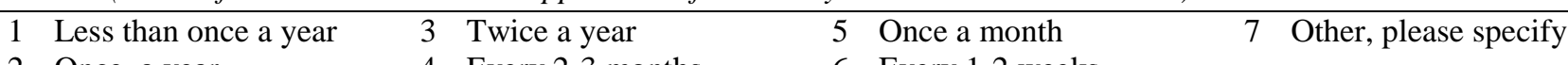

2 Once a year 4 Every 2-3 months 6 Every 1-2 weeks

\begin{tabular}{|c|c|c|c|}
\hline \multicolumn{4}{|c|}{ Code 2 (Let the farmer answer and list applicable. If necessary read the choices out loud) } \\
\hline 1 Myself & 4 DOA/DOAE & 7 & NGO/donor (specify) \\
\hline Exporter/buyer (specify) & Farmer group/co-op (specify) & 8 & Department of Land Development \\
\hline 3 Collector/middleman & University (specify) & 9 & Other, please specify \\
\hline
\end{tabular}

D19. Do you apply IPM at your farm? Please explain IPM to farmers. $\quad 0$ No 1 Yes

D20. If yes, please list the IPM techniques which you apply at your farm.
1 Scouting
2 Studying the life cycle
4 Use of row covers/fruit
7 Use of insect traps covers of insects
5 Trap cropping
8 Use of parasites and predators
10 Use of biocides
11 Other (specify)

6 Intercropping

9 Handpicking

3 Maintain plant vigor

D21. Do you use/apply any of the following practices/measures? Please encircle.
1 Crop rotation
6 Planting along contour lines
2 Terraces /Stone barriers
3 Living barriers
7 Drainage ditches
4 Minimum or zero tillage
8 Cover crops
5 Trees or hedges/agro forest
9 Mulching/ Covering the field with crop residues
10 Other, please specify

D22. Do workers handling chemicals regularly go to health checks? 0 No 1 Yes If yes,

\begin{tabular}{|c|c|c|c|}
\hline How many workers go? & $\begin{array}{c}\text { How often do they go? } \\
\text { Code } 1\end{array}$ & $\begin{array}{c}\text { Who pays for the health } \\
\text { check? Code2 }\end{array}$ & Costs/time/worker \\
\hline & & & \\
\hline
\end{tabular}

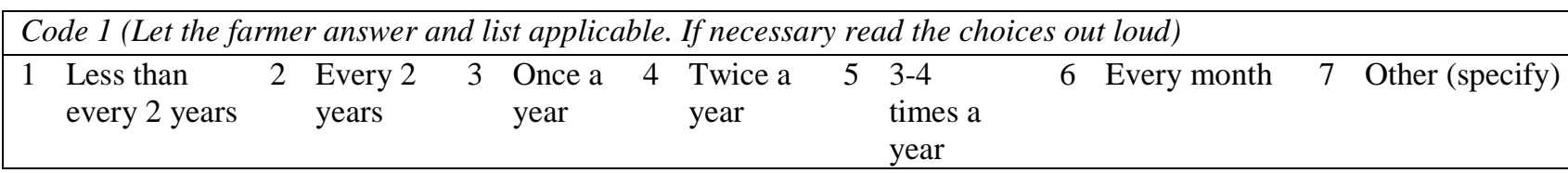

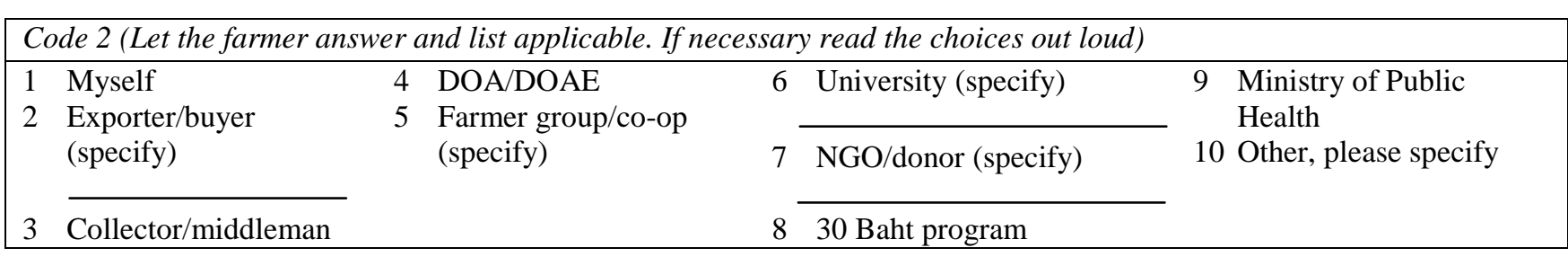

D23. Do you have a first aid kit at your farm? $\quad 0$ No 1 Yes 
D24. Please indicate how frequently someone in your family experiences the following acute symptoms after handling or applying chemicals? (Note: go through the symptoms one by one)

\begin{tabular}{|ll|c|c|c|}
\hline \multicolumn{1}{|c|}{ Symptom } & Never & Sometimes & Often \\
\hline 1 & Dizziness & $\square$ & $\square$ & $\square$ \\
\hline 2 & Vomiting & $\square$ & $\square$ & $\square$ \\
\hline $3 \quad$ Nausea & $\square$ & $\square$ & $\square$ \\
\hline 4 Nose bleeding & $\square$ & $\square$ & $\square$ \\
\hline 5 & Blurred vision & $\square$ & $\square$ & $\square$ \\
\hline 6 & Common colds & $\square$ & $\square$ & $\square$ \\
\hline 7 Headache & $\square$ & $\square$ & $\square$ \\
\hline 8 & Eye irritation & $\square$ & $\square$ & $\square$ \\
\hline 9 & Skin irritation & $\square$ & $\square$ & $\square$ \\
\hline 10 Stomach irritation & $\square$ & $\square$ & $\square$ \\
\hline 11 Other (specify) & $\square$ & $\square$ \\
\hline
\end{tabular}

D25. Is there a toilet accessible for the farm workers at your farm or at least 500m from your farm?

0 No

1 Yes. If yes, please specify what kind of toilet can be used:
a) Toilet in the farmer's private home
b) Neighbor's toilet
c) Separate toilet on the plot
d) Other, please specify

D26. Are all plots marked with a plot sign? 0 No 1 Yes

D27. If yes, what is indicated on the plot marker? (Note: read out loud and encircle all that apply)
1 Plot name
6 Harvesting date
2 Size of the plot
7 Chemicals used on the plot
3 Type of plants
8 Pre-harvest interval
4 Code
9 Name of the plot owner
5 Planting date
10 Other /specify

D28. Do you keep records? $\quad 0$ No 1 Yes

D29. If yes, please fill out the following table (Note: go through the items one by one)

\begin{tabular}{|c|c|c|}
\hline Do you keep records about? & $\begin{array}{c}0=\text { No } \\
1=\text { Yes }\end{array}$ & $\begin{array}{l}\text { Since when do you keep these } \\
\text { records? }\end{array}$ \\
\hline 1 Crop rotation & & \\
\hline 2 Growing and harvesting calendar & & \\
\hline 3 Chemical and fertilizer stocks & & \\
\hline 4 Calibration of chemical equipment & & \\
\hline 5 Chemical application records & & \\
\hline $\begin{array}{ll}6 & \text { Fertilizer application records }\end{array}$ & & \\
\hline $7 \quad$ Water application records & & \\
\hline 8 Hygiene and cleaning records & & \\
\hline 9 Sales records & & \\
\hline 10 Other, please specify & & \\
\hline 11 Other, please specify & & \\
\hline
\end{tabular}


D30. Who keeps the records? Please encircle all that apply

1 Household members. Please list the HHIDs of all members keeping records

2 Hired labor, please tick if male or female: 0 male 1 female

3 Technical staff from ___ please tick if male or female: 0 male 1 female

4 Other, specify

D31. How many times during one month are records filled out?

D32. How many minutes are spent on record keeping per time?

\section{E. Compliance with standards}
E1. Do you know GAP
0 No
1 Yes

E2. If yes, who advises you on GAP/where do you get information on GAP?
1 Extension officer from DOA/DOAE
2 Kaset Tambon/Amphoe/Dschangwat
9 Farmers meeting (farmer group/co-op)
3 University farm advisors(specify)
10 Village head
4 NGO/donor (specify)
5 Exporter/manufacturer (specify)
6 Collector/middleman
7 Adviser from the Ministry of Public Health
11 Radio/TV
12 Newspaper/magazine
13 Royal project
8 Other farmers
14 Chiang Rai Horticultural Research Centre
15 BAAC
16 Other (specify)

E3. Do you know any GAP standards?

0 No

1 Yes

E4. If yes, which standards do you know?

1 Q-GAP (GAPThai, from DOA)

2 GLOBALGAP

3 Tesco Nature's Choice (TNC)

4 Carrefour Quality Line Organic Vegetable (CQL)

5 Field \& Fork (Marks \& Spencer)

6 Other (specify)

E5. Have you ever been trained by Kasetsart University about Western GAP, KU GAP, KU TG or any other GAP standards? 0 No 1 Yes

E5.1 If yes, have you implemented the KU GAP requirements on your farm? $\quad 0$ No 1 Yes

E5.2 If yes, do you still practice the KU GAP requirements on your farm? $\quad 0$ No 1 Yes

E6. Do you know organic production? $\quad 0$ No 1 Yes

E7. If yes, who advises you on organic production/where do you get information on organic production? Please read choices out loud.

1 Extension officer from DOA/DOAE

2 Kaset Tambon/Amphoe/Dschangwat

3 University farm advisors(specify)

4 NGO/donor (specify)

5 Exporter/manufacturer (specify)

6 Collector/middleman

7 Adviser from the Ministry of Public Health

8 Other farmers

9 Farmers meeting (farmer group/co-op)

10 Village head

11 Radio/TV

12 Newspaper/magazine

13 Royal project

14 Chiang Rai Horticultural Research Centre

15 BAAC

16 Other (specify) 
E8. Do you know any organic production standards?

0 No

1 Yes

E9. If yes, which standards do you know? Please encircle all standards you know
1 National Organic Program (NOP) Thailand
4 IFOAM's Organic Guarantee System (OGS)
2 Organic Agriculture Certification Thailand (ACT)
3 Japanese Agricultural Standard (JAS)
5 EU organic standard
6 National Organic Program (USDA)

7 Other, please specify

E10. Are you certified against a standard? 0 No 1 Yes

E11. If yes,

\begin{tabular}{|l|c|c|c|c|c|}
\hline $\begin{array}{c}\text { against which } \\
\text { standard? }\end{array}$ & $\begin{array}{c}\text { Are you certified } \\
1=\text { individually } \\
\text { or 2= in a group? }\end{array}$ & $\begin{array}{c}\text { Since when } \\
\text { are you } \\
\text { certified? }\end{array}$ & $\begin{array}{c}\text { For which } \\
\text { products are } \\
\text { you certified? } \\
\text { (Product } \\
\text { codes) }\end{array}$ & $\begin{array}{c}\text { Size of the } \\
\text { certified area }\end{array}$ & $\begin{array}{c}\text { Who supported } \\
\text { standard } \\
\text { implementation at your } \\
\text { farm? Code 1 }\end{array}$ \\
\hline & & & & & \\
\hline & & & & & \\
\hline
\end{tabular}

\begin{tabular}{|c|c|c|c|c|c|}
\hline 0 & Nobody & 4 & Kaset tambon/amphoe & 8 & Royal Project \\
\hline 1 & Exporter/buyer (specify) & 5 & University (specify) & 9 & Chiang Rai Horticultural \\
\hline 2 & Collector/middleman & 6 & Farmer group/co-op & & Research Centre \\
\hline 3 & DOA/DOAE & 7 & NGO/donor (specify) & 10 & Other (specify) \\
\hline
\end{tabular}
E12. Are you in the process of certification against a standard?
0 No
1 Yes

(Note: the farmer has started implementing a standard on his/her farm and plans to get a certificate soon)

E13. If yes,

\begin{tabular}{|c|c|c|c|c|c|}
\hline $\begin{array}{c}\text { against which } \\
\text { standard? } \\
\text { Standard codes }\end{array}$ & $\begin{array}{c}\text { Do you plan to } \\
\text { become certified } \\
1=\text { individually } \\
\text { or } 2=\text { in a group? }\end{array}$ & $\begin{array}{c}\text { When do you } \\
\text { plan to } \\
\text { become } \\
\text { certified? }\end{array}$ & $\begin{array}{c}\text { For which } \\
\text { products do you } \\
\text { plan to become } \\
\text { certified? } \\
\text { Product codes }\end{array}$ & $\begin{array}{c}\text { Size of the } \\
\text { area to be } \\
\text { certified }\end{array}$ & $\begin{array}{c}\text { Who supports } \\
\text { standard } \\
\text { implementation at } \\
\text { your farm? } \\
\text { Code } 1\end{array}$ \\
\hline & & & & & \\
\hline
\end{tabular}

\begin{tabular}{|llrlll|}
\hline \multicolumn{2}{|l|}{ Code 1 (Note: Read the choices out loud and list all that apply) } & \\
\hline 0 & Nobody & 4 & Kaset tambon/amphoe & 8 & Royal Project \\
1 & Exporter/buyer (specify) & 5 & University (specify) & 9 Chiang Rai Horticultural Research \\
2 & Collector/middleman & 6 & Farmer group/co-op & Centre \\
3 & DOA/DOAE & 7 & NGO/donor (specify) & 10 Other (specify) \\
\hline
\end{tabular}


E14. If you are certified against a standard or in the process of certification, why did you/do you want to have a certificate? (Note: read the choices out loud and encircle all that apply. If the farmer has more than one standard, ask for the standard which is not Q-GAP).

Standard:

1 Buyer asked me to implement it. Please specify which buyer

2 I wanted to increase the quality of the product.

3 The buyer frequently rejected my produce due to food safety issues and I wanted to decrease the rate of rejection.

4 Buyer offered a purchase guarantee for certified produce.

5 Buyer offered a price premium for certified produce.

6 I expected that I could increase my sales to high-value markets where price premiums are paid.

7 I wanted to decrease the costs for chemicals.

8 I wanted to enhance my reputation.

9 I wanted to enhance my bargaining power.

10 I expected that finding buyers is much easier when I am certified.

11 I expected better management practices which might increase the profitability.

12 I wanted to implement the standard because it is good for my family's and farm workers' health.

13 I wanted to increase my knowledge on chemical use.

14 Other, please specify

E15. Have you ever tried to implement a standard at your farm with the goal to become certified but not completed the implementation process? 0 No 1 Yes

E16. If yes, please specify which standard and why did you not complete standard implementation at your farm

\begin{tabular}{|c|c|c|c|c|}
\hline $\begin{array}{c}\text { Standard } \\
\text { (standard codes) }\end{array}$ & $\begin{array}{c}\text { For which } \\
\text { product(s) did you } \\
\text { want the } \\
\text { certificate? } \\
\text { Product codes }\end{array}$ & $\begin{array}{c}\text { When did you try to } \\
\text { implement the } \\
\text { standard? }\end{array}$ & $\begin{array}{c}\text { Why didn't you } \\
\text { complete standard } \\
\text { implementation at your } \\
\text { farm (Code 1) }\end{array}$ & $\begin{array}{c}\text { Who supported standard } \\
\text { implementation at your } \\
\text { farm? (Code 2) }\end{array}$ \\
\hline & & & & \\
\hline & & & & \\
\hline
\end{tabular}

Code 1 (Note: Read the choices out loud and list all that apply)

1 The investment costs were too high.

2 The additional workload was too high.

3 I didn't understand many of the standard requirements.

4 Record keeping was too difficult.

5 I wanted to implement the standard and become certified, but my buyer/advisor decided I am not ready yet. Please specify who decided.
6 There wasn't enough support available.

7 First, I was supported by but then they stopped to support me.

8 There are no price premiums for certified produce.

9 I changed my buyer and the new buyer doesn't need the standard.

10 Other, please specify

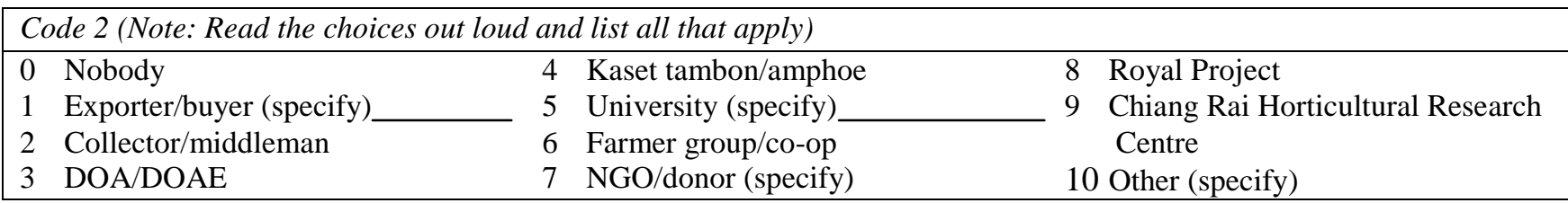

E17. Were you certified against a standard in the past, but then left the standard?

0 No 1 Yes 
E18. If yes, please specify

\begin{tabular}{|c|c|c|c|c|c|c|c|}
\hline $\begin{array}{c}\text { Standard } \\
\text { (standard codes) }\end{array}$ & $\begin{array}{c}\text { Product you } \\
\text { had a } \\
\text { certificate for } \\
\text { (product codes) }\end{array}$ & $\begin{array}{c}\text { Size of the } \\
\text { area that } \\
\text { was } \\
\text { certified }\end{array}$ & $\begin{array}{c}\text { Who supported } \\
\text { standard } \\
\text { implementation } \\
\text { at your farm? } \\
\text { Code 1 }\end{array}$ & $\begin{array}{c}\text { Were you } \\
\text { certified } \\
1=\text { individually } \\
\text { or } \\
2=\text { in a group? }\end{array}$ & $\begin{array}{c}\text { Month/ } \\
\text { year you } \\
\text { first } \\
\text { became } \\
\text { certified }\end{array}$ & $\begin{array}{c}\text { Month/ } \\
\text { year you } \\
\text { left the } \\
\text { standard }\end{array}$ & $\begin{array}{c}\text { Reason for } \\
\text { leaving the } \\
\text { standard } \\
\text { Code 2 }\end{array}$ \\
\hline & & & & & & & \\
\hline & & & & & & & \\
\hline
\end{tabular}

Code 1 (Note: Read the choices out loud and list all that apply)

\begin{tabular}{|c|c|c|c|}
\hline 0 & Nobody & Kaset tambon/amphoe & Royal Project \\
\hline 1 & Exporter/buyer (specify). & University (specify) & Chiang Rai Horticultural Research \\
\hline 2 & Collector/middleman & Farmer group/co-op & Centre \\
\hline 3 & DOA/DOAE & NGO/donor (specify) & 10 Other (specify) \\
\hline
\end{tabular}

Code 2 (Note: Read the choices out loud and list all that apply)

\begin{tabular}{|c|c|c|}
\hline High costs & 6 Difficulties in record keeping & 10 I changed the crop \\
\hline Absence of a price premium & 7 High additional workload & $11 \mathrm{My}$ farm is too small for the standard to \\
\hline The price premium was too & I didn’t need it anymore & be economically \\
\hline $\begin{array}{l}\text { low to cover the additional } \\
\text { costs }\end{array}$ & $\begin{array}{l}9 \text { I changed my buyer and the new } \\
\text { buyer didn't need the standard }\end{array}$ & 12 Other, please specify \\
\hline Absence of support & & \\
\hline Discontinuation of support & & \\
\hline
\end{tabular}


Note: Only ask this section if the farmer is certified against a standard, in the process of certification or has disadopted a standard. Otherwise continue with question E21.

E19. Did you have any investment costs for standard implementation at your farm or did somebody provide farm infrastructure and farm equipment for you to adopt a standard?

$$
0 \text { No } \quad 1 \text { Yes }
$$

E20. If yes, please tell us about the investments you made and items provided for standard adoption

\begin{tabular}{|c|c|c|c|c|c|}
\hline \multirow[t]{19}{*}{$\begin{array}{l}\text { Standard } \\
\text { that was } \\
\text { invested in } \\
\text { (standard } \\
\text { codes) }\end{array}$} & Investment items & $\begin{array}{c}\text { Was the item paid } \\
\text { for/provided by others? } \\
0 \text { No / } 1 \text { Yes } \\
\text { If yes, please specify by } \\
\text { whom } \\
\text { Code } 1\end{array}$ & $\begin{array}{l}\text { Amount } \\
\text { invested by } \\
\text { the farmer } \\
\text { per item }\end{array}$ & $\begin{array}{c}\text { Did you } \\
\text { have to take } \\
\text { out a loan } \\
\text { for the } \\
\text { investment? } \\
0=\text { No / } \\
1=\text { Yes }\end{array}$ & $\begin{array}{c}\text { If you had to } \\
\text { take out a loan, } \\
\text { where did you } \\
\text { obtain the loan? } \\
\text { Code } 2\end{array}$ \\
\hline & $\begin{array}{l}1 \text { Building/upgrading of } \\
\text { pesticide storage }\end{array}$ & & & & \\
\hline & $\begin{array}{l}2 \text { Building/upgrading of } \\
\text { fertilizer storage }\end{array}$ & & & & \\
\hline & $\begin{array}{l}\text { Building/upgrading living } \\
\text { quarters of workers and } \\
\text { resting area for workers }\end{array}$ & & & & \\
\hline & $\begin{array}{l}4 \text { Toilet and hand washing } \\
\text { facilities }\end{array}$ & & & & \\
\hline & 5 Sprayer equipment & & & & \\
\hline & $\begin{array}{l}6 \text { Chemical mixing area and } \\
\text { disposal site }\end{array}$ & & & & \\
\hline & $\begin{array}{l}7 \text { Separate storage for empty } \\
\text { chemical containers }\end{array}$ & & & & \\
\hline & 8 Protective Clothing & & & & \\
\hline & $\begin{array}{l}9 \text { Separate storage for all } \\
\text { protective clothing }\end{array}$ & & & & \\
\hline & 10 Collection point & & & & \\
\hline & 11 Grading shed/area & & & & \\
\hline & 12 First aid kit & & & & \\
\hline & 13 Plot markers & & & & \\
\hline & 14 Signs and poster & & & & \\
\hline & 15 Waste bins & & & & \\
\hline & 16 Training fees & & & & \\
\hline & 17 Other, specify & & & & \\
\hline & 18 Other, specify & & & & \\
\hline
\end{tabular}

Code 1 (Let the farmer answer and select the code. If necessary, read the choices out loud)

1 Exporter/buyer (specify)

2 Collector/middleman

3 DOA/DOAE

4 Farmer group/co-op (specify)

5 University (specify)

6 NGO/donor (specify)

7 Other, please specify

Code 2 (Let the farmer answer and select the code. If necessary, read the choices out loud)

1 Bank for agriculture and agricultural cooperatives (BAAC)

2 Other banks/Financial institute

3 Cooperative/Farmer's group

4 Village and city fund

5 Exporter/processor enterprise (specify)
6 Middleman/collector

7 Money lender

8 Neighbor/relative/friend

9 Other, please specify 
E21. Do you plan to adopt a standard in the future? 0 No (please continue with E24) 1 Yes

(Note: answer this question only for standards for which you are not yet in the process of standard implementation)

E22. If yes, please specify standard (standard codes)?

E23. If yes, please explain why you want to adopt it

E24. If you don't have a standard and you don't want to implement a standard, why don't you want a standard?

\section{F. Access to information and services}

F1. Are you or another household member a member of a farmer group, cooperative or any other organization? 0 No 1 Yes

F2. If yes, please fill out the following table

\begin{tabular}{|c|c|c|c|c|c|}
\hline $\begin{array}{l}\text { Type of group } \\
1 \text { Farmer group } \\
2 \text { Co-op } \\
3 \text { Other } \\
\text { (specify) }\end{array}$ & $\begin{array}{l}\text { Who is a } \\
\text { member } \\
\text { (Member } \\
\text { I.D.) }\end{array}$ & $\begin{array}{l}\text { Since which } \\
\text { year is the } \\
\text { person a } \\
\text { member? }\end{array}$ & $\begin{array}{l}\text { What is its } \\
\text { purpose? } \\
\text { Code } 1\end{array}$ & $\begin{array}{l}\text { How often did the } \\
\text { member participate in } \\
\text { meetings of the } \\
\text { organization in the time } \\
\text { period March } 2010 \text { to } \\
\text { February 2011? }\end{array}$ & $\begin{array}{l}\text { Does the member hold } \\
\text { any position in the } \\
\text { organization? } \\
0 \text { No / } 1 \text { Yes } \\
\text { If yes, please specify }\end{array}$ \\
\hline & & & & & \\
\hline & & & & & \\
\hline & & & & & \\
\hline & & & & & \\
\hline
\end{tabular}

Code 1 (Read the choices out loud and list all that apply)

1 Provision of inputs 5 Marketing of farmers produce (specify

2 Provision of credits

3 Provision of saving accounts

4 Renting out of farmers equipment products)

6 Certification against a standard (specify)

7 Information on market prices
8 Water user group

9 Produce fertilizer/biocides

10 Processing product, specify

11 Other, please specify 
F3. Do you have access to extension services?

0 No 1 Yes

F4. If yes, what kind of information is provided and how often?

\begin{tabular}{|l|l|l|}
\hline Service provider & $\begin{array}{c}\text { Which kind of information is } \\
\text { provided? Code } 1\end{array}$ & $\begin{array}{c}\text { How often do you meet? } \\
\text { Code2 }\end{array}$ \\
\hline $1 \quad$ Farm advisor from DOAE /DOA & & \\
\hline $3 \quad$ University extension agent please specify & & \\
\hline $4 \quad$ Farm advisor from a farmer group/co-op & & \\
\hline 5 Royal project & & \\
\hline $6 \quad$ Land Development Department & & \\
\hline $7 \quad$ Chemical shop & & \\
\hline 8 NGO/donor & & \\
\hline $9 \quad$ BAAC & & \\
\hline 10 Other, please specify & & \\
\hline 11 Other, please specify & & \\
\hline
\end{tabular}

Code 1 (Read the choices out loud and list all that apply)

1 Information on chemicals and 5 Information on prices, buyers and chemical use

2 Information on Integrated Pest Management

3 Information on fertilizer use

4 Information on production techniques marketing

6 Information on Q-GAP

7 Information on other standards

8 Organic production techniques
9 Soil conservation

10 Water conservation

11 Other, please specify

\begin{tabular}{|c|c|c|c|c|}
\hline \multicolumn{5}{|c|}{ Code 2 (Let the farmer answer and select the code) } \\
\hline 1 Less than once a year & 4 Every three months & Every two to three weeks & 9 & More than once a \\
\hline Once a year & Every two months & Once a week & & week \\
\hline Two to three times a year & Once a month & & 10 & Other, please specify \\
\hline
\end{tabular}


F5. How often did you or any other household member or hired laborers participate in trainings in the last 3 years?

\begin{tabular}{|c|c|c|c|c|c|c|c|c|c|}
\hline ID & $\begin{array}{c}\text { No. } \\
\text { trainings }\end{array}$ & ID & $\begin{array}{c}\text { No. } \\
\text { trainings }\end{array}$ & ID & $\begin{array}{c}\text { No. } \\
\text { trainings }\end{array}$ & ID & $\begin{array}{c}\text { No. } \\
\text { trainings }\end{array}$ & $\begin{array}{c}\text { Number } \\
\text { of hired } \\
\text { laborers }\end{array}$ & $\begin{array}{c}\text { Number } \\
\text { of } \\
\text { trainings }\end{array}$ \\
\hline & & & & & & & & & \\
\hline
\end{tabular}

F6. In which of the following trainings subjects did you, other household members, hired laborers took part?

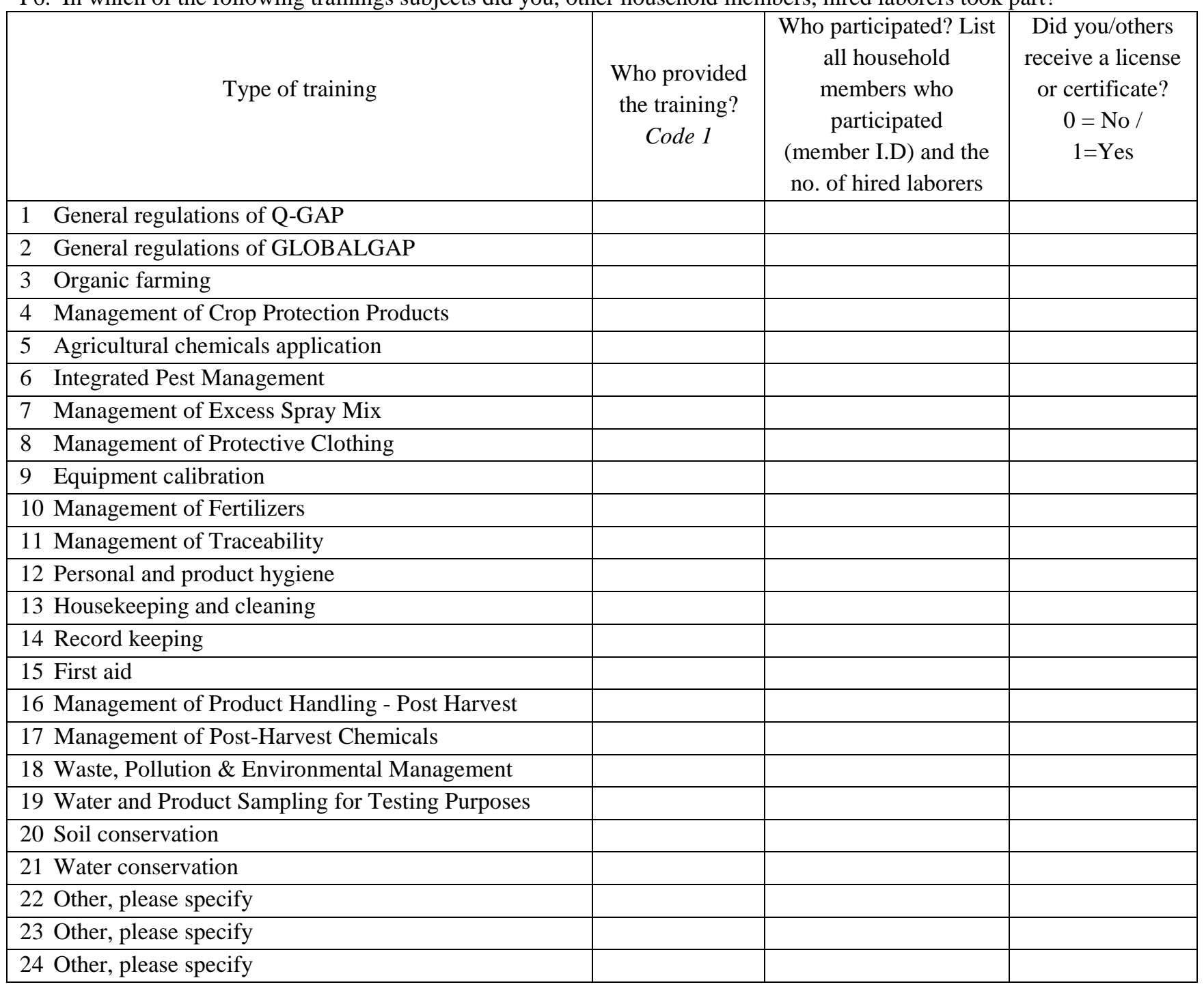

\section{Code 1}

\section{DOA/DOAE}

2 Kaset Tambon/ Amphoe/Dschangwat

3 University (specify)
4 Exporter/buyer (specify)
5 NGO/donor (specify)

$\begin{array}{ll}6 & \text { Farmer group/co-op } \\ 7 & \text { Land Development } \\ & \text { Department } \\ 8 & \text { Chemical shop }\end{array}$

6 Farmer group/co-op

9 BAAC

10 Other (specify)

8 Chemical shop

F7. If you had to borrow money for example to buy a pick-up truck, a motorcycle or to pay a hospital bill, would somebody give you a loan? 0 No 1 Yes 
F8. If yes, where could you obtain credit? Please encircle

1 I could obtain formal credit from
a) Bank for agriculture and agricultural cooperatives
b) Other banks/Financial institute
c) Cooperative/Farmer's group
d) Village and city fund
e) Other, please specify

2 I could obtain informal credit from

a) Exporter/processor enterprise (specify)

b) Middleman/collector

c) Money lender

d) Neighbor/relative/friend

e) Other, please specify

F9. Do you use the internet?

0 No 1 Yes, since (year)

F10. If yes, for what purpose do you use the internet?

1 To contact buyers

4 For banking and payments

2 To contact extension services

3 To inform myself about market prices

5 Other, specify

F11. Do you own a mobile phone?

0 No 1 Yes, since (year)

F12. If yes, for which purposes do you use the mobile phone?

1 To contact buyers

2 To contact extension services

4 For banking and payments

3 To inform myself about market prices

5 Other, specify

\section{G. Assets and dwelling related indicators}

G1. Which of the following assets does the household own?

\begin{tabular}{|ll|l|l|l|}
\hline & No. owned & \multicolumn{1}{|c|}{ Asset } & No. owned \\
\hline 1 & Cars (except pick-up trucks) & & 8 Telephone & \\
\hline 2 & TV & & 9 Mobile phone & \\
\hline 3 & Radios & & 10 Air con & \\
\hline 4 & CD Player & & 11 Refrigerator & \\
\hline 5 & DVD Player & 12 Gas stove & \\
\hline 6 & Satellite dish & & 13 Microwave & \\
\hline 7 Washing machine & & 14 Other & \\
\hline
\end{tabular}

Note: Information should be collected about the dwelling in which the family currently resides.

G2. What is the ownership status of dwelling? The status is owned if any member who lives in the household is the owner.

1 Owned (with title)

2 Owned (without title)
3 Given by relative or other to use

4 Rented

G3. What type of roofing material is used in main house?
1 Brick or stone
3 Bamboo
5 Clay bricks
7 Tiles
2 Corrugated iron
4 Straw
6 Concrete
8 Other (specify)

G4. What type of exterior walls does the dwelling have?
1 Concrete
3 Metal
2 Wood
4 Bamboo

5 Other (specify)

G5. What type of flooring does the dwelling have?
1 Earth
3 Bamboo
5 Wood
7 Stones
2 Cement
4 Cement with additional covering
6 Ceramics 


\section{H. Household expenditure on food and food consumption}

H1. How much of the following items did you consume in the last seven days in your household? First ask for quantity and market price. Only if the farmer cannot answer, ask for the value of the consumed products. Please stress out that products consumed from own production shall be included as well!

\begin{tabular}{|c|c|c|c|c|c|c|c|}
\hline & $\begin{array}{c}\text { Quantity } \\
\text { (always } \\
\text { indicate the } \\
\text { unit and if per } \\
\text { week/ } \\
\text { day/month etc.) }\end{array}$ & $\begin{array}{c}\text { Market } \\
\text { price in } \\
\text { Baht/unit }\end{array}$ & $\begin{array}{l}\text { Total } \\
\text { value }\end{array}$ & & $\begin{array}{c}\text { Quantity } \\
\text { (always indicate } \\
\text { the unit and if per } \\
\text { week/day/month } \\
\text { etc.) }\end{array}$ & $\begin{array}{c}\text { Market } \\
\text { price in } \\
\text { Baht/unit }\end{array}$ & $\begin{array}{l}\text { Total } \\
\text { value }\end{array}$ \\
\hline $\begin{array}{l}\text { Rice and other } \\
\text { staple }\end{array}$ & & & & $\begin{array}{l}\text { Oil, fish } \\
\text { sauce, etc }\end{array}$ & & & \\
\hline $\begin{array}{l}\text { Meals bought } \\
\text { outside }\end{array}$ & & & & Tobacco & & & \\
\hline Fresh fruits & & & & Sweets & & & \\
\hline Vegetables & & & & $\begin{array}{l}\text { Non- } \\
\text { alcoholic } \\
\text { beverages }\end{array}$ & & & \\
\hline $\begin{array}{l}\text { Fresh Meat and } \\
\text { Fish }\end{array}$ & & & & $\begin{array}{l}\text { Alcoholic } \\
\text { beverages }\end{array}$ & & & \\
\hline $\begin{array}{l}\text { Dairy Products } \\
\text { and Eggs }\end{array}$ & & & & $\begin{array}{l}\text { Other } \\
\text { (specify) }\end{array}$ & & & \\
\hline $\begin{array}{l}\text { Preserved food, } \\
\text { esp. fish }\end{array}$ & & & & $\begin{array}{l}\text { Other } \\
\text { (specify) }\end{array}$ & & & \\
\hline $\begin{array}{l}\text { Herbs and } \\
\text { spices }\end{array}$ & & & & $\begin{array}{l}\text { Other } \\
\text { (specify) }\end{array}$ & & & \\
\hline
\end{tabular}

H2. Which of these statements best describes the food eaten in your household in the last 12 months? Please encircle

1 Enough of the kinds of food (I/we) want to eat

2 Enough, but not always the kinds of food (I/we) want

3 Enough, but not always the quality of the food (I/we) want

4 Sometimes not enough to eat

5 Often not enough to eat

H3. Please indicate how frequently someone in your family experiences the following symptoms after eating. (Note: go through the symptoms one by one)

\begin{tabular}{|ll|c|c|c|}
\hline \multicolumn{1}{|c|}{ Symptom } & Never & Sometimes & Often \\
\hline 1 & Diarrhea & $\square$ & $\square$ & $\square$ \\
\hline 2 & Crampy stomach pain & $\square$ & $\square$ & $\square$ \\
\hline 3 & Vomiting & $\square$ & $\square$ & $\square$ \\
\hline 4 & Nausea & $\square$ & $\square$ & $\square$ \\
\hline 5 & Fever & $\square$ & $\square$ & $\square$ \\
\hline 6 & Other (specify) & $\square$ & $\square$ & $\square$ \\
\hline
\end{tabular}




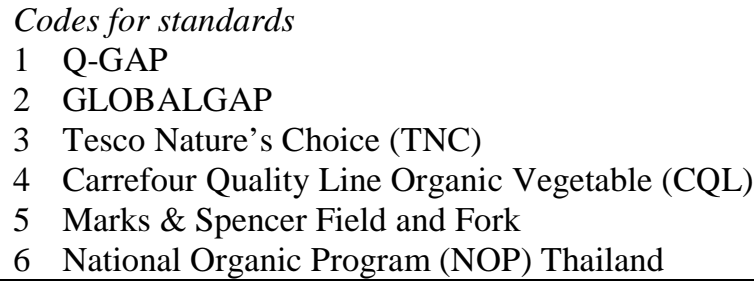

7 Organic Agriculture Certification Thailand (ACT)

8 Japanese Agricultural Standard (JAS)

9 IFOAM's Organic Guarantee System (OGS)

10 EU organic standard

11 National Organic Program (USDA)

12 Other, please specify

\begin{tabular}{|c|c|c|c|c|}
\hline \multicolumn{5}{|l|}{ Product codes } \\
\hline 1 Rice & 13 Celery & 25 Cantaloupe & 37 Acacia pennata & 47 Rose apple \\
\hline 2 Maize & 14 Yard long bean & 26 Mangosteen & (cha om) & 48 Parkia speciosa \\
\hline 3 Cassava & 15 Chinese & 27 Lychee & 38 Houttuynia (giap) & 49 Castanopsis \\
\hline 4 Para rubber & convolvus & 28 Longgong & 39 Red leaf lettuce & siamensis \\
\hline $5 \quad$ Oil palm & 16 Green okra & 29 Water melon & 40 Taro & 50 Shallot \\
\hline 6 Spring onion & 17 Chili & 30 Banana & 41 Coffee & 51 Onion \\
\hline 7 Sweet basil & 18 Asparagus & 31 Durian & 42 Betel nut & 52 Cucumber \\
\hline 8 Holy basil & 19 Chinese kale & 32 Grape & 43 Fingerroot & 53 Cantonese \\
\hline 9 Hairy basil & 20 Wattle & 33 Guava & 44 Marian plum & vegetable \\
\hline 10 Coriander & 21 Sugar cane & 34 Rambutan & 45 Lemon & 54 Lemon grass \\
\hline 11 Egg plant & 22 Papaya & 35 Coconut & 46 Santol tropical & 55 Other (specify) \\
\hline 12 Baby corn & $\begin{array}{l}23 \text { Dragon fruit } \\
24 \text { Mango }\end{array}$ & 36 Longan & fruit & \\
\hline
\end{tabular}

\section{Agreements with buyers (C13):}

Code 1: Agreements

o No fixed agreement: no fixed agreement exists if the farmer and the buyer do not agree about details e.g. concerning the production process, the amount sold, prices etc. before the exchange is made.

1 Oral agreement: An oral agreement exists if the farmer and buyer have agreed verbally about details e.g. concerning the production process, the amount sold, prices etc. before the exchange is made.

2 Written agreement: A written agreement exists if the farmer and buyer have agreed in a written contract about details e.g. concerning the production process, the amount sold, prices etc. before the exchange is made.

Code 2 (Let the farmer answer and choose the code yourself. If necessary, read the choices out loud)

\begin{tabular}{|llllll|}
\hline 1 & Arrangement lasts one season & 3 & Arrangement lasts 2 years & 5 & Arrangement lasts until buyer or I end it \\
2 & Arrangement lasts 1 year & 4 & Arrangement lasts 3 years & 6 & Other, please specify \\
\hline
\end{tabular}

Code 3 (Read the choices out loud and list applicable)

1 He pays the whole amount in cash before/at harvest

2 He pays the whole amount in cash when I deliver the product

3 He pays the whole amount in cash after I delivered the product, please specify how long after delivery

$\begin{array}{ll}4 & \text { The buyer pays every ...... days } \\ 5 & \text { The buyer pays every ...... weeks } \\ 6 & \text { He pays in cash and splits up the payment in several } \\ & \text { times } \\ 7 & \text { He pays the whole amount in kind } \\ 8 & \text { Other, please specify }\end{array}$

Code 4 (Read the choices out loud and list applicable)

0 No, he doesn't deliver anything

1 Yes, he delivers chemicals

2 Yes, he delivers fertilizer

3 Yes, he delivers seeds. Please specify

4 Yes, he delivers, please specify

5 Other, please specify

Code 5 (Read the choices out loud and list applicable)

1 Payback in cash when inputs are given

2 Payback in cash at time of harvest/delivery

3 Payback in kind at time of harvest/delivery

4 Other, please specify

Code 6 (Read the choices out loud and list applicable)

1 The buyer comes to harvest

2 Harvested and packed in wholesale units

3 Harvested, washed and packed in wholesale units

4 Harvested and packed in retail units

5 Harvested, washed and packed in retail units

6 Harvested, washed, sliced and packed in retail units

7 Other, please specify 